UNIVERSIDADE DE SÃO PAULO

FACULDADE DE ECONOMIA, ADMINISTRAÇÃO E CONTABILIDADE DEPARTAMENTO DE ADMINISTRAÇÃO PROGRAMA DE PÓS-GRADUAÇÃO EM ADMINISTRAÇÃo

\title{
A Qualidade de Vida no Trabalho dos professores de inglês: aplicação dos modelos de análise biopsicossocial e de competência do bem-estar organizacional
}

\section{Andréa Yumi Sugishita Kanikadan \\ Orientadora: Ana Cristina Limongi-França}


Prof. Dr. Adolpho Jose Melfi

Reitor da Universidade de São Paulo

Profa. Dra. Maria Tereza Leme Fleury

Diretora da Faculdade de Economia, Administração e Contabilidade

Prof. Dr. Eduardo Pinheiro Gondin de Vasconcellos

Chefe do Departamento de Administração

Prof. Dr. Isak Kruglianskas

Coordenador da Pós-Graduação em Administração 
UNIVERSIDADE DE SÃO PAULO

FACULDADE DE ECONOMIA, ADMINISTRAÇÃO E CONTABILIDADE DEPARTAMENTO DE ADMINISTRAÇÃO PROGRAMA DE PÓS-GRADUAÇÃo EM ADMINISTRAÇÃO

\section{A Qualidade de Vida no Trabalho dos professores de inglês: aplicação dos modelos de análise biopsicossocial e de competência do bem-estar organizacional}

\section{Andréa Yumi Sugishita Kanikadan}

Orientadora: Ana Cristina Limongi-França

Dissertação de Mestrado apresentada ao Departamento de Administração da Faculdade de Economia, Administração e Contabilidade da Universidade de São Paulo como requisito parcial para a obtenção do título de mestre em Administração.

São Paulo

2005 


\section{FICHA CATALOGRÁFICA}

Elaborada pela Seção de Processamento Técnico do SBD/FEA/USP

Kanikadan, Andréa Yumi Sugishita

A qualidade de vida no trabalho dos professores de inglês: aplicação dos modelos de análise biopsicossocial e de competência do bem-estar organizacional

/ Andréa Yumi Sugishita Kanikadan. -- São Paulo, 2005.

$184 \mathrm{p}$.

Dissertação (Mestrado) - Universidade de São Paulo, 2005

Bibliografia.

1. Administração da qualidade 2. Qualidade de vida no trabalho

3. Administração de recursos humanos 4. Condição de trabalho 5. Professores

I. Universidade de São Paulo. Faculdade de Economia, Administração e

Contabilidade da USP II. Título.

CDD -658.562 
“(...) Quantos séculos talvez tenham decorrido antes de chegarem os homens à altura de ver outro fogo que não o do céu! Quantos acasos não lhes foram necessários para aprender os usos mais comuns desse elemento! Quantas vezes não deixaram que ele se extinguisse antes de ter adquirido a arte de reproduzi-lo! E quantas vezes, talvez, cada um desses segredos não morreu com aquele que o descobrira!" (Rousseau, 2000; p.67)

Aos meus pais, Paulo e Hideko, que sempre apoiaram todas as minhas lutas e estiveram presentes em todas as minhas conquistas; vocês estão se tornando mestres junto comigo!

Às minhas irmãs, Paula e Vivi, por compartilhar idéias que só reforçaram a realização deste trabalho.

E àqueles que lutam por um mundo melhor e encontram sentido naquilo que fazem. 


\section{Agradecimentos}

Este capítulo é dedicado aos agradecimentos a todas aquelas pessoas que participaram desta dissertação, direta ou indiretamente, seja contribuindo para que a mesma se viabilizasse, seja nos momentos em que ela nunca foi mencionada.

Inicialmente o agradecimento é à minha orientadora e professora Ana Cristina Limongi-França, que desde o início me fez acreditar neste trabalho, e mais ainda, que todo sonho é possível à medida que batalhamos para realizá-lo. Além da orientadora, destaco também a grande amiga que esteve presente nos momentos de descontração do curso.

Aos colegas, Rogério Tadeu da Silva, que me deu dicas preciosas para entrar no curso, e a Liliana Vasconcellos Jacobsonh, hoje quase doutora, e quem me ensinou os primeiros passos da vida acadêmica, sem essas contribuições, eu não estaria aqui.

Aos eternos amigos, Felipe Figueiredo, Ricardo Wang (Jibil), Ana Paula Miyoshi, Paula Cristine Yamada, Cintia Inamassu e Patrícia Asanuma, que nunca imaginaram que eu estaria aqui, na FEA novamente, depois de ter cursado a graduação.

Ao Manoel Galdino Neto, que juntamente com minha irmã Paula tornam minha vida mais interessante e cada dia mais me mostram que é possível viver feliz em São Paulo.

Aos novos amigos, Rosalina e Carlos Tavares, pela ajuda disponibilizada no final do trabalho com a estatística, muito obrigada por todo o ensinamento acadêmico e de vida, obtidos nesses dois anos, na faculdade e nos bares da vida. Que o nosso contato seja o mais duradouro possível e chegue até Cabo Verde!

Ao meu amigo Renato Gomes pela ajuda na elaboração das planilhas em Excel e na obtenção dos dados sobre Educação, além do fato de ser um praticante da qualidade de vida fora do trabalho. 
Aos colegas do curso, Caio Vianna, Mario Nei e Renata Schirrmeister, por compartilhar muitos momentos durante o curso.

Ao colega Marcelo Miyazaki que me auxiliou na construção do instrumento de pesquisa e forneceu dicas preciosas para a conclusão do trabalho.

Ao Luiz Silva dos Santos, pela ajuda na utilização do programa SPSS.

À Maria Ângela Abduch, minha grande companheira dos esportes, que me incentivou e abriu portas ao exercício profissional da carreira acadêmica, além da experiência de vida que me acrescenta muito sempre.

Ao Wanderley Pires, meu amigo dos mais variados assuntos e meu grande exemplo de Qualidade de Vida no Trabalho.

À Clarissa Kera, por dividir durante um período as despesas da casa e a sala, é meu exemplo de dedicação ao que faz.

À Editora SBS, representada por Susanna Florissi, que divulgou a pesquisa por meio de seu informativo mensal.

Ao Braz-Tesol por ter auxiliado na divulgação da pesquisa.

Aos professores de inglês, que apesar de suas agendas lotadas, conceberam os resultados desse trabalho.

Aos professores Antonio Carlos Aidar Sauaia e Ligia Fonseca Ferreira pelas contribuições e sugestões oferecidas no exame de qualificação.

Ao professor Joel de Sousa Dutra e a todos os professores da área de Gestão de Pessoas pela oportunidade de participar do PROGEP e aprender muito sobre a vida acadêmica.

A Vilma Caseiro e toda a equipe do PROGEP por entender a minha ausência no período de conclusão deste trabalho. 
Ao estagiário Daniel Yamamoto, que me permitiu ensinar-lhe um pouco do que já vivi, que ele incorpore um pouco os conceitos de QVT em sua vida profissional.

E a todos aqueles que por falta de espaço e memória não menciono neste trabalho, mas que sabem que às suas maneiras, contribuíram para essa realização. 


\section{Resumo}

Este estudo tem como objetivo geral identificar as percepções de qualidade de vida no trabalho de professores de inglês utilizando-se o modelo de competências para a Gestão de Qualidade de Vida no Trabalho e a Abordagem Biopsicossocial.

Foi realizado um estudo exploratório descritivo, com a idéia de tornar o fenômeno em questão familiar. O trabalho caracterizou-se como descritivo, buscando, desta maneira, identificar as variáveis que determinam os critérios de Qualidade de Vida no Trabalho na percepção dos professores. Foi utilizada a pesquisa survey, que pode ser descrita como a obtenção de dados sobre características, ações ou opiniões de determinado grupo de pessoas, por meio de um questionário. Os respondentes da pesquisa foram 91 professores de inglês, compondo uma amostra não-probabilística.

Os resultados mostraram que esses professores percebem a qualidade de vida no trabalho de forma positiva, encontrando deficiência nas questões de saúde e carreira.

Concluiu-se que, embora os professores de inglês demonstrem uma percepção positiva dos itens de qualidade de vida no trabalho, os resultados refletem a necessidade que as organizações têm em possuir estratégias bem definidas, pois a gestão de pessoas é prejudicada quando isso não ocorre, trazendo conseqüências no longo prazo por ações que são tomadas no curto prazo, ou seja, a gestão de carreira deve ser tratada de forma estratégica, pois a sua ausência tem afetado parte do processo de ensino, prejudicando a saúde do profissional.

Palavras-chave: Gestão da Qualidade de Vida no Trabalho; Gestão de Pessoas; Condições de Trabalho; Professores de Inglês. 


\section{Abstract}

The study investigated the perceptions of Quality of Working Life in the English teacher's activities, based on the competency model for the Quality of Working Life and the Biopsychosocial Approach.

It was conducted an exploratory and descriptive study, so that new ideas could be discovered through this investigation. The method chosen was the survey research, getting data about characteristics, actions and opinions within a group of people, using a questionnaire. Ninety-one English teachers attended this survey, representing a nonprobabilistic sample.

The results showed that these teachers perceive positively the quality of working life, having problems in health and career matters.

It was concluded that, although the English teachers demonstrate a positive perception in the quality of working life items, the results reflect the need organizations have in establishing strategies. When it doesn't happen, it is harmful to People Management, bringing consequences in the long term. The lack of a career plan has affected part of the teaching process, causing physical diseases to the professional mentioned.

Key-words: Quality of Working Life Management; Human Resources Management; Work Conditions; English teachers; Teachers. 


\section{SUMÁRIO}

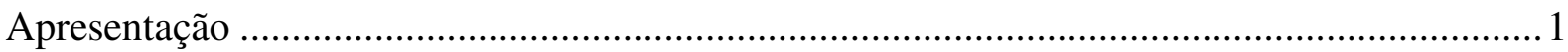

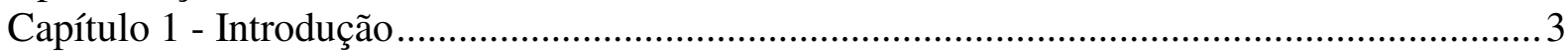

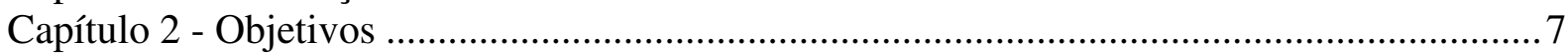

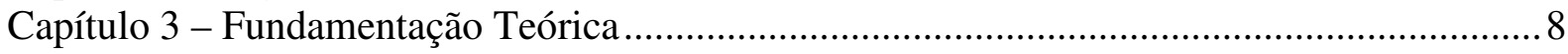

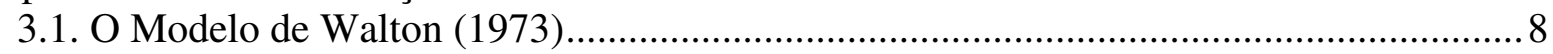

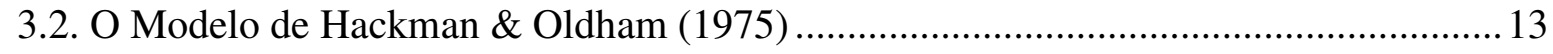

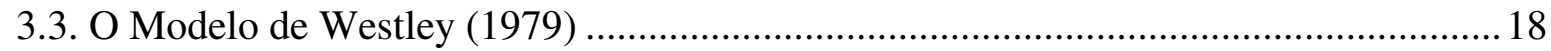

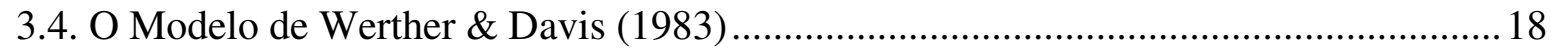

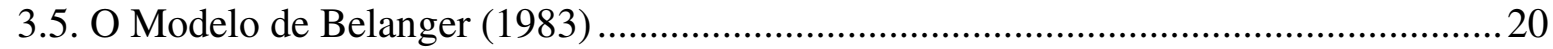

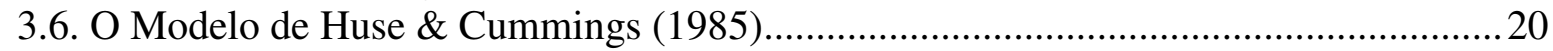

3.7. O Modelo conceitual de competências para a Qualidade de Vida no Trabalho............ 21

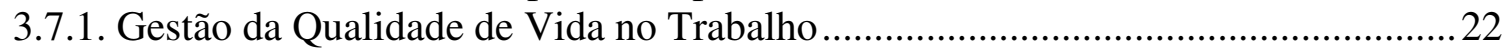

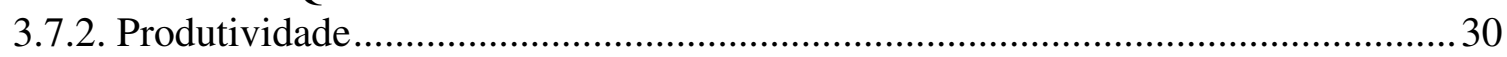

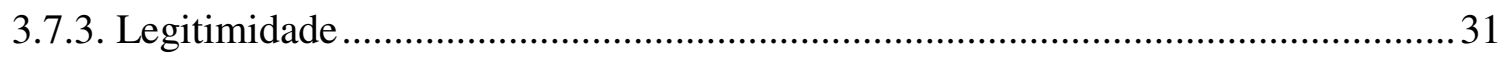

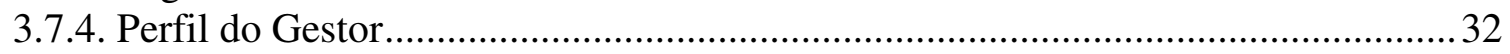

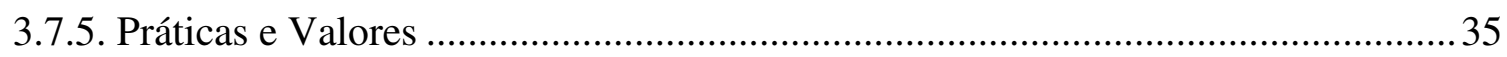

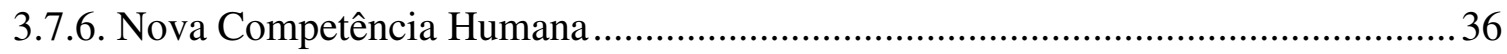

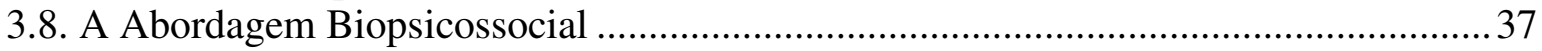

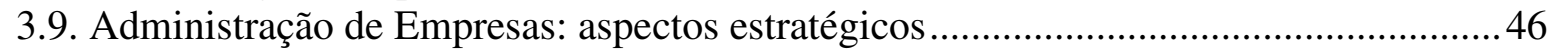

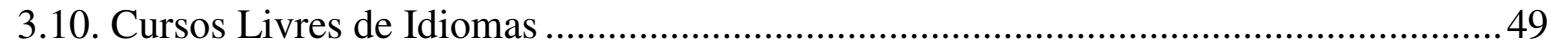

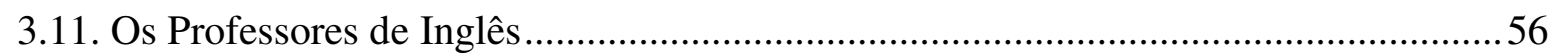

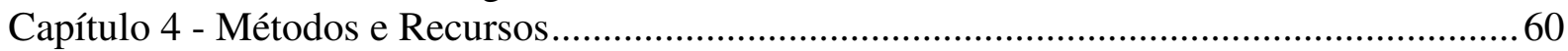

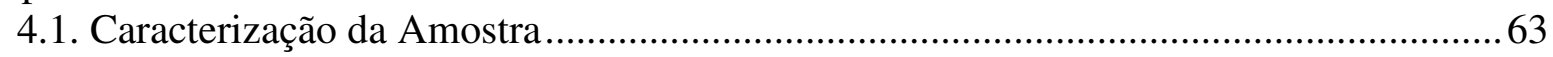

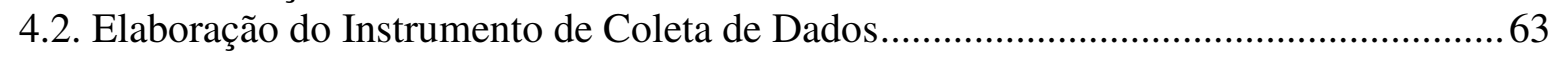

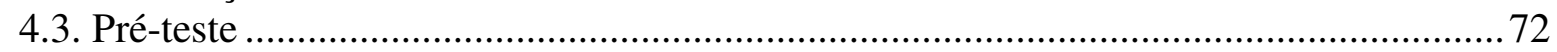

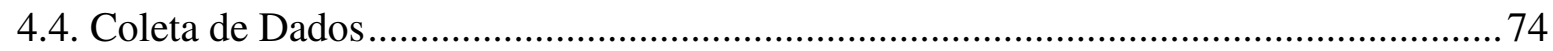

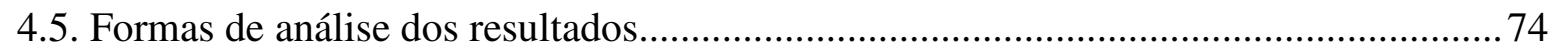

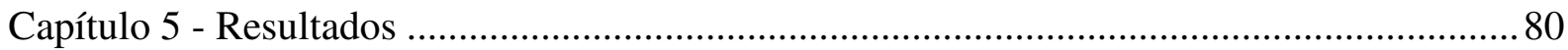

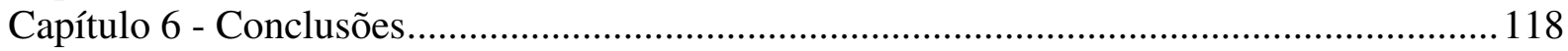

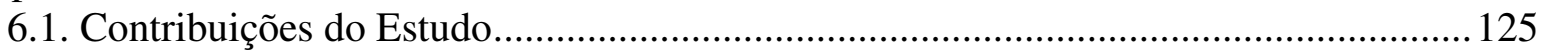

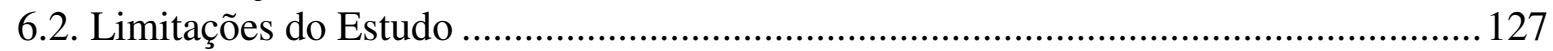

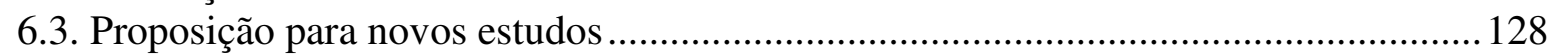

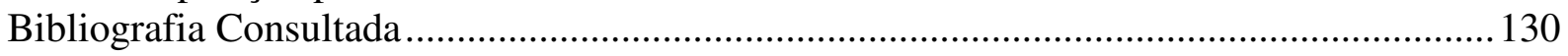

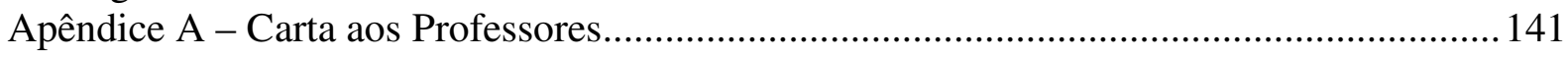

Apêndice B - Questionário .......................................................................................... 142

Apêndice C - Resultados dos demais questionários que não compuseram a amostra............ 145

Anexo A - Cursos de Graduação por número de matrícula e concluintes ............................. 165 


\section{Lista de Quadros}

Quadro 3.1 - Publicações realizadas dentro do modelo de Walton (1973) entre os anos 2000 e 2005

Quadro 3.2 - Publicações realizadas dentro do modelo de Hackman \& Oldham (1975) entre os anos 2000 e 2005

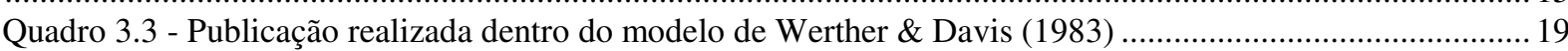

Quadro 3.4 - Resumo dos Modelos Teóricos de Qualidade de Vida no Trabalho ...........................................2 21

Quadro 3.5 - Publicações realizadas sobre Qualidade de Vida no Trabalho entre os anos 2000 e 2005 ..............25

Quadro 3.6 - Sintomas do assédio moral na saúde $(\mathrm{n}=870)$.......................................................................41

Quadro 3.7 - Variáveis qualitativas sobre o conceito de qualidade de vida no trabalho .....................................46

Quadro 3.8 - Modelo de competências para a QVT x Abordagem BPSO-96..............................................46

Quadro 4.1- Definição do conceito de QVT sob os aspectos BPSO-96 ....................................................65

Quadro 4.2- Idéias geradas a partir do exercício proposto ...........................................................................65

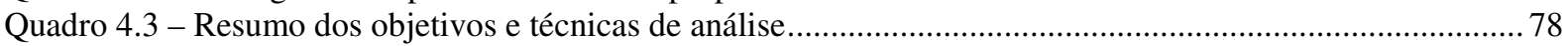

Quadro 5.1 - Classificação por formação acadêmica: graduação ……........................................................ 82

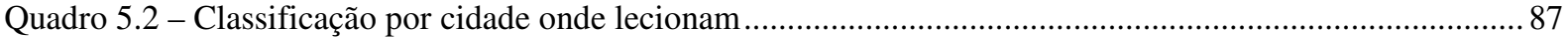

Quadro 5.3 - Análise das associações e correlação de postos, utilizando o coeficiente Spearman .................... 115

Quadro 5.4 - Nível descritivo do coeficiente de Spearman entre as questões ................................................... 116

Quadro 5.5 - Análise das associações e correlação de postos, utilizando o coeficiente Spearman ..................... 116

Quadro 5.6 - Nível descritivo do coeficiente de Spearman entre as questões .......................................... 117 


\section{Lista de Tabelas}

Tabela 3.1 - Valor aproximado de um curso de Inglês na cidade de São Paulo ...............................................51

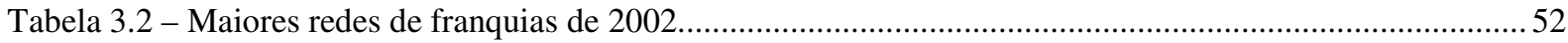

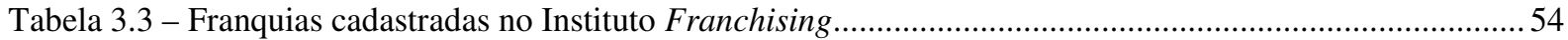

Tabela 3.4- Comparativo dos segmentos de atividade em Serviços (dez/97 e dez/99) ..................................55

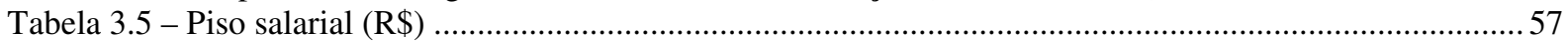

Tabela 5.1 - Classificação por Estado Civil: distribuição de freqüência..................................................... 83

Tabela 5.2 - Classificação por faixa salarial: distribuição de freqüência ..................................................... 83

Tabela 5.3 - Classificação por número de dependentes: distribuição de frequiência.........................................84

Tabela 5.4 - Classificação por Local de aprendizado do idioma: distribuição de frequiência .............................85

Tabela 5.5 - Classificação por Tempo: distribuição de freqüência ............................................................. 86

Tabela 5.6 - Distribuição de freqüência: professores que possuem outra ocupação ....................................... 87

Tabela 5.7 - Distribuição de freqüência das cidades que os respondentes lecionam .........................................8 88

Tabela 5.8 - Distribuição de freqüência da associação a alguma entidade ....................................................8 88

Tabela 5.9 - Medidas de posição e dispersão das variáveis integrantes do Conceito de QVT............................92

Tabela 5.10 - Medidas de posição e dispersão das variáveis integrantes do fator crítico Produtividade ..............97

Tabela 5.11 - Medidas de posição e dispersão das variáveis integrantes do fator crítico Legitimidade ............. 102

Tabela 5.12 - Medidas de posição e dispersão das variáveis integrantes do fator crítico Perfil do Gestor......... 105

Tabela 5.13 - Medidas de posição e dispersão das variáveis integrantes do fator crítico Práticas e Valores...... 108

Tabela 5.14 - Medidas de posição e dispersão das variáveis integrantes do fator crítico Nova Competência.... 112

Tabela 7.1 - Perfil da amostra de professores do Ensino Infantil e Fundamental........................................... 145

Tabela 7.2 - Classificação por tempo de profissão dos professores do Ensino Infantil e Fundamental .............. 145

Tabela 7.3 - Classificação por Idade dos professores do Ensino Infantil e Fundamental .................................146

Tabela 7.4 - Classificação por Sexo dos professores do Ensino Infantil e Fundamental ................................. 146

Tabela 7.5 - Classificação por Número de Dependentes dos professores do Ensino Infantil e Fundamental..... 146

Tabela 7.6 - Classificação por Estado Civil dos professores do Ensino Infantil e Fundamental .......................147

Tabela 7.7 - Classificação por Faixa Salarial dos professores do Ensino Infantil e Fundamental ..................... 147

Tabela 7.8 - Percentual de professores do Ensino Infantil e Fundamental que possuem outra ocupação........... 147

Tabela 7.9 - Classificação por Local de aprendizado do idioma dos professores do Ensino Infantil e Fundamental

148

Tabela 7.10 - Classificação por cidade onde os professores do Ensino Infantil e Fundamental lecionam ......... 148 Tabela 7.11 - Distribuição de Freqüência dos professores de Ensino Infantil e Fundamental que fazem parte de

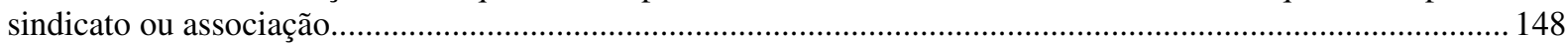

Tabela 7.12 - Classificação por Escolaridade dos Professores do Ensino Infantil e Fundamental .................... 149

Tabela 7.13 - Medidas de Posição e dispersão das questões 1 a 22 dos professores do Ensino Infantil e

Fundamental

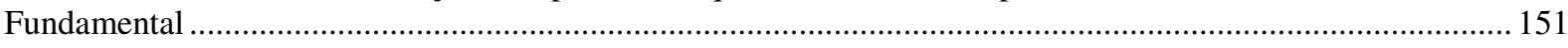

Tabela 7.15 - Perfil da amostra de professores do Ensino Médio............................................................... 152

Tabela 7.16 - Classificação por tempo de profissão dos professores do Ensino Médio ..................................... 152

Tabela 7.17 - Classificação por Idade dos professores do Ensino Médio .........................................................153

Tabela 7.18 - Classificação por Sexo dos professores do Ensino Médio....................................................... 153

Tabela 7.19 - Classificação por Número de Dependentes dos professores do Ensino Médio ........................... 153

Tabela 7.20 - Classificação por Estado Civil dos professores do Ensino Médio ............................................... 153

Tabela 7.21- Classificação por Faixa Salarial dos professores do Ensino Médio............................................ 154

Tabela 7.22 - Percentual de professores do Ensino Médio que possuem outra ocupação ................................. 154

Tabela 7.23 - Classificação por Local de aprendizado do idioma dos professores do Ensino Médio................. 154

Tabela 7.24 - Classificação por cidade onde os professores do Ensino Médio lecionam ................................... 155

Tabela 7.25 - Distribuição de Freqüência dos professores de Ensino Médio que fazem parte de sindicato ou

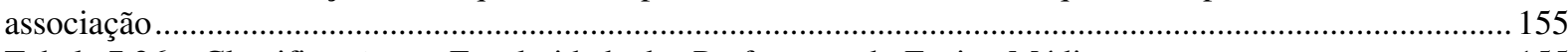

Tabela 7.26 - Classificação por Escolaridade dos Professores do Ensino Médio ............................................. 155

Tabela 7.27 - Medidas de posição e dispersão das questões 1 a 22 dos professores do Ensino Médio .............. 156

Tabela 7.28 - Medidas de posição e dispersão das questões 23 a 45 dos professores do Ensino Médio ............ 157

Tabela 7.29 - Perfil da amostra de professores do Ensino Superior .................................................................. 158

Tabela 7.30 - Classificação por tempo de profissão dos professores do Ensino Superior ................................ 158

Tabela 7.31 - Classificação por Idade dos professores do Ensino Superior...................................................... 159

Tabela 7.32 - Classificação por Sexo dos professores do Ensino Superior ......................................................159

Tabela 7.33 - Classificação por Número de Dependentes dos professores do Ensino Superior .........................159

Tabela 7.34 - Classificação por Estado Civil dos professores do Ensino Superior........................................ 160 
Tabela 7.35 - Classificação por Faixa Salarial dos professores do Ensino Superior

Tabela 7.36 - Percentual de professores do Ensino Superior que possuem outra ocupação .............................. 160

Tabela 7.37 - Classificação por Local de aprendizado do idioma dos professores do Ensino Superior ............. 161

Tabela 7.38 - Classificação por cidade onde os professores do Ensino Superior lecionam............................... 161

Tabela 7.39 - Distribuição de Frequiência dos professores de Ensino Superior que fazem parte de sindicato ou associação

Tabela 7.40 - Classificação por Escolaridade dos Professores do Ensino Superior........................................... 162

Tabela 7.41 - Medidas de posição e dispersão das questões 1 a 22 dos professores do Ensino Superior ........... 163

Tabela 7.42 - Medidas de posição e dispersão das questões 1 a 22 dos professores do Ensino Superior 


\section{Lista de Gráficos}

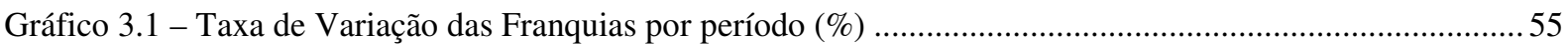

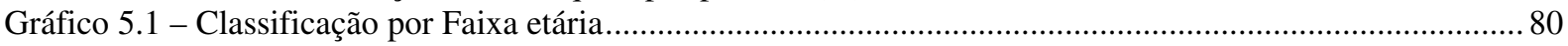

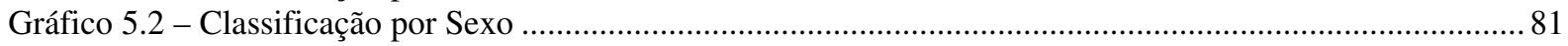

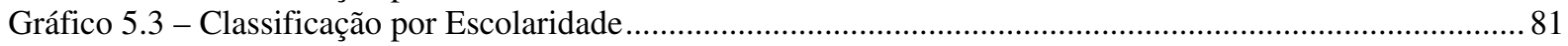

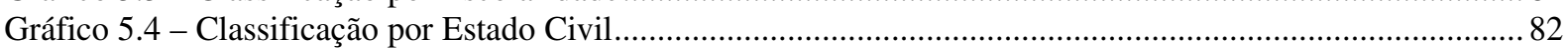

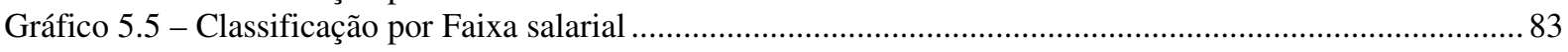

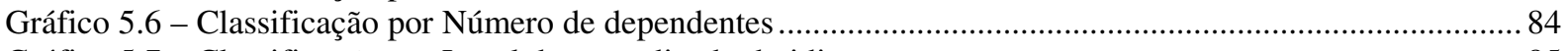

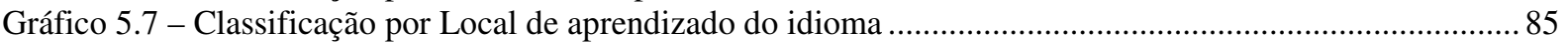

Gráfico 5.8 - Classificação por Tempo (anos) que exercem a profissão......................................................85

Gráfico 5.9 - Percentual de professores que possuem outra ocupação …...................................................... 86

Gráfico 5.10 - Respondentes que lecionam em São Paulo..................................................................... 87

Gráfico 5.11 - Professores que estão vinculados a algum sindicato ou associação ......................................... 88

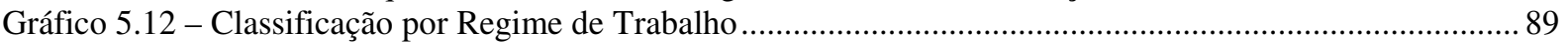

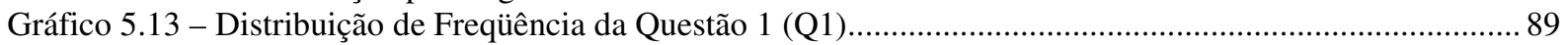

Gráfico 5.14 - Distribuição de Freqüência da Questão 2 (Q2) .................................................................... 89

Gráfico 5.15 - Distribuição de Freqüência da Questão 3 (Q3) ....................................................................90

Gráfico 5.16 - Distribuição de Freqüência da Questão 4 (Q4) ...................................................................90

Gráfico 5.17 - Distribuição de Frequiência da Questão 5 (Q5) ......................................................................90

Gráfico 5.18 - Distribuição de Freqüência da Questão 6 (Q6) .................................................................... 91

Gráfico 5.19 - Distribuição de Freqüência da Questão 7 (Q7) .................................................................91

Gráfico 5.20 - Distribuição de Freqüência da Questão 8 (Q8) .....................................................................91

Gráfico 5.21 - Distribuição de Freqüência do Fator Crítico - Conceito de QVT .............................................92

Gráfico 5.22 - Distribuição de Freqüência da Questão 9 (Q9)......................................................................93

Gráfico 5.23 - Distribuição de Freqüência da Questão 10 (Q10) ................................................................93

Gráfico 5.24 - Distribuição de Freqüência da Questão 11 (Q11) ................................................................94

Gráfico 5.25 - Distribuição de Freqüência da Questão 12 (Q12)..................................................................94

Gráfico 5.26 - Distribuição de Freqüência da Questão 13 (Q13) ...................................................................94

Gráfico 5.27 - Distribuição de Freqüência da Questão 14 (Q14) ...................................................................95

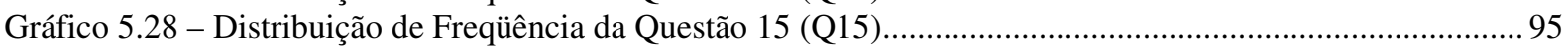

Gráfico 5.29 - Distribuição de Freqüência da Questão 16 (Q16)..................................................................95

Gráfico 5.30 - Distribuição de Freqüência da Questão 17 (Q17) ..................................................................96

Gráfico 5.31 - Distribuição de Freqüência da Questão 18 (Q18) ..................................................................96

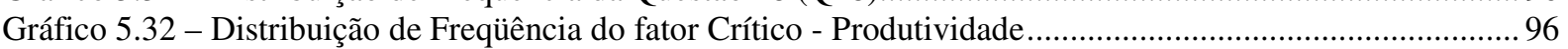

Gráfico 5.33 - Distribuição de Freqüência da Questão 19 (Q19) ....................................................................98

Gráfico 5.34 - Distribuição de Freqüência da Questão 20 (Q20) ..................................................................98

Gráfico 5.35 - Distribuição de Freqüência da Questão 21 (Q21) ................................................................98

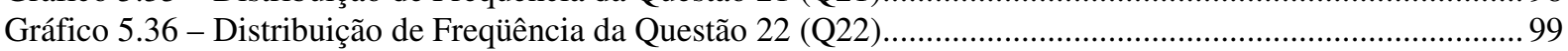

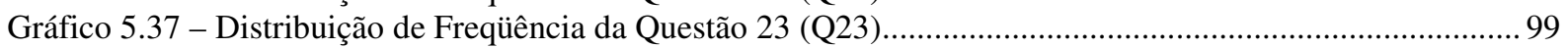

Gráfico 5.38 - Distribuição de Freqüência da Questão 24 (Q24) ..................................................................99

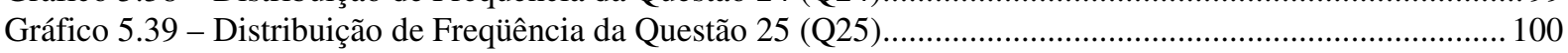

Gráfico 5.40 - Distribuição de Frequiência da Questão 26 (Q26).................................................................. 100

Gráfico 5.41 - Distribuição de Freqüência da Questão 27 (Q27) ................................................................. 100

Gráfico 5.42 - Distribuição de Freqüência do Fator Crítico - Legitimidade ................................................. 101

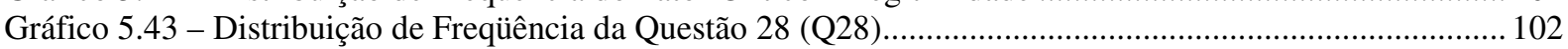

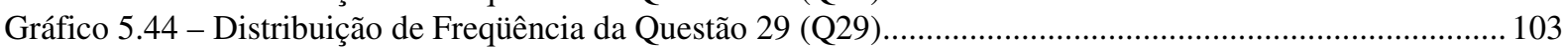

Gráfico 5.45 - Distribuição de Freqüência da Questão 30 (Q30)................................................................ 103

Gráfico 5.46 - Distribuição de Freqüência da Questão 31 (Q31) ................................................................103

Gráfico 5.47 - Distribuição de Freqüência da Questão 32 (Q32) ................................................................... 104

Gráfico 5.48 - Distribuição de Frequiência da Questão 33 (Q33) .................................................................. 104

Gráfico 5.49 - Distribuição de Frequiência do Fator Crítico - Perfil do Gestor ................................................. 104

Gráfico 5.50 - Distribuição de Freqüência da Questão 34 (Q34) ................................................................ 106

Gráfico 5.51 - Distribuição de Freqüência da Questão 35 (Q35) ..................................................................... 106

Gráfico 5.52 - Distribuição de Frequiência da Questão 36 (Q36).................................................................. 106

Gráfico 5.53 - Distribuição de Freqüência da Questão 37 (Q37) ................................................................. 107

Gráfico 5.54 - Distribuição de Freqüência da Questão 38 (Q38) ................................................................ 107

Gráfico 5.55 - Distribuição de Frequiência da Questão 39 (Q39)................................................................. 107

Gráfico 5.56 - Distribuição de Frequiência do Fator Crítico - Práticas e Valores............................................. 108

Gráfico 5.57 - Distribuição de Freqüência da Questão 40 (Q40) ................................................................ 109

Gráfico 5.58 - Distribuição de Freqüência da Questão 41 (Q41) ............................................................. 109 
Gráfico 5.59 - Distribuição de Freqüência da Questão 42 (Q42).

Gráfico 5.60 - Distribuição de Frequiência da Questão 43 (Q43).

110

Gráfico 5.61 - Distribuição de Freqüência da Questão 44 (Q44).

110

Gráfico 5.62 - Distribuição de Freqüência da Questão 45 (Q45).

111

Gráfico 5.63 - Distribuição de Freqüência do Fator Crítico - Nova Competência... 


\section{Lista de Abreviações}

- QVT: Qualidade de Vida no Trabalho

- GQVT: Gestão da Qualidade de Vida no Trabalho

- BPSO-96: Abordagem Biopsicossocial

- MEC: Ministério da Educação

- SINPROSP: Sindicato dos Professores de São Paulo

- DIEESE: Departamento Intersindical de Estatística e Estudos Sócio-econômicos

- IBGE: Insituto Brasileiro de Geografia e Estatística

- CLT: Consolidação das Leis de Trabalho

- CAPES: Coordenação de Aperfeiçoamento de Pessoal de Nível Superior 
Apresentação

A escolha do tema Qualidade de Vida no Trabalho (QVT) iniciou-se com as experiências profissionais, as quais foram vividas pela autora no período compreendido entre a conclusão do curso de graduação (2000) e o ingresso no mestrado (2003). Imaginava-se que muitas empresas, especialmente as de pequeno porte, preocupavam-se pouco ou quase nada com as questões relativas à QVT. As pesquisas mostram que a realidade não está tão ruim assim, existem muitas empresas preocupadas com tais questões, o que provoca uma curiosidade maior em conhecer a realidade das empresas nos mais diversos setores e portes organizacionais, visto que grande parte dos relatos acadêmicos se refere às grandes empresas cujos programas são formalizados e apoiados financeiramente pela alta gerência (LimongiFrança, 2003). Outros pesquisadores concentram seus estudos em atividades ocupacionais, ou seja, não estudam uma organização isoladamente, mas uma determinada atividade ocupacional, dentro de uma única organização ou uma classe de forma geral (Nunes, 1999; Zavattaro, 1999; Honório et al., 2001). Além disso, tais relatos, muitas vezes partem de estudos realizados por acadêmicos de outras áreas que não seja a Administração (Pereira, 1997; Zavattaro, 1999; Souza, 2003). Isso traz a idéia de que o gestor dá pouca prioridade à gestão da QVT.

Dentro dessas considerações, ao buscar pesquisas sobre os professores em geral, encontrou-se alguns estudos que analisam os professores de ensino médio e superior (Paiva et al., 2002; Penteado, 2003), e a curiosidade aumentou mais ainda dada a breve experiência da autora nessa ocupação, tendo sido a primeira experiência vivida em 1994, durante um ano, e posteriormente em 2003, pelo mesmo período, trazendo a reflexão sobre as possibilidades da profissão, os pontos fortes e fracos de uma carreira nessa área e como gerir a qualidade de vida neste trabalho. Ao conviver com profissionais dessa área, percebeu-se que são pessoas de 
formação educacional sólida, ou seja, a grande maioria teve acesso às escolas de qualidade na educação básica, além de muitos profissionais, entre os 18 e 25 anos, já terem vivenciado experiências internacionais. Ademais, foram grandes as diferenças percebidas no mercado de trabalho que separa a primeira experiência (1994) da mais recente (2003). A partir desses pontos, o trabalho divide-se nos seguintes capítulos:

Capítulo 1 - Introdução: evolução do tema e dos profissionais pesquisados.

Capítulo 2 - Objetivos: o que se esperava atingir com o trabalho.

Capítulo 3 - Fundamentação Teórica: foram conceituados os fatores críticos que compõem o modelo conceitual de competências para a gestão da QVT, ou seja, o conceito de GQVT, Produtividade, Legitimidade, Perfil do Gestor, Práticas e Valores, e Nova Competência. A cada um desses fatores foi feita a associação com os critérios biopsicossociais e organizacionais (BPSO-96) geradores do instrumento de pesquisa. Foi descrito o papel do professor de inglês e o que é uma escola de idiomas.

Capítulo 4 - Métodos e Recursos: foi descrita a metodologia utilizada e os recursos necessários à realização do trabalho. Refere-se a um estudo exploratório, onde foi utilizado um instrumento de coleta de dados, para uma amostra aleatória não-probabilística de professores de inglês atuantes em instituições brasileiras dedicadas a este fim.

Capítulo 5 - Resultados: foram apresentados os resultados encontrados no estudo e a análise dos mesmos.

Capítulo 6 - Conclusões: atestou-se se os objetivos pretendidos foram alcançados, tecendo as considerações pertinentes.

Ao final deste estudo, encontra-se disponível a bibliografia consultada e os apêndices e anexos para eventuais consultas. 


\section{Capítulo 1 - Introdução}

A abertura de um espaço para o desenvolvimento da Qualidade de Vida no Trabalho (QVT) buscando melhorias de condições de vida e bem-estar, é consequiência da busca da produtividade e dos processos de mudança que visam o posicionamento competitivo das empresas no mercado. Devido às questões de sobrevivência necessárias às empresas, o assunto tem-se apresentado antagônico em muitos aspectos. Será que não é possível falar em QVT ao mesmo tempo em que se fala em sobrevivência? Alguns autores destacam que nem sempre implantar um programa de QVT é algo dispendioso, e somente factível em grandes empresas. Para o senso comum das pessoas, o assunto não passa de um modismo, pois as empresas capitalistas existem para fazer com que as pessoas trabalhem e gerem resultados, não importando o modo como isso possa ocorrer.

A evolução histórica dos conceitos existentes em QVT indica que não se trata de um modismo, visto que os primeiros passos foram dados no começo do século $\mathrm{XX}$ com a regulamentação do trabalho de menores, da jornada de trabalho e do descanso semanal, e das indenizações por acidentes de trabalho (Walton, 1973). Nesse contexto, nota-se que uma das primeiras ações tomadas refere-se a questões trabalhistas. Mais adiante, outros estudiosos focaram suas considerações na humanização do cargo, responsabilidade social, saúde, e dessa forma, até os dias de hoje, em que se define a QVT como algo a ser considerado de forma abrangente. Vale ressaltar que nenhuma abordagem é mais adequada que outra: a escolha do modelo conceitual deverá levar em consideração a cultura da organização (Limongi-França, 2003) que a adota, ou seja, a sua missão, e então suas políticas de QVT estarão voltadas para isso. 
Aqueles que têm se envolvido na busca constante por melhores condições de trabalho, têm presenciado um momento repleto de mudanças nas questões relacionadas ao mundo do trabalho, e neste caso destaca-se a emergência dos programas formais de QVT. Muitos dos exemplos tratados na literatura referem-se às grandes empresas, cujas ações partem de suas matrizes e possuem um caráter estruturado e formal.

Visando expandir o tema para outros portes de empresas e atividades ocupacionais diferenciadas, lança-se neste trabalho o desafio de se estudar a QVT dos professores de inglês.

Já destacavam os antigos filósofos quanto à importância da linguagem, com a transformação do homem em um animal social e cívico (Aristóteles apud Chauí, 2004). Já em 1754, Rousseau (2000) reforçava o caráter distintivo que a linguagem tem entre as nações.

Desde a década de 90, as línguas estrangeiras estão em evidência, muitas pessoas perdem oportunidades por não falarem determinados idiomas, cada vez exige-se mais; cada indivíduo que sabe um pouco mais apresenta maiores possibilidades de alcançar oportunidades de trabalho mais atraentes financeiramente. O discurso proferido pelos veículos de comunicação de massa faz com que as pessoas sintam-se na obrigação de falar mais de um idioma (Valdejão, 2004). Além disso, a linguagem exerce poder de conhecimento racional (Chauí, 2004).

Destaca-se a dificuldade que as pessoas em geral têm em aprender uma língua estrangeira, pelo nível insuficiente na formação básica, proporcionando um aumento na diversidade de métodos e cursos que a cada ano proliferam pelo país. São cada vez menores as barreiras para montar um curso de inglês ou abrir uma franquia, investindo no negócio 
próprio. A estrutura organizacional apresenta-se simples, pois, de acordo com Andrade (1993), a existência de 3 pessoas já viabilizaria a abertura de um estabelecimento. Não se leva em consideração os conhecimentos em gestão, pois o que ocorre é um investimento muito pesado em marketing, fazendo com que os interessados em aprender o inglês seduzam-se com promessas que nem sempre se tornam verdadeiras.

Observa-se nos discursos publicitários sempre a existência de qualidade no ensino dos mais variados cursos de idiomas, e grande parte deles destacam seus professores como indicador de qualidade:

"Produzir programas educacionais a fim de promover o ensino de idiomas com total qualidade e responsabilidade social, contribuindo para o desenvolvimento intelectual e cultural de alunos, professores e colaboradores" (http://www.fisk.com.br/funda01.htm, acesso em 12 mai. 2005).

"Com sua eficiente estrutura, o CCAA combina tradição e inovação para oferecer um serviço altamente qualificado a alunos, professores e franqueados de todo o Brasil" (http://www.ccaa.com.br/home/estrutura.asp, acesso em 12 mai. 2005).

"O Cel-lep investe continuamente em todos os setores: atendimento, instalações, material didático, recursos tecnológicos e, principalmente, nas pessoas que trabalham na organização" (http://www.cel-lep.com.br/, acesso em 11 mai. 2005).

“(...) saiba que o Berlitz está sempre procurando candidatos qualificados para nossos programas de idiomas e cross-cultural, e para cargos em nossa sede administrativa" (http://www.berlitz.com.br/Employment/default.htm?ISO=pt, acesso em 11 de maio de 2005). 
“(...) nossos professores são uma história a parte. Animados e dinâmicos usam uma linguagem natural, seguindo os padrões de entonação (...)" (http://www.cna.com.br/, acesso em 04/01/2003).

"Além de um ensino padronizado e de alta qualidade, o aluno estará trabalhando com atividades práticas (...)" (http://www.wizard.com.br/, acesso em 12 mai. 2005).

Por outro lado, ainda que todo o contexto leve a concordar que o profissional que domina bem um idioma, e é capaz de ensiná-lo a outras pessoas, possui importância fundamental no atual cenário, nota-se uma negligência para com tais profissionais, dado o considerável número que se forma a cada ano, seguido da grande disponibilidade de tais profissionais no mercado. Dados obtidos no Instituto Nacional de Estudos e Pesquisas Educacionais (INEP, 2004) revelam que 33.213 alunos concluíram o curso de Letras no Brasil em 2003, considerando universidades públicas e particulares. Segundo a Associação Brasileira de Franchising - ABF (2004), o número de franquias cresceu $8 \%$ em 2004, criando uma média de $8.000^{1}$ vagas para professores.

Assim, torna-se crucial levantar as questões relacionadas à qualidade de vida nesta atividade ocupacional, especialmente quando se dá o ingresso do profissional em uma determinada organização.

\footnotetext{
${ }^{1}$ Considerou-se uma média de 10 professores por unidade criada, pois não existem dados estatísticos que comprovem o fato.
} 


\section{Capítulo 2 - Objetivos}

Este trabalho teve como objetivo geral identificar as percepções de QVT dos professores de inglês utilizando-se o modelo de competências para a Gestão de Qualidade de Vida no Trabalho (GQVT) e a abordagem biopsicossocial (BPSO-96).

Pretendeu-se atingir alguns objetivos mais específicos: identificar se os indicadores de QVT guardam alguma relação com a condição sócio-econômica; as possíveis explicações para as semelhanças ou diferenças nas percepções; e os aspectos mais evidentes na abordagem biopsicossocial.

Para isso, a busca pelo objetivo iniciou-se pela fundamentação teórica. 


\section{Capítulo 3 - Fundamentação Teórica}

Visando entender o contexto no qual a pesquisa se insere, este estudo tem sua fundamentação teórica sustentada pelos modelos conceituais de QVT definidos por diversos autores, dando-se ênfase ao modelo conceitual de competências proposto por Limongi-França (2003), objeto deste trabalho. Por se tratar de uma disciplina que faz interface com diversas áreas da ciência, a QVT é objeto de muitos estudos, e muitos relatos baseiam-se apenas em programas ou práticas isoladas que são conceitos pessoais, não apresentando critérios bem definidos de metas a serem alcançadas, deixando-se de lado os modelos teóricos (Goulart \& Sampaio, 1999).

A idéia de utilizar o modelo de competências traz a necessidade de se definir os aspectos presentes na abordagem biopsicossocial (BPSO-96), dado que o ser humano é um todo complexo (Limongi-França \& Rodrigues, 2002), e um aspecto afeta o outro.

Por se tratar de um estudo em um ambiente organizacional específico, foi descrito o que é um curso de idiomas e as questões estratégicas da administração, bem como as características dos profissionais que atuam neste tipo de organização.

\subsection{O Modelo de Walton (1973)}

O modelo de Walton destaca a humanização e a responsabilidade social, e adota critérios para se entender o conceito, incluindo oito categorias que são descritas a seguir. Esse conjunto de critérios fundamenta-se na dimensão organizacional, considerando o poder da empresa. Foram definidos indicadores para facilitar a compreensão e comparação de cada critério: 
A compensação justa e adequada: refere-se à remuneração recebida dentro de padrões organizacionais baseados na cultura da empresa e em modelos ideológicos. Indicadores: salário e jornada de trabalho;

As condições de trabalho seguras e saudáveis: referem-se aos horários razoáveis, condições físicas que reduzam riscos de danos e doenças, existência de critérios que respeitem idade, estrutura física. Indicadores: ambiente físico e salubridade;

As oportunidades imediatas para desenvolver e usar as capacidades humanas: são consideradas as potencialidades, e desafio pessoal-profissional. Indicadores: autonomia, auto-estima, capacitação múltipla e informações sobre o trabalho;

As oportunidades futuras para o crescimento contínuo e a garantia de emprego: são definidas como oportunidade de carreira, através da educação formal, uso do conhecimento, das habilidades expandidas e das habilidades recém-adquiridas. Indicadores: carreira, desenvolvimento pessoal e estabilidade no emprego;

A integração social na organização: corresponde a ausência de preconceitos, de modo que se crie a comunidade na organização. Indicadores: ausência de preconceitos, habilidade social e valores comunitários;

$>$ O constitucionalismo na organização: está ligado com a noção de cidadania, envolvendo aspectos relacionados aos direitos e deveres legais dos cidadãos. Indicadores: os direitos garantidos, a privacidade e a imparcialidade; 
$>$ O trabalho e o espaço total na vida do indivíduo: englobam a valorização de outros pilares que sustentam a vida das pessoas, como suas relações com a família, lazer, interesses comunitários e religiosos. Indicadores: a liberdade de expressão, a vida pessoal preservada e os horários previsíveis;

A relevância social do trabalho: deve-se atentar às ações referentes ao meio ambiente, oportunidade de emprego, atendimento das necessidades sociais de saúde, transporte, comunicação, educação e higiene. Indicadores: imagem da empresa e responsabilidade social da empresa.

Seu estudo é muito citado nos meios acadêmicos, e o mais relevante é ainda a sua validade. 
Quadro 3.1 - Publicações realizadas dentro do modelo de Walton (1973) entre os anos 2000 e 2005

\begin{tabular}{|c|c|c|c|c|c|c|c|c|}
\hline Ano & Autor & Título & Natureza & Tema & Foco & Objetivo & $\begin{array}{l}\text { Modelo } \\
\text { Teórico }\end{array}$ & Resultados \\
\hline 2003 & SOUZA, T. M. & $\begin{array}{l}\text { O Gerenciamento no } \\
\text { Cotidiano de uma } \\
\text { Unidade de Terapia } \\
\text { Intensiva Pediátrica e } \\
\text { Neonatal e a } \\
\text { Qualidade de Vida no } \\
\text { Trabalho da Equipe } \\
\text { de Enfermagem }\end{array}$ & $\begin{array}{l}\text { Mestrado } \\
\text { Enfermagem/USP }\end{array}$ & QVT & $\begin{array}{lr}\text { Profissionais } & \text { da } \\
\text { equipe } & \text { de } \\
\text { enfermagem de uma } \\
\text { Unidade de } \\
\text { Intensiva Perapia } \\
\text { Neonatal. }\end{array}$ & $\begin{array}{l}\text { Conhecer as situações do } \\
\text { cotidiano de trabalho que } \\
\text { interferiam na QVT dos } \\
\text { profissionais da equipe de } \\
\text { enfermagem; conhecer o } \\
\text { conceito atribuído à QVT e } \\
\text { identificar as atividades ou } \\
\text { estratégias que possibilitariam } \\
\text { mudanças nas situações que } \\
\text { dificultam o trabalho destes } \\
\text { profissionais. }\end{array}$ & $\begin{array}{l}\text { Walton } \\
\text { (1973) }\end{array}$ & $\begin{array}{l}\text { Foram formuladas estratégias } \\
\text { para enfrentar as situações, } \\
\text { considerando a governabilidade } \\
\text { individual e institucional, como } \\
\text { aprender a trabalhar com as } \\
\text { diferenças, estreitar as relações } \\
\text { interpessoais com a chefia e } \\
\text { criar oportunidades para } \\
\text { desenvolver atividades com os } \\
\text { familiares, conhecendo } \\
\text { limitações e possibilidades. }\end{array}$ \\
\hline 2002 & $\begin{array}{l}\text { HONORIO, D. } \\
\text { E. }\end{array}$ & $\begin{array}{lr}\text { A Qualidade de Vida } \\
\text { do Operário da } \\
\text { Construção Civil e } \\
\text { sua Importância na } \\
\text { Qualidade r } \\
\text { Produtividade } \\
\text { Obras } & \text { em } \\
\end{array}$ & $\begin{array}{l}\text { Mestrado } \\
\text { PPGEP/UFSC }\end{array}$ & $\begin{array}{l}\text { QVT, } \\
\text { qualidade e } \\
\text { produtividade }\end{array}$ & $\begin{array}{l}\text { Operários de indústria } \\
\text { de edificações }\end{array}$ & $\begin{array}{l}\text { Conhecer os fatores } \\
\text { determinantes da QVT dos } \\
\text { operários que atuam na } \\
\text { indústria de edificações e a } \\
\text { sua influência na qualidade e } \\
\text { produtividade dos bens e } \\
\text { serviços por eles gerados. }\end{array}$ & $\begin{array}{l}\text { Walton } \\
\text { (1973) }\end{array}$ & $\begin{array}{l}\text { Constatou-se a necessidade de } \\
\text { se investir numa maior } \\
\text { conscientização do conceito de } \\
\text { QVT, como medida em longo } \\
\text { prazo. Permitiu identificar os } \\
\text { indicadores da QVT que } \\
\text { apresentam baixo índice de } \\
\text { satisfação por parte dos } \\
\text { operários de obras que são } \\
\text { considerados pelos gerentes } \\
\text { como cruciais para um melhor } \\
\text { desempenho no trabalho. }\end{array}$ \\
\hline 2002 & $\begin{array}{l}\text { ROMANZINI, C. } \\
\text { D. }\end{array}$ & $\begin{array}{l}\text { Qualidade de Vida no } \\
\text { Trabalho em Duas } \\
\text { Empresas } \\
\text { Prestadoras de } \\
\text { Serviço de Acesso à } \\
\text { Internet na Região de } \\
\text { Caxias do Sul }\end{array}$ & $\begin{array}{l}\text { Mestrado } \\
\text { Interinstitucional } \\
\text { PPGA - UCS }\end{array}$ & $\begin{array}{ll}\text { QVT } & \mathrm{e} \\
\text { Informática }\end{array}$ & $\begin{array}{l}\text { Funcionários de dois } \\
\text { provedores de acesso } \\
\text { à internet na região } \\
\text { de Caxias do Sul. }\end{array}$ & $\begin{array}{l}\text { Identificar como os integrantes } \\
\text { de dois provedores de acesso } \\
\text { à internet percebem a } \\
\text { qualidade de vida no trabalho } \\
\text { em seu ambiente profissional. }\end{array}$ & $\begin{array}{l}\text { Walton } \\
\text { (1973) }\end{array}$ & $\begin{array}{l}\text { Verificou-se que vários fatores } \\
\text { negativos estão agindo sobre o } \\
\text { indivíduo, afetando a qualidade } \\
\text { de vida do trabalhador no seu } \\
\text { ambiente de trabalho. Foram } \\
\text { detectados agentes estressores, } \\
\text { que atuam de forma negativa } \\
\text { sobre os indivíduos, além da } \\
\text { deficiência em alguns fatores } \\
\text { ergonômicos. }\end{array}$ \\
\hline 2001 & DETONI, D. J. & $\begin{array}{l}\text { Estratégias de } \\
\text { avaliação da QVT: um } \\
\text { estudo de caso em } \\
\text { agroindústrias }\end{array}$ & $\begin{array}{l}\text { Mestrado - } \\
\text { PPGEP/ } \\
\text { UFSC }\end{array}$ & $\begin{array}{l}\text { Avaliação da } \\
\text { QVT }\end{array}$ & $\begin{array}{l}\text { Trabalhadores da } \\
\text { área de produção em } \\
\text { quatro agroindústrias } \\
\text { de rações para } \\
\text { animais pertencentes } \\
\text { ao segmento } \\
\text { cooperativista do } \\
\text { extremo oeste do } \\
\text { Estado do Paraná. }\end{array}$ & $\begin{array}{l}\text { Como os trabalhadores } \\
\text { percebem e qual a satisfação } \\
\text { destes indivíduos em relação } \\
\text { à QVT. }\end{array}$ & $\begin{array}{l}\text { Walton } \\
\text { (1973) }\end{array}$ & $\begin{array}{l}\text { Os principais resultados } \\
\text { identificam que os trabalhadores } \\
\text { possuem um senso crítico } \\
\text { comum à respeito dos diversos } \\
\text { fatores pesquisados, externando } \\
\text { uma opinião que deixa claro leve } \\
\text { insatisfação em relação aos } \\
\text { fatores consultados nas quatro } \\
\text { empresas pesquisadas. }\end{array}$ \\
\hline 2001 & GRABARSCHI, & Qualidade de Vida no & Mestrado & QVT & Satisfação quanto à & Estudar a QVT e sua relação & Walton & Pôde-se confirmar a existência \\
\hline
\end{tabular}




\begin{tabular}{|c|c|c|c|c|c|c|c|c|}
\hline Ano & Autor & Título & Natureza & Tema & Foco & Objetivo & $\begin{array}{l}\text { Modelo } \\
\text { Teórico }\end{array}$ & Resultados \\
\hline & I.V.S.S. & 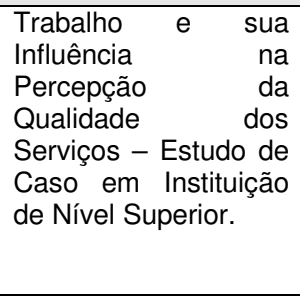 & PPGEP/UFSC & $\begin{array}{l}\text { Qualidade } \\
\text { dos Serviços }\end{array}$ & $\begin{array}{l}\text { qualidade de vida no } \\
\text { trabalho dos } \\
\text { funcionários e a } \\
\text { percepção dos } \\
\text { acadêmicos quanto à } \\
\text { qualidade dos } \\
\text { serviços prestados. }\end{array}$ & $\begin{array}{l}\text { com a percepção da qualidade } \\
\text { dos serviços prestados numa } \\
\text { Instituição de Ensino Superior. }\end{array}$ & $(1973)$ & $\begin{array}{l}\text { da influência entre a satisfação } \\
\text { no trabalho e a percepção da } \\
\text { qualidade dos serviços } \\
\text { prestados. É possível investigar } \\
\text { a influência da satisfação no } \\
\text { trabalho sobre a percepção que } \\
\text { os usuários têm à respeito da } \\
\text { qualidade dos serviços } \\
\text { prestados. }\end{array}$ \\
\hline 2001 & $\begin{array}{l}\text { TOLFO, S.R. ; } \\
\text { PICCININI, V.C. }\end{array}$ & $\begin{array}{lr}\text { As } & \text { Melhores } \\
\text { Empresas para } & \text { para } \\
\text { Trabalhar no Brasil e } \\
\text { a Qualidade de Vida } \\
\text { no Trabalho: } \\
\text { Disjunções entre a } \\
\text { Teoria e a Prática }\end{array}$ & Artigo RAC & QVT & $\begin{array}{l}\text { Pessoal de recursos } \\
\text { humanos e } \\
\text { funcionários } \\
\text { escolhidos } \\
\text { aleatoriamente } \\
\text { pertencentes a } \\
\text { diversas empresas. }\end{array}$ & $\begin{array}{l}\text { Discutir os principais } \\
\text { resultados das pesquisas } \\
\text { elaboradas pelo Great Place } \\
\text { to Work (Robert Levering), e } \\
\text { publicadas na revista Exame } \\
\text { (1997, 1999, 2000), as quais } \\
\text { mostram o panorama atual } \\
\text { das empresas brasileiras que } \\
\text { oferecem as condições de } \\
\text { trabalho mais atraentes para } \\
\text { os seus empregados. }\end{array}$ & $\begin{array}{l}\text { Walton } \\
\text { (1973) }\end{array}$ & $\begin{array}{l}\text { No conjunto, observou-se uma } \\
\text { redução do número de } \\
\text { empresas e de itens em relação } \\
\text { aos quais elas receberam a } \\
\text { avaliação máxima por parte dos } \\
\text { empregados. }\end{array}$ \\
\hline 2001 & $\begin{array}{l}\text { OLIVEIRA, R. } \\
\text { C. M.; } \\
\text { MORAES, L. F. } \\
\text { R. }\end{array}$ & $\begin{array}{l}\text { Qualidade de Vida no } \\
\text { Trabalho: uma } \\
\text { Análise no Contexto } \\
\text { de Trabalho dos } \\
\text { Detetives da Polícia } \\
\text { Civil Metropolitana de } \\
\text { Belo Horizonte }\end{array}$ & Artigo ENANPAD & QVT & $\begin{array}{l}\text { Detetives da Polícia } \\
\text { Metropolitana de BH }\end{array}$ & $\begin{array}{l}\text { Mensurar o nível de Qualidade } \\
\text { de Vida no Trabalho (QVT) na } \\
\text { carreira dos detetives lotados } \\
\text { na Superintendência de } \\
\text { Polícia Metropolitana de Belo } \\
\text { Horizonte (METROPOL). }\end{array}$ & $\begin{array}{l}\text { Walton } \\
\text { (1973) }\end{array}$ & $\begin{array}{l}\text { Percebemos que os detetives } \\
\text { estão insatisfeitos em relação à } \\
\text { grande parte dos critérios } \\
\text { pesquisados, o que deveria } \\
\text { levar a organização a um } \\
\text { repensar sobre sua estrutura de } \\
\text { trabalho e, principalmente, sobre } \\
\text { a questão da valorização de seu } \\
\text { profissional, tanto financeira } \\
\text { quanto não-financeira. }\end{array}$ \\
\hline 2000 & $\begin{array}{l}\text { MONACO, F.F; } \\
\text { GUIMARÂES, } \\
\text { V.N. }\end{array}$ & $\begin{array}{l}\text { Gestão da Qualidade } \\
\text { Total e Qualidade de } \\
\text { Vida no Trabalho: o } \\
\text { Caso da Gerência de } \\
\text { Administração dos } \\
\text { Correios }\end{array}$ & Artigo RAC & $\begin{array}{l}\text { Qualidade } \\
\text { Total e QVT }\end{array}$ & $\begin{array}{l}\text { Gerentes, chefias, } \\
\text { técnicos e nível } \\
\text { operacional dos } \\
\text { Correios. }\end{array}$ & $\begin{array}{l}\text { Levar ao conhecimento do } \\
\text { público os resultados de um } \\
\text { estudo cujo tema vem sendo } \\
\text { muito discutido nos meios } \\
\text { acadêmicos, assim como no } \\
\text { âmbito empresarial. }\end{array}$ & $\begin{array}{l}\text { Walton } \\
\text { (1973) }\end{array}$ & $\begin{array}{l}\text { Em relação aos critérios } \\
\text { investigados, encontrou-se } \\
\text { maior } \\
\text { satisfação entre os indicadores } \\
\text { de ambiente físico de trabalho, } \\
\text { significado e identidade de } \\
\text { tarefa, crescimento profissional, } \\
\text { relacionamento interpessoal, } \\
\text { senso comunitário, respeito às } \\
\text { leis e direitos trabalhistas, } \\
\text { normas e rotinas, liberdade de } \\
\text { expressão, imagem da empresa } \\
\text { e responsabilidade da empresa } \\
\text { por produtos e serviços. }\end{array}$ \\
\hline
\end{tabular}


Goulart \& Sampaio (1999) sugerem que o motivo pelo qual a teoria de Walton é largamente utilizada por pesquisadores brasileiros (Quadro 3.1), deve-se ao fato de abordar desde as necessidades básicas do ser humano até as condições da organização, passando pelas necessidades secundárias dos indivíduos, dando ênfase à auto-realização.

\subsection{O Modelo de Hackman \& Oldham (1975)}

Hackman \& Oldham (1975) sustentaram que a positividade pessoal e o resultado do trabalho (motivação interna, satisfação no trabalho e qualidade no desempenho elevadas, absenteísmo e rotatividade baixos) são obtidos quando os três estados psicológicos (Significação Percebida, Responsabilidade Percebida, Conhecimento dos Resultados do Trabalho) estão presentes num determinado trabalho.

Estes estados são criados, segundo os referidos autores, por 05 (cinco) dimensões básicas do trabalho:

Variedade de Habilidade: o grau em que um trabalho requer uma variedade de habilidades para realizar a atividade, envolvendo o uso de diferentes habilidades e talentos do funcionário;

Identidade da Tarefa: o grau em que um trabalho requer a identificação da atividade como um todo, ou seja, realizar um trabalho do início ao fim, tendo um resultado visível;

Significado da Tarefa: o grau em que o trabalho tem impacto na vida de outras pessoas, seja na organização ou fora dela; 
Autonomia: o grau em que o trabalho proporciona liberdade, independência e autonomia para o funcionário desempenhar as atividades e determinar os procedimentos a serem utilizados para realizar o trabalho;

Feedback: o grau em que o funcionário recebe informações sobre sua eficiência ou performance pela realização das atividades.

Tal modelo foca muito a questão do cargo, e uma vez identificadas essas variáveis, é possível se obter um resultado que reflete o potencial motivacional de uma tarefa em função de suas características (Goulart \& Sampaio, 1999).

Os estudos desenvolvidos no Brasil (Quadro 3.2) mostram que o modelo de Hackman e Oldham é utilizado com maior freqüência para discutir qualidade de vida no trabalho (Oliveira, 2002; Paiva et al., 2002; Honorio et al., 2001; Moraes et al., 2001; Taylor, 2000; Honório et al., 2000; Sant'Anna et al., 2000; Marassia, 2000). 
Quadro 3.2 - Publicações realizadas dentro do modelo de Hackman \& Oldham (1975) entre os anos 2000 e 2005

\begin{tabular}{|c|c|c|c|c|c|c|c|c|}
\hline Ano & Autor & Título & Natureza & Tema & Foco & Objetivo & $\begin{array}{l}\text { Modelo } \\
\text { Teórico }\end{array}$ & Resultados \\
\hline 2005 & $\begin{array}{l}\text { BORGES, R. S. } \\
\text { G. }\end{array}$ & $\begin{array}{lr}\text { Investigando } & \text { as } \\
\text { relações } & \text { entre } \\
\text { políticas de recursos } \\
\text { humanos e os } \\
\text { construtos } \\
\text { comprometimento e } \\
\text { qualidade de vida no } \\
\text { trabalho }\end{array}$ & $\begin{array}{l}\text { Mestrado } \\
\text { CEPEAD/UFMG }\end{array}$ & $\begin{array}{l}\text { Comprometimento } \\
\text { e Qualidade de } \\
\text { Vida no Trabalho }\end{array}$ & $\begin{array}{l}\text { Trabalhadores de } \\
\text { diversos níveis } \\
\text { de uma indústria } \\
\text { de mineração. }\end{array}$ & $\begin{array}{l}\text { Verificar as relações entre } \\
\text { as políticas de recursos } \\
\text { humanos }\end{array}$ & $\begin{array}{l}\text { Hackman } \\
\text { \& Oldham } \\
\text { (1975) }\end{array}$ & $\begin{array}{l}\text { Os resultados sugerem que há } \\
\text { uma grande influência do } \\
\text { construto Políticas de RH nas } \\
\text { satisfações contextuais. }\end{array}$ \\
\hline 2003 & SÍCOLI, C. R. & $\begin{array}{l}\text { Qualidade de Vida e } \\
\text { fontes de pressão no } \\
\text { trabalho do consultor } \\
\text { organizacional em BH }\end{array}$ & $\begin{array}{l}\text { Mestrado } \\
\text { CEPEAD/UFMG }\end{array}$ & $\begin{array}{l}\text { Qualidade de Vida } \\
\text { e Consultoria } \\
\text { Organizacional }\end{array}$ & $\begin{array}{ll}\text { Consultores } & \\
\text { externos } & \text { de } \\
\text { empresas } & \end{array}$ & $\begin{array}{l}\text { Retratar a realidade da } \\
\text { qualidade de vida no } \\
\text { trabalho desta } \\
\text { profissionais que atuam } \\
\text { como consultores de } \\
\text { empresas e conhecer as } \\
\text { fontes de pressão no } \\
\text { trabalho presentes em seu } \\
\text { dia-a-dia. }\end{array}$ & $\begin{array}{l}\text { Hackman } \\
\text { \& Oldham } \\
\text { (1975) }\end{array}$ & $\begin{array}{l}\text { A necessidade constante de } \\
\text { estar em busca de trabalho, a } \\
\text { ausência de estabilidade ou } \\
\text { seguranças financeiras, o fato } \\
\text { de não conseguir se desligar do } \\
\text { trabalho, mesmo estando em } \\
\text { casa, são fontes de pressão que } \\
\text { podem fazer com que } \\
\text { consultores coloquem a família } \\
\text { em segundo plano e trazer } \\
\text { prejuízos às relações familiares, } \\
\text { comprometendo a qualidade de } \\
\text { vida no trabalho dos consultores } \\
\text { organizacionais. }\end{array}$ \\
\hline 2002 & OLIVEIRA, N. & $\begin{array}{l}\text { Mudanças } \\
\text { Organizacionais e } \\
\text { Qualidade de Vida no } \\
\text { Trabalho: um Estudo } \\
\text { Comparativo-temporal } \\
\text { em Unidades do } \\
\text { Banco do Brasil S.A }\end{array}$ & Artigo ENANPAD & $\begin{array}{l}\text { Mudança } \\
\text { Organizacional e } \\
\text { Qualidade de Vida } \\
\text { no Trabalho }\end{array}$ & $\begin{array}{l}\text { Funcionários de } \\
\text { instituição } \\
\text { bancária }\end{array}$ & $\begin{array}{l}\text { Procurou revisitar as } \\
\text { unidades objeto de } \\
\text { pesquisa em } 1990 \text { e fazer } \\
\text { uma comparação para } \\
\text { verificar as conseqüências } \\
\text { das mudanças na } \\
\text { empresa para a satisfação } \\
\text { de seus funcionários. }\end{array}$ & $\begin{array}{l}\text { Hackman } \\
\text { \& Oldham } \\
\text { (1975) }\end{array}$ & $\begin{array}{l}\text { Os principais resultados } \\
\text { apontam para melhorias no que } \\
\text { se refere aos fatores intrínsecos } \\
\text { apenas para a unidade em que, } \\
\text { anteriormente, existia um } \\
\text { trabalho rotineiro e sem contato } \\
\text { com clientes (atividade-meio). } \\
\text { Quanto aos fatores extrínsecos, } \\
\text { verificou-se, de forma geral, } \\
\text { diminuição nos índices. }\end{array}$ \\
\hline 2002 & $\begin{array}{l}\text { PAIVA, K. C. } \\
\text { M.; } \\
\text { DEUSDEDIT } \\
\text { JR, M.; SILVA, } \\
\text { M. A. } \quad \text { L.; } \\
\text { VALENÇA, M. } \\
\text { C. A. }\end{array}$ & $\begin{array}{l}\text { Situação de Trabalho, } \\
\text { Qualidade de Vida e } \\
\text { Estresse no Ambiente } \\
\text { Acadêmico: } \\
\text { comparando } \\
\text { professores de } \\
\text { instituições pública, } \\
\text { privada e confessional }\end{array}$ & Artigo ENANPAD & $\begin{array}{l}\text { QVT e Estresse } \\
\text { Ocupacional }\end{array}$ & $\begin{array}{l}\text { Professor } \\
\text { universitário }\end{array}$ & $\begin{array}{l}\text { Caracterizar o professor } \\
\text { universitário no que diz } \\
\text { respeito às variáveis de } \\
\text { situação profissional, de } \\
\text { QVT e de estresse } \\
\text { ocupacional, tendo em } \\
\text { vista os multivariados } \\
\text { impactos que a categoria } \\
\text { vem sofrendo em função } \\
\text { do aumento contínuo da }\end{array}$ & $\begin{array}{l}\text { Hackman } \\
\& \text { Oldham } \\
\text { (1975) }\end{array}$ & $\begin{array}{l}\text { Os dados demonstram níveis } \\
\text { considerados satisfatórios de } \\
\text { QVT (elevados) e de estresse } \\
\text { (baixos) nos grupos, } \\
\text { independentemente de tipo de } \\
\text { dedicação às atividades } \\
\text { acadêmicas. }\end{array}$ \\
\hline
\end{tabular}




\begin{tabular}{|c|c|c|c|c|c|c|c|c|}
\hline Ano & Autor & Título & Natureza & Tema & Foco & Objetivo & $\begin{array}{l}\text { Modelo } \\
\text { Teórico }\end{array}$ & Resultados \\
\hline & & & & & & $\begin{array}{ll}\text { complexidade } & \text { do } \\
\text { ambiente. } & \end{array}$ & & \\
\hline 2002 & $\begin{array}{l}\text { KILIMNIK, Z. M, } \\
\text { CASTILHO, I. V. }\end{array}$ & $\begin{array}{l}\text { Trajetórias } \\
\text { transições de carreira: } \\
\text { um estudo longitudinal } \\
\text { sobre a qualidade de } \\
\text { vida de profissionais } \\
\text { assalariados de } \\
\text { recursos humanos que } \\
\text { experimentaram a } \\
\text { passagem a trabalho } \\
\text { para o } \\
\text { autônomo. }\end{array}$ & Artigo ENANPAD & $\begin{array}{l}\text { Qualidade de vida } \\
\text { no Trabalho e } \\
\text { Satisfação }\end{array}$ & $\begin{array}{ll}\text { Profissionais } & \\
\text { integrantes } & \text { de } \\
\text { um grupo } & \text { de } \\
\text { intercâmbio } & \text { em } \\
\text { Recursos } & \\
\text { Humanos } & \end{array}$ & $\begin{array}{l}\text { Investigar a transição e } \\
\text { trajetória de carreira de } \\
\text { profissionais de Recursos } \\
\text { Humanos, com a } \\
\text { expectativa de se poder } \\
\text { contribuir para o estudo } \\
\text { das diversas outras } \\
\text { profissões. }\end{array}$ & $\begin{array}{l}\text { Hackman } \\
\text { \& Oldham } \\
\text { (1975) }\end{array}$ & $\begin{array}{l}\text { Os achados mostraram que o } \\
\text { trabalho autônomo pode } \\
\text { proporcionar um conteúdo } \\
\text { laboral mais significativo, devido } \\
\text { à diversificação de experiências } \\
\text { profissionais, mas, por outro } \\
\text { lado, pode envolver dificuldades, } \\
\text { principalmente aquelas } \\
\text { associadas à obtenção de } \\
\text { ganhos regulares e em nível } \\
\text { adequado. }\end{array}$ \\
\hline 2001 & $\begin{array}{l}\text { HONORIO, L. } \\
\text { C.; MARQUES, } \\
\text { A. L.; MELO, M. } \\
\text { S. }\end{array}$ & $\begin{array}{l}\text { Qualidade de Vida no } \\
\text { Trabalho em uma } \\
\text { Empresa do Comércio } \\
\text { Varejista }\end{array}$ & Artigo ENANPAD & $\begin{array}{l}\text { Qualidade de Vida } \\
\text { no Trabalho e } \\
\text { Pequena Empresa }\end{array}$ & 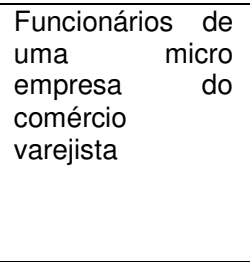 & $\begin{array}{l}\text { Diagnosticar a Qualidade } \\
\text { de Vida no Trabalho em } \\
\text { uma micro empresa do } \\
\text { comércio varejista. }\end{array}$ & $\begin{array}{l}\text { Hackman } \\
\text { \& Oldham } \\
\text { (1975) }\end{array}$ & $\begin{array}{l}\text { Foi possível constatar que a } \\
\text { qualidade de vida no trabalho } \\
\text { mostrou-se satisfatória para } \\
\text { todas as variáveis medidas. } \\
\text { Porém, algumas situações } \\
\text { observadas merecem um pouco } \\
\text { mais de atenção da empresa } \\
\text { quanto ao seu equacionamento. }\end{array}$ \\
\hline 2001 & $\begin{array}{l}\text { MORAES, L. F. } \\
\text { R.; PEREIRA, L. } \\
\text { Z.; LOPES, H. } \\
\text { E. G.; ROCHA, } \\
\text { D. B., } \\
\text { FERREIRA, S. } \\
\text { A. A.; PORTES, } \\
\text { P. C.P. }\end{array}$ & $\begin{array}{l}\text { Estresse e Qualidade } \\
\text { de Vida no Trabalho } \\
\text { na Polícia Militar do } \\
\text { Estado de Minas } \\
\text { Gerais }\end{array}$ & Artigo ENANPAD & $\begin{array}{l}\text { QVT e Estresse } \\
\text { Ocupacional }\end{array}$ & $\begin{array}{l}\text { Membros } \\
\text { Polícia Militar }\end{array}$ & $\begin{array}{l}\text { Estudar a QVT e Estresse } \\
\text { Ocupacional dos membros } \\
\text { da Polícia Militar. }\end{array}$ & $\begin{array}{l}\text { Hackman } \\
\text { \& Oldham } \\
\text { (1975) }\end{array}$ & $\begin{array}{l}\text { Constatou-se a existência de } \\
\text { importantes níveis de estresse } \\
\text { entre os membros da } \\
\text { Corporação, decorrentes de } \\
\text { elevada insatisfação em relação } \\
\text { à Instituição. }\end{array}$ \\
\hline 2000 & $\begin{array}{l}\text { MARASSIA D. } \\
\text { C. C. }\end{array}$ & $\begin{array}{l}\text { Liderança e Qualidade } \\
\text { de Vida Dentro do } \\
\text { Trabalho }\end{array}$ & Doutorado/FFCLRP & $\begin{array}{l}\text { Liderança e } \\
\text { qualidade de vida }\end{array}$ & $\begin{array}{l}\text { Profissionais do } \\
\text { Corpo de } \\
\text { Bombeiros e } \\
\text { Agro-indústrias } \\
\text { de Ribeirão Preto }\end{array}$ & $\begin{array}{l}\text { Investigar a relação entre } \\
\text { os estilos de liderança e o } \\
\text { contexto organizacional, } \\
\text { considerando a percepção } \\
\text { da qualidade de vida no } \\
\text { trabalho, que engloba o } \\
\text { clima organizacional, a } \\
\text { cultura, motivação, } \\
\text { comprometimento, entre } \\
\text { outros fatores que } \\
\text { interferem no estilo de } \\
\text { liderança. }\end{array}$ & $\begin{array}{l}\text { Hackman } \\
\text { \& Oldham } \\
\text { (1975) }\end{array}$ & $\begin{array}{l}\text { Foi observado que não houve } \\
\text { diferença significativa para } \\
\text { liderança e QVT. }\end{array}$ \\
\hline 2000 & $\begin{array}{l}\text { HONÓRIO, L. } \\
\text { C.;BRAGA, J. } \\
\text { O.; MARQUES, } \\
\text { A. L. }\end{array}$ & $\begin{array}{l}\text { Qualidade de Vida e } \\
\text { Estresse no Trabalho: } \\
\text { o Caso de uma } \\
\text { Instituição Religiosa }\end{array}$ & Artigo ENANPAD & $\begin{array}{l}\text { QVT e Estresse } \\
\text { Ocupacional }\end{array}$ & $\begin{array}{l}\text { Profissionais } \\
\text { religiosos }\end{array}$ & $\begin{array}{l}\text { Investigar o grau em que } \\
\text { características como alto } \\
\text { grau de idealização nas } \\
\text { tarefas que realiza } \\
\text { favorece o aparecimento }\end{array}$ & $\begin{array}{l}\text { Hackman } \\
\text { \& Oldham } \\
\text { (1975) }\end{array}$ & $\begin{array}{l}\text { Constatou-se que a maioria das } \\
\text { variáveis de QVT medidas foram } \\
\text { avaliadas de maneira satisfatória } \\
\text { pelos participantes desta } \\
\text { pesquisa. Situacão diferente foi }\end{array}$ \\
\hline
\end{tabular}




\begin{tabular}{|c|c|c|c|c|c|c|c|c|}
\hline Ano & Autor & Título & Natureza & Tema & Foco & Objetivo & Modelo & Resultados \\
\hline & & & & & & $\begin{array}{lrr}\text { de doenças } & \text { físicas } & \text { e } \\
\text { emocionais } & \text { que possam } \\
\text { prejudicar o } & \text { desempenho } \\
\text { ocupacional } & \text { de } \\
\text { profissionais } & \text { de uma } \\
\text { tradicional } & \text { instituição } \\
\text { religiosa. } & & \end{array}$ & & $\begin{array}{l}\text { encontrada com relação às } \\
\text { variáveis } \\
\text { Ocupacional, que apontaram os } \\
\text { pesquisados com significativa } \\
\text { propensão ao estresse. }\end{array}$ \\
\hline 2000 & $\begin{array}{l}\text { SANT'ANNA, } \\
\text { S., COSTA, R. } \\
\text { C. M. M.; } \\
\text { MORAES, L.. F. } \\
\text { R. }\end{array}$ & $\begin{array}{l}\text { Qualidade de Vida no } \\
\text { Trabalho: uma Análise } \\
\text { em Unidades de } \\
\text { Ensino Básico }\end{array}$ & Artigo ENANPAD & QVT e Estresse & $\begin{array}{l}\text { Professores de } \\
\text { quatro unidades } \\
\text { de ensino de } \\
\text { uma instituição } \\
\text { privada de } \\
\text { educação do } \\
\text { Estado de Minas } \\
\text { Gerais }\end{array}$ & $\begin{array}{l}\text { Investigar os elementos } \\
\text { que, na percepção dos } \\
\text { mesmos, constituem } \\
\text { fatores basilares de QVT. }\end{array}$ & $\begin{array}{l}\text { Hackman } \\
\text { \& Oldham } \\
\text { (1975) }\end{array}$ & $\begin{array}{l}\text { Os resultados indicam que os } \\
\text { respondentes apresentaram } \\
\text { uma qualidade de vida no } \\
\text { trabalho satisfatória, assim como } \\
\text { níveis de tensão dentro dos } \\
\text { padrões de normalidade. } \\
\text { Ressalta-se a constatação da } \\
\text { relevância do ferramental da } \\
\text { qualidade de vida no trabalho } \\
\text { como instrumento de apoio à } \\
\text { gestão de recursos humanos, na } \\
\text { medida em que potencializa o } \\
\text { estabelecimento de canais de } \\
\text { diálogo entre empresa e } \\
\text { empregados, permitindo, por } \\
\text { conseguinte, ações } \\
\text { organizacionais mais efetivas. }\end{array}$ \\
\hline 2000 & TAYLOR, C. R. & $\begin{array}{l}\text { Qualidade de Vida no } \\
\text { Trabalho: Resultados } \\
\text { a partir da Implantação } \\
\text { de um Modelo de } \\
\text { Qualidade Total (TQM) }\end{array}$ & Artigo ENANPAD & $\begin{array}{l}\text { QVT e Qualidade } \\
\text { Total }\end{array}$ & $\begin{array}{l}\text { Funcionários de } \\
\text { nível operacional } \\
\text { de indústria de } \\
\text { plásticos. }\end{array}$ & $\begin{array}{l}\text { Estudar o impacto de um } \\
\text { programa de TQM na QVT } \\
\text { em uma organização do } \\
\text { segmento de plásticos. }\end{array}$ & $\begin{array}{l}\text { Hackman } \\
\text { \& Oldham } \\
\text { (1975) }\end{array}$ & $\begin{array}{l}\text { Os resultados apontaram que o } \\
\text { nível de implementação de TQM } \\
\text { foi entendido como médio e a } \\
\text { QVT sofreu um impacto positivo } \\
\text { a partir da implementação do } \\
\text { TQM, porém não na extensão } \\
\text { esperada. }\end{array}$ \\
\hline
\end{tabular}




\subsection{O Modelo de Westley (1979)}

Outro modelo que pode ser destacado, relacionando a organização do trabalho à QVT, é o modelo de Westley (Westley apud Goulart \& Sampaio, 1999), que aborda quatro dimensões: a política (segurança/insegurança), a econômica (eqüidade salarial e de tratamento/injustiça), a psicológica (auto-realização/alienação) e a sociológica (participação). Segundo tais autores, problemas como insegurança e injustiça estão presentes há séculos, e este fato se explica pela concentração de poder e lucros na mão de alguns, e também pela exploração da força de trabalho, que foram amenizadas com o movimento socialista, mas que, por outro lado, contribuíram para o surgimento da alienação. A alienação refere-se à perda do sentido do trabalho e do próprio ser, não permitindo que o homem se realize através dele.

\subsection{O Modelo de Werther \& Davis (1983)}

Trabalha com as questões de cargo nos níveis organizacional (propósitos, objetivos, atividades da organização e sua departamentalização e eficiência), ambiental (fatores macroestruturais relativos à cultura, determinantes históricos, econômicos, sociais, tecnológicos e governamentais) e comportamental (necessidade dos trabalhadores: autonomia, variedade, identidade da tarefa e retroinformação) (Goulart \& Sampaio, 1999). O foco do modelo voltase para a valorização dos cargos, mediante análise de elementos organizacionais, ambientais e comportamentais, salientando que um bom trabalho é aquele que apresenta um cargo interessante, desafiador e compensador, e este deve ser estabelecido com a participação dos trabalhadores afetados, pois acredita que os cargos são o elo entre as pessoas e a organização (Werther \& Davis, 1983). O cargo deve incluir as competências de cada trabalhador e é o referencial para a construção da carreira individual: à medida que as competências se ampliam ou se alteram, ocorrem as promoções de um a outro cargo, confirmando o sucesso do sujeito. 
Quadro 3.3 - Publicação realizada dentro do modelo de Werther \& Davis (1983)

\begin{tabular}{|c|c|c|c|c|c|c|c|c|}
\hline Ano & Autor & Título & Natureza & Tema & Foco & Objetivo & $\begin{array}{l}\text { Modelo } \\
\text { Teórico }\end{array}$ & Resultados \\
\hline 2002 & $\begin{array}{l}\text { MEDEIROS, } \\
\text { E. G. }\end{array}$ & $\begin{array}{l}\text { Análise da } \\
\text { Qualidade de } \\
\text { Vida no } \\
\text { Trabalho: um } \\
\text { Estudo de Caso } \\
\text { na Área da } \\
\text { Construção Civil }\end{array}$ & $\begin{array}{l}\text { Mestrado - } \\
\text { PPGA/UFRGS }\end{array}$ & $\begin{array}{l}\text { Qualidade } \\
\text { de Vida no } \\
\text { Trabalho }\end{array}$ & $\begin{array}{l}\text { Funcionários de } \\
\text { uma empresa no } \\
\text { RS atuando na } \\
\text { construção civil } \\
\text { (Ediba) }\end{array}$ & $\begin{array}{l}\text { Analisar a satisfação dos } \\
\text { trabalhadores quanto aos principais } \\
\text { fatores intervenientes em sua } \\
\text { Qualidade de Vida no Trabalho } \\
\text { (QVT), identificando aspectos que, } \\
\text { se melhores gerenciados, } \\
\text { poderiam propiciar melhorias em } \\
\text { sua qualidade de vida, com } \\
\text { reflexos no desempenho } \\
\text { organizacional. }\end{array}$ & $\begin{array}{l}\text { Werther } \\
\text { e Davis } \\
\text { (1983) }\end{array}$ & $\begin{array}{l}\text { Os resultados da pesquisa revelaram que os } \\
\text { trabalhadores da Ediba sentem-se satisfeitos, } \\
\text { embora não totalmente, com sua qualidade de } \\
\text { vida. Todos os elementos de QVT } \\
\text { investigados apresentaram resultados } \\
\text { significativos, sendo que o maior grau de } \\
\text { satisfação dos trabalhadores foi demonstrado } \\
\text { em relação aos Elementos Ambientais, } \\
\text { seguindo-se dos Comportamentais e, por fim, } \\
\text { dos Organizacionais. }\end{array}$ \\
\hline
\end{tabular}




\subsection{O Modelo de Belanger (1983)}

O modelo de Belanger (1983) apud Benavides (2000), quando analisa a QVT, aponta algumas variáveis a serem consideradas:

o trabalho em si: criatividade, variabilidade, autonomia, envolvimento e feedback;

crescimento pessoal e profissional: treinamento, oportunidades de crescimento, relacionamento no trabalho e papéis organizacionais;

tarefas com significado: tarefas completas, responsabilidade aumentada, recompensas financeiras e não-financeiras e enriquecimento; e,

funções e estruturas organizacionais abertas: clima de criatividade e transferência de objetivos.

\subsection{O Modelo de Huse \& Cummings (1985)}

Relaciona a QVT e a produtividade, estando explicitada em quatro programas: a participação do trabalhador, o projeto de cargos, a inovação no sistema de recompensas e a melhoria no ambiente de trabalho. A conscientização dos trabalhadores e o aumento das responsabilidades sociais da empresa contribuíram para a busca de melhores formas de se realizar o trabalho (Goulart \& Sampaio, 1999). Tal modelo destaca o tripé pessoa, trabalho e organização, nos aspectos do bem-estar do trabalhador e a eficácia organizacional, e participação nas decisões e problemas do trabalho. 
Quadro 3.4 - Resumo dos Modelos Teóricos de Qualidade de Vida no Trabalho

\begin{tabular}{|c|c|}
\hline Modelo Teórico & Dimensões Consideradas \\
\hline Walton (1973) & $\begin{array}{l}>\text { Compensação justa e adequada } \\
>\quad \text { Condições de trabalho seguras e saudáveis } \\
>\quad \text { Oportunidades imediatas para desenvolver e usar as capacidades } \\
>\text { Opumanas } \\
>\quad \text { Integração social na organização } \\
>\text { Constitucionalismo na organização } \\
>\quad \text { Trabalho e espaço total na vida } \\
>\text { Relevância social do trabalho }\end{array}$ \\
\hline Hackman \& Oldham (1975) & $\begin{array}{l}>\text { Variedade de Habilidade } \\
>\text { Identidade da Tarefa } \\
>\text { Significado da Tarefa } \\
>\text { Autonomia } \\
>\text { Feedback }\end{array}$ \\
\hline Westley (1979) & $\begin{array}{l}>\text { Política } \\
>\text { Econômica } \\
>\text { Psicológica } \\
>\text { Sociológica }\end{array}$ \\
\hline Werther \& Davis (1983) & $\begin{array}{l}>\text { Organizacional } \\
>\quad \text { Ambiental } \\
>\text { Comportamental }\end{array}$ \\
\hline Belanger (1983) & $\begin{array}{l}>\text { Trabalho em si } \\
>\text { Crescimento pessoal e profissional } \\
>\text { Tarefas com significado } \\
>\text { Funções e estruturas organizacionais abertas }\end{array}$ \\
\hline Huse \& Cummings (1985) & $\begin{array}{l}>\text { Participação do trabalhador } \\
>\text { Projeto de cargos } \\
>\quad \text { Inovação no sistema de recompensas } \\
>\quad \text { Melhoria no ambiente de trabalho }\end{array}$ \\
\hline
\end{tabular}

\subsection{O Modelo conceitual de competências para a Qualidade de Vida no Trabalho}

O objeto deste estudo é o modelo de competências para a QVT, criado a partir da definição dos fatores críticos da gestão QVT. Percebe-se a evolução dos modelos, devido às demandas do ambiente externo e as novas formas de organização do trabalho. Ainda que bem atuais e muito utilizados, é pertinente colocar algumas ressalvas quanto aos modelos expostos anteriormente. 
Vários deles concentram-se na valorização dos cargos (Hackman \& Oldham, 1975; Werther \& Davis, 1983; Huse \& Cummings, 1985), o que os torna questionáveis, dado o surgimento do modelo competitivo de gestão por competências (Fischer, A., 2002): tais modelos não permitem que se saia da gestão tradicional. Embora muito válidos, dada a sua adoção e resultados, é importante considerar as questões de QVT dentro de uma perspectiva de gestão avançada, entendida como uma nova competência a se desenvolver no profissional. Nesta lógica, Limongi-França (2003), entende que, através dos fatores críticos, ou seja, aquelas competências essenciais que a organização precisa apresentar, os funcionários sentiriam que a organização seria capaz de proporcionar um ambiente voltado para o bemestar do empregado. Os fatores críticos propostos são: Conceito de QVT, Produtividade, Legitimidade, Perfil do Gestor, Práticas e Valores, e Nova Competência.

\subsubsection{Gestão da Qualidade de Vida no Trabalho}

Limongi-França (1996, p.8) conceitua Gestão da Qualidade de Vida no Trabalho (GQVT) como “o conjunto das ações de uma empresa que envolve a implantação de melhorias e inovações gerenciais, tecnológicas e estruturais do ambiente de trabalho". Ademais, a autora menciona inúmeros outros conceitos desenvolvidos por diferentes estudiosos ao longo dos anos. Além daqueles que desenvolveram modelos teóricos, vale ressaltar o conceito de Drucker (1991), que coloca ênfase na responsabilidade social da empresa, ou seja, destaca a necessidade dos gestores dirigirem suas instituições olhando para a sociedade, pois é incompatível possuir uma empresa sadia e uma sociedade doente, e além disso, o autor destaca que de certa forma, os problemas sociais são disfunções da sociedade e não necessariamente, impactos da organização e de suas atividades. 
Lippitt \& Camacho (apud Limongi-França, 1996) vêem QVT como trabalho, crescimento pessoal e sobrevivência com dignidade, segurança, participação e perspectiva de futuro. Dantas (apud Limongi-França, 1996) coloca o foco na promoção da saúde, enquanto Fernandes (1992) destaca a humanização do cargo.

Em levantamentos realizados por Nunes (1999) e Honório et al. (2001), alguns setores de atividade foram alvos de pesquisa em QVT: instituições bancárias, imobiliárias, construção civil, hospitais, universidades, tecnologia de sistemas de iluminação, indústria de confecções, motores elétricos, autopeças, empresas de informática e telecomunicações. Outros estudiosos desenvolveram pesquisas no tema em instituições religiosas (Honório et al., 2000), comércio de artigos culinários (Honório et al., 2001), corpo de bombeiros e agroindústria (Marassia, 2000), setor público (Moraes et al., 2001), instituições educacionais (SantAnna, 2000), hospitais (Cunha, 2004). Benavides (2000) traçou o link entre a QVT e a gestão estratégica de recursos humanos através de um estudo de caso da empresa Van Den Bergh intitulado "Projeto Viver Bem".

Nunes (1999) e Honório et al. (2001) focaram seus estudos em atividades ocupacionais, destacando os bibliotecários, psicólogos, enfermeiros, médicos, professores e bancários. Outras profissões observadas, foram os profissionais de informática (Zavattaro, 1999; Silva, 2004), servidores de universidade (Andrade, 1997) e Nunes (1999), com a exploração dos impactos da privatização na QVT através de uma avaliação sob o ponto de vista do trabalhador.

As definições de Limongi-França (2003) mostram que as experiências práticas em QVT são realizadas principalmente por assistentes sociais, seguida de psicólogos. Com isso, 
nota-se pouca ênfase dada às questões de Gestão, pois tais especialistas concentram-se muito mais nos aspectos técnicos do que no processo de gestão como um todo. 
Quadro 3.5 - Publicações realizadas sobre Qualidade de Vida no Trabalho entre os anos 2000 e 2005

\begin{tabular}{|c|c|c|c|c|c|c|c|c|}
\hline Ano & Autor & Título & Natureza & Tema & Foco & Objetivo & $\begin{array}{l}\text { Modelo } \\
\text { Teórico }\end{array}$ & Resultados \\
\hline 2004 & $\begin{array}{l}\text { CARICARI, } \\
\text { A. M. }\end{array}$ & $\begin{array}{l}\text { As condições de vida e de } \\
\text { trabalho dos trabalhadores } \\
\text { da indústria da construção } \\
\text { civil, na perspectiva da } \\
\text { promoção da saúde: } 0 \\
\text { caso de Bertioga }\end{array}$ & $\begin{array}{l}\text { Mestrado } \\
\text { Saúde } \\
\text { Pública/USP }\end{array}$ & $\begin{array}{l}\text { QVT e } \\
\text { Qualidade } \\
\text { de Vida }\end{array}$ & $\begin{array}{l}\text { Trabalhador } \\
\text { es da } \\
\text { Construção } \\
\text { Civil }\end{array}$ & $\begin{array}{l}\text { Conhecer as condições de vida e } \\
\text { trabalho dos trabalhadores da } \\
\text { construção civil de Bertioga, um dos } \\
\text { setores mais importantes da economia } \\
\text { do município. }\end{array}$ & $\begin{array}{l}\text { Perspectiva da } \\
\text { promoção da } \\
\text { saúde. }\end{array}$ & $\begin{array}{l}\text { Os resultados obtidos permitem } \\
\text { oferecer subsídios para as políticas } \\
\text { públicas locais que contribuam para a } \\
\text { inclusão do trabalhador da construção } \\
\text { civil enquanto cidadão de Bertioga, tais } \\
\text { como: criação de cooperativas de } \\
\text { serviços de manutenção e construção } \\
\text { de residências; criação de } \\
\text { cooperativas para auto construção de } \\
\text { moradias para trabalhadores da } \\
\text { construção civil; exigências de } \\
\text { contratação dos trabalhadores locais } \\
\text { nos empreendimentos no setor da } \\
\text { construção civil e programas } \\
\text { municipais de formação e capacitação } \\
\text { profissional para estes trabalhadores }\end{array}$ \\
\hline 2004 & $\begin{array}{l}\text { CARVALH } \\
\text { O, M. B. }\end{array}$ & $\begin{array}{l}\text { O trabalho de } \\
\text { enfermagem psiquiátrica e } \\
\text { os problemas de saúde } \\
\text { dos trabalhadores }\end{array}$ & $\begin{array}{l}\text { Mestrado } \\
\text { Enfermagem } \\
\text { /USP }\end{array}$ & QVT & $\begin{array}{l}\text { Trabalhador } \\
\text { es de } \\
\text { enfermagem } \\
\text { em } \\
\text { psiquiatria }\end{array}$ & $\begin{array}{l}\text { Identificar as cargas a que estão } \\
\text { expostos os trabalhadores de } \\
\text { enfermagem em um hospital psiquiátrico, } \\
\text { apreender os processos de desgaste, } \\
\text { vivenciados por eles e analisar as } \\
\text { estratégias de enfrentamento apontadas } \\
\text { pelos trabalhadores como processos } \\
\text { potencializadores de qualidade de vida } \\
\text { no trabalho. }\end{array}$ & $\begin{array}{l}\text { Laurell e } \\
\text { Noriega }\end{array}$ & $\begin{array}{l}\text { Os resultados possibilitaram apreender } \\
\text { que o objeto de trabalho, ou seja, o } \\
\text { paciente psiquiátrico é visto como } \\
\text { marginalizado e excluído socialmente, } \\
\text { o saber caracteriza-se no saber fazer. }\end{array}$ \\
\hline 2004 & LINO, M. M. & $\begin{array}{l}\text { Qualidade de vida e } \\
\text { satisfação profissional de } \\
\text { enfermeiras de unidades } \\
\text { de terapia intensiva }\end{array}$ & $\begin{array}{l}\text { Doutorado } \\
\text { Enfermagem } \\
\text { IUSP }\end{array}$ & $\begin{array}{l}\text { Qualidade } \\
\text { de Vida e } \\
\text { Satisfação } \\
\text { no Trabalho }\end{array}$ & $\begin{array}{l}\text { Enfermeiras } \\
\text { de unidades } \\
\text { de terapia } \\
\text { intensiva }\end{array}$ & $\begin{array}{l}\text { Investigar a qualidade de vida e a } \\
\text { satisfação profissional de enfermeiras de } \\
\text { Unidades de Terapia Intensiva (UTIs) e } \\
\text { examinar suas relações. }\end{array}$ & $\begin{array}{l}\text { Índice de } \\
\text { Qualidade de } \\
\text { Vida (IQV) }\end{array}$ & $\begin{array}{l}\text { Os resultados mostraram que as } \\
\text { enfermeiras obtiveram escores mais } \\
\text { elevados nos domínios família, } \\
\text { psicológico e espiritual, social e } \\
\text { econômico, saúde e funcionamento, } \\
\text { respectivamente. }\end{array}$ \\
\hline 2004 & $\begin{array}{l}\text { SCHMIDT, } \\
\text { D. R. C. }\end{array}$ & $\begin{array}{l}\text { Qualidade de vida e } \\
\text { qualidade de vida no } \\
\text { trabalho de profissionais } \\
\text { de enfermagem atuantes } \\
\text { em unidades do bloco } \\
\text { cirúrgico }\end{array}$ & $\begin{array}{l}\text { Mestrado } \\
\text { Enfermagem } \\
\text { /USP- } \\
\text { Ribeirão } \\
\text { Preto }\end{array}$ & QVT & $\begin{array}{l}\text { Enfermeiros } \\
\text { de unidades } \\
\text { do bloco } \\
\text { cirúrgico }\end{array}$ & $\begin{array}{l}\text { A hipótese principal testada nesse } \\
\text { estudo foi verificar se a qualidade de vida } \\
\text { do indivíduo está diretamente } \\
\text { correlacionada com a qualidade de vida } \\
\text { no trabalho, ou seja, quanto maior a } \\
\text { qualidade de vida no trabalho, maior a } \\
\text { qualidade de vida. }\end{array}$ & $\begin{array}{l}\text { Escala } \\
\text { Adaptada de } \\
\text { Qualidade de } \\
\text { Vida de } \\
\text { Flanagan e o } \\
\text { Índice de } \\
\text { Satisfação } \\
\text { Profissional de } \\
\text { Stamps } \\
\end{array}$ & $\begin{array}{l}\text { Não houve correlação entre as } \\
\text { variáveis, o que não comprovou a } \\
\text { nossa hipótese inicial. }\end{array}$ \\
\hline 2004 & $\begin{array}{l}\text { SILVA, R. } \\
\text { T. }\end{array}$ & $\begin{array}{l}\text { O teletrabalho e suas } \\
\text { influências na qualidade } \\
\text { de vida no trabalho }\end{array}$ & $\begin{array}{l}\text { Mestrado } \\
\text { FEA/USP }\end{array}$ & $\begin{array}{l}\text { QVT e } \\
\text { Tecnologia } \\
\text { da }\end{array}$ & $\begin{array}{l}\text { Profissionais } \\
\text { que realizam } \\
\text { suas }\end{array}$ & $\begin{array}{l}\text { Identificar como a tecnologia da } \\
\text { informação e seu uso estratégico têm } \\
\text { contribuído, ou não, com a promoção e }\end{array}$ & BPSO-96 & $\begin{array}{l}\text { Os resultados obtidos demonstram que } \\
\text { a tecnologia da informação provoca } \\
\text { mudanças nas relações do trabalhador }\end{array}$ \\
\hline
\end{tabular}




\begin{tabular}{|c|c|c|c|c|c|c|c|c|}
\hline Ano & Autor & Título & Natureza & Tema & Foco & Objetivo & $\begin{array}{l}\text { Modelo } \\
\text { Teórico }\end{array}$ & Resultados \\
\hline & & & & Informação & $\begin{array}{l}\text { atividades } \\
\text { através do } \\
\text { teletrabalho }\end{array}$ & $\begin{array}{l}\text { com a gestão da qualidade de vida no } \\
\text { trabalho. }\end{array}$ & & com o ambiente. \\
\hline 2003 & $\begin{array}{l}\text { ARELLANO } \\
\text {, E. B. }\end{array}$ & $\begin{array}{l}\text { Qualidade de vida no } \\
\text { trabalho: como a nutrição } \\
\text { está inserida nos } \\
\text { programas de QVT }\end{array}$ & $\begin{array}{l}\text { Mestrado } \\
\text { Interunidade } \\
\text { s PRONUT }\end{array}$ & $\begin{array}{l}\text { QVT e } \\
\text { Nutrição }\end{array}$ & $\begin{array}{l}\text { Funcionários } \\
\text { de } \\
\text { empresas } \\
\text { que } \\
\text { receberam o } \\
\text { prêmio } \\
\text { anual da } \\
\text { Associação } \\
\text { Brasileira de } \\
\text { Qualidade } \\
\text { de Vida }\end{array}$ & $\begin{array}{l}\text { Analisa os programas de qualidade de } \\
\text { vida no trabalho que receberam o prêmio } \\
\text { anual concedido pela ABQV - } \\
\text { Associação Brasileira de Qualidade de } \\
\text { Vida no Trabalho, no período de } 1996 \text { a } \\
2001 .\end{array}$ & $\begin{array}{l}\text { QVT com } \\
\text { impactos na } \\
\text { produtividade }\end{array}$ & $\begin{array}{l}\text { Os resultados obtidos demonstram } \\
\text { que, a maioria das empresas } \\
\text { pesquisadas está desenvolvendo } \\
\text { ações, dentro dos seus programas de } \\
\text { QVT, de orientação dos hábitos } \\
\text { alimentares de seus funcionários, } \\
\text { promovendo a saúde na tentativa de } \\
\text { diminuir a incidência de doenças } \\
\text { relacionadas a uma dieta inadequada, } \\
\text { especificamente as referentes à } \\
\text { obesidade, como as doenças } \\
\text { coronarianas. }\end{array}$ \\
\hline 2003 & $\begin{array}{l}\text { CANÇADO, } \\
\text { V. L.; } \\
\text { LOPES, D. } \\
\text { M. }\end{array}$ & $\begin{array}{l}\text { Trabalho e Saúde: um } \\
\text { Estudo sobre Ginástica } \\
\text { Laboral na Unilever }\end{array}$ & $\begin{array}{l}\text { Artigo } \\
\text { ENANPAD }\end{array}$ & $\begin{array}{l}\text { QVT e } \\
\text { Ginástica } \\
\text { Laboral }\end{array}$ & $\begin{array}{l}\text { Trabalhador } \\
\text { es e } \\
\text { gerentes } \\
\text { Unilever, } \\
\text { MG }\end{array}$ & $\begin{array}{l}\text { Discutir a percepção dos trabalhadores à } \\
\text { respeito do impacto de um programa de } \\
\text { ginástica laboral em sua saúde }\end{array}$ & $\begin{array}{l}\text { Construção de } \\
\text { um modelo a } \\
\text { partir dos } \\
\text { conceitos de } \\
\text { organização do } \\
\text { trabalho, saúde } \\
\text { do trabalhador } \\
\text { e ginástica } \\
\text { laboral. }\end{array}$ & $\begin{array}{l}\text { Os resultados demonstram que o } \\
\text { programa pode contribuir para } \\
\text { melhorar a saúde e a qualidade de } \\
\text { vida do trabalhador. Na percepção dos } \\
\text { trabalhadores, a ginástica laboral ajuda } \\
\text { a prevenir doenças, a melhorar o } \\
\text { humor, a diminuir tensões e estresse, e } \\
\text { a aumentar a produtividade. } \\
\text { Entretanto, observa-se que, para que o } \\
\text { programa possa ser efetivo, deveria } \\
\text { ser associado à organização do } \\
\text { trabalho, o que não ocorre nessa } \\
\text { empresa. }\end{array}$ \\
\hline 2003 & $\begin{array}{l}\text { CARANDIN } \\
\text { A, D. M. }\end{array}$ & $\begin{array}{l}\text { Qualidade de vida no } \\
\text { trabalho: construção e } \\
\text { validação de um } \\
\text { instrumento de medida } \\
\text { para enfermeiras }\end{array}$ & $\begin{array}{l}\text { Doutorado } \\
\text { Enfermagem } \\
\text { /USP }\end{array}$ & $\begin{array}{l}\text { QVT e } \\
\text { Instrumento } \\
\text { de Medida }\end{array}$ & $\begin{array}{l}\text { Enfermeiras } \\
\text { de } 4 \\
\text { hospitais da } \\
\text { cidade de } \\
\text { SP }\end{array}$ & $\begin{array}{l}\text { Trata-se de um estudo de } \\
\text { desenvolvimento metodológico que teve } \\
\text { por objetivo construir e validar um } \\
\text { instrumento para medir a QVT de } \\
\text { enfermeiras. }\end{array}$ & $\begin{array}{l}\text { Fernandes } \\
\text { (1992) }\end{array}$ & $\begin{array}{l}\text { Este estudo resultou na criação de um } \\
\text { instrumento composto por } 65 \text { itens e } \\
13 \text { domínios, com índices de } \\
\text { confiabilidade altamente satisfatórios. }\end{array}$ \\
\hline 2003 & $\begin{array}{l}\text { PENTEAD } \\
\text { O, R. Z. }\end{array}$ & $\begin{array}{l}\text { Aspectos de qualidade de } \\
\text { vida e de subjetividade na } \\
\text { promoção da saúde vocal } \\
\text { do professor }\end{array}$ & $\begin{array}{l}\text { Doutorado } \\
\text { Saúde } \\
\text { Pública/USP }\end{array}$ & $\begin{array}{l}\text { QVTe } \\
\text { Saúde } \\
\text { vocal }\end{array}$ & Professor & $\begin{array}{l}\text { Investigar as relações entre qualidade de } \\
\text { vida e saúde vocal do professor. }\end{array}$ & $\begin{array}{l}\text { Triangulação de } \\
\text { Instrumentos } \\
\text { que medem } \\
\text { QVT }\end{array}$ & $\begin{array}{l}\text { Os dados mostram a relação entre } \\
\text { qualidade de vida e voz/saúde em } \\
\text { diversos aspectos da vida cotidiana. As } \\
\text { condições e organização do trabalho } \\
\text { docente apresentam problemas que } \\
\text { atingem o ato educativo, a } \\
\text { subjetividade e o processo saúde- } \\
\text { doença do professor e demandam } \\
\text { ações para Promoção da Saúde na } \\
\text { escola. }\end{array}$ \\
\hline 2002 & $\begin{array}{l}\text { BRIGHENTI } \\
\text {, G. C.; } \\
\text { SILVA, A. }\end{array}$ & $\begin{array}{l}\text { Qualidade de vida no } \\
\text { trabalho: um estudo dos } \\
\text { fatores e dimensões }\end{array}$ & $\begin{array}{l}\text { Artigo } \\
\text { ENANPAD }\end{array}$ & QVT & $\begin{array}{l}\text { Atendentes } \\
\text { da Central } \\
\text { de }\end{array}$ & $\begin{array}{l}\text { Avaliar os indicadores de qualidade de } \\
\text { vida no trabalho na percepção dos } \\
\text { empregados lotados na Central de }\end{array}$ & $\begin{array}{l}\text { Fernandes } \\
\text { (1996) a partir } \\
\text { de Walton }\end{array}$ & $\begin{array}{l}\text { Evidenciou-se que fatores como } \\
\text { participação e liberdade de expressão, } \\
\text { oportunidade de utilização e }\end{array}$ \\
\hline
\end{tabular}




\begin{tabular}{|c|c|c|c|c|c|c|c|c|}
\hline Ano & Autor & Título & Natureza & Tema & Foco & Objetivo & $\begin{array}{l}\text { Modelo } \\
\text { Teórico }\end{array}$ & Resultados \\
\hline & $\begin{array}{l}\text { B.; } \\
\text { FERNAND } \\
\text { ES, C. B. }\end{array}$ & $\begin{array}{l}\text { presentes e percebidas na } \\
\text { central de relacionamento } \\
\text { com os clientes da TIM } \\
\text { celular de Santa Catarina }\end{array}$ & & & $\begin{array}{l}\text { Relacionam } \\
\text { ento com } \\
\text { Clientes }\end{array}$ & $\begin{array}{l}\text { Relacionamento com os Clientes de } \\
\text { Santa Catarina. }\end{array}$ & $\begin{array}{l}\text { (1973) e } \\
\text { Westley (1979) }\end{array}$ & $\begin{array}{l}\text { desenvolvimento das capacidades, } \\
\text { saúde, segurança e bem-estar no } \\
\text { trabalho, merecem uma maior atenção } \\
\text { por parte da empresa. }\end{array}$ \\
\hline 2002 & $\begin{array}{l}\text { GUEIROS, } \\
\text { M. G., } \\
\text { OLIVEIRA, } \\
\text { L. M. B. }\end{array}$ & $\begin{array}{l}\text { Qualidade de vida no } \\
\text { trabalho: um estudo no } \\
\text { setor de hotelaria na } \\
\text { Região Metropolitana do } \\
\text { Recife }\end{array}$ & $\begin{array}{l}\text { Artigo } \\
\text { ENANPAD }\end{array}$ & $\begin{array}{l}\text { Qualidade } \\
\text { de Vida no } \\
\text { Trabalho e } \\
\text { Satisfação }\end{array}$ & $\begin{array}{l}\text { Funcionários } \\
\text { de hotéis do } \\
\text { Grande } \\
\text { Recife }\end{array}$ & $\begin{array}{l}\text { Apresentar resultados relativos à } \\
\text { satisfação dos funcionários de hotéis do } \\
\text { Grande Recife com as políticas de RH e, } \\
\text { entre estas, aquelas referentes à } \\
\text { qualidade de vida no trabalho. }\end{array}$ & $\begin{array}{l}\text { Combinação de } \\
\text { conceitos }\end{array}$ & $\begin{array}{l}\text { Os hotéis pesquisados apresentaram } \\
\text { níveis consideráveis de satisfação dos } \\
\text { empregados em relação a estas } \\
\text { políticas. }\end{array}$ \\
\hline 2002 & $\begin{array}{l}\text { PICCININI, } \\
\text { V. C., } \\
\text { OLIVEIRA, } \\
\text { S. R. }\end{array}$ & $\begin{array}{l}\text { Flexibilização, Qualidade } \\
\text { de Vida e } \\
\text { Empregabilidade: } \\
\text { O Caso das Cooperativas } \\
\text { de Trabalho de Porto } \\
\text { Alegre }\end{array}$ & $\begin{array}{l}\text { Artigo } \\
\text { ENANPAD }\end{array}$ & $\begin{array}{l}\text { QVT, } \\
\text { Flexibilizaç } \\
\text { ão e } \\
\text { Empregabili } \\
\text { dade }\end{array}$ & $\begin{array}{l}\text { Especialista } \\
\text { s e } \\
\text { dirigentes de } \\
\text { cooperativas }\end{array}$ & $\begin{array}{l}\text { Questionando-se quanto à flexibilização } \\
\text { das condições e das relações de } \\
\text { trabalho e qualidade de vida nas } \\
\text { Cooperativas de Trabalho de Porto } \\
\text { Alegre. }\end{array}$ & $\begin{array}{l}\text { QVT } \\
\text { envolvendo } \\
\text { questões de } \\
\text { emprego e } \\
\text { empregabilidad } \\
\text { e (inexistência } \\
\text { de um modelo } \\
\text { predominate) }\end{array}$ & $\begin{array}{l}\text { Foram entrevistados especialistas no } \\
\text { assunto e dirigentes dessas } \\
\text { cooperativas. Identificou-se, por parte } \\
\text { dos dirigentes, a valorização dos ideais } \\
\text { cooperativistas e a preocupação com a } \\
\text { qualidade de vida dos cooperados. }\end{array}$ \\
\hline 2002 & $\begin{array}{l}\text { ROCHA, S. } \\
\text { S. L. }\end{array}$ & $\begin{array}{l}\text { Qualidade de vida no } \\
\text { trabalho em enfermagem: } \\
\text { percepção de enfermeiros } \\
\text { docentes de uma } \\
\text { universidade privada }\end{array}$ & $\begin{array}{l}\text { Doutorado } \\
\text { Enfermagem } \\
\text { /USP }\end{array}$ & QVT & $\begin{array}{l}\text { Docentes de } \\
\text { enfermagem } \\
\text { de uma } \\
\text { instituição } \\
\text { de ensino } \\
\text { privada }\end{array}$ & $\begin{array}{l}\text { Caracterizar esses docentes quanto aos } \\
\text { dados pessoais e profissionais; conhecer } \\
\text { o significado da QVT docente e captar os } \\
\text { processos desgastantes e } \\
\text { potencializadores geradores de seus } \\
\text { perfis saúde-doença. }\end{array}$ & Breilh & $\begin{array}{l}\text { QVT significa ter condições de } \\
\text { trabalho, remuneração, relacionamento } \\
\text { interpessoal e identificação } \\
\text { profissional. }\end{array}$ \\
\hline 2002 & $\begin{array}{l}\text { SILVA, L. } \\
\text { V., } \\
\text { ANTUNES, } \\
\text { E. D. }\end{array}$ & $\begin{array}{l}\text { Influência das Relações } \\
\text { Flexíveis de Trabalho na } \\
\text { Qualidade de Vida do } \\
\text { Trabalhador: a } \\
\text { visão de seus atores } \\
\text { sociais }\end{array}$ & $\begin{array}{l}\text { Artigo } \\
\text { ENANPAD }\end{array}$ & $\begin{array}{l}\text { QVT e } \\
\text { Flexibilizaç } \\
\text { ão }\end{array}$ & $\begin{array}{l}\text { Gerentes, } \\
\text { trabalhadore } \\
\text { s estáveis e } \\
\text { flexibilizados } \\
\text { da Empresa, } \\
\text { e } \\
\text { representant } \\
\text { e do } \\
\text { sindicato } \\
\text { dos } \\
\text { trabalhadore } \\
\mathrm{s}\end{array}$ & $\begin{array}{l}\text { Percepção que os atores sociais têm } \\
\text { quanto à influência de alguns tipos de } \\
\text { flexibilização do trabalho na Qualidade } \\
\text { de Vida dos Trabalhadores }\end{array}$ & $\begin{array}{l}\text { Combinação de } \\
\text { conceitos de } \\
\text { QVT e } \\
\text { flexibilização }\end{array}$ & $\begin{array}{l}\text { Verificou-se que, para os gerentes, a } \\
\text { flexibilização das relações de trabalho } \\
\text { é uma tendência que tem implicações } \\
\text { positivas na vida dos trabalhadores. } \\
\text { Para os trabalhadores estáveis e } \\
\text { flexibilizados, alguns tipos de } \\
\text { flexibilização são positivos para a } \\
\text { qualidade de vida do trabalhador, em } \\
\text { particular, quando aparecem como } \\
\text { alternativas frente ao desemprego e à } \\
\text { empregabilidade. Para o sindicato dos } \\
\text { trabalhadores, a flexibilização das } \\
\text { relações de trabalho influencia } \\
\text { negativamente na qualidade de vida do } \\
\text { trabalhador, sendo associada } \\
\text { predominantemente à perda de direitos } \\
\text { trabalhistas. }\end{array}$ \\
\hline 2001 & $\begin{array}{l}\text { COSTA, I. } \\
\text { F.; } \\
\text { LIMONGI- } \\
\text { FRANÇA, } \\
\text { A. C. }\end{array}$ & $\begin{array}{l}\text { Qualidade de vida no } \\
\text { trabalho: o estudo } \\
\text { qualitativo na empresa } \\
\text { Natura }\end{array}$ & $\begin{array}{l}\text { Artigo } \\
\text { SEMEAD }\end{array}$ & QVT & $\begin{array}{l}\text { Funcionários } \\
\text { da Empresa } \\
\text { Natura }\end{array}$ & $\begin{array}{l}\text { Estudar um programa empresarial, } \\
\text { buscando compreender o envolvimento } \\
\text { dos empregados inseridos nos } \\
\text { Programas de Qualidade de Vida no } \\
\text { Trabalho, bem como as transformações } \\
\text { no seu estilo de vida. }\end{array}$ & $\begin{array}{l}\text { Max Pagès no } \\
\text { seu estudo } \\
\text { sobre o Poder } \\
\text { das } \\
\text { Organizações }\end{array}$ & $\begin{array}{l}\text { Identificando e buscando as } \\
\text { contradições entre o discurso da } \\
\text { direção e a realidade vivenciada pelos } \\
\text { trabalhadores, percebeu-se nos } \\
\text { relatos, pelo menos na empresa } \\
\text { escolhida, que os empregados }\end{array}$ \\
\hline
\end{tabular}




\begin{tabular}{|c|c|c|c|c|c|c|c|c|}
\hline Ano & Autor & Título & Natureza & Tema & Foco & Objetivo & $\begin{array}{l}\text { Modelo } \\
\text { Teórico }\end{array}$ & Resultados \\
\hline & & & & & & & & $\begin{array}{l}\text { incorporam os objetivos da } \\
\text { organização e o Programa de } \\
\text { Qualidade de Vida. }\end{array}$ \\
\hline 2001 & $\begin{array}{l}\text { DINIZ, M. } \\
\text { G. }\end{array}$ & $\begin{array}{l}\text { Fatores Ergonômicos das } \\
\text { Condições de Trabalho e } \\
\text { a Qualidade de Vida no } \\
\text { Trabalho no Setor de } \\
\text { Transportes Urbanos } \\
\text { Rodoviários: Estudo dos } \\
\text { Casos de Campina } \\
\text { Grande e Lisboa }\end{array}$ & $\begin{array}{l}\text { Artigo } \\
\text { ENANPAD }\end{array}$ & $\begin{array}{l}\text { Qualidade } \\
\text { de Vida no } \\
\text { Trabalho e } \\
\text { Ergonomia }\end{array}$ & $\begin{array}{l}\text { Motoristas } \\
\text { do } \\
\text { transporte } \\
\text { urbano }\end{array}$ & $\begin{array}{l}\text { Identificar os fatores ergonômicos das } \\
\text { condições de trabalho que, quando } \\
\text { favoráveis, poderão contribuir para } \\
\text { melhorar a qualidade de vida no trabalho } \\
\text { do motorista do transporte urbano de } \\
\text { Campina Grande e de Lisboa. }\end{array}$ & $\begin{array}{l}\text { Modelo Sato } \\
\text { (1991) }\end{array}$ & $\begin{array}{l}\text { Alguns fatores, sob os quais o trabalho } \\
\text { é desenvolvido, requerem intervenções } \\
\text { ergonômicas. A maioria disse sentir } \\
\text { fadiga, mais mental do que física, } \\
\text { sendo o trânsito apontado como } \\
\text { principal agente. Como atenuante, } \\
\text { contam com a adaptação. À luz da } \\
\text { penosidade, embora presente em sua } \\
\text { qualidade de vida no trabalho, o } \\
\text { sofrimento do motorista não ultrapassa } \\
\text { o limite do suportável. }\end{array}$ \\
\hline 2000 & $\begin{array}{l}\text { ALBERTO, } \\
\text { L. C. F. R. }\end{array}$ & $\begin{array}{l}\text { Os Determinantes da } \\
\text { Felicidade no Trabalho: } \\
\text { Um Estudo Sobre a } \\
\text { Diversidade nas } \\
\text { Trajetórias Profissionais } \\
\text { de Engenheiros } \\
\end{array}$ & $\begin{array}{l}\text { Mestrado - } \\
\text { IP/USP }\end{array}$ & $\begin{array}{l}\text { QVT e } \\
\text { Trajetória } \\
\text { de Carreira }\end{array}$ & $\begin{array}{l}\text { Engenheiros } \\
\text { entre } 28 \text { e } \\
45 \text { anos de } \\
\text { idade }\end{array}$ & $\begin{array}{l}\text { O trabalho busca compreender as } \\
\text { pressões de ordem psicológica, } \\
\text { ideológica, social e econômica e outros } \\
\text { fatores determinantes na felicidade no } \\
\text { trabalho do profissional de engenharia. }\end{array}$ & $\begin{array}{l}\text { Não utilizou } \\
\text { nenhum em } \\
\text { específico }\end{array}$ & $\begin{array}{l}\text { Observou-se que o trabalho é } \\
\text { importante para os indivíduos, sendo } \\
\text { caracterizado por uma relação } \\
\text { emocional que possibilita a felicidade } \\
\text { em momentos específicos e fases da } \\
\text { carreira. }\end{array}$ \\
\hline 2000 & $\begin{array}{l}\text { BENAVIDE } \\
\text { S, S. S. }\end{array}$ & $\begin{array}{l}\text { Qualidade de Vida no } \\
\text { Trabalho e a Gestão } \\
\text { Estratégica de Recursos } \\
\text { Humanos: o Projeto } \\
\text { Vivendo Bem da Van Den } \\
\text { Bergh }\end{array}$ & $\begin{array}{l}\text { Mestrado } \\
\text { FEA/USP }\end{array}$ & $\begin{array}{l}\text { QVT e } \\
\text { Gestão } \\
\text { Estratégica } \\
\text { de RH }\end{array}$ & $\begin{array}{l}\text { Funcionários } \\
\text { da empresa } \\
\text { Van Den } \\
\text { Bergh }\end{array}$ & $\begin{array}{l}\text { A pesquisa buscou levantar as opiniões } \\
\text { e os sentimentos dos funcionários, } \\
\text { identificando suas necessidades no } \\
\text { intuito de desenvolver critérios para a } \\
\text { melhoria da Qualidade de Vida no } \\
\text { Trabalho através do programa "Vivendo } \\
\text { Bem". }\end{array}$ & $\begin{array}{l}\text { Não utilizou } \\
\text { nenhum em } \\
\text { específico }\end{array}$ & $\begin{array}{l}\text { Os resultados e as conclusões deste } \\
\text { trabalho, apesar de não generalizáveis, } \\
\text { oferecem indicações para sugerir que } \\
\text { investir na qualidade de vida das } \\
\text { pessoas é criar condições favoráveis } \\
\text { para alcançar os objetivos estratégicos } \\
\text { da organização. }\end{array}$ \\
\hline 2000 & $\begin{array}{l}\text { COELHO, } \\
\text { J. A. }\end{array}$ & $\begin{array}{l}\text { Organização e Carreiras } \\
\text { sem Fronteiras: a } \\
\text { percepção de formandos } \\
\text { sobre a tendência nas } \\
\text { exigências profissionais }\end{array}$ & $\begin{array}{l}\text { Mestrado - } \\
\text { IP/USP }\end{array}$ & Carreira & $\begin{array}{l}\text { Alunos do } \\
\text { último ano } \\
\text { de sete } \\
\text { cursos de } \\
\text { nível } \\
\text { superior } \\
\text { (Administraç } \\
\text { ão, Ciências } \\
\text { Contábeis, } \\
\text { Direito,Enge } \\
\text { nharia, } \\
\text { Psicologia, } \\
\text { Comunicaçã } \\
\text { o Social e } \\
\text { Processame } \\
\text { nto de } \\
\text { Dados) }\end{array}$ & $\begin{array}{l}\text { Estuda os efeitos das transformações } \\
\text { que ocorreram nas organizações e no } \\
\text { conceito de carreira a partir das } \\
\text { mudanças econômicas e do novo } \\
\text { significado de trabalho. Analisa o } \\
\text { conceito de carreira sem fronteiras e } \\
\text { investiga a percepção de formandos } \\
\text { sobre as tendências nas exigências } \\
\text { profissionais e as atuais condições de } \\
\text { trabalho. }\end{array}$ & $\begin{array}{l}\text { Não utilizou } \\
\text { nenhum em } \\
\text { específico }\end{array}$ & $\begin{array}{l}\text { Os resultados evidenciaram que os } \\
\text { jovens formandos percebem as } \\
\text { tendências em relação às exigências } \\
\text { profissionais, assim como a } \\
\text { necessidade de maior flexibilidade, } \\
\text { disponibilidade e compromisso. Por } \\
\text { outro lado, um grupo de jovens não } \\
\text { está se preparando para enfrentar } \\
\text { mudanças. Não define novas regras de } \\
\text { sucesso ou relação de qualidades, } \\
\text { porém enfatiza a atitude proativa do } \\
\text { indivíduo nos diferentes papéis que } \\
\text { exerce na vida como condição para se } \\
\text { adaptar ao mundo globalizado. }\end{array}$ \\
\hline 2000 & $\begin{array}{l}\text { GELVES } \\
\text { PEÑA, J. S. }\end{array}$ & $\begin{array}{l}\text { O âmago de um espinho } \\
\text { adormecido: análise da }\end{array}$ & $\begin{array}{l}\text { Mestrado } \\
\text { FEA/USP }\end{array}$ & $\begin{array}{l}\text { Gestão da } \\
\text { QVT }\end{array}$ & $\begin{array}{l}\text { Trabalhador } \\
\text { es da saúde }\end{array}$ & $\begin{array}{l}\text { A pesquisa procurou dar contribuições à } \\
\text { gestão de Qualidade de Vida no }\end{array}$ & $\begin{array}{l}\text { Não utilizou } \\
\text { nenhum em }\end{array}$ & $\begin{array}{l}\text { Observou-se uma deficiência em } \\
\text { várias facetas das dinâmicas sociais }\end{array}$ \\
\hline
\end{tabular}




\begin{tabular}{|c|c|c|c|c|c|c|c|c|}
\hline Ano & Autor & Título & Natureza & Tema & Foco & Objetivo & $\begin{array}{l}\text { Modelo } \\
\text { Teórico }\end{array}$ & Resultados \\
\hline & & $\begin{array}{l}\text { gestão de qualidade de } \\
\text { vida no trabalho em um } \\
\text { hospital psiquiátrico } \\
\text { público }\end{array}$ & & & & $\begin{array}{l}\text { Trabalho - QVT através do resgate das } \\
\text { ações e dos programas de gestão de } \\
\text { pessoas encontrados nas políticas de } \\
\text { saúde pública }\end{array}$ & específico & $\begin{array}{l}\text { no ambiente de trabalho, como: a } \\
\text { dificuldade de criação de espaços } \\
\text { participativos; a falta de liberdade e } \\
\text { criatividade no serviço; aprender a } \\
\text { pensar e a crescer em harmonia. }\end{array}$ \\
\hline 2000 & $\begin{array}{l}\text { LISONDO, } \\
\text { H. R. }\end{array}$ & $\begin{array}{l}\text { Qualidade Dialética: } \\
\text { Motivação, Mudança e } \\
\text { Resistências. }\end{array}$ & $\begin{array}{l}\text { Doutorado - } \\
\text { EP/USP }\end{array}$ & $\begin{array}{l}\text { Motivação e } \\
\text { Mudança } \\
\text { organizacio } \\
\text { nal }\end{array}$ & $\begin{array}{l}\text { Trabalhador } \\
\text { es de } \\
\text { pequenas e } \\
\text { médias } \\
\text { empresas }\end{array}$ & $\begin{array}{l}\text { Auxiliar na resolução de conflitos e a } \\
\text { implantação de sistemas de qualidade } \\
\text { em pequenas e médias empresas. }\end{array}$ & $\begin{array}{l}\text { Conceito de } \\
\text { saber profundo } \\
\text { de Deming }\end{array}$ & $\begin{array}{l}\text { Contribuir para a expansão do } \\
\text { pensamento da qualidade, } \\
\text { acrescentando-lhe a visão das ciências } \\
\text { negativas. }\end{array}$ \\
\hline
\end{tabular}




\subsubsection{Produtividade}

Moreira (1991) define que a produtividade de um sistema de produção é a relação daquilo que foi produzido e os insumos utilizados num determinado período de tempo.

Produtividade é aproveitar ao máximo os recursos disponíveis de modo que os resultados obtidos sejam altamente competitivos. A produtividade está associada a todo o conjunto de atividades de gestão, envolvendo o controle de processos, que por sua vez, inclui a cadeia produtiva, interações pessoa-trabalho e sobrevivência da empresa por meio da competitividade (Limongi-França, 2003).

A autora destaca ainda que a sociedade encontra-se na era do trabalhador do conhecimento e embora ainda existam poucos estudos a respeito da produtividade desse trabalhador, descreve fatores que Drucker (2000) determina em relação à produtividade do trabalhador do conhecimento: conhecer a tarefa que será realizada, a responsabilidade pela produtividade é do próprio trabalhador do conhecimento, a necessidade da inovação continuada, aprendizado e ensino contínuos para o trabalhador do conhecimento, importância para a qualidade e posição de um ativo (e não custo) que queira trabalhar para a organização.

A produtividade, especialmente no setor de serviços, por ser intrínseca às condições físicas, mentais e ambientais do mundo do trabalho, precisa ser entendida dentro das variáveis BPSO-96. No contexto organizacional, um ser biopsicossocial divide-se em:

potenciais biológicos: características físicas herdadas ou adquiridas: metabolismo, resistências, vulnerabilidade dos órgãos e sistemas; 
potenciais psicológicos: processos afetivos, emocionais, e de raciocínio; conscientes ou inconscientes;

potenciais sociais: valores, crenças, papel na família, no trabalho e em todos os grupos a que a pessoa pertence ou participa; meio-ambiente, localização geográfica, os quais respondem de maneira variada às condições de vida;

potenciais organizacionais: cultura, valores, hábitos, políticas, tecnologias, competências e mercado.

\subsubsection{Legitimidade}

De acordo com Houaiss et al. (2004, p.1736), o dicionário da Língua Portuguesa, legitimidade é o "caráter, estado ou qualidade do que é legítimo", sendo legítimo, aquilo que é “ditado, justificado, explicado pelo bom senso, pela razão; justo, razoável”. Milkovich \& Boudreau apud Limongi-França (2003) definem legitimidade como a aceitação de decisões pela maioria, respeitando os direitos das minorias, ou seja, direitos, deveres, decisões, comportamentos e atitudes individuais ou específicos devem ser aceitos e considerados.

Berger \& Luckmann (1978, p.128) referem-se à legitimação, destacando que ela "explica a ordem institucional outorgando validade cognoscitiva a seus significados objetivados. A legitimação justifica a ordem institucional dando dignidade normativa a seus imperativos práticos". Implica não somente na questão dos valores, mas na questão do conhecimento. Abordam os três níveis de legitimação, sendo eles: o primeiro nível diz respeito a todas as afirmações tradicionais simples; o segundo, contém proposições teóricas 
em forma rudimentar, tendo como exemplo os provérbios, as lendas e histórias populares; e o terceiro, contém teorias explícitas pelas quais um setor institucional é legitimado em termos de um corpo diferenciado de conhecimento. Devido à sua complexidade e diferenciação, são confiadas a um pessoal especializado que as transmitem por meio de procedimentos de iniciação formalizados. Existe ainda, um quarto nível dos universos simbólicos, que "são corpos de tradição teórica que integram diferentes áreas de significação e abrangem a ordem institucional em uma totalidade simbólica".

Saldanha apud Limongi-França (2003) define legitimidade como sendo a base de uma pretensão, opinião, relação, e pode estar relacionada à legalidade, porém, seu conceito vai além, podendo ser aquilo que é verdadeiro, genuíno, ultrapassando o plano normativo. Quando as ações vêm acompanhadas de um conjunto de outras ações capazes de realmente indicar que seu objetivo é abrangente, considera-se tal ação legítima.

\subsubsection{Perfil do Gestor}

Vive-se um momento em que as empresas e pessoas estão inseridas em ambientes altamente competitivos. Com isso, torna-se importante definir o perfil do gestor, de modo que o mesmo seja capaz de atender às demandas impostas, levando a sua organização à sobrevivência e possível destaque no mercado. No presente estudo, entende-se como gestor duas figuras nas instituições: o coordenador pedagógico e o diretor ou proprietário da unidade.

Alguns dados extraídos do MEC apud Limongi-França (2003) listam aspectos da formação do administrador como objetivos do curso e habilidades a serem avaliadas. 
- Objetivos do curso de Administração:

contribuir para o aprimoramento da formação do administrador, como cidadão e profissional, para que colabore na elevação das condições de vida em sociedade;

integrar um processo de avaliação mais amplo e continuado do curso de Administração, incentivando ações voltadas à melhoria da qualidade do ensino;

subsidiar o estabelecimento de novos parâmetros e o redirecionamento contínuo do processo de ensino-aprendizagem.

- Habilidades a serem avaliadas:

comunicação interpessoal, expressão correta nos documentos técnicos específicos e interpretação da realidade das organizações;

raciocínio lógico, crítico e analítico, operando com valores e formulações matemáticas e estabelecendo relações formais e causais entre fenômenos;

criatividade em face dos diferentes contextos organizacionais e sociais;

compreensão do todo administrativo, de modo integrado, sistêmico e estratégico, bem como de sua relação com o ambiente externo;

capacidade de lidar com modelos de gestão inovadores; 
resolução de problemas e desafios organizacionais com flexibilidade e adaptabilidade;

ordenamento de atividades e programas; identificação e dimensionamento de riscos para a tomada de decisões;

seleção de estratégias adequadas de ação, visando atender interesses interpessoais e institucionais;

seleção de procedimentos que privilegiem formas de atuação em prol de objetivos comuns.

Percebe-se que o primeiro objetivo destacado para o curso de administração refere-se à elevação das condições de vida em sociedade, o que reforça a afirmação de Limongi-França (2003), quando descreve que o perfil do gestor é o grande propulsor das competências e dos valores das organizações da era pós-industrial, viabilizando a gestão de QVT mais efetiva e consistente com as necessidades das pessoas e das empresas.

Segundo Andrade (1993), os diretores ou proprietários das unidades e coordenadores pedagógicos, são em geral, ex-professores, criando uma hierarquia que se repete cada vez que uma nova unidade é aberta, ou seja, o professor de hoje é o coordenador pedagógico de amanhã, que por sua vez, será o diretor ou proprietário da unidade. 


\subsubsection{Práticas e Valores}

Nas experiências vividas por Limongi-França (2003), notou-se que nem sempre será possível observar nas empresas programas formais na gestão da QVT com definição de critérios, procedimentos metodológicos e metas de gerenciamento. O que é possível observar são ações e programas que abrangem vários níveis de análise, como modelos de gestão inovadores e práticas organizacionais com resultados positivos do ponto de vista empresarial e pessoal que caracterizam a missão QVT na empresa.

André Fischer (2002, p. 30) destaca que existem alguns fatores que condicionam o modelo de gestão de pessoas: tecnologia adotada, estratégia de organização do trabalho, cultura organizacional, estrutura organizacional e os fatores externos. Ao realizar uma retrospectiva dos modelos de gestão, salienta que o modelo de gestão de pessoas articulado por Competências pode responder de maneira positiva a este ambiente de competitividade no qual "a busca e a internalização das competências essenciais definirão as empresas que estarão competindo pela arena de oportunidades do futuro". Dentro do discurso sobre Competências, as pessoas aparecem com maior freqüência, e ocupam, segundo Prahalad \& Hammel (1995), papel importante nos processos de mudança estratégica.

Considerando este ambiente de alta competição, os gestores têm adotado posturas direcionadas a melhorar os maus hábitos de alguns profissionais, como o fumo, álcool, dietas inadequadas, pois tais hábitos trazem maior absenteísmo, redução de produtividade e doenças diversas, entre elas o stress (Limongi-França, 2003). Em seu livro, Limongi-França (2003) destaca que ao rastrear as empresas que possuem algo relacionado à QVT, constatou que existem empresas que praticam, publicam, vendem, discutem e pesquisam sobre o assunto, gerando contribuições e avanços aos estudos sobre QVT. 


\subsubsection{Nova Competência Humana}

Fleury (2002, p. 55) define competências humanas como “um saber agir responsável e reconhecido que implica em mobilizar, integrar, transferir conhecimentos, recursos, habilidades, que agregue valor econômico à organização e valor social ao indivíduo". Dutra (2001) propõe que as competências essenciais se referem às entregas esperadas das pessoas que asseguram a continuidade e o crescimento da empresa ou do negócio, sendo identificadas com base em diferentes processos. Dentro de tais definições Limongi-França (2003) idealiza um modelo conceitual de novas competências, considerando elementos sustentados por disciplinas, valores e práticas que tratam de aspectos socioeconômicos, organizacionais e da condição da pessoa no trabalho. Destaca, ainda, que a nova competência tem focos em âmbitos da organização, do conhecimento, dos sistemas de informação e da expansão do conceito de administração, por meio da visão de interfaces.

Para Ferreira (1998), a globalização é um fenômeno cultural irreversível, por isso os profissionais de idiomas devem caracterizar-se como verdadeiros profissionais de línguas e culturas estrangeiras. A autora destaca as competências que são desejáveis ao professor de inglês: o profissional deve apresentar bacharelado ou licenciatura em Letras Modernas, Lingüística e Tradução, áreas por eles conscientemente escolhidas por gosto, vocação ou circunstâncias que os motivaram a seguir carreira. Além disso, é necessário possuir conhecimentos teóricos (teorias sobre aquisição da linguagem e da língua estrangeira, fonética/fonologia, correntes da lingüística, semiótica e semiologia, análise do discurso, etnografia da comunicação, história e teorias da tradução, evolução do ensino de idiomas, etc.); competências lingüísticas (domínio da língua materna e da língua estrangeira do ponto de vista gramatical, semântico, discursivo, etc.); conhecimentos e competências pedagógico- 
didáticos (conhecimento de métodos e metodologias para o ensino da língua estrangeira, capacidades e habilidades para organizar e transmitir um saber, para elaborar material didático e conceber atividades pedagógicas; compreensão do público-alvo, de suas necessidades e de suas estratégias de aprendizado, boa dicção, etc.); conhecimentos técnicos (capacidade de explorar novas tecnologias de ensino de Língua Estrangeira (LE), de compor glossários técnicos); conhecimentos sócio-culturais e competência intercultural (literatura comparada; história econômica e das mentalidades; antropologia social, artes).

No entanto, quando se faz referência aos cursos de idiomas, nota-se que, na prática nem todas as instituições contratam pessoas cuja formação profissional seja em Letras ou áreas afins; muitas delas acreditam ser suficiente ao professor dominar o idioma, pois o mesmo utilizará um método desenvolvido pela instituição, ou um livro didático. O próprio aluno valoriza o professor caso o mesmo tenha tido uma vivência internacional e não necessariamente a formação na área.

\subsection{A Abordagem Biopsicossocial}

A construção da QVT ocorre a partir do momento em que se olham as pessoas como um todo, o que pode ser chamado de enfoque biopsicossocial (BPSO-96).

Os potenciais biológicos estão ligados à condição física do ser humano. Ainda que o ser humano seja definido como um ser biopsicossocial, pode-se separar cada potencial de modo que, didaticamente, o entendimento seja possível. Abordam-se aqui as conseqüências provocadas em função de uma vida pouco focada para a qualidade, nos aspectos que afetam diretamente a parte física, como a alimentação, vida sedentária, tabagismo, alcoolismo, ergonomia. Uma má alimentação, acompanhada pela falta de exercícios físicos, fumo e álcool 
podem provocar as doenças coronarianas. Nas questões ergonômicas, e aqui, vale destacar que o conceito de ergonomia transcende às disposições físicas de móveis e equipamentos utilizados no trabalho. A Ergonomia é um conceito amplo (Guérin et al., 2001) que envolve inclusive questões de sentido do trabalho, porém, o foco da definição incidirá sob o aspecto físico da ergonomia. Pheasant (1991) definiu ergonomia como o estudo científico do trabalho humano, considerando os seres humanos ao desenho de objetos, sistemas e ambientes para seu uso. Procura adequar o trabalho ao trabalhador e o produto ao usuário. Leva em consideração disciplinas como medicina ocupacional, higiene ocupacional, psicologia ocupacional, engenharia de produção, gerenciamento de produção, envolvendo aspectos mentais e físicos relacionados ao trabalho.

Para Iida (1993), a ergonomia é o estudo da adaptação do trabalho ao homem. O trabalho aqui tem um conceito amplo, abrangendo não apenas os equipamentos utilizados para transformar os materiais, mas também toda a situação em que ocorre o relacionamento entre o homem e o trabalho. Envolve não somente o ambiente físico, mas também os aspectos organizacionais de como esse trabalho é programado e controlado para produzir os resultados desejados.

Por se tratar de um estudo com professores de inglês, cabe destacar os aspectos biológicos encontrados na profissão. O sindicato dos professores de São Paulo (SINPROSP) destaca algumas questões relativas à saúde deste profissional. O uso constante da voz, o trabalho realizado geralmente em pé e o uso de movimentos repetitivos na execução das tarefas, que envolvem, entre outras coisas, o quadro negro, giz e apagador. Mendes (1995) destaca as doenças profissionais, decorrentes de situações a que as pessoas são expostas. Os movimentos repetitivos, como o "vai e vem" para apagar a 
lousa, a manutenção do braço acima do nível do ombro quando o professor escreve no alto da lousa e o fato de ficar muito tempo em pé, podem ser considerados como fatores de risco. A idéia é verificar na prática se essas atividades, entre outras, colaboram para o desenvolvimento de doenças ocupacionais (Hurtado et al., 2002).

Houve uma evolução do conceito, ou seja, as 'doenças dos trabalhadores' passaram a ser as 'doenças profissionais', e depois as 'doenças relacionadas com o trabalho' e por fim, à ‘saúde do trabalhador', citando outros agentes causadores das doenças, como agentes químicos (chumbo, benzeno, mercúrio), físicos (ruído, frio, calor, radiações) e biológicos (origem ocupacional). A última lista de doenças profissionais foi revista em 1995, e já conta com mais de 29 doenças.

O professor é um profissional que tem como principal instrumento de trabalho a voz (Roy et al., 2004) e que, na maioria das vezes, convive com a seguinte situação (SINPROSP, 2004):

> Grande jornada de trabalho, acarretando o uso da voz por muitas horas seguidas;

> Excesso de trabalho, obrigando o professor a levar trabalho para casa, o que diminui o tempo de repouso e lazer desse profissional; 
$>$ Número excessivo de alunos em sala de aula, tendo o professor que aumentar a intensidade de sua voz para ser ouvido por todos;

$>$ Condições físicas de trabalho inadequadas, como salas de aula mal projetadas, ruído externo e interno à sala de aula, sala de professores com estrutura inadequada;

Falta de informações sobre cuidados com a saúde vocal na sua formação profissional.

Essas situações fazem com que o professor seja um dos profissionais que mais apresentam problemas vocais (Penteado, 2003). Freqüentemente possui as queixas de garganta "raspando e ardendo", de sensação de corpo estranho na garganta, de tensão no pescoço, de cansaço vocal, de voz mais fraca no final do dia, de alterações na qualidade vocal, entre outros sintomas que denunciam o uso inadequado das estruturas que produzem a voz e/ou o abuso vocal.

Os potencias psicológicos referem-se às emoções, afetos, motivos e lembranças, que no contexto organizacional apóiam-se nas questões de valorização do funcionário, desafios existentes e sistemas de participação. Cabe destacar o assédio moral, ou seja, a exposição dos trabalhadores a situações humilhantes e constrangedoras, repetitivas e prolongadas durante o exercício de suas funções, em que o chefe age através de condutas negativas, relações desumanas de longa duração, desestabilizando a relação da vítima com o ambiente de trabalho e a organização, fazendo com que a pessoa sinta-se forçada a desistir do emprego. 
Caracteriza-se pela degradação das condições de trabalho, atitudes e condutas negativas dos chefes em relação a seus subordinados, constituindo prejuízos práticos e emocionais para o trabalhador e a organização. A vítima é isolada do grupo sem explicações, passando ao descrédito diante do grupo. Os pares acabam por colaborar com tal situação, pois temem que se agirem de outra forma, eles é que serão as vítimas, e dessa forma, instaura-se o silêncio coletivo, enquanto a vítima vai gradativamente se desestabilizando, até perder sua autoestima. Os danos à saúde podem surgir sob a forma de depressão, palpitações, tremores, distúrbios do sono, hipertensão, distúrbios digestivos, dores generalizadas, alteração da libido, pensamentos ou tentativas de suicídios. Hirigoyen (2002) diferencia o que é assédio moral daquilo que não o é. Por exemplo, não é assédio moral o estresse, as virtudes do conflito, a gestão por injúria, as agressões pontuais, outras formas de violência, as más condições de trabalho e as imposições profissionais. O quadro 3.6 quantifica os sintomas que o assédio moral provoca à saúde.Quadro 3.6 - Sintomas do assédio moral na saúde $(\mathrm{n}=870)$

\begin{tabular}{|c|c|c|}
\hline Sintomas & Mulheres (\%) & Homens (\%) \\
\hline Crises de choro & 100 & - \\
\hline Dores generalizadas & 80 & 80 \\
\hline Palpitações, tremores & 80 & 40 \\
\hline Sentimento de inutilidade & 72 & 40 \\
\hline Insônia ou sonolência excessiva & 69,6 & 63,6 \\
\hline Depressão & 60 & 70 \\
\hline Diminuição da libido & 60 & 15 \\
\hline Sede de vingança & 50 & 100 \\
\hline Aumento da pressão arterial & 40 & 51,6 \\
\hline Dor de cabeça & 40 & 33,2 \\
\hline Distúrbios digestivos & 40 & 15 \\
\hline Tonturas & 22,3 & 3,2 \\
\hline Idéia de suicídio & 16,2 & 100 \\
\hline Falta de apetite & 13,6 & 2,1 \\
\hline Falta de ar & 10 & 30 \\
\hline Passa a beber & 5 & 63 \\
\hline Tentativa de suicídio & - & 18,3 \\
\hline
\end{tabular}

Fonte: Barreto, 2000

Outro aspecto a ser considerado quando se menciona a questão psicológica, é a noção do Contrato Psicológico de Trabalho. É necessário que tal contrato seja trabalhado de forma que os funcionários conheçam as expectativas da empresa e vice-versa, afinal, ele é o pacto de expectativas, subjetivo, entre o empregado e o empregador, onde existe interação e influência 
mútua: é um contrato informal, regido por um conjunto de expectativas de ambas as partes sobre as ações da outra parte, as quais determinam os comportamentos.

Pode-se inserir neste potencial a metáfora de Morgan (1996) quanto vê as organizações como prisões psíquicas. Descreve o mito da caverna narrado por Platão, enfatizando algumas situações em que o ser humano é prisioneiro: do sucesso, da acomodação organizacional e dos processos grupais. Tais situações geram momentos de insatisfação que vão se somando até culminarem em doenças que afetam a condição física do ser humano.

Devido às intensas atividades que tais profissionais desempenham, existe um grande índice da ocorrência do burnout, ou seja, de uma resposta emocional a situações de stress crônico em função de relações intensas, gerando sentimentos de frustração e decepção quando percebem que não será possível atingir a situação de realização, reconhecimento, boa situação econômica (Limongi-França \& Rodrigues, 2002).

Dados levantados pelo SINPROSP (2004), informam que a indisciplina dos alunos é algo que gera um desgaste emocional nesse profissional.

Os potenciais sociais referem-se aos valores, crenças, papel na família, no trabalho e em todos os grupos a que a pessoa pertence ou participa, além do meio-ambiente e localização geográfica. Os valores e crenças já se encontram enraizados no ser humano, e vão se manifestando através das interações sociais. Cada indivíduo representa um papel na sociedade. De acordo com Sennet (2000), conversar sobre identidade não faz sentido atualmente, pois o "novo capitalismo" trouxe a necessidade de sempre mudar o que se é, fazendo com que as pessoas assumam identidades de acordo com as narrativas vividas. Nesse 
contexto, causa-se na pessoa um conflito interno, acarretando prejuízos à sua saúde física e psicológica.

Outro aspecto a ser considerado no potencial social é a questão do meio-ambiente. Quando é mencionado o desenvolvimento sustentável, é necessário que se considere (Ministério do Meio Ambiente, 2004):

- padrão de desenvolvimento para o século XXI, apoiado pela sinergia da sustentabilidade ambiental, social e econômica;

- modelo de civilização em que predomine o equilíbrio ambiental e a justiça social entre as nações;

- o meio ambiente é uma consideração de primeira ordem, que deve romper com o desenvolvimento dominante, onde a predominância do econômico, dê lugar à sustentabilidade ampliada (ambiental e social).

Um último ponto a ser abordado na questão social diz respeito às questões de responsabilidade social. Rosa Fischer (2002) destaca que o desafio da cidadania para a gestão de recursos humanos é propiciar as condições e os recursos para que se desenvolva uma cultura de cidadania organizacional, e identificar a filosofia e os valores que sustentam a gestão das pessoas para verificar sua consistência com os princípios da cidadania.

Para este estudo, em se tratando do aspecto social, o professor é responsável por facilitar o processo de comunicação entre todos os participantes da aula juntamente com as 
atividades em classe. Além disso, ele é um participante independente dentro do grupo, pois organiza os recursos, conduz os procedimentos e atividades em aula e atua como pesquisador e aprendiz, contribuindo para a aprendizagem através de habilidades, conhecimentos e experiências próprias. Precisa ter disposição ou estar disposto a buscar conhecimentos diversos, não só de aspectos gramaticais mas também de questões culturais, sociais, políticas e econômicas. Dessa forma, estando na posição de educadores, é necessário que tais profissionais conheçam inclusive as questões do meio-ambiente e de cidadania.

Assim, levando em consideração as três ênfases (biológica, psicológica e social), pode-se considerar que os aspectos organizacionais referem-se às questões de imagem corporativa, inovação e tecnologia, sistemas de controle, movimentações e registros, programas de treinamento e desenvolvimento, gestão de carreira e outras atividades específicas das empresas, considerando-se especificidades da cultura e do ambiente organizacional.

Para os professores de inglês supõe-se que a imagem corporativa que sua instituição transmite exerce peso considerável na satisfação percebida no trabalho. Mais que isso, imagina-se o grande peso que os professores colocam nas relações internas, especialmente nas relações de trabalho, pois uma característica que tem se notado é que a grande maioria das escolas de idiomas que existe no mercado, contrata seus professores como profissionais autônomos, não lhes dando nenhuma garantia, como: número definido de horas trabalhadas, férias remuneradas, décimo-terceiro salário, fundo de garantia por tempo de serviço (FGTS), entre outros. 
Os aspectos relacionados à gestão de carreira são, em parte, de responsabilidade da organização. Dutra (2002) define que cabe à pessoa estabelecer o seu planejamento individual de carreira, e, por outro lado, cabe à empresa definir um sistema de administração de carreiras, que é composto das seguintes partes:

Princípios: representam compromissos acordados entre a empresa e as pessoas;

Estrutura de Carreira: define a sucessão de posições e seus requisitos de acesso;

Instrumentos de gestão: instrumentos que dão suporte à relação entre a pessoa e a empresa, por exemplo, a avaliação de desempenho;

Definição de Papéis: envolve definir a estratégia, definir o sistema de administração de carreiras e a metodologia de concepção, implementação e atualização do sistema.

Porém, a atividade dos professores de inglês não inclui unicamente fatores de risco. A flexibilidade de horário pode ser considerada positiva, pois o profissional tem a oportunidade de trabalhar em determinados horários que lhes permitam realizar outras atividades paralelamente, podendo aumentar ou reduzir sua carga de trabalho conforme suas necessidades. Neste caso, sua rotina é sentida como menos repetitiva, uma vez que pode optar por trabalhar em locais geograficamente diferentes, o que pode trazer alguma sensação de mudança ou fuga do trivial. Por trabalhar em diversas instituições, não sente toda a carga se em algum momento perder um dos trabalhos, pois terá o suporte dos outros. O quadro 3.7 exemplifica o que foi discutido. 
Quadro 3.7 - Variáveis qualitativas sobre o conceito de qualidade de vida no trabalho

\begin{tabular}{|c|c|c|c|}
\hline $\begin{array}{c}\text { Área de } \\
\text { Investigação }\end{array}$ & Significado de QVT & Melhorias & Dificuldades \\
\hline Biológica & $\begin{array}{l}\text { - Saúde } \\
\text { - Segurança } \\
\text { - Ausência de } \\
\text { acidentes }\end{array}$ & $\begin{array}{l}\text { - Sistema de alimentação } \\
\text { - Ginástica laboral } \\
\text { - Controle de doenças }\end{array}$ & $\begin{array}{l}\text { - Existência de tarefas perigosas } \\
\text { - Ausência por licenças médicas } \\
\text { - Necessidade de alimentação e } \\
\text { repouso }\end{array}$ \\
\hline Psicológica & $\begin{array}{l}\text { - Amor } \\
\text { - Paz } \\
\text { - Realização pessoal }\end{array}$ & $\begin{array}{l}\text { - Valorização do funcionário } \\
\text { - Desafios } \\
\text { - Sistema de participação }\end{array}$ & $\begin{array}{l}\text { - Cobrança excessiva de resultados } \\
\text { - Relacionamento entre os } \\
\text { empregados } \\
\text { - Falta de motivação e interesse }\end{array}$ \\
\hline Social & $\begin{array}{l}\text { - Confiança } \\
\text { - Amizade } \\
\text { - Responsabilidade }\end{array}$ & $\begin{array}{l}\text { - Educação para o trabalho } \\
\text { - Benefícios familiares } \\
\text { - Atividades culturais e } \\
\text { esportivas }\end{array}$ & $\begin{array}{l}\text { - Falta de qualificação de profissionais } \\
\text { - Condições culturais e econômicas } \\
\text { dos empregados } \\
\text { - Problemas familiares dos } \\
\text { empregados }\end{array}$ \\
\hline Organizacional & $\begin{array}{l}\text { - Investimento } \\
\text { - Humanismo } \\
\text { - Competitividade }\end{array}$ & $\begin{array}{l}\text { - Clareza nos } \\
\text { procedimentos } \\
\text { - Organização Geral } \\
\text { - Contato com o cliente }\end{array}$ & $\begin{array}{l}\text { - Processos de produção/tecnologia } \\
\text { - Pressão dos clientes } \\
\text { - Preparo da documentação }\end{array}$ \\
\hline
\end{tabular}

Fonte: Limongi-França, 1996

O quadro 3.8 ilustra a base teórica utilizada para a pesquisa, combinando o Modelo de Competências para a QVT com a Abordagem Biopsicossocial:

Quadro 3.8 - Modelo de competências para a QVT x Abordagem BPSO-96

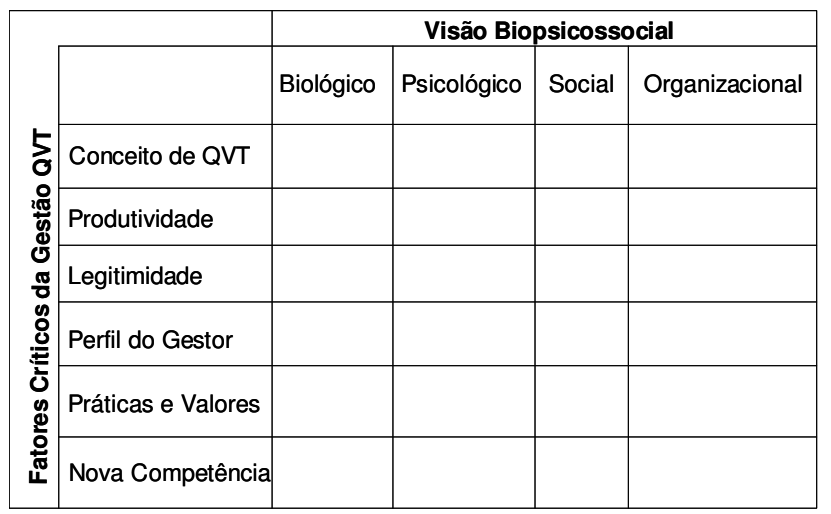

Fonte: a autora

\subsection{Administração de Empresas: aspectos estratégicos}

Diante dos modelos teóricos expostos e os aspectos biológicos, psicológicos, sociais que envolvem a organização, nota-se que as instituições que desejam implementar programas 
ou ações de QVT precisam enxergar a questão passando pelo nível estratégico da organização. Estratégia organizacional tem sido um tema constante na literatura sobre gestão. Albuquerque (2002) faz uma revisão da evolução do conceito a partir de 1965, destacando as principais abordagens ou escolas que vêm discutindo a questão. Embora as abordagens adotem perspectivas e conceitos distintos para a estratégia, vale ressaltar que são mais complementares do que conflitantes, conforme propõem Mintzberg et al. (2000), ao relembrar a fábula dos cegos e do elefante (em que cada cego descrevia uma parte diferente do animal). Albuquerque (2002) lista os vários aspectos da estratégia que resultam da análise dessas escolas: estratégia fornece direção; resulta de um processo de decisão; decisões são principalmente qualitativas e têm influência no longo prazo; abrange a organização e o seu ambiente; e envolve tanto conteúdo quanto processo em todos os níveis da organização.

Astely e Van de Ven (1983) observam que a abordagem estratégica em estudos organizacionais reconhece o ambiente em que se insere a organização e confere poder à gerência que, por meio de sua ação, modifica e define esse ambiente. A Teoria dos Recursos da Firma, em especial, sustenta que as organizações desenvolvem vantagens competitivas apenas quando, a partir de seus recursos, conseguem criar valor de maneira única, difícil de ser imitada (Barney, 1995). O foco para o posicionamento da firma deixa de ser externo, como pretende Porter (1996), e passa a ser interno.

Como conseqüência, encontra-se na literatura a noção de que as pessoas podem constituir um enorme potencial na organização, pois são capazes de gerar conhecimento, inovação e novos insights, que dão origem aos mais diversificados arranjos de recursos (Spender, 1996). Wright, Dunford e Snell (2001) acrescentam que, ao adotar a Teoria dos Recursos da Firma para a gestão de pessoas, a abordagem estratégica de Recursos Humanos, 
que ganha destaque a partir dos anos 80 , pressupõe, necessariamente que (i) uma determinada estratégia demanda um conjunto especial de comportamentos e atitudes dos empregados; e que (ii) certas políticas produzem um único conjunto de respostas dos empregados. Nesse sentido, políticas de Gestão de Pessoas seguem a estratégia escolhida para a organização (a maneira inversa seria muito mais difícil de ser conseguida). Além disso, o modelo de visão estratégica (Collins \& Porras, 1995), ao ser adotado por uma empresa, está baseado em uma ideologia central, ou seja, é necessário definir-se os valores centrais e o objetivo da organização. Os valores centrais são as doutrinas essenciais da empresa, representadas por um conjunto de princípios gerais de orientação; o objetivo é a razão fundamental pela qual a organização existe, aquilo que a guia permanentemente.

Um dos conceitos utilizados para se fazer a ponte entre estratégia e gestão estratégica de pessoas é o da competência essencial proposto por Prahalad \& Hamel (1998). A competência é definida pelos autores como a capacidade de combinar, misturar e integrar recursos em produtos e serviços, sendo a competência essencial, a combinação de recursos que traz a diferenciação da organização perante as demais. A competitividade de uma organização é determinada pela inter-relação dinâmica entre as competências organizacionais e a estratégia competitiva. Dessa maneira, a abordagem dos recursos faz o processo de formulação da estratégia e a formação de competências formar um círculo que se retroalimenta - as competências são formadas a partir de recursos e as estratégias são elaboradas a partir de grupos de recursos (competências essenciais); a implantação da estratégia gera novas configurações de recursos e novas competências que, por sua vez, irão influenciar novamente a formulação da estratégia (Fleury \& Lacombe, 2003). O modelo conceitual proposto por Limongi-França (2003) traz essa idéias de se desenvolver uma nova competência que esteja direcionada estrategicamente à gestão da QVT. 


\subsection{Cursos Livres de Idiomas}

Ao discutir a Abordagem BPSO-96, cria-se a necessidade de se discutir um pouco mais sobre o tipo de organização que é tratado nesse estudo. Cabe, neste caso, resgatar o surgimento dessas instituições, no cenário brasileiro.

A predominância do idioma inglês como língua estrangeira originou-se com a emergência econômica da Inglaterra no século XIX, estimulado pela Revolução Industrial, e a conseqüente expansão do colonialismo britânico; a seguir, com o poder político e militar dos EUA a partir da segunda guerra mundial, e à marcante influência econômica e cultural resultante, que deslocou o francês dos meios diplomáticos, passando a ser o inglês, o padrão das comunicações internacionais (Schütz, 2003).

O período monárquico marcou a introdução do ensino de "línguas vivas" nas escolas com a vinda da Família Real para o Brasil, em 1808 (Platero, 2000). Em 1855, regulamentouse o ensino de línguas modernas no nível secundário: assim, o francês, o inglês e o alemão passaram a ser obrigatórios durante três anos, juntamente com outras línguas que já eram oferecidas, latim e grego durante um ano, além do italiano durante um ano, facultativamente (Ferro apud Platero, 2000). A necessidade de se aprender uma língua estrangeira já era sentida nos cursos superiores de Direito, que além do latim, pedia-se o francês e o inglês. $\mathrm{O}$ curso de Medicina cobrava o latim, o francês ou o inglês e o alemão (Piletti apud Platero, 2000).

O tempo de estudo de uma língua estrangeira era de quatro a cinco horas no ensino secundário, mas reduziu-se pela metade no fim do Império devido ao poder de decisão 
centralizado pelas congregações dos colégios (Platero, 2000). No período republicano, com a determinação de um padrão único de ensino para línguas clássicas e modernas, diminuiu-se a carga semanal no ensino de línguas. Restou apenas o latim, o francês e o inglês ou alemão no ensino secundário (Ferro apud Platero, 2000). Por volta de 1931, após a criação do Ministério de Educação e Saúde Pública, ao diminuir a carga horária do latim, deu-se uma maior ênfase ao ensino de línguas modernas (Platero, 2000).

Algumas leis, juntamente com fatores econômicos e comodidade por parte das direções de escolas, modificaram o espaço ocupado pelas línguas estrangeiras, e somente uma língua estrangeira passou a ser obrigatória no segundo grau (Totis apud Platero, 2000).

A LDB (Lei de Diretrizes Básicas) traz no artigo 26, § $5^{\circ}$, a inclusão obrigatória de pelo menos uma língua estrangeira a partir da $5^{\mathrm{a}}$ série, ficando a cargo da comunidade escolar, escolher essa língua. Isso fez com que o ensino da língua estrangeira se tornasse fraco na educação fundamental, favorecendo o surgimento dos Cursos Livres de Idiomas. São assim chamados, pois seus certificados não são reconhecidos pelo Ministério da Educação e Cultura (MEC). A inexistência de um órgão que regulamente a abertura dos cursos de idiomas faz com que novos cursos e métodos apareçam diariamente.

Destacam-se os cursos de inglês na cidade de São Paulo, enfatizando que foram listados apenas alguns (Tabela 3.1) para se ter uma idéia de quanto se gasta mensalmente para estudar o idioma, selecionando as escolas tradicionais, cujo tempo de existência ultrapassa os 40 anos, e as recém-fundadas, cuja seleção baseou-se no critério utilizado pelo Instituto Franchising (2004), classificando as 20 maiores redes de 2002 (Tabela 3.2). 
Tabela 3.1 - Valor aproximado de um curso de Inglês na cidade de São Paulo

\begin{tabular}{|l|l|l|}
\hline Nome da escola & Ano de fundação & Valor aproximado de curso regular* $^{*}$ \\
\hline CCAA & 1961 & $\mathrm{R} \$ 728,00$ \\
\hline Wizard & 1982 & $\mathrm{R} \$ 840,00$ \\
\hline Escolas Fisk & 1958 & $\mathrm{R} \$ 875,00$ \\
\hline CNA & 1973 & $\mathrm{R} \$ 1020,00$ \\
\hline Cultura Inglesa & 1930 & $\mathrm{R} \$ 1.060,00$ \\
\hline União-Cultural & 1938 & $\mathrm{R} \$ 1.221,94$ \\
\hline CEL LEP & 1967 & $\mathrm{R} \$ 1.990,00$ \\
\hline Alumni & 1961 & $\mathrm{R} \$ 2.490,00$ \\
\hline
\end{tabular}

- (1 semestre, 2 aulas por semana)

Com esses dados, vê-se a dificuldade que as pessoas têm em aprender o idioma, cujo fator principal não reside necessariamente nos aspectos da língua em si, mas na questão financeira. Miramontes (2004) relata uma pesquisa onde 46\% dos entrevistados disseram não aprender o idioma por falta de recursos financeiros. O DIEESE, Departamento Intersindical de Estatística e Estudos Sócio-econômicos calcula mensalmente o salário mínimo necessário, que é o salário capaz de atender às necessidades de moradia, alimentação, educação, saúde, lazer, vestuário, higiene, transporte e previdência social. No mês de Junho de 2005, o valor deste salário foi de $\mathrm{R} \$ 1.538,56$, considerando uma família composta por dois adultos e duas crianças (DIEESE, 2005). Os dados do Instituto Brasileiro de Geografia e Estatística (IBGE, 2005) mostram que a renda média do trabalhador em maio de 2005 foi de $\mathrm{R} \$ 932,80$, valor este que, se confrontado com o salário mínimo necessário, dá indícios da dificuldade financeira que existe para se estudar um idioma.

\footnotetext{
${ }^{2}$ Levantamentos foram realizados por telefone, em nov/04. A grosso modo, os dados referem-se à semestralidade, cabendo destacar que cada instituição apresenta uma forma particular de cobrança.
} 
Tabela 3.2 - Maiores redes de franquias de 2002

\begin{tabular}{|c|l|r|}
\hline Ranking & Nome Fantasia & Un. Franquias \\
\hline 1 & Midas Autocenter & 2.724 \\
\hline 2 & O Boticário & 2.003 \\
\hline 3 & Kumon & 1.500 \\
\hline 4 & Applebee's & 1.000 \\
\hline $\mathbf{5}$ & Wizard Idiomas & $\mathbf{9 6 1}$ \\
\hline 6 & L'aqua di Fiori & 807 \\
\hline $\mathbf{7}$ & CCAA & $\mathbf{7 8 0}$ \\
\hline 8 & Água de Cheiro & 728 \\
\hline 9 & Chlorophylla & 700 \\
\hline 10 & Rede de Drogarias Farmais & 700 \\
\hline 11 & Hai Franchising & 700 \\
\hline $\mathbf{1 2}$ & Escolas Fisk & $\mathbf{6 2 3}$ \\
\hline 13 & BR Mania & 434 \\
\hline 14 & Mecânica de Vidros & 413 \\
\hline 15 & Localiza System & 394 \\
\hline 16 & Elkar & 388 \\
\hline 17 & AMPM & 358 \\
\hline 18 & Anglo Vestibulares & 350 \\
\hline 19 & Casa do Pão de Queijo & 341 \\
\hline $\mathbf{2 0}$ & CNA & $\mathbf{3 0 9}$ \\
\hline & &
\end{tabular}

A primeira escola de Inglês foi fundada em 1930. Desde então foram surgindo outras, e em breve levantamento (tabela 3.3), que inclui apenas os cursos que atualmente operam no sistema de franquias, nos últimos dez anos viu-se o surgimento de mais de 20 cursos, o que representa um número elevado considerando-se o crescimento percebido nos anos anteriores.

Uma hipótese que pode explicar o crescimento do número de redes no setor, diz respeito ao fato de ser um segmento de educação e treinamento, o que exige o desenvolvimento de métodos de ensino complexos, difíceis de serem desenvolvidos para uma unidade independente, fazendo com que o desenvolvimento e aprimoramento dos métodos de ensino sejam diluídos por toda a rede. 
Historicamente, também, é um dos segmentos mais antigos e conhecidos em franchising, com grandes redes. Educação e Treinamento é um segmento antigo e importante no franchising, com redes como Yázigi, CCAA, Skill, Wizard, entre outras (Instituto Franchising, 2004).

Outra hipótese que pode explicar tal fato envolve o próprio fenômeno da globalização, que se acentuou na década de 90, com a redução das barreiras comerciais, a expansão da liberalização comercial para serviços, propriedade intelectual e investimentos, direcionando as políticas brasileiras para a abertura de seus mercados às importações e não na promoção de exportações, gerando o desemprego (Stiglitz, 2003). Com isso, muitas pessoas encontraram-se diante da possibilidade e necessidade de abrir negócios próprios. 
Tabela 3.3 - Franquias cadastradas no Instituto Franchising

\begin{tabular}{|c|c|c|}
\hline Escola & $\begin{array}{c}\text { Ano de } \\
\text { Fundação }\end{array}$ & $\begin{array}{l}\text { Início das } \\
\text { Franquias }\end{array}$ \\
\hline Yázigi Internexus & 1950 & 1963 \\
\hline Escolas Fisk & 1958 & 1967 \\
\hline CCAA & 1961 & 1969 \\
\hline Pbf - Pink and Blue Freedom & 1965 & 1975 \\
\hline Red Balloon - Inglês p/ Crianças & 1969 & 1999 \\
\hline SKILL inglês • espanhol & 1973 & 1985 \\
\hline CNA & 1973 & 1987 \\
\hline Number One Idiomas & 1973 & 1991 \\
\hline Cambridge School of English & 1975 & 1994 \\
\hline ABC- American Brazilian Center & 1977 & 1994 \\
\hline Berlitz Franchising do Brasil & 1978 & 1996 \\
\hline Wizard Idiomas & 1982 & 1987 \\
\hline Quatrum English Schools & 1983 & 1990 \\
\hline Centro Cultural Americano de Idiomas & 1983 & 1995 \\
\hline The Kids Club - Inglês só p/ Crianças & 1987 & 1990 \\
\hline Seven - Inglês e Espanhol & 1987 & 1996 \\
\hline High Point Inglês e Espanhol & 1989 & 2001 \\
\hline CCI Franquias & 1992 & 1992 \\
\hline Mai English & 1992 & 1992 \\
\hline Keynote Music Center & 1992 & 1994 \\
\hline Feedback & 1993 & 1993 \\
\hline Excel Escola de Idiomas & 1993 & 1998 \\
\hline Wisdom & 1994 & 1994 \\
\hline Oxbridge Customised Courses & 1995 & 1995 \\
\hline Learning Fun & 1995 & 1997 \\
\hline Mádrassy Idiomas & 1995 & 2000 \\
\hline Skywards & 1995 & 2000 \\
\hline Top Teaching & 1997 & 2000 \\
\hline Planet Idiomas & 1998 & 1999 \\
\hline USA International & 1998 & 2003 \\
\hline Wall Street Institute & 1999 & 1999 \\
\hline Americas & 1999 & 2003 \\
\hline ALL- Alternative Language Lear & 2000 & 2000 \\
\hline Alps & 2001 & 2001 \\
\hline
\end{tabular}

Fonte: adaptado de www.guiadefranquias.com.br, acesso em 19/05/2005

O gráfico 3.1 procura ilustrar os períodos em que houve a fundação das escolas de idiomas. A idéia é mostrar o avanço na década de 90, considerando as muitas escolas que 
foram fundadas neste período. Isso significa que, de modo geral, à medida que as escolas foram fundadas, alguns anos depois passavam a operar sob o sistema de franquias.

Gráfico 3.1 - Taxa de Variação das Franquias por período (\%)

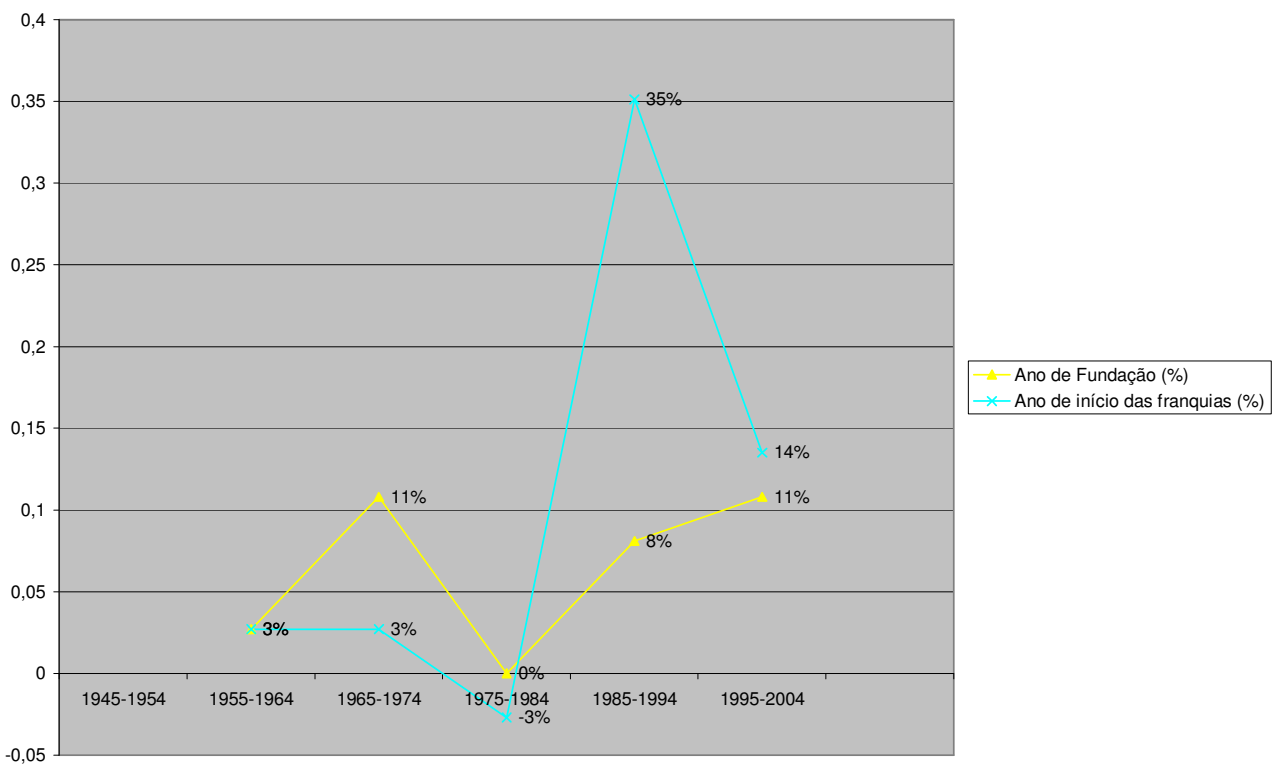

De acordo com dados do Sebrae (Tabela 3.4), o setor de Educação cresceu e está entre os 10 maiores segmentos de atividade. Neste contexto, poder-se-ia fazer uma breve comparação com as micro e pequenas empresas (MPE), que apesar de não se enquadrarem na condição de franquias, apresentam crescimento similar.

Tabela 3.4- Comparativo dos segmentos de atividade em Serviços (dez/97 e dez/99)

\begin{tabular}{|c|c|c|c|}
\hline \multicolumn{4}{|c|}{ Dez/97 } \\
\hline \multicolumn{2}{|c|}{ Segmentos de atividade } & MPEs & $\%$ \\
\hline 1 & Alojamento e alimentação & 86.455 & 25 \\
\hline 2 & Serv.asses.às empresas & 29.349 & 8 \\
\hline 3 & Saúde/Serviços Sociais & 21.994 & 6 \\
\hline 4 & Transporte Terrestre & 19.092 & 5 \\
\hline 5 & Atividades Recreativas & 15.257 & 4 \\
\hline 6 & Serviços Pessoais & 14.175 & 4 \\
\hline 7 & Atividades de informática & 13.782 & 4 \\
\hline 8 & Atividades imobiliárias & 12.796 & 4 \\
\hline 9 & Educação & 12.700 & 4 \\
\hline 10 & Agências de viagens & 3.148 & 1 \\
\hline \multicolumn{3}{|c|}{$\%$ acumulado nos 10 maiores segmentos } & 66 \\
\hline \multicolumn{2}{|c|}{ Total em serviços } & 347.954 & 100 \\
\hline
\end{tabular}

\begin{tabular}{|c|c|c|c|}
\hline \multicolumn{4}{|c|}{ Dez/99 } \\
\hline \multicolumn{2}{|c|}{ Segmentos de atividade } & MPEs & $\%$ \\
\hline 1 & Alojamento e alimentação & 96.965 & 24 \\
\hline 2 & Serv.asses.às empresas & 32.015 & 8 \\
\hline 3 & Transporte Terrestre & 24.599 & 6 \\
\hline 4 & Atividades de informática & 20.463 & 5 \\
\hline 5 & Saúde/Serviços Sociais & 20.340 & 5 \\
\hline 6 & Atividades Recreativas & 17.349 & 4 \\
\hline 7 & Educação & 15.099 & 4 \\
\hline 8 & Atividades imobiliárias & 13.803 & 3 \\
\hline 9 & Serviços Pessoais & 12.779 & 3 \\
\hline 10 & Agências de viagens & 3.693 & 1 \\
\hline \multicolumn{3}{|c|}{$\%$ acumulado nos 10 maiores segmentos } & 63 \\
\hline \multicolumn{2}{|c|}{ Total em serviços } & 405.040 & 100 \\
\hline
\end{tabular}

Fonte: Adaptado de CEE/MTE (dez/97 e dez/99) 
Embora as escolas de idiomas tenham se multiplicado nos últimos anos, devido cada vez mais, às menores barreiras para sua abertura (Andrade, 1993), cabe lembrar o que Carmagnani (2001) destaca quanto ao discurso publicitário das escolas de línguas estrangeiras, que visa reforçar os efeitos ideológicos produzidos por outros textos veiculados pela mídia sobre aprendizagem de línguas, mercado de trabalho e globalização. Não levam em consideração o discurso didático-pedagógico: a aprendizagem, os métodos e os profissionais são elementos secundários; há o foco dos fatores econômicos, emocionais e sociais ligados à aprendizagem de línguas.

\subsection{Os Professores de Inglês}

Muitas pessoas questionam sobre a definição de quem deve ou pode ser chamado de professor de inglês. De acordo com Sady (1996), as pessoas têm visões pessoais do que seja professor, estabelecida pela experiência prática. No Direito, não existe uma lei que defina tal profissional, por isso, para o direito do trabalho professor é aquele que se dedica ao exercício remunerado do magistério em estabelecimento particular de ensino, ou seja, os cursos que não dependem da autorização de órgãos públicos para funcionar, não necessariamente precisam de profissionais com habilitação para trabalhar em suas instituições. Os cursos livres caracterizam-se por não necessitar de autorização dos órgãos públicos de ensino para funcionar. Ainda, segundo este mesmo autor, ainda que não possua a habilitação, mas se a instituição que o contratou reconhecê-lo como professor, este deverá receber os direitos próprios daquele trabalho que o contrato determinar.

Dentro desta definição, que o professor é aquele que exerce a atividade de transmitir conhecimento (Sady, 1996), é possível perceber que o professor de inglês da atualidade, em 
geral, é jovem e carismático, não guardando nenhuma semelhança com o profissional do passado (Tippee, 2002). Entende-se como passado, o período no qual o magistério era visto na sociedade como uma atividade de caráter aristocrático (Sady, 1996). O dinamismo solicitado de um professor de inglês é alvo de muitos eventos e pesquisas, e são sempre mencionados os aspectos do desenvolvimento profissional, restando pouco sobre o profissional como ser humano (Leffa, 2001; Guimarães, 2004).

Em grande parte dos cursos, os profissionais são remunerados por hora-aula. A cada semestre, essas escolas de idiomas renovam seu quadro de professores, muito mais por desistência dos professores do que por vontade da escola possuindo, em muitos casos, somente a posição de um coordenador que atua a mais tempo na organização e se beneficia daquilo que é legalmente determinado. São poucos os professores que permanecem por mais de um ano na mesma instituição.

A literatura mostra uma escassez de fontes onde é possível buscar estatísticas sobre esses profissionais, o que torna um pouco difícil fornecer números que comprovem situações constatadas na prática. O sindicato dos professores de São Paulo (SINPROSP, 2004) possui alguns dados que revelam a situação de tais profissionais, como o piso salarial e alguns direitos que os professores possuem, destacados na tabela 3.5 a seguir:

Tabela 3.5 - Piso salarial $(\mathrm{R} \$)$

\begin{tabular}{|l|c|c|c|c|}
\hline & Out/02 a Mar/03 & Mar/03 até Jul/04 & Ago/04 a Fev/05 & \\
\hline Ed Infantil & 421,04 & 490,17 & 514,93 & ${ }^{*}$ \\
\hline Ed Infantil + fundamental ( $1^{\text {a }}$ a 4a) & 470,48 & 547,73 & 575,39 & ${ }^{*}$ \\
\hline Ens Fundamental ( 5a a 8a) & 5,56 & 6,47 & 6,80 & ${ }^{* *}$ \\
\hline Ensino Médio e Curso Livre & $\mathbf{6 , 1 9}$ & $\mathbf{7 , 2 1}$ & $\mathbf{7 , 5 7}$ & ${ }^{* *}$ \\
\hline Ensino Técnico & 5,64 & 6,57 & 6,90 & ${ }^{* *}$ \\
\hline Pré Vestibular & 8,64 & 10,06 & 10,57 & ${ }^{* *}$ \\
\hline
\end{tabular}

${ }^{*}$ acrescer $5 \%$ de hora atividade ${ }^{* *}$ acrescentar $1 / 6$ ( Descanso Semanal Remunerado) $+5 \%$ de hora atividade 
A remuneração, em geral, apresenta o salário-base, o descanso semanal remunerado (DSR) e a hora-atividade. Calcula-se o salário-base através da multiplicação do número de aulas semanais por 4,5 semanas, obtendo-se as aulas mensais, que por sua vez devem ser multiplicadas pelo valor hora-aula. $\mathrm{O}$ adicional de hora-atividade é o pagamento do tempo gasto pelo professor na preparação de aulas, preparação e correção de provas e exercícios. O Descanso Semanal Remunerado (DSR) corresponde a 1/6 sobre o salário-base, acrescido da hora-atividade. As horas extras, o adicional noturno, o adicional por tempo de serviço, a gratificação de função devem ser acrescidos de hora-atividade e DSR. Para que o professor tenha todos esses direitos, precisa ter carteira assinada, ou seja, ser registrado conforme a CLT. Além disso, Sady (1996) retoma a CLT e lembra que os professores de inglês não podem ser contratados por tempo determinado, pois o serviço dos professores nos estabelecimentos de ensino não deve ser visto como transitório, ou seja, os professores continuam a trabalhar em serviços complementares. De acordo com Carrion (apud Sady, 1996), os professores não podem ser contratados como autônomos, pois a relação jurídica dos alunos não se estabelece com o professor, mas sim, com a escola. Esse tipo de regime de trabalho é bastante praticado atualmente (Andrade, 1993). De acordo com Nogueira (2002, p. 129), essa "nova realidade, sintetizada na figura do trabalhador hifenizado (trabalho-parcial, trabalho-temporário, trabalho-casual, trabalho-por-conta-própria, trabalho-em-casa etc.), vem acompanhada, em geral, da precarização e degradação das condições de trabalho e renda."

Diante desse quadro, Gorz (2004, p.54), em uma nota de rodapé, pretende deixar claro que

nem toda atividade de serviço às pessoas é, uma atividade servil de venda de si, que só há venda de si quando a dádiva de si remunerada tem a própria remuneração por finalidade primária e submete-se à vontade de outrem. Os serviços profissionais - de auxílio e assistência, em particular - fornecidos no interesse de um outro não estão evidentemente neste caso. Pois, se o terapeuta, o enfermeiro, o professor agem no interesse das pessoas que lhes são confiadas, não agem contudo segundo a vontade e o prazer destas últimas. Devem, ao contrário, saber melhor que seu paciente, cliente 
ou aluno o que estes precisam e - é nisto que reside o seu profissionalismo - agir segundo uma deontologia e segundo certos procedimentos que lhes garantam o domínio de seus atos. É nos limites de uma relação balizada e objetivada por procedimentos profissionais que o terapeuta, o professor etc servem aos interesses ou necessidades dos outros. Não está ali para agradar e ainda retira a seus clientes o direito e a competência de definir o que lhe deve ser fornecido. Está em posição dominante. Seu profissionalismo, as regras dos procedimentos que aplica protegemno contra a personalização de suas relações com seus pacientes ou alunos e contra a cumplicidade, a compaixão, os laços afetivos estabelecidos entre eles. A remuneração de seus serviços contribui para manter a distância entre o prestador de serviço e seus pacientes ou alunos e a conferir um caráter relativamente impessoal a suas relações - ou a relativizar e a limitar a dimensão pessoal dessas relações (GORZ, 2004, p.54).

Visando aplicar a teoria em uma situação real, o próximo capítulo dedica-se a descrever os métodos e recursos que foram utilizados nesta pesquisa. 


\section{Capítulo 4 - Métodos e Recursos}

Quando se conduz uma pesquisa em ciências sociais, é possível que se encontre diversos métodos que caminham para a resposta do problema que se propõe. O conhecimento dos métodos de pesquisa permite ao pesquisador confiar nos resultados atingidos no estudo e saber se são aplicáveis à situação em questão. De acordo com Marconi \& Lakatos (1982), mesmo que os métodos científicos não obtenham respostas fidedignas, são os únicos que podem oferecer resultados satisfatórios.

As alternativas metodológicas mais tradicionais para se estudar os ambientes organizacionais são:

1. Exploratória: sua natureza é, essencialmente, "descobrir idéias e intuições" com métodos de pesquisa flexíveis, de modo que permita a consideração de muitos aspectos de um mesmo fenômeno (Marconi \& Lakatos, 2003; Mattar, 1996).

2. Descritiva: seu objetivo é apresentar as características de uma situação e verificar a frequiência com que este fenômeno ocorre (Selltiz, 1974).

3. Estudos causais: procuram verificar uma hipótese de relação causal entre variáveis (Kerlinger, 1980)

Nesta pesquisa, cujo objetivo principal foi estudar as percepções de QVT dos professores de inglês utilizando-se a abordagem BPSO-96 e o modelo de competências para a GQVT, foi realizado um estudo exploratório, pois a idéia, quando se utiliza tal estudo, 
segundo Selltiz (1974), é tornar o fenômeno em questão familiar ou conseguir uma nova compreensão deste. Além disso, utiliza-se esse tipo de estudo quando se quer apresentar características específicas de uma dada situação, um grupo ou um indivíduo específico. O estudo exploratório pode ainda, ter outras funções. O pesquisador pode querer aumentar o conhecimento sobre o fenômeno que deseja investigar de uma forma mais estruturada, futuramente, ou esclarecer conceitos, estabelecer prioridades, obter informações sobre possibilidades na vida real, apresentar problemas considerados urgentes para pessoas que trabalham em campos das ciências sociais. O estudo em questão enquadra-se nos primeiros aspectos mencionados, já que outras pesquisas realizadas não trouxeram a familiaridade do tema, tampouco características específicas desse grupo de indivíduos. Trata-se de um passo inicial a um processo contínuo de pesquisa.

O trabalho caracterizou-se como descritivo, buscando, desta maneira, identificar as variáveis que determinam os critérios de QVT. Aborda desde o aspecto da descrição, passando pelo registro, análise e interpretação de fenômenos atuais (Marconi \& Lakatos, 1982). Deste modo, pôde-se descrever quais são as percepções dos professores quanto aos fatores que estes consideraram importantes.

Para realizar o estudo foi escolhida, inicialmente, uma organização que se dedica ao ensino de idiomas, mais especificamente ao inglês. Porém, devido a algumas mudanças nas atribuições de responsabilidades das pessoas contatadas, foram fechadas as portas para a realização deste estudo. Com isso, tentou-se buscar outras organizações do mesmo setor, mas encontrou-se muita resistência quando eram mostradas as linhas gerais da pesquisa, ou seja, ao chegar a solicitação à coordenação, esta não permitia a realização do estudo, pois o mesmo 
focava os professores da instituição, fato este que tornava inviável a pesquisa aos olhos das instituições.

Diante deste quadro, optou-se por mudar o foco da pesquisa, deixando de lado a idéia de se investigar uma organização em particular, e abrindo a pesquisa para a categoria "professores de inglês", não importando a instituição na qual estivessem vinculados.

Toda pesquisa implica no levantamento de dados de variadas fontes, quaisquer que sejam os métodos ou técnicas empregadas. Marconi e Lakatos (2003, p. 174) definem que técnica "é um conjunto de preceitos ou processos de que se serve uma ciência ou arte; é a habilidade para usar esses preceitos ou normas, a parte prática. Toda ciência utiliza inúmeras técnicas na obtenção de seus propósitos." O estudo está focado na Observação Direta Extensiva, mais especificamente no Questionário.

O levantamento de dados foi realizado em duas etapas:

(1) Dados secundários: Revisão bibliográfica sobre os fatores críticos da G-QVT, ou seja, o conceito de QVT, produtividade, legitimidade, o perfil do gestor, práticas e valores e a nova competência. Ademais, pesquisou-se acerca dos cursos de idiomas no Brasil, bem como os profissionais atuantes desse segmento, incluindo artigos, teses e livros, além da própria vivência da autora e contatos informais com profissionais da área.

Foram consultadas pesquisas acadêmicas em QVT entre 2000 e 2005, disponibilizadas on-line (trabalho integral) nas Universidades cujos cursos de Administração, Psicologia e Engenharia de Produção obtiveram conceito 5, 6 ou 7 (Mestrado e Doutorado) na CAPES em 2004 (CAPES, 2005). A escolha destes cursos deveu-se ao fato de serem os que mais apresentam pesquisas no tema QVT. A escolha da conceituação CAPES deveu-se unicamente a uma 
questão de delimitação, visto que existem inúmeros trabalhos que tratam do tema e que poderiam ser consultados, porém, dada a questão do tempo, optou-se por não abarcar todas as fontes desejadas.

(2) Dados primários: realizou-se uma pesquisa quantitativa junto aos professores de inglês. Foi utilizada a pesquisa survey, que pode ser descrita como a obtenção de dados ou informações sobre características, ações ou opiniões de determinado grupo de pessoas, indicado como representante de uma população-alvo, por meio de um instrumento de pesquisa, um questionário (Tanur apud Freitas et al., 2000).

\subsection{Caracterização da Amostra}

A amostra do estudo constituiu-se de professores de inglês, atuantes, principalmente, em cursos livres. Caracteriza-se como uma amostra não-probabilística. Freitas et al. (2000) consideram que a amostra não-probabilística é obtida a partir de algum critério, e nem todos os elementos da população têm a mesma chance de serem selecionados, o que torna os resultados não generalizáveis, pois não garantem a representatividade da população (Martins, 2000). As técnicas de amostragem não-probabilística não fazem uso de formas aleatórias de seleção, podem não ser objeto de certos tipos de tratamento estatístico (Marconi \& Lakatos, 1982). Considera-se o tipo de amostra não-probabilística utilizado nesta pesquisa por conveniência.

\subsection{Elaboração do Instrumento de Coleta de Dados}

Tendo em vista a escolha do método e técnica utilizados, serão abordados alguns aspectos relacionados à utilização do questionário. O questionário é um instrumento de coleta de dados, constituído por uma série ordenada de perguntas, respondidas por escrito e sem a 
presença do entrevistador. Deve-se enviar uma nota explicando a natureza da pesquisa, sua importância e a necessidade de obter respostas, de modo que o respondente preencha e devolva o questionário dentro de um prazo razoável (Marconi \& Lakatos, 2003).

Pardinas (1969) define que é um sistema de perguntas cuja finalidade é obter dados para uma futura análise. Destaca que é fundamental que a construção do questionário siga um procedimento estrito, ou seja, deve ser elaborado considerando o objetivo do estudo, inicialmente definido.

Levantamentos iniciais foram realizados com os professores presentes em um Congresso ocorrido em Julho de 2004 na cidade de Cajamarca, no Peru (Kanikadan \& Limongi-França, 2004). O grupo foi composto por professores de inglês que atuam em instituições de nível fundamental, médio, superior e cursos livres. Estiveram presentes também alunos das instituições peruanas, totalizando 30 pessoas. Selltiz (1974) destaca que o estudo da experiência e conhecimento das pessoas são ótimas fontes para se observar efeitos de ações e decisões alternativas referentes a problemas de relações humanas. Acrescenta que a idéia do estudo da experiência é compreender, através das práticas atuais, informações provocantes e úteis, e para isso, as pessoas precisam ser escolhidas por causa da probabilidade de que ofereçam as contribuições procuradas. Vale observar que não existe regra para determinar o número de informantes que devem ser entrevistados em um estudo de experiência.

Foi proposto um exercício cruzando os Fatores Críticos de Sucesso para a GQVT e a abordagem BPSO-96. Para cada um dos fatores críticos, foi necessário descrever um aspecto 
biopsicossocial. As 30 pessoas participaram da atividade, onde foram divididas em 6 grupos (número de fatores críticos). Vide quadro 4.1.

Quadro 4.1- Definição do conceito de QVT sob os aspectos BPSO-96

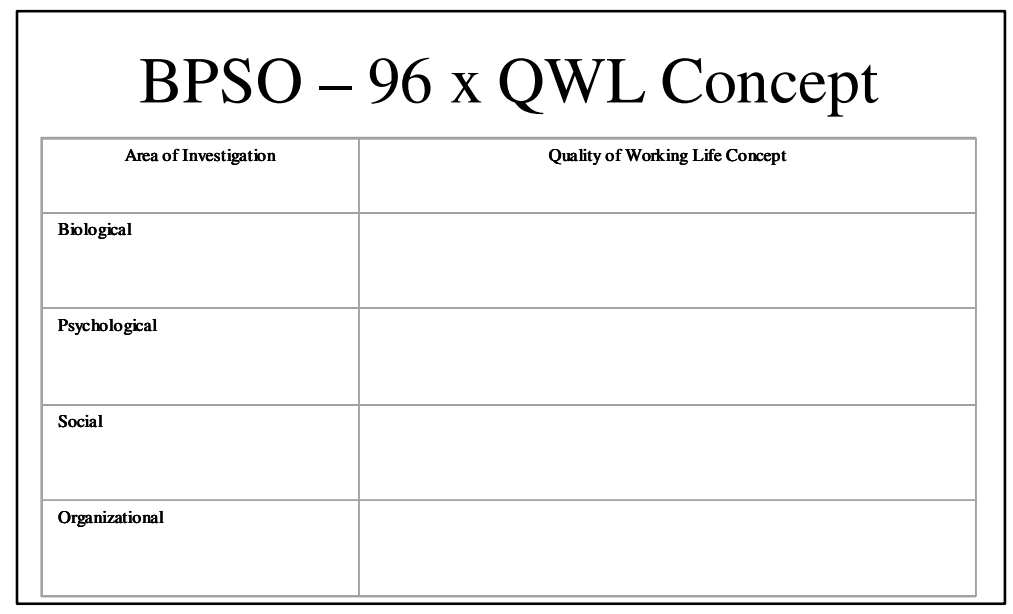

A partir da atividade proposta, e posterior apresentação dos grupos, gerou-se o quadro 4.2:

Quadro 4.2- Idéias geradas a partir do exercício proposto

\begin{tabular}{|c|c|c|c|c|c|}
\hline & & Bio & psychosocia & View (BPS & O-96) \\
\hline & & Biological & Psychological & Social & Organizational \\
\hline 옹 & QWL Concept & - working hours & $\begin{array}{l}\text { - Pressure } \\
\text { - Too much work } \\
\text { - Salary }\end{array}$ & \begin{tabular}{|l} 
- Lack of \\
interaction \\
- Cultural events
\end{tabular} & $\begin{array}{l}\text {-Many tasks at the same } \\
\text { time }\end{array}$ \\
\hline 它 & Productivity & $\begin{array}{l}\text { - no insurance } \\
\text { - low income } \\
\text { - low performance } \\
\text { - need of good health } \\
\text { condition }\end{array}$ & $\begin{array}{l}\text { - accept any job } \\
\text { - moral harassment } \\
\text { - director are not } \\
\text { prepared }\end{array}$ & $\begin{array}{l}\text { - they don't have } \\
\text { too much to offer } \\
\text { - lack of time }\end{array}$ & $\begin{array}{l}\text {-Style of leadership } \\
\text { - no id with the institution }\end{array}$ \\
\hline 는 & Legitimacy & $\begin{array}{l}\text {-No benefits (health } \\
\text { problems) }\end{array}$ & $\begin{array}{l}\text { - stress } \\
\text { - working pressure } \\
\text { - crazy }\end{array}$ & \begin{tabular}{|l|}
-No contract \\
- form study groups \\
- exchange \\
experiences
\end{tabular} & $\begin{array}{l}\text { - Can't join groups } \\
\text { thst defend their rights }\end{array}$ \\
\hline 岕 & Manager's Profile & $\begin{array}{l}\text { - Former teacher } \\
\text { - mental and physical } \\
\text { health } \\
\text { - good leader }\end{array}$ & $\begin{array}{l}\text { - honesty } \\
\text { - open-minded } \\
\text { - good relationship } \\
\text { - accept advices/listen }\end{array}$ & \begin{tabular}{|l|} 
- friendly \\
- nice \\
- socialize
\end{tabular} & $\begin{array}{l}\text { - understand teacher's } \\
\text { needs (study, } \\
\text { onvention) } \\
\text { - improve }\end{array}$ \\
\hline$\sum^{\frac{\pi}{0}}$ & Practices \& Values & - do their best & $\begin{array}{l}\text { - respect each one's } \\
\text { ideas } \\
\text { - practices \& values }\end{array}$ & $\begin{array}{l}\text { - goals \& objectives } \\
\text { - interact/degree }\end{array}$ & - establish goals \\
\hline § & New Competency & $\begin{array}{l}\text { - physical health } \\
\text { - good nutrition } \\
\text { - explore abilities }\end{array}$ & $\begin{array}{l}\text { - mental health } \\
\text { - prepared to } \\
\text { technology changes }\end{array}$ & $\begin{array}{l}\text {-Good relationship } \\
\text { with community }\end{array}$ & $\begin{array}{l}\text { - must be a teacher } \\
\text { - study Business } \\
\text { Administration }\end{array}$ \\
\hline
\end{tabular}

As respostas serviram de base para o estabelecimento das assertivas do questionário, caracterizadas como as variáveis da pesquisa. 
De acordo com Marconi \& Lakatos (2003), para se elaborar um questionário deve-se levar em conta os tipos, a ordem, o grupo de perguntas, a formulação das mesmas. O pesquisador deve conhecer bem o assunto de modo que organize em temas e a partir disso, extraia duas ou três perguntas. É necessário que se observe bem os objetivos geral e específico. Além disso, deve ser limitado em extensão e finalidade, de modo que demore em torno de 30 minutos para respondê-lo. As questões devem ser identificadas e codificadas visando facilitar a tabulação. É importante também considerar a estética e o aspecto material. Pardinas (1969) destaca a necessidade de se levar em consideração a estrutura intelectual do grupo que responderá a pesquisa.

Segundo Goode \& Hatt (1972), desenvolver um questionário é mover-se de dentro para fora. O pesquisador deve esboçar as implicações lógicas do seu problema e depois se apoiar na sua experiência e literatura para obter questões importantes referentes àquelas implicações.

Para Limongi-França (1996), os elementos ou valores característicos de um fato ou conceito a ser estudado são as variáveis, que dentro de um conjunto potencial amplo têm como base a expectativa de serem aspectos de impacto significativo para se manipular a situação proposta. São, portanto, quantidades ou condições medidas e controladas que traduzem uma propriedade ou característica observável de um sistema. O estabelecimento das variáveis, suportado pelos conceitos teóricos, permite que as perguntas do questionário sejam elaboradas. 
Para este estudo, foram criadas 45 assertivas e 15 questões de qualificação. Foi utilizada uma escala de 6 pontos, além da opção NA-não se aplica. Segundo Mattar (1996), as escalas de avaliação são utilizadas para medir variáveis que envolvem escalas do tipo ordinais, ou seja, solicita-se às pessoas que respondam às suas percepções em relação ao que foi perguntado.

A escala utilizada para as questões de 1 a 45 pode ser caracterizada como um escala de avaliação verbal, oferece opção de resposta às pessoas desde o extremo mais favorável até o extremo mais desfavorável, identificado através de expressões verbais, neste caso: Concordo Totalmente (extremo mais favorável) ao Discordo Totalmente (extremo mais desfavorável).

Não existe um consenso sobre a melhor escala a ser utilizada, se número ímpar ou par de categorias, porém, para este estudo foi necessária a existência de uma categoria NA (não se aplica), pois quando os questionários foram enviados aos professores de inglês, o foco eram os professores que lecionam em cursos livres.

Para as questões de qualificação foram utilizadas escalas nominais e escalas de razão ou intervalares. As escalas nominais são aquelas que nomeiam, identificam e (ou) categorizam dados sobre pessoas, objetos ou fatos. Neste estudo utilizou-se tal escala para as questões: 48, 50, 52, 53, 54, 55 e 58. Para as questões 46, 47, 49 e 51, foram utilizadas as escalas de razão ou intervalares cuja definição é apresentar intervalos de medição (Martins, 2001).

Sauaia (1995) explica que as variáveis dos tipos intervalares ou razão demonstram maior aplicabilidade estatística, como o cálculo da moda, mediana, média e desvio padrão. 
Parasuraman apud Sauaia (1995) defende que uma escala de 6 pontos pode ter propriedades intervalares, isto é, os respondentes tendem a tratar as diferenças entre categorias adjacentes como iguais, especialmente quando as categorias estão separadas por distâncias iguais. Por isso, as escalas ordinais podem ser submetidas ao mesmo tratamento das escalas intervalares, permitindo o cálculo da média e do desvio-padrão.

Considerando o Conceito de QVT, foram definidas as seguintes assertivas:

\begin{tabular}{|l|l|}
\hline B & 1- A quantidade de horas trabalhadas prejudica meu estado geral de saúde. \\
\hline B & 2- Os espaços em que trabalho estão adaptados à condição física dos professores. \\
\hline P & 3- As horas trabalhadas têm afetado minhas atividades dentro e fora da aula. \\
\hline P & 4- O salário recebido no final do mês é algo que me preocupa. \\
\hline S & 5- Sinto uma falta de interação com os superiores imediatos. \\
\hline S & 6- Seria interessante termos mais eventos culturais envolvendo os professores. \\
\hline O & $\begin{array}{l}\text { 7- Considero a flexibilidade de horário como algo positivo, pois posso trabalhar em horários que me permitam realizar } \\
\text { outras atividades paralelamente. }\end{array}$ \\
\hline O & 8- Realizo muitas atividades ao mesmo tempo. \\
\hline B-biológico; P-psicológico; S- social; O-organizacional
\end{tabular}

As variáveis geradas a partir do entendimento da visão BPSO-96 possibilitaram definir as assertivas abaixo sobre a questão de Produtividade:

\begin{tabular}{|l|l|}
\hline B & 9- Com a segurança de um convênio médico, posso dar melhores aulas. \\
\hline B & 10- Se eu tivesse um salário melhor, daria melhores aulas. \\
\hline B & 11- A instituição incentiva à prática de esportes. \\
\hline B & 12- Costumo me locomover (fisicamente) de uma instituição a outra, várias vezes ao dia. \\
\hline P & 13- Tenho facilidade de encontrar trabalho nesta área. \\
\hline P & 14- O apoio fornecido pela coordenação é fundamental para a minha boa performance em sala de aula. \\
\hline P & 15- Durante um ano, fico pelo menos, 2 meses sem dar aulas devido às férias dos alunos. \\
\hline S & 16- A coordenação tem pouco tempo para dialogar com os professores, afetando os resultados em sala de aula. \\
\hline O & 17- Tenho a oportunidade de participar de decisões de planejamento. \\
\hline O & 18- Não consigo me identificar com a organização. \\
\hline B-biológico; P-psicológico; S- social; O-organizacional
\end{tabular}


Para o fator crítico Legitimidade gerou-se o seguinte:

\begin{tabular}{|l|l|}
\hline B & $\begin{array}{l}\text { 19- Continuo na organização porque ela fornece alguns benefícios, como vale refeição, cesta básica, ou similar, } \\
\text { previdência privada. }\end{array}$ \\
\hline B & 20- O convênio médico oferecido é um diferencial no mercado. \\
\hline P & 21- Minha família se orgulha de mim porque sou um professor desta instituição. \\
\hline P & 22- Minha família se orgulha de mim porque sou um professor de inglês. \\
\hline P & 23- Não me orgulho em trabalhar nesta instituição. \\
\hline S & 24- Existe um grande empenho dos professores em ajudar outros professores. \\
\hline S & 25- Temos a oportunidade de participar de congressos, nacionais e/ou internacionais. \\
\hline O & 26- A oportunidade de carreira oferecida pela organização é muito atraente. \\
\hline O & 27- A avaliação de desempenho realizada pela coordenação gera resultados positivos. \\
\hline
\end{tabular}

B-biológico; P-psicológico; S- social; O-organizacional

Com a definição do Perfil do Gestor, pôde-se extrair as assertivas a seguir:

\begin{tabular}{|l|l|}
\hline B & 28- O pessoal da coordenação entende que uma boa saúde é fundamental para o bom desempenho em sala de aula. \\
\hline P & 29- O pessoal da coordenação sabe ouvir sempre as sugestões dos professores. \\
\hline S & 30- Tenho um relacionamento satisfatório com minha coordenação. \\
\hline S & 31- Recebo apoio para realizar trabalhos junto à comunidade. \\
\hline O & 32- A organização fornece financiamento de cursos externos, que complementam a formação do professor. \\
\hline O & 33- Tenho a oportunidade de realizar outros cursos de idiomas. \\
\hline
\end{tabular}

B-biológico; P-psicológico; S- social; O-organizacional

Visando identificar as Práticas e Valores que a empresa realiza, foram definidas as seguintes assertivas:

\begin{tabular}{|l|l|}
\hline B & 34- Existem campanhas visando melhorar os maus hábitos dos funcionários (fumo, álcool, sedentarismo). \\
\hline P & 35- Há o respeito às idéias dadas pelos funcionários. \\
\hline P & 36- Meus superiores e meus pares criam um ambiente de harmonia e respeito. \\
\hline S & 37- A empresa participa de programas voltados para a cidadania. \\
\hline O & 38- Percebo que os Instrumentos utilizados para recrutamento e seleção dos professores são adequados. \\
\hline O & 39- A instituição nos prepara tecnicamente para lidar com a evolução tecnológica. \\
\hline
\end{tabular}

B-biológico; P-psicológico; S- social; O-organizacional 
Para desvendar se a instituição possuía espaço para o desenvolvimento de uma Nova Competência, ou até mesmo se já possui, destacam-se as assertivas:

\begin{tabular}{|l|l|}
\hline B & 40- Acredito que é fundamental para os funcionários desenvolverem hábitos de vida saudáveis. \\
\hline P & 41- Meu coordenador sempre me ajuda quando tenho problemas que afetam meu estado emocional. \\
\hline S & 42- O professor deve apresentar conhecimentos sócio-culturais e competência intercultural. \\
\hline O & $\begin{array}{l}\text { 43- É fundamental para o professor de inglês conhecer teorias sobre aquisição da linguagem e da língua estrangeira, } \\
\text { fonética/fonologia, correntes da lingüística, semiótica e semiologia, análise do discurso, etnografia da comunicação. }\end{array}$ \\
\hline O & $\begin{array}{l}\text { 44- O professor deve possuir conhecimento de métodos e metodologias para o ensino da língua estrangeira, didática } \\
\text { ao conceber atividades pedagógicas; compreensão do público-alvo, de suas necessidades e de suas estratégias de } \\
\text { aprendizado, boa dição. }\end{array}$ \\
\hline O & $\begin{array}{l}\text { 45- O professor de inglês deve apresentar domínio da língua materna e da língua estrangeira do ponto de vista } \\
\text { gramatical, semântico e discursivo. }\end{array}$ \\
\hline B-biológico; P-psicológico; S- social; O-organizacional
\end{tabular}

Vale lembrar que a divisão dos aspectos biopsicossociais é algo puramente didático, fato este que pode ser comprovado ao observar o quadro 4.2 das variáveis e o produto obtido com as assertivas.

Marconi \& Lakatos (2003) classificam as perguntas em três categorias: abertas, as que permitem ao informante responder livremente, de acordo com sua opinião; fechadas, são aquelas que só oferecem duas opções, sim ou não; e, múltipla escolha, que apresentam uma série de possíveis respostas, abrangendo várias facetas do mesmo assunto. As perguntas de múltipla escolha podem ser com mostruário (o informante assinala uma ou várias delas) e perguntas de estimação ou avaliação (o informante emite um julgamento através de uma escala com vários graus de intensidade para um mesmo item). Existem também as perguntas de fato que dizem respeito a questões concretas, tangíveis, fáceis de precisar, como idade, sexo, profissão etc.

Pardinas (1969) destaca a importância de se observar o conteúdo das perguntas, ou seja, se as mesmas são realmente necessárias e estão descritas de forma que não induza o respondente a escrever uma determinada resposta. Quanto ao vocabulário, é necessário atentar 
para o público que irá responder ao questionário, de modo que as palavras sejam compreendidas pelos mesmos. A importância de se estudar a seqüência das perguntas está no fato de se evitar a contaminação, pois dependendo da ordem das perguntas, estas podem fazer com que o respondente seja influenciado pelas outras perguntas que já respondeu. Marconi \& Lakatos (2003) denominam bateria, a série de perguntas cuja finalidade é aprofundar algum ponto da investigação, mas desde que a mesma não incorra no perigo da contaminação.

Goode \& Hatt (1972) argumentam que os questionários geralmente começam com questões inofensivas, deixando as mais complexas para o final, em especial aquelas que são de cunho pessoal (Marconi \& Lakatos, 2003). É importante que o instrumento seja iniciado por um item bastante atraente, sem ser controverso, para que o respondente não se recuse a responder a pesquisa. $\mathrm{O}$ começo deve provocar o interesse e envolver o informante.

Algumas questões de qualificação foram definidas de forma diferenciada, ou seja, foram adotados alguns critérios específicos que serão expostos a seguir:

- Idade: inicialmente a coleta de dados foi realizada através de uma pergunta aberta. Porém, para critérios de tabulação foram agrupadas em faixas, tendo como referência os estágios da vida e carreira definidos por Super \& Bohn (1972):

- Estágio de Crescimento: do nascimento aos 14 anos;

- Estágio de Exploração (auto-análise, representação de papéis e exploração ocupacional):

○ Tentativa: dos 15 aos 17 anos;

○ Transição: dos 18 aos 21 anos;

- Experiência: dos 22 aos 24 anos. 
- Estágio de Estabelecimento (concentração de esforços para permanecer em uma área tida como a desejada):

- Experiência: dos 25 aos 30 anos;

○ Estabilização: dos 31 aos 44 anos.

- Estágio de Permanência: dos 45 aos 64 anos;

- Estágio de declínio: a partir dos 65 anos.

- Faixa salarial: foi definida tendo em vista a experiência da autora em algumas instituições de ensino de inglês em 2002, considerando possibilidades de ganhos máximos, ou seja, as instituições remuneram, em média, de $\mathrm{R} \$ 10,00$ a $\mathrm{R} \$ 15,00$ a hora/aula. Fazendo um cálculo de 40 horas de trabalho na semana, o ganho máximo de um professor nessas condições é de R\$ $1.600,00$ a $\mathrm{R} \$ 2.400,00$ por mês.

- Cursos e graus em que leciona: esta pergunta teve o objetivo de filtrar os respondentes da pesquisa, ou seja, como não houve uma maneira mais fácil de se conseguir professores de inglês de cursos livres para responder à pesquisa, optou-se por enviar a todos os profissionais que afirmassem que são professores de inglês, não importando a natureza do curso nem o grau em que lecionam.

\subsection{Pré-teste}

Marconi \& Lakatos (1982) destacam a importância de se realizar um teste com o instrumento de pesquisa, antes de ser aplicado definitivamente, a fim de evitar que a pesquisa chegue a um resultado falso. Acrescentam que nem sempre é possível prever todas as dificuldades e problemas decorrentes de uma pesquisa que envolva a coleta de dados, pois 
podem existir perguntas subjetivas, mal formuladas, ambíguas, de linguagem inacessível, entre outras. Por isso, é suficiente que tal teste seja realizado com algo em torno de 5 a $10 \%$ do tamanho da amostra, considerando a experiência do investigador, o qual deve ser capaz de determinar a validade do método e dos procedimentos utilizados.

O questionário foi enviado a cinco pessoas atuantes no curso de Mestrado da FEA/USP, como forma de se obter as críticas e sugestões de pesquisadores. Alguns aspectos como lay out e linguagem foram modificados.

Em um segundo momento, o questionário foi pré-testado com cinco pessoas atuantes na área em questão, sendo a sua aplicação feita pela pesquisadora, tendo em vista o aperfeiçoamento do instrumento de pesquisa, de modo que o mesmo fosse eficiente na busca do objetivo em questão. Algumas alterações foram feitas, em especial no que diz respeito à ordem das perguntas, que facilitou muito a tabulação.

Apesar de o pré-teste ter sido realizado, cabe ressaltar que, a escala de mensuração utilizada nas questões 1 a 45, a existência da opção NA (não se aplica), prejudicou um pouco o estudo, pois os professores, ao responderem NA, geraram uma dúvida na tabulação, ou seja, acredita-se que muitos respondentes informaram NA para as situações em que tal variável não existia. A idéia não era essa, o NA - não se aplica, deveria ser utilizado para situações como: professores de inglês particulares, que por exemplo, não possuem superiores; professores de outros cursos cujas respostas, se fossem dadas, não teriam sentido em existir. Optou-se por excluir os casos em que tal fenômeno se sucedesse, sendo denominados de missing values no programa SPSS. 


\subsection{Coleta de Dados}

A coleta de dados foi realizada nos meses de abril, maio e junho de 2005 (04 de abril a 30 de junho), caracterizando-se como um corte transversal, ou seja, ocorreu em um só momento, possibilitando a análise e descrição das variáveis no período. O preenchimento deuse de três maneiras: através do questionário eletrônico disponibilizado na Internet; envio de questionário por e-mail e visitas pessoais às escolas, onde os professores preencheram o instrumento de coleta em papel impresso. Os contatos foram obtidos através de associações de professores de inglês e editoras de livros da área, além de consultas aos sites das universidades que possuem cursos de Letras e escolas de inglês que disponibilizam e-mails para contato. Foram obtidos 125 questionários. Deste total, foram considerados 91 questionários, pois a questão 55 teve a função de filtro, devido às mudanças que foram efetuadas na escolha da empresa e alvo da pesquisa. O foco do trabalho esteve nos professores que se dedicam aos cursos livres. Imaginou-se que considerá-los todos em uma única amostra traria muitos vieses à pesquisa.

\subsection{Formas de análise dos resultados}

Por se tratar de uma amostra não-probabilística, não se têm conhecimento dos parâmetros da população, portanto as técnicas de análise são as não-paramétricas. Os parâmetros de uma população compreendem dados reais como tipo de distribuição, média, desvio-padrão. As variáveis foram medidas em escalas ordinais, nominais e intervalares ou razão. Foram realizadas as análises univariada (analisar uma única variável por vez) e bivariada (analisar as relações entre duas variáveis por vez). Não foi possível realizar a análise multivariada, pois: 
1) a Análise de Cluster é uma análise de proximidade geométrica entre objetos estudados e deve ser usada quando se quer identificar grupos de características semelhantes, ou seja, categorizar as observações levando em conta todas as medidas originais (Pereira, 2004). Isto não ocorreu neste estudo, dada a homogeneidade das respostas;

2) a Análise de Correspondência é aplicada quando se pretende estudar a relação entre duas variáveis nominais (Pestana \& Gageiro, 2003). Deriva plano de projeção através de análise de componentes principais (Pereira, 2004). Neste estudo, as variáveis analisadas quanto à associação não são nominais, e além disso, a análise de correspondência, ao ser realizada no SPSS recorre ao teste qui-quadrado para testar a relação de dependência entre as variáveis, teste este que não pôde ser realizado devido ao estudo apresentar variáveis com observações inferior a 5 nas categorias.

3) a Análise Fatorial é a análise de componentes principais, que procura explicar a correlação entre as variáveis observáveis, simplificando os dados através da redução do número de variáveis necessárias para os descrever (Pestana \& Gageiro, 2003). A amostra deve ser suficientemente grande, conforme sugerem Hair et al. (1998), ou seja, apresentar mais de 100 observações, ou o mínimo de cinco vezes o número de variáveis a serem analisadas, fato este que já impediu a realização deste tipo de análise no presente estudo.

O método de análise utilizado foi o método descritivo: proporciona informações sintetizadas dos dados apresentados na amostra, que podem ser medidos através das: medidas de posição, medidas de dispersão e medidas de associação.

As medidas de posição podem ser: 
Moda: realização mais freqüente do conjunto de valores observados (Bussab \& Morettin, 1987);

Mediana: realização que ocupa a posição central da série de observações quando estas estão ordenadas segundo suas grandezas, crescente ou decrescente (Bussab \& Morettin, 1987);

Média: é a soma das observações dividida pelo número delas (Bussab \& Morettin, 1987);

$>$ Quartis: dividem o conjunto de dados em quatro partes iguais, ou seja, o $1^{\circ}$. quartil engloba $25 \%$ dos elementos, o $2^{\circ}$. quartil (mediana), $50 \%$ dos elementos e o $3^{\circ}$. quartil, 75\% dos elementos (Martins, 2001).

As medidas de dispersão utilizadas nesse estudo são definidas como (Martins, 2001):

$>$ Distribuição de freqüência absoluta e relativa: quantidade de elementos que pertencem a uma classe;

Amplitude: é a medida de dispersão dada pela diferença entre o maior e menor valor da série;

Desvio-padrão: medir a dispersão de uma variável.

As medidas de associação utilizadas nesse estudo foram definidas como: 
Coeficiente de Correlação de Spearman: verificar a dependência entre variáveis ordinais. O coeficiente de Spearman pode variar de $-1,00$ a $+1,00$, significando que, quando estiver mais próximo desses extremos, maior será a associação linear entre as variáveis. $\mathrm{O}$ sinal negativo significa que as variáveis variam em sentido contrário, ou seja, quando uma se eleva, a outra diminui. O sinal positivo significa que variam no mesmo sentido (Pestana \& Gageiro, 2003). O nível descritivo informa a significância estatística do coeficiente de Spearman; assim, para valores menores que $10 \%$ ou $5 \%$, considera-se que as variáveis tenham alguma associação.

Teste de Qui-Quadrado: de acordo com Magalhães \& Lima (2000), pode ser utilizado para o teste de Independência ou associação. De acordo com Martins (2001), ao estudar a associação ou dependência entre duas variáveis, observa-se a representação das frequiências dada por uma tabela de dupla entrada, ou a tabela de contingência. Porém, para este estudo, observou-se que o qui-quadrado não pôde ser calculado quando uma tabela de $\mathrm{RxC}$, onde o $\mathrm{R}$ representa uma variável e sua categoria e o C a outra variável e sua categoria, apresentar células com frequiência inferior a 5. Quando isto ocorre, utilizam-se outros formas de medir a associação, sendo utilizado, neste estudo, o coeficiente de correlação de Spearman.

A análise foi dividida em 2 (duas) partes: a análise dos resultados que caracterizam a amostra e a análise dos resultados que representam as respostas ao objetivo da pesquisa. $\mathrm{O}$ quadro 4.3 resume os objetivos e as técnicas de análise utilizadas: 
Quadro 4.3 - Resumo dos objetivos e técnicas de análise

\begin{tabular}{|c|c|c|c|c|}
\hline Objetivos & Variáveis & Tipo de variável & Escala da variável & Medição da variável \\
\hline $\begin{array}{l}\text { Geral: Identificar as percepções dos professores } \\
\text { de inglês sobre a Qualidade de Vida no Trabalho. }\end{array}$ & Questões 1 a 45 & Nominal & Escala ordinal & $\begin{array}{l}\text { Média } \\
\text { Desvio-padrão } \\
\text { Distribuição de freqüência acumulada (absoluta e } \\
\text { relativa) } \\
\text { Mediana } \\
\text { Quartis } \\
\text { Ordenamento } \\
\text { Amplitude }\end{array}$ \\
\hline Identificar se os indicadores de QVT guardam & Número de dependentes & Ordinal & Escala ordinal & Moda \\
\hline alguma relação com a condição sócio-econômica: & Estado civil & Nominal & Escala nominal & Distribuição de freqüência absoluta e relativa \\
\hline - Questão 1 & Faixa salarial & Ordinal & Escala intervalar & Coef. De correlação de Spearman e Teste F \\
\hline • Questão 3 & Tempo de profissão & Nominal & Escala nominal & \\
\hline • Questão 5 & Idade & Ordinal & Escala intervalar & \\
\hline - Questão 10 & Regime de trabalho & Ordinal & Escala intervalar & \\
\hline - Questão 12 & Escolaridade & Nominal & Escala nominal & \\
\hline - Questão 15 & Horas Trabalhadas & Valor calculado & Valor calculado & \\
\hline - Questão 20 & Sexo & Nominal & Escala nominal & \\
\hline $\begin{array}{l}\text { - Questão } 25 \\
\text { - Questão } 31 \\
\text { - Questão } 33 \\
\text { - Questão } 37 \\
\text { - Questão } 39 \\
\end{array}$ & Onde aprendeu o idioma & Nominal & Escala nominal & \\
\hline $\begin{array}{l}\text { Testar se os cursos livres empregam pessoas que } \\
\text { estudam no exterior com maior freqüência que } \\
\text { pessoas que estudaram no Brasil. }\end{array}$ & & Nominal & Escala nominal & $\begin{array}{l}\text { Moda } \\
\text { Distribuição de freqüência absoluta e relativa }\end{array}$ \\
\hline $\begin{array}{l}\text { Questão-filtro, pois foram considerados apenas os } \\
\text { questionários que informaram } 50 \% \text { ou mais de } \\
\text { tempo dedicado aos Cursos Livres, foco do } \\
\text { trabalho. }\end{array}$ & Tempo de profissão $\mathrm{X}$ renda & \multicolumn{2}{|c|}{$\begin{array}{l}\text { Duas variáveis intervalares } \\
\text { Testar que o tempo de profissão e a renda } \\
\text { são variáveis independentes. }\end{array}$} & Coef. De correlação de Spearman \\
\hline Relacionar tempo de profissão e renda. & $\begin{array}{l}\text { Faixa salarial } X \text { quantidade de horas } \\
\text { trabalhadas }\end{array}$ & \multicolumn{2}{|c|}{$\begin{array}{l}\text { Uma variável intervalar e uma variável } \\
\text { ordinal }\end{array}$} & Coef. De correlação de Spearman \\
\hline $\begin{array}{l}\text { Relacionar faixa salarial e quantidade de horas } \\
\text { trabalhadas. }\end{array}$ & Escolaridade X Faixa salarial & \multicolumn{2}{|c|}{$\begin{array}{l}\text { Uma variável intervalar e uma variável } \\
\text { ordinal }\end{array}$} & Coef. De correlação de Spearman \\
\hline Relacionar escolaridade e faixa salarial. & Outra ocupação além de professor & Nominal & Escala nominal & Coef. De correlação de Spearman \\
\hline Relacionar outra ocupação e faixa salarial & Outra ocupação X Faixa Salarial & \multirow{5}{*}{\multicolumn{2}{|c|}{ Escala Ordinal }} & Coef. De correlação de Spearman \\
\hline Identificar os aspectos Biológicos & $\begin{array}{l}\text { Questões } 1,2,9,10,11,12,19,20,28,34 \text { e } \\
40\end{array}$ & & & \multirow[t]{4}{*}{$\begin{array}{l}\text { Média } \\
\text { Desvio-padrão }\end{array}$} \\
\hline Identificar os aspectos Psicológicos & $\begin{array}{l}\text { Questões } \\
3,4,13,14,15,21,22,23,29,35,36,41\end{array}$ & & & \\
\hline Identificar os aspectos Sociais & Questões $5,6,16,24,25,30,31,37,42$ & & & \\
\hline Identificar os aspectos Organizacionais & $\begin{array}{l}\text { Questões } \\
7,8,17,18,26,27,32,33,38,39,43,44,45\end{array}$ & & & \\
\hline
\end{tabular}


Buscou-se estudar as percepções de QVT, referindo-se a resultados positivos e negativos encontrados nas situações do estudo, ou seja, para cada fator crítico citado, foi analisado o nível de concordância dos respondentes, e quando este foi percebido como positivamente alto, verificou-se uma percepção favorável quanto à QVT. A análise foi feita através das medidas de posição e medidas de dispersão, ou seja, as variáveis que se referiam a um determinado fator crítico (presente no modelo de competências) foram agrupadas, obtevese a média e o desvio-padrão, e a seguir, realizou-se uma análise por blocos de perguntas, permitindo-se assim, entender o fator crítico de forma consolidada.

Foi realizada uma outra análise tendo como referência o modelo BPSO-96, utilizandose também das medidas de posição e dispersão, ou seja, as variáveis que se referiam a cada aspecto, foram agrupadas e tratadas da mesma forma.

A tabulação foi feita utilizando-se o pacote estatístico SPSS, Statistical Package for Social Sciences, gerando tabelas e gráficos. 
Capítulo 5 - Resultados

Neste capítulo foram apresentados e analisados os resultados encontrados de acordo com o que foi exposto em Métodos e Recursos e na Fundamentação Teórica. Foram apresentados inicialmente, os resultados que caracterizam a amostra. A seguir, os resultados que deram as respostas ao objetivo da pesquisa.

Caracterização da Amostra:

A amostra concentra sua idade na faixa dos 25 aos 44 anos, representando $56 \%$ do total (Gráfico 5.1). De acordo com Super \& Bohn (1972), representa o estágio da estabilização na vida das pessoas.

Gráfico 5.1 - Classificação por Faixa etária

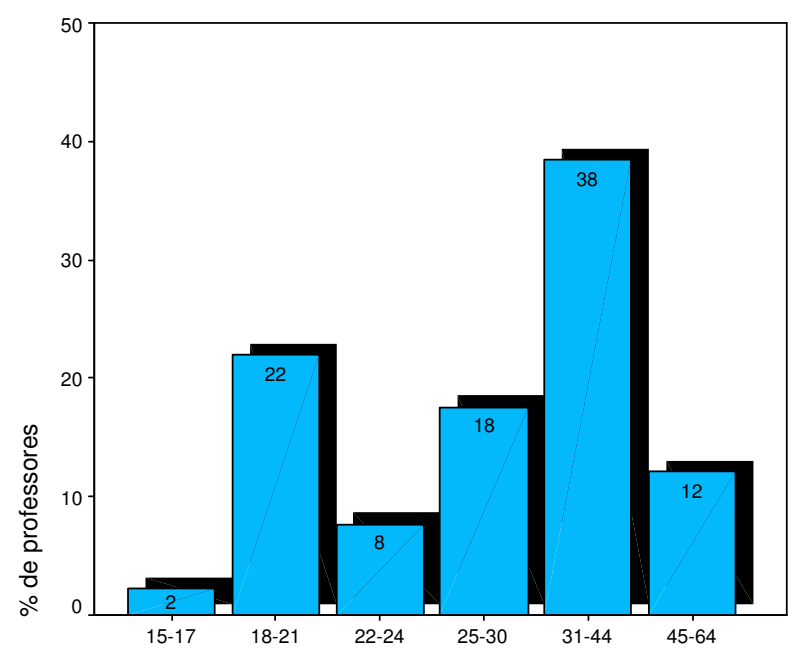


Quanto ao sexo, a amostra representa-se 74,7\% feminina, e 25,3\%, masculina (Gráfico $5.2)$.

Gráfico 5.2 - Classificação por Sexo

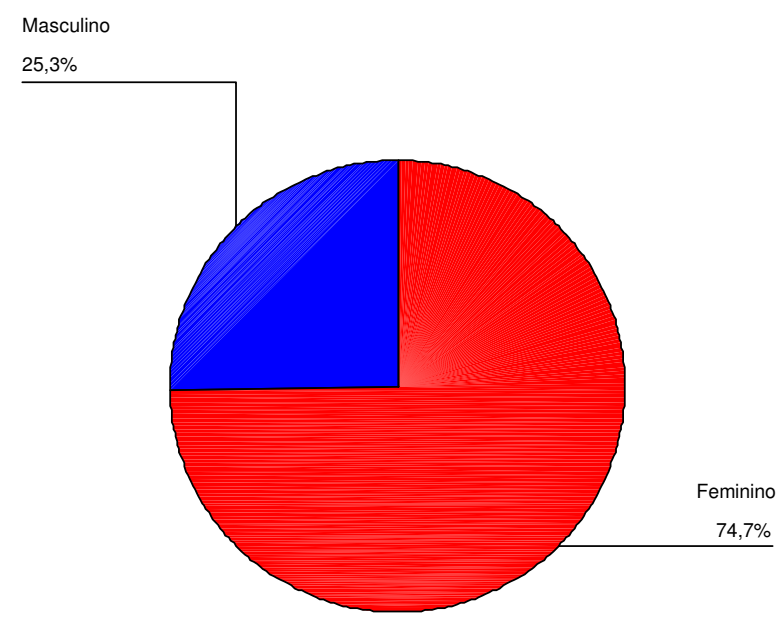

A amostra do estudo apresenta $32 \%$ de pessoas com superior incompleto, cabendo destacar que ainda estão cursando a graduação. É interessante observar que, embora os alunos não tenham a formação completa, muitos deles já atuam como professores de inglês. Logo em seguida, encontra-se na amostra, $29 \%$ dos profissionais com superior completo e $18 \%$ com pós-graduação (Gráfico 5.3).

Gráfico 5.3 - Classificação por Escolaridade

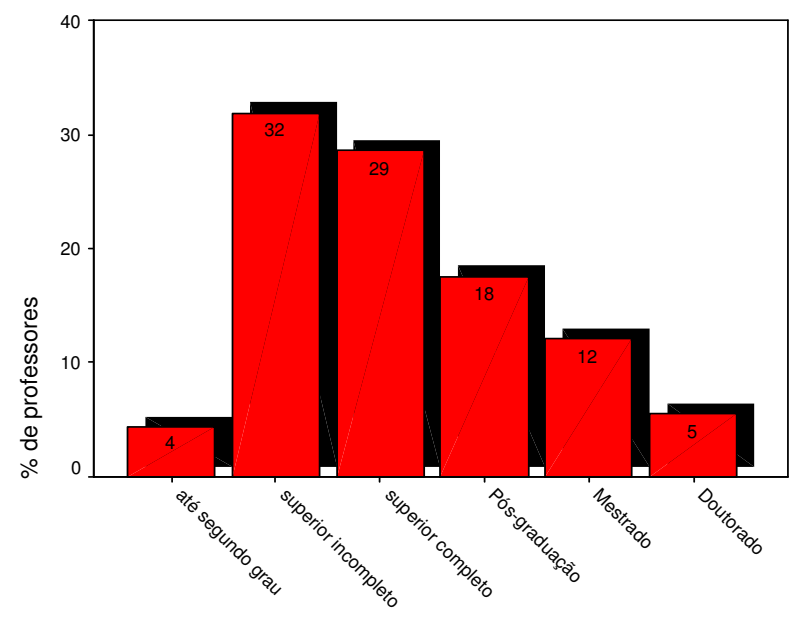


Esses $29 \%$ de respondentes que informaram possuir curso superior completo, tiveram suas formações nas áreas relacionadas a seguir (Quadro 5.1):

Quadro 5.1 - Classificação por formação acadêmica: graduação

\begin{tabular}{|l|l|}
\hline \multicolumn{1}{|c|}{ Nome do Curso } & \multicolumn{1}{|c|}{$\begin{array}{c}\text { Quantidade de } \\
\text { Respondentes }\end{array}$} \\
\hline Letras & 15 \\
\hline Direito & 2 \\
\hline Análise do discurso e ensino de língua estrangeiro & 1 \\
\hline Artes Cênicas & 1 \\
\hline Economia & 1 \\
\hline Engenharia Mecânica & 1 \\
\hline Jornalismo & 1 \\
\hline Língua e Literatura Inglesa - PUC & 1 \\
\hline Pedagogia & 1 \\
\hline Secretariado Bilíngüe - executivo & 1 \\
\hline Tradução & 1 \\
\hline Total & $\mathbf{2 6}$ \\
\hline
\end{tabular}

Os solteiros representam 57,1\% da amostra, seguidos dos 35,2\% de casados (Gráfico $5.4)$.

Gráfico 5.4 - Classificação por Estado Civil

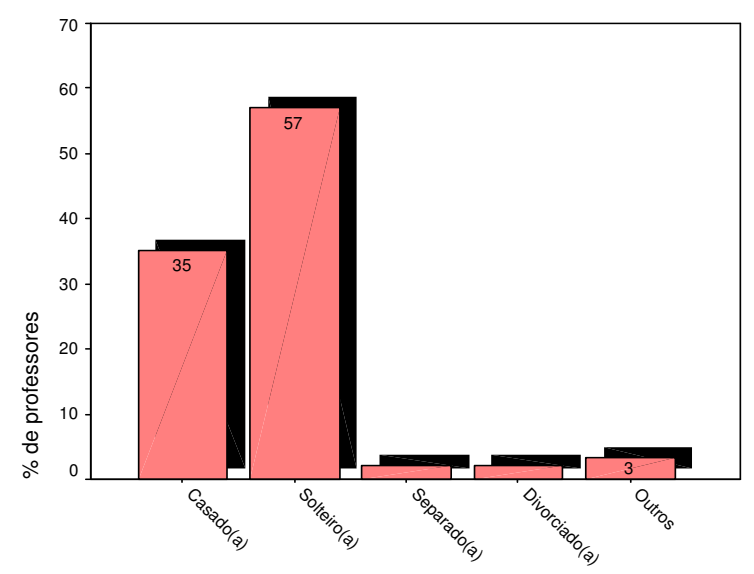


Tabela 5.1 - Classificação por Estado Civil: distribuição de freqüência

\begin{tabular}{|l|r|r|r|}
\hline & Frequência & Percentual & $\begin{array}{r}\text { Percentual } \\
\text { acumulado }\end{array}$ \\
\hline Casado(a) & 32 & 35,2 & 35,2 \\
Solteiro(a) & 52 & 57,1 & 92,3 \\
Separado(a) & 2 & 2,2 & 94,5 \\
Divorciado(a) & 2 & 2,2 & 96,7 \\
Outros & 3 & 3,3 & 100,0 \\
Total & 91 & 100,0 & \\
\hline
\end{tabular}

Grande parte de nossos respondentes ganha menos de $\mathrm{R} \$ 1.000,00$, representando 42,9\% do total. Percebe-se uma grande variação na composição salarial dos respondentes, pois há um equilíbrio nas faixas salariais (Gráfico 5.5 e Tabela 5.2), ou seja, 13,2\% ganha até $\mathrm{R} \$ 1.500,00,15,4 \%$ ganha até $\mathrm{R} \$ 2.000,00,14,3 \%$ ganha até $\mathrm{R} \$ 2.500,00$ e 9,9\% ganha acima de $\mathrm{R} \$ 3.000,00$, em contraposição aos $42,9 \%$ observados.

Gráfico 5.5 - Classificação por Faixa salarial

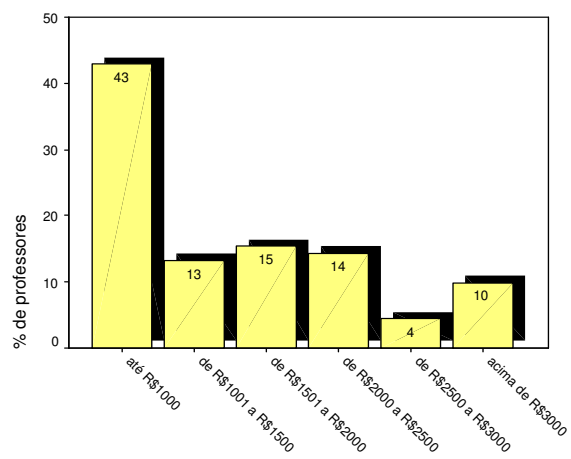

Tabela 5.2 - Classificação por faixa salarial: distribuição de frequiência

\begin{tabular}{|l|r|r|r|}
\hline & Frequêencia & Percentual & $\begin{array}{r}\text { Percentual } \\
\text { Acumulado }\end{array}$ \\
\hline até $\mathrm{R} \$ 1000$ & 39 & 42,9 & 42,9 \\
de $\mathrm{R} \$ 1001$ a $\mathrm{R} \$ 1500$ & 12 & 13,2 & 56,0 \\
de $\mathrm{R} \$ 1501$ a $\mathrm{R} \$ 2000$ & 14 & 15,4 & 71,4 \\
de $\mathrm{R} \$ 2001$ a $\mathrm{R} \$ 2500$ & 13 & 14,3 & 85,7 \\
de $\mathrm{R} \$ 2501$ a $\mathrm{R} \$ 3000$ & 4 & 4,4 & 90,1 \\
acima de $\mathrm{R} \$ 3000$ & 9 & 9,9 & 100,0 \\
Total & 91 & 100,0 & \\
\hline
\end{tabular}


Os respondentes da pesquisa, em sua maioria, não possuem dependentes, representando $72,5 \%$ do total (Gráfico 5.6).

Gráfico 5.6 - Classificação por Número de dependentes

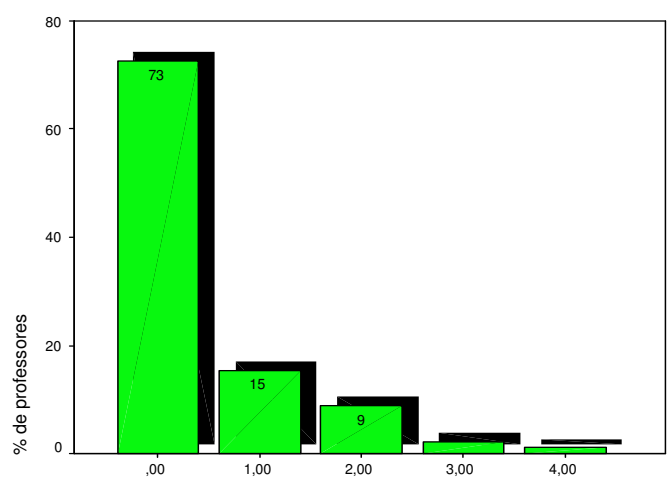

Tabela 5.3 - Classificação por número de dependentes: distribuição de freqüência

\begin{tabular}{|l|r|r|r|}
\hline & Freqüência & Percentual & $\begin{array}{r}\text { Percentual } \\
\text { Acumulado }\end{array}$ \\
\hline, 00 & 66 & 72,5 & 72,5 \\
1,00 & 14 & 15,4 & 87,9 \\
2,00 & 8 & 8,8 & 96,7 \\
3,00 & 2 & 2,2 & 98,9 \\
4,00 & 1 & 1,1 & 100,0 \\
Total & 91 & 100,0 & \\
\hline
\end{tabular}

Foi perguntado aos respondentes da pesquisa onde aprenderam o idioma inglês. Observa-se no gráfico 5.7 que 69,2\% aprenderam a língua inglesa no Brasil, enquanto que apenas $8,8 \%$ afirmaram tê-la aprendido no exterior. Considerando o aprendizado em ambos (Brasil e o exterior), 18,7\% afirmaram ter ido ao exterior aprender o idioma, além dos conhecimentos adquiridos no próprio país. Cabe destacar que, dos 63 respondentes que afirmaram ter aprendido o idioma no Brasil, 58 estudaram nos cursos livres existentes no Brasil. Com esse resultado vê-se a legitimidade que essas instituições representam na educação do país, ou seja, elas vêm formando os próprios professores de inglês. 
Gráfico 5.7 - Classificação por Local de aprendizado do idioma

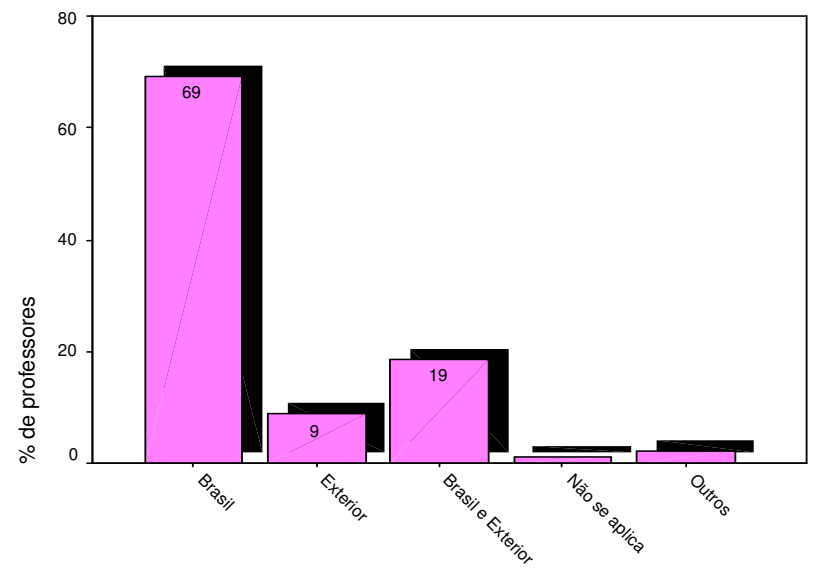

Tabela 5.4 - Classificação por Local de aprendizado do idioma: distribuição de freqüência

\begin{tabular}{|l|r|r|r|}
\hline & Freqüência & Percentual & $\begin{array}{r}\text { Percentual } \\
\text { Acumulado }\end{array}$ \\
\hline Brasil & 63 & 69,2 & 69,2 \\
Exterior & 8 & 8,8 & 78,0 \\
Brasil e Exterior & 17 & 18,7 & 96,7 \\
Não se aplica & 1 & 1,1 & 97,8 \\
Outros & 2 & 2,2 & 100,0 \\
Total & 91 & 100,0 & \\
\hline
\end{tabular}

Foi solicitado que respondessem há quanto tempo são professores de inglês. O gráfico 5.8 mostra que a amostra é composta de pessoas que lecionam há até 10 anos, representando $62,2 \%$ do total.

Gráfico 5.8 - Classificação por Tempo (anos) que exercem a profissão

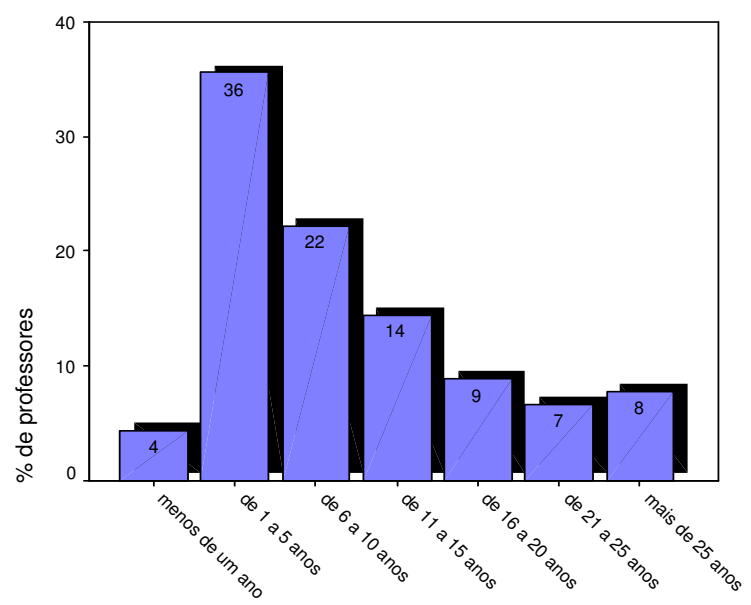


Tabela 5.5 - Classificação por Tempo: distribuição de freqüência

\begin{tabular}{|l|r|r|r|r|}
\hline & Freqüência & Percentual & $\begin{array}{c}\text { Valid } \\
\text { Percent }\end{array}$ & $\begin{array}{r}\text { Percentual } \\
\text { Acumulado }\end{array}$ \\
\hline menos de um ano & 4 & 4,4 & 4,4 & 4,4 \\
de 1 a 5 anos & 32 & 35,2 & 35,6 & 40,0 \\
de 6 a 10 anos & 20 & 22,0 & 22,2 & 62,2 \\
de 11 a 15 anos & 13 & 14,3 & 14,4 & 76,7 \\
de 16 a 20 anos & 8 & 8,8 & 8,9 & 85,6 \\
de 21 a 25 anos & 6 & 6,6 & 6,7 & 92,2 \\
mais de 25 anos & 7 & 7,7 & 7,8 & 100,0 \\
Total & 90 & 98,9 & 100,0 & \\
não informado & 1 & 1,1 & & \\
Total & 91 & 100,0 & & \\
\hline
\end{tabular}

Quando lhes foi perguntado sobre a existência de outra atividade, ou seja, se além de professores de inglês exerciam outra ocupação, a resposta foi de 59,3\% afirmando que não possuem outra ocupação e 38,5\% afirmaram que possuem outra ocupação (Gráfico 5.9). As outras ocupações informadas pelos 35 respondentes são: advogado, coordenador pedagógico, diretora financeira, dona-de-casa, mãe, esposa, secretária particular, doutorando, estagiário em psicologia do trabalho e em psicologia clínica, estudante, estudante de mestrado, monitora da faculdade, orientadora pedagógica, professor de português para estrangeiros, professora de artes, revisora, revisora/tradutora, secretária bilíngüe, tradutor, intérprete e pesquisador, vendedora de produtos de beleza, artesã e cirurgiã dentista.

Gráfico 5.9 - Percentual de professores que possuem outra ocupação

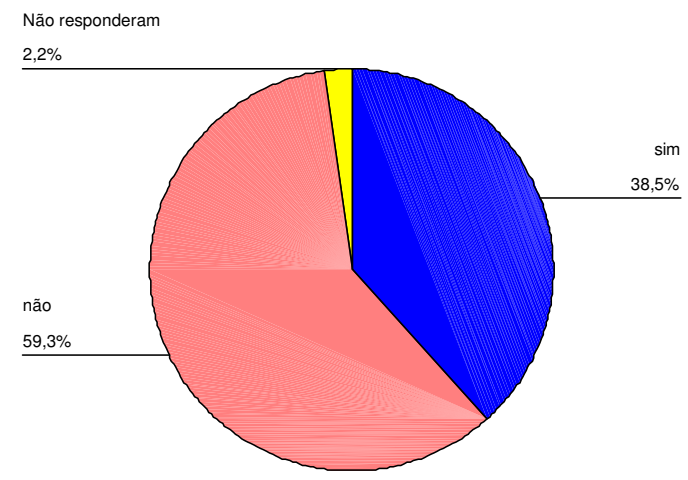


Tabela 5.6 - Distribuição de freqüência: professores que possuem outra ocupação

\begin{tabular}{|l|r|r|r|r|}
\hline & Freqüência & Percentual & $\begin{array}{c}\text { Percentual } \\
\text { Válido }\end{array}$ & $\begin{array}{r}\text { Percentual } \\
\text { Acumulado }\end{array}$ \\
\hline sim & 35 & 38,5 & 39,3 & 39,3 \\
não & 54 & 59,3 & 60,7 & 100,0 \\
Total & 89 & 97,8 & 100,0 & \\
Não responderam & 2 & 2,2 & & \\
Total & 91 & 100,0 & & \\
\hline
\end{tabular}

O grande número de respondentes deste estudo leciona na cidade de São Paulo, representando 54,9\% do total (Gráfico 5.10).

Gráfico 5.10 - Respondentes que lecionam em São Paulo

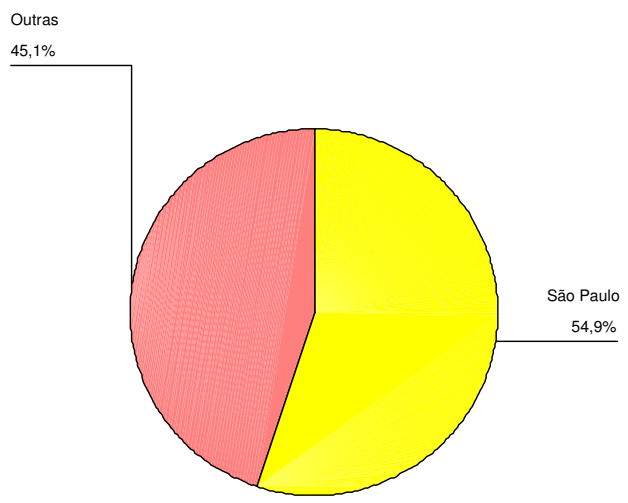

As demais cidades estão listadas a seguir:

Quadro 5.2 - Classificação por cidade onde lecionam

\begin{tabular}{|l|l|}
\hline \multicolumn{1}{|c|}{ Nome da cidade onde leciona } & $\begin{array}{c}\text { Quantidade } \\
\text { de } \\
\text { professores }\end{array}$ \\
\hline Rio de Janeiro - RJ & 6 \\
\hline Osasco - SP & 6 \\
\hline São Bernardo do Campo - SP & 3 \\
\hline Santo André - SP & 2 \\
\hline Salvador-BA & 2 \\
\hline Recife - PE & 2 \\
\hline Porto Alegre-RS & 2 \\
\hline Belo Horizonte - MG & 2 \\
\hline Ubaí/MG & 1 \\
\hline São José dos Campos - SP & 1 \\
\hline São Caetano do Sul - SP & 1 \\
\hline Rio Negrinho - SC & 1 \\
\hline Ribeirão Preto - SP & 1 \\
\hline Pedro Leopoldo e Lagoa Santa/MG & 1 \\
\hline Patos-PB & 1 \\
\hline Palmas-TO & 1 \\
\hline Niterói - RJ & 1 \\
\hline Mairiporã - SP & 1 \\
\hline Londrina-PR & 1 \\
\hline Itajubá e Pouso Alegre - MG & 1 \\
\hline Fortaleza - CE & 1 \\
\hline Curitiba - PR & 1 \\
\hline Carapicuíba - SP & 1 \\
\hline Barueri - SP & 1 \\
\hline Total & $\mathbf{4 1}$ \\
\hline & \\
\hline & 2 \\
\hline
\end{tabular}


Tabela 5.7 - Distribuição de freqüência das cidades que os respondentes lecionam

\begin{tabular}{|l|r|r|r|}
\hline & Freqüência & Percentual & $\begin{array}{r}\text { Percentual } \\
\text { acumulado }\end{array}$ \\
\hline São Paulo & 50 & 54,9 & 54,9 \\
Outras & 41 & 45,1 & 100,0 \\
Total & 91 & 100,0 & \\
\hline
\end{tabular}

Mais de 70\% (Gráfico 5.11) da amostra não está vinculada a nenhum sindicato ou associação, ilustrando o que Pochmann (1997) relata sobre a ausência dos sindicatos nas decisões empresariais sobre o padrão de emprego e uso do trabalho.

Gráfico 5.11 - Professores que estão vinculados a algum sindicato ou associação

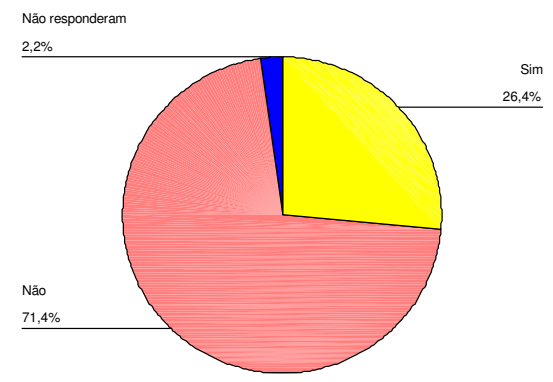

Tabela 5.8 - Distribuição de frequiência da associação a alguma entidade

\begin{tabular}{|c|c|c|c|c|c|}
\hline & & Frequeencia & Percentual & $\begin{array}{l}\text { Percentual } \\
\text { Válido }\end{array}$ & $\begin{array}{l}\text { Percentual } \\
\text { acumulado }\end{array}$ \\
\hline & Sim & 24 & 26,4 & 27,0 & 27,0 \\
\hline & Não & 65 & 71,4 & 73,0 & 100,0 \\
\hline & Total & 89 & 97,8 & 100,0 & \\
\hline Não responderam & & 2 & 2,2 & & \\
\hline Total & & 91 & 100,0 & & \\
\hline
\end{tabular}

Neste estudo, vê-se a predominância dos professores empregados sob a Consolidação das Leis de Trabalho (CLT), mas cabe destacar que os professores de inglês podem estar vinculados a mais de um regime de trabalho; porém, o que foi computado no Gráfico 5.12 são os regimes nos quais os professores dedicam o maior número de aulas. 
Gráfico 5.12 - Classificação por Regime de Trabalho

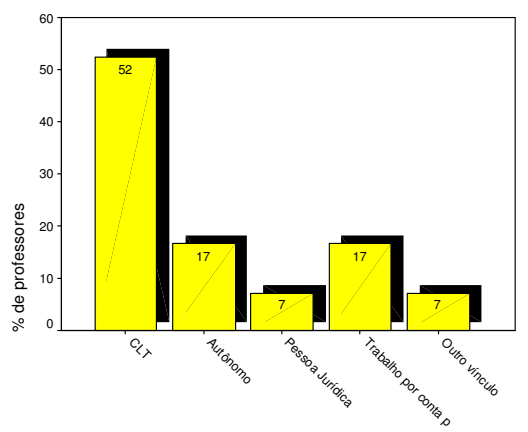

Considerando o Conceito de QVT, chegou-se aos seguintes resultados:

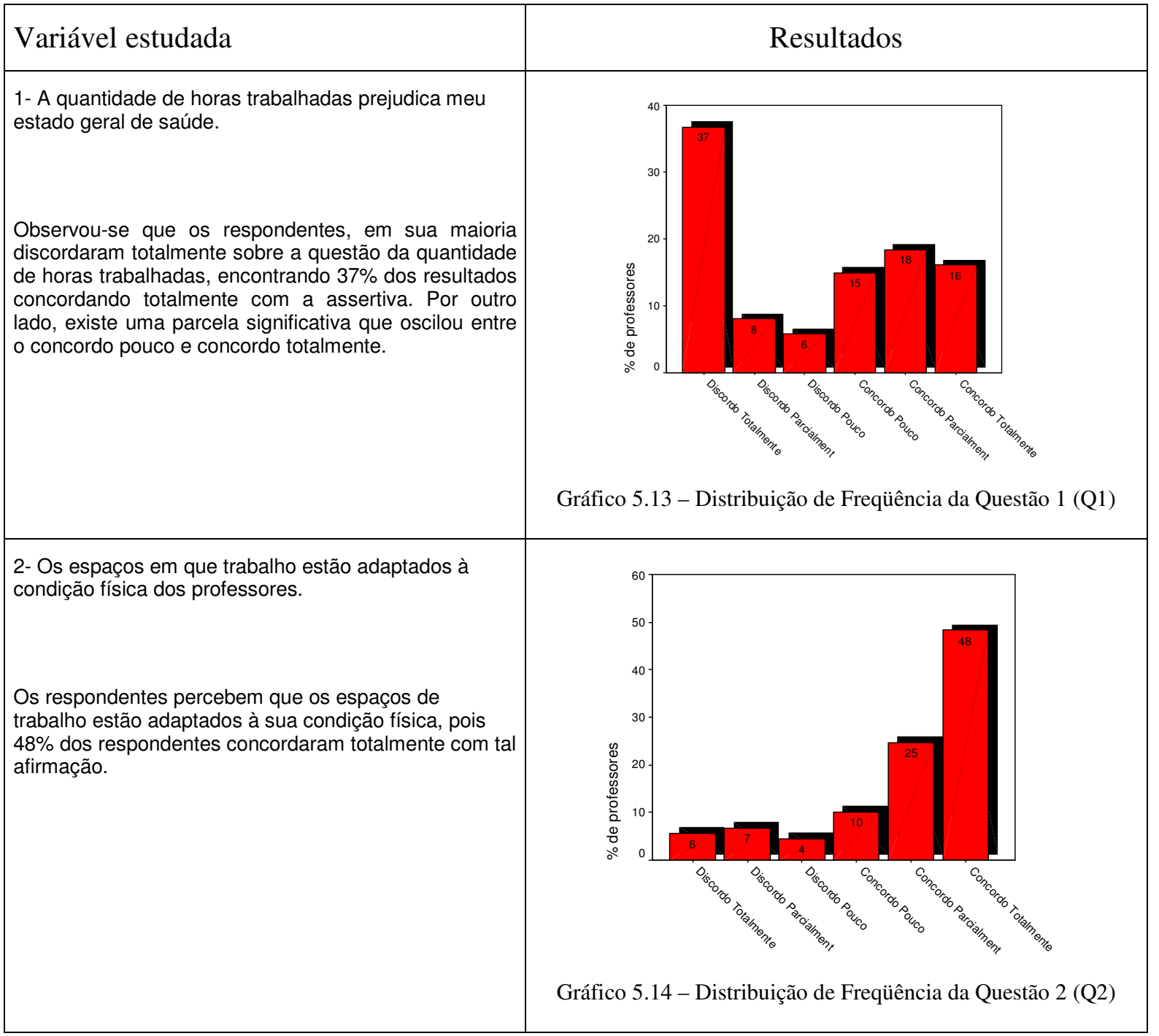




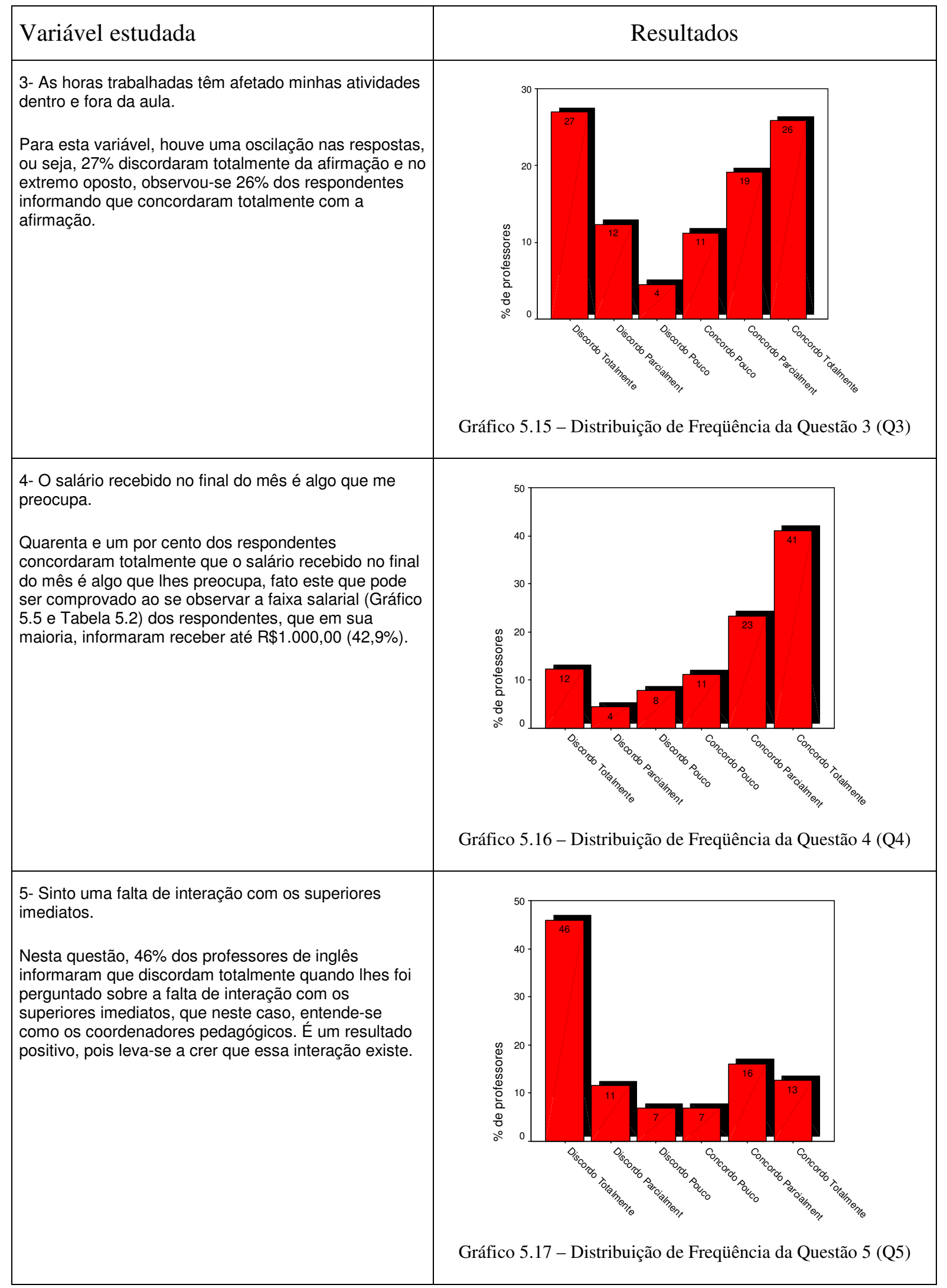




\begin{tabular}{|c|c|}
\hline Variável estudada & Resultados \\
\hline $\begin{array}{l}\text { 6- Seria interessante termos mais eventos culturais } \\
\text { envolvendo os professores. } \\
\text { Os professores de inglês concordaram totalmente que } \\
\text { gostariam que houvesse mais eventos culturais, pois } \\
49 \% \text { foram favoráveis a isso. }\end{array}$ & Gráfico $5.18-$ Distribuição de Frequiência da Questão 6 (Q6) \\
\hline $\begin{array}{l}\text { 7- Considero a flexibilidade de horário como algo } \\
\text { positivo, pois posso trabalhar em horários que me } \\
\text { permitam realizar outras atividades paralelamente. } \\
\text { Os professores de inglês concordaram totalmente } \\
(62 \%) \text { que a flexibilidade de horário é algo positivo no } \\
\text { seu trabalho, pois podem realizar outras atividades, } \\
\text { não estando "presos" a um horário de trabalho fixo. }\end{array}$ & Gráfico $5.19-$ Distribuição de Frequiência da Questão 7 (Q7) \\
\hline $\begin{array}{l}\text { 8- Realizo muitas atividades ao mesmo tempo. } \\
\text { Quanto a esta assertiva, } 72 \% \text { dos respondentes } \\
\text { concordaram parcialmente e totalmente quanto às } \\
\text { atividades que realizam simultaneamente. É um dado } \\
\text { que é reforçado pela própria característica de } \\
\text { flexibilidade de horário. Isso faz com que os } \\
\text { professores acabem se comprometendo com outras } \\
\text { atividades nos espaços de tempo em que não estão } \\
\text { dando aulas. }\end{array}$ & Gráfico $5.20-$ Distribuição de Frequiência da Questão 8 (Q8) \\
\hline
\end{tabular}




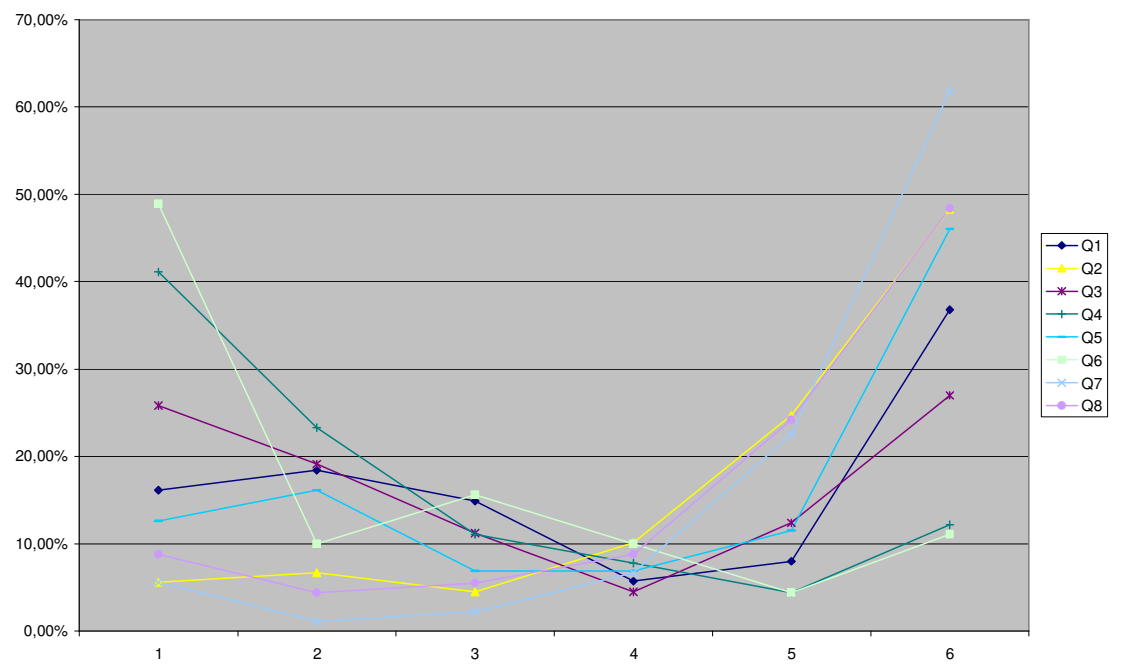

Gráfico 5.21 - Distribuição de Frequiência do Fator Crítico - Conceito de QVT

Com este resultado, observa-se, no gráfico 5.21, um resumo do bloco de questões que compuseram o conceito de QVT na ótica dos professores de inglês. Na percepção destes profissionais, as instituições em que atuam aplicam tal conceito, cabendo ressaltar apenas a questão salarial e a necessidade de mais eventos culturais. A tabela 5.9 abaixo resume o que foi comentado anteriormente.

Tabela 5.9 - Medidas de posição e dispersão das variáveis integrantes do Conceito de QVT

\begin{tabular}{|c|c|r|r|r|r|r|r|r|r|r|}
\hline & & $\mathbf{1}$ & $\mathbf{2}$ & $\mathbf{4}$ & $\mathbf{5}$ & $\mathbf{6}$ & Total & Média & Desvio-Padrão \\
\hline Q1 & $\mathrm{N}$ & 14 & 16 & 13 & 5 & 7 & 32 & 87 & 3,8161 & 1,9738 \\
& $\%$ & $16,1 \%$ & $18,4 \%$ & $14,9 \%$ & $5,7 \%$ & $8,0 \%$ & $36,8 \%$ & $100 \%$ & & \\
\hline Q2 & $\mathrm{N}$ & 5 & 6 & 4 & 9 & 22 & 43 & 89 & 4,8652 & 1,5090 \\
& $\%$ & $5,6 \%$ & $6,7 \%$ & $4,5 \%$ & $10,1 \%$ & $24,7 \%$ & $48,3 \%$ & $100 \%$ & & \\
\hline Q3 & $\mathrm{N}$ & 23 & 17 & 10 & 4 & 11 & 24 & 89 & 3,3933 & 2,0205 \\
& $\%$ & $25,8 \%$ & $19,1 \%$ & $11,2 \%$ & $4,5 \%$ & $12,4 \%$ & $27,0 \%$ & $100 \%$ & & \\
\hline Q4 & $\mathrm{N}$ & 37 & 21 & 10 & 7 & 4 & 11 & 90 & 2,4778 & 1,7303 \\
& $\%$ & $41,1 \%$ & $23,3 \%$ & $11,1 \%$ & $7,8 \%$ & $4,4 \%$ & $12,2 \%$ & $100 \%$ & & \\
\hline Q5 & $\mathrm{N}$ & 11 & 14 & 6 & 6 & 10 & 40 & 87 & 4,2644 & 1,9437 \\
& $\%$ & $12,6 \%$ & $16,1 \%$ & $6,9 \%$ & $6,9 \%$ & $11,5 \%$ & $46,0 \%$ & $100 \%$ & & \\
\hline Q6 & $\mathrm{N}$ & 44 & 9 & 14 & 9 & 4 & 10 & 90 & 2,4444 & 1,7489 \\
\hline Q7 & $\%$ & $48,9 \%$ & $10,0 \%$ & $15,6 \%$ & $10,0 \%$ & $4,4 \%$ & $11,1 \%$ & $100 \%$ & & \\
\hline Q8 & $\%$ & 5 & 1 & 2 & 6 & 20 & 55 & 89 & 5,2472 & 1,3167 \\
\hline & N & $8,6 \%$ & $1,1 \%$ & $2,2 \%$ & $6,7 \%$ & $22,5 \%$ & $61,8 \%$ & $100 \%$ & & \\
\hline
\end{tabular}


Quanto às variáveis geradas a partir do entendimento da visão BPSO-96, observa-se o seguinte resultado sobre a questão de Produtividade:

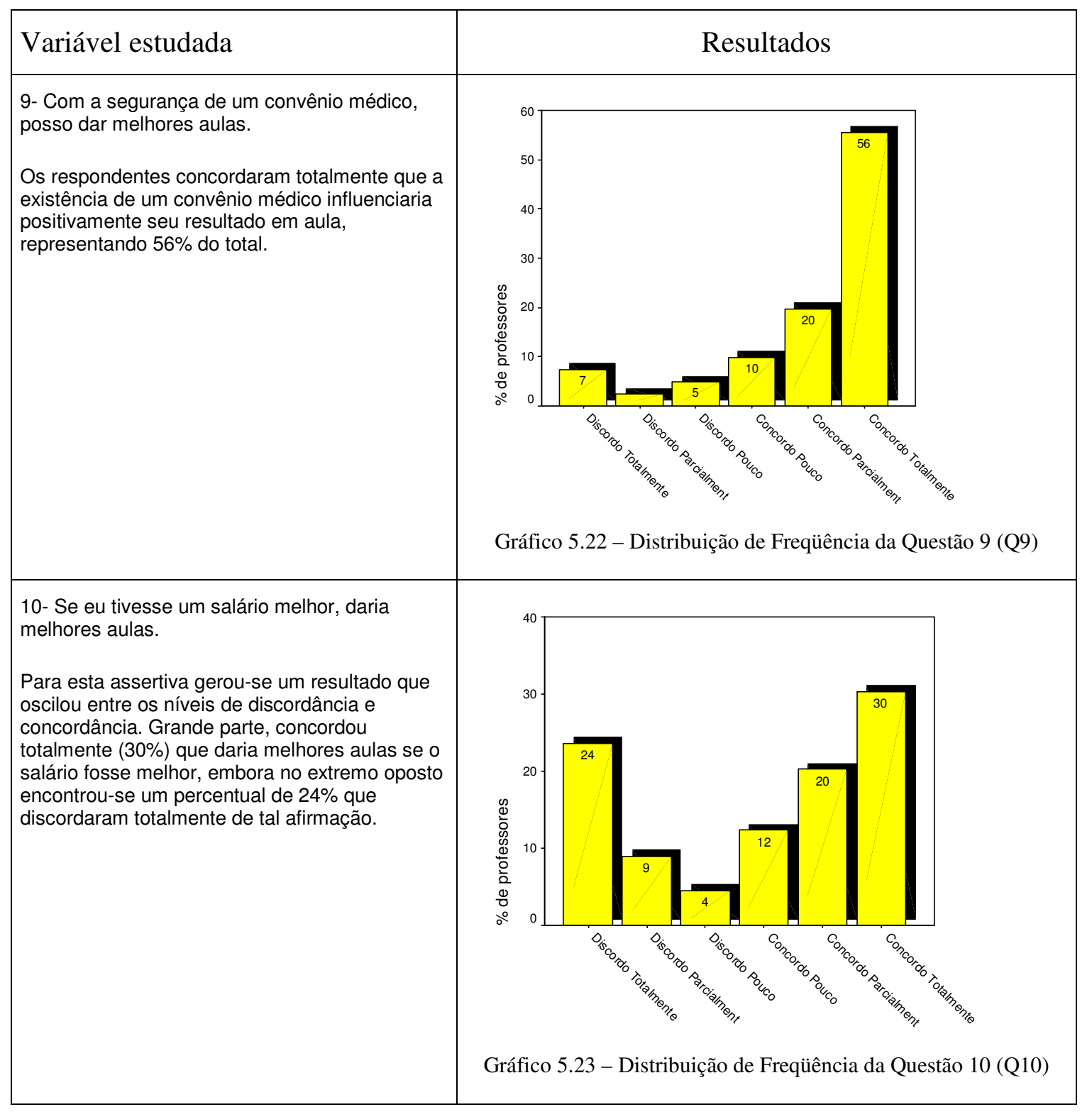




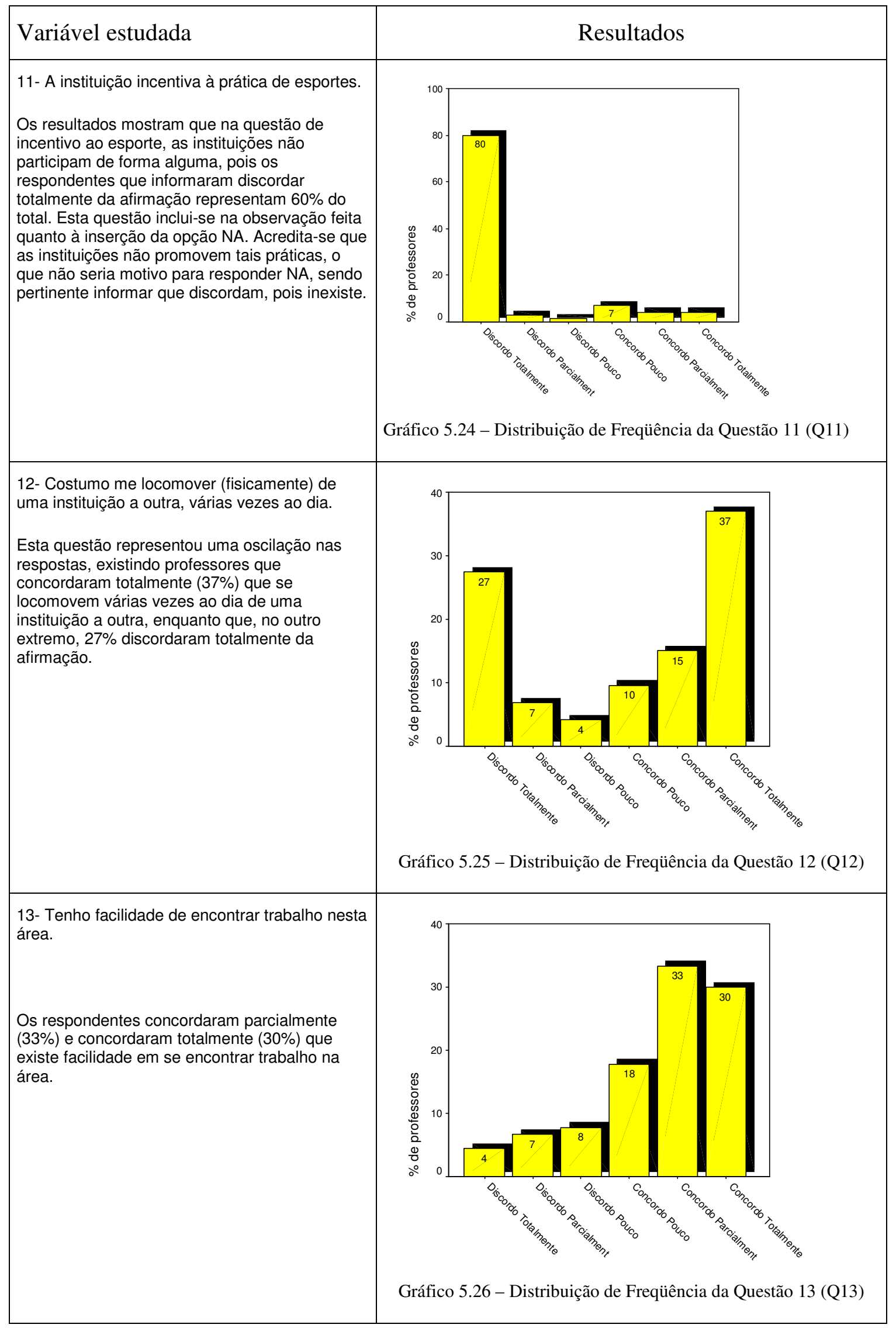




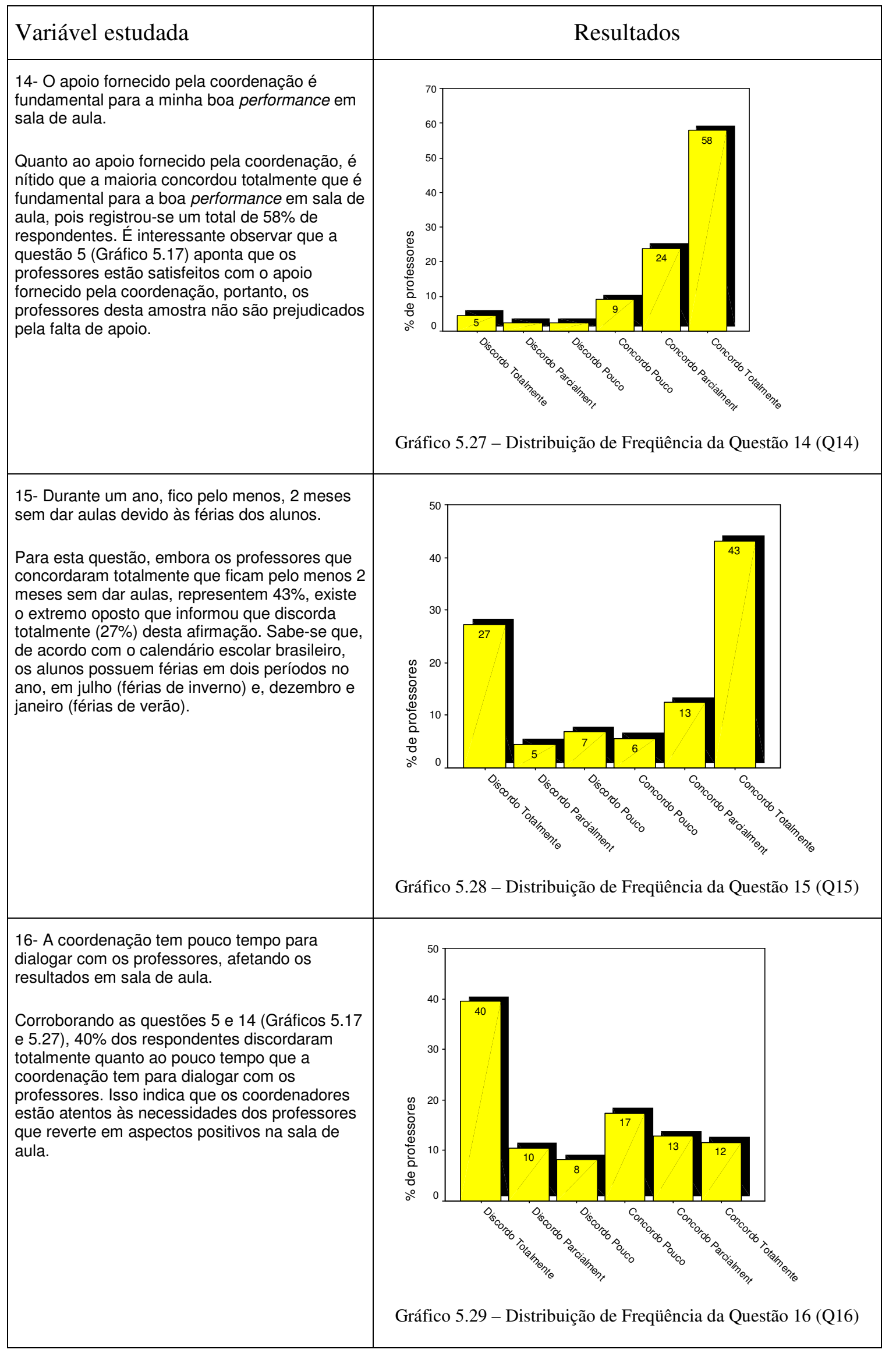



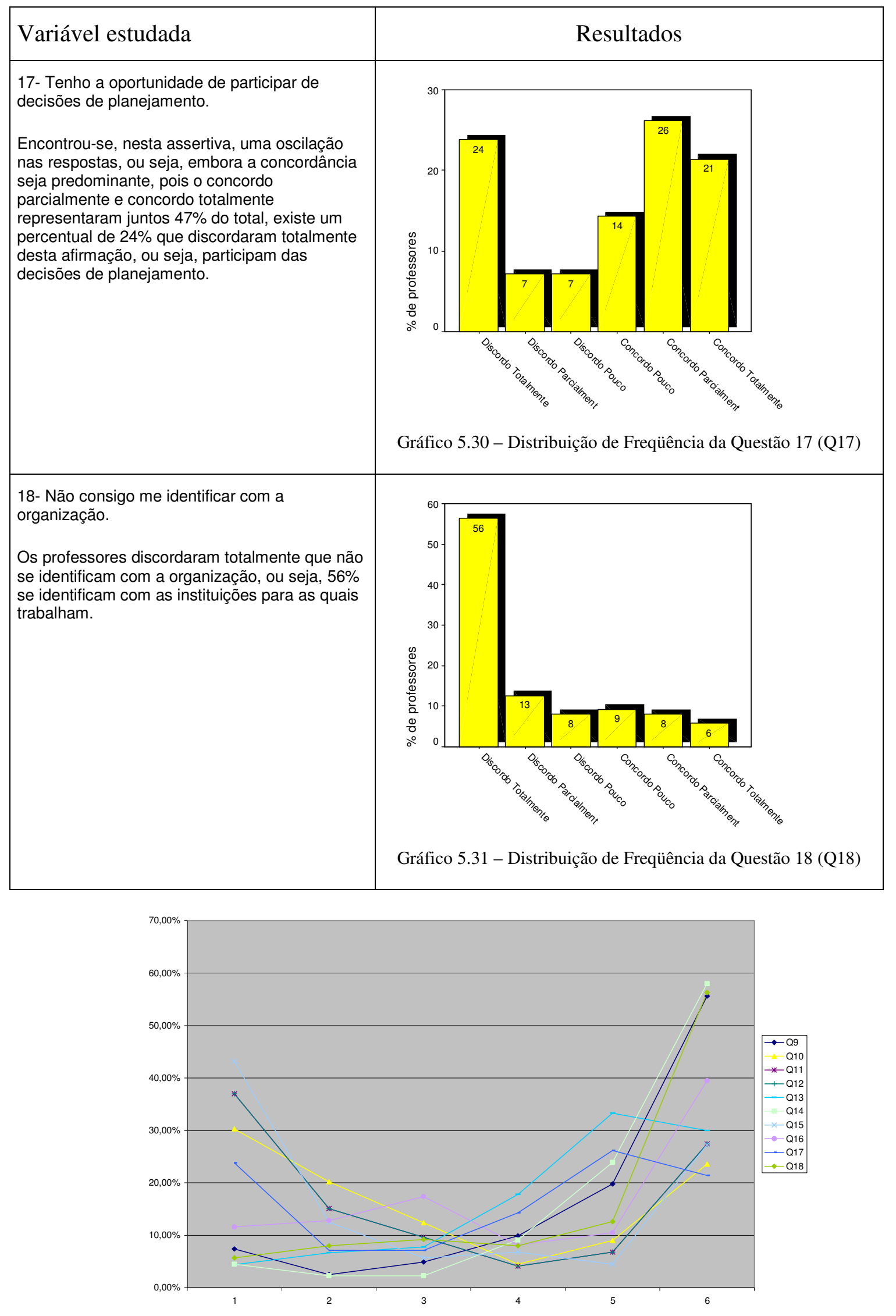

Gráfico 5.32 - Distribuição de Freqüência do fator Crítico - Produtividade 
Nessa linha de análise, observa-se no gráfico 5.32 que quanto ao fator crítico Produtividade, as questões procuraram representar aspectos pelos quais o desempenho em sala de aula é afetado, e observou-se que apenas a questão de incentivo ao esporte (Q11) e o período de férias sem aulas (Q15) é que são críticos para esses professores.

Tabela 5.10 - Medidas de posição e dispersão das variáveis integrantes do fator crítico Produtividade

\begin{tabular}{|c|c|c|c|c|c|c|c|c|c|c|}
\hline & & 1 & 2 & 3 & 4 & 5 & 6 & Total & Média & $\begin{array}{l}\text { Desvio- } \\
\text { padrão }\end{array}$ \\
\hline \multirow[t]{2}{*}{ Q9 } & $\mathrm{N}$ & 6 & 2 & 4 & 8 & 16 & 45 & 81 & 4,9877 & 1,5124 \\
\hline & $\%$ & $7,4 \%$ & $2,5 \%$ & $4,9 \%$ & $9,9 \%$ & $19,8 \%$ & $55,6 \%$ & $100,0 \%$ & & \\
\hline \multirow[t]{2}{*}{ Q10 } & $\mathrm{N}$ & 27 & 18 & 11 & 4 & 8 & 21 & 89 & 3,1236 & 1,9933 \\
\hline & $\%$ & $30,3 \%$ & $20,2 \%$ & $12,4 \%$ & $4,5 \%$ & $9,0 \%$ & $23,6 \%$ & $100,0 \%$ & & \\
\hline \multirow[t]{2}{*}{ Q11 } & $\mathrm{N}$ & 56 & 2 & 1 & 5 & 3 & 3 & 70 & 1,6571 & 1,4435 \\
\hline & $\%$ & $80,0 \%$ & $2,9 \%$ & $1,4 \%$ & $7,1 \%$ & $4,3 \%$ & $4,3 \%$ & $100,0 \%$ & & \\
\hline \multirow[t]{2}{*}{ Q12 } & $\mathrm{N}$ & 27 & 11 & 7 & 3 & 5 & 20 & 73 & 3,1096 & 2,1119 \\
\hline & $\%$ & $37,0 \%$ & $15,1 \%$ & $9,6 \%$ & $4,1 \%$ & $6,8 \%$ & $27,4 \%$ & $100,0 \%$ & & \\
\hline \multirow[t]{2}{*}{ Q13 } & $\mathrm{N}$ & 4 & 6 & 7 & 16 & 30 & 27 & 90 & 4,5889 & 1,3974 \\
\hline & $\%$ & $4,4 \%$ & $6,7 \%$ & $7,8 \%$ & $17,8 \%$ & $33,3 \%$ & $30,0 \%$ & $100,0 \%$ & & \\
\hline \multirow[t]{2}{*}{ Q14 } & $\mathrm{N}$ & 4 & 2 & 2 & 8 & 21 & 51 & 88 & 5,1932 & 1,2942 \\
\hline & $\%$ & $4,5 \%$ & $2,3 \%$ & $2,3 \%$ & $9,1 \%$ & $23,9 \%$ & $58,0 \%$ & $100,0 \%$ & & \\
\hline \multirow[t]{2}{*}{ Q15 } & $\mathrm{N}$ & 38 & 11 & 5 & 6 & 4 & 24 & 88 & 2,9886 & 2,1469 \\
\hline & $\%$ & $43,2 \%$ & $12,5 \%$ & $5,7 \%$ & $6,8 \%$ & $4,5 \%$ & $27,3 \%$ & $100,0 \%$ & & \\
\hline \multirow[t]{2}{*}{ Q16 } & $\mathrm{N}$ & 10 & 11 & 15 & 7 & 9 & 34 & 86 & 4,1163 & 1,8561 \\
\hline & $\%$ & $11,6 \%$ & $12,8 \%$ & $17,4 \%$ & $8,1 \%$ & $10,5 \%$ & $39,5 \%$ & $100,0 \%$ & & \\
\hline \multirow[t]{2}{*}{ Q17 } & $\mathrm{N}$ & 20 & 6 & 6 & 12 & 22 & 18 & 84 & 3,7619 & 1,8988 \\
\hline & $\%$ & $23,8 \%$ & $7,1 \%$ & $7,1 \%$ & $14,3 \%$ & $26,2 \%$ & $21,4 \%$ & $100,0 \%$ & & \\
\hline \multirow[t]{2}{*}{ Q18 } & $\mathrm{N}$ & 5 & 7 & 8 & 7 & 11 & 49 & 87 & 4,8276 & 1,6297 \\
\hline & $\%$ & $5,7 \%$ & $8,0 \%$ & $9,2 \%$ & $8,0 \%$ & $12,6 \%$ & $56,3 \%$ & $100,0 \%$ & & \\
\hline
\end{tabular}


Para o fator crítico Legitimidade gerou-se resultado a seguir:

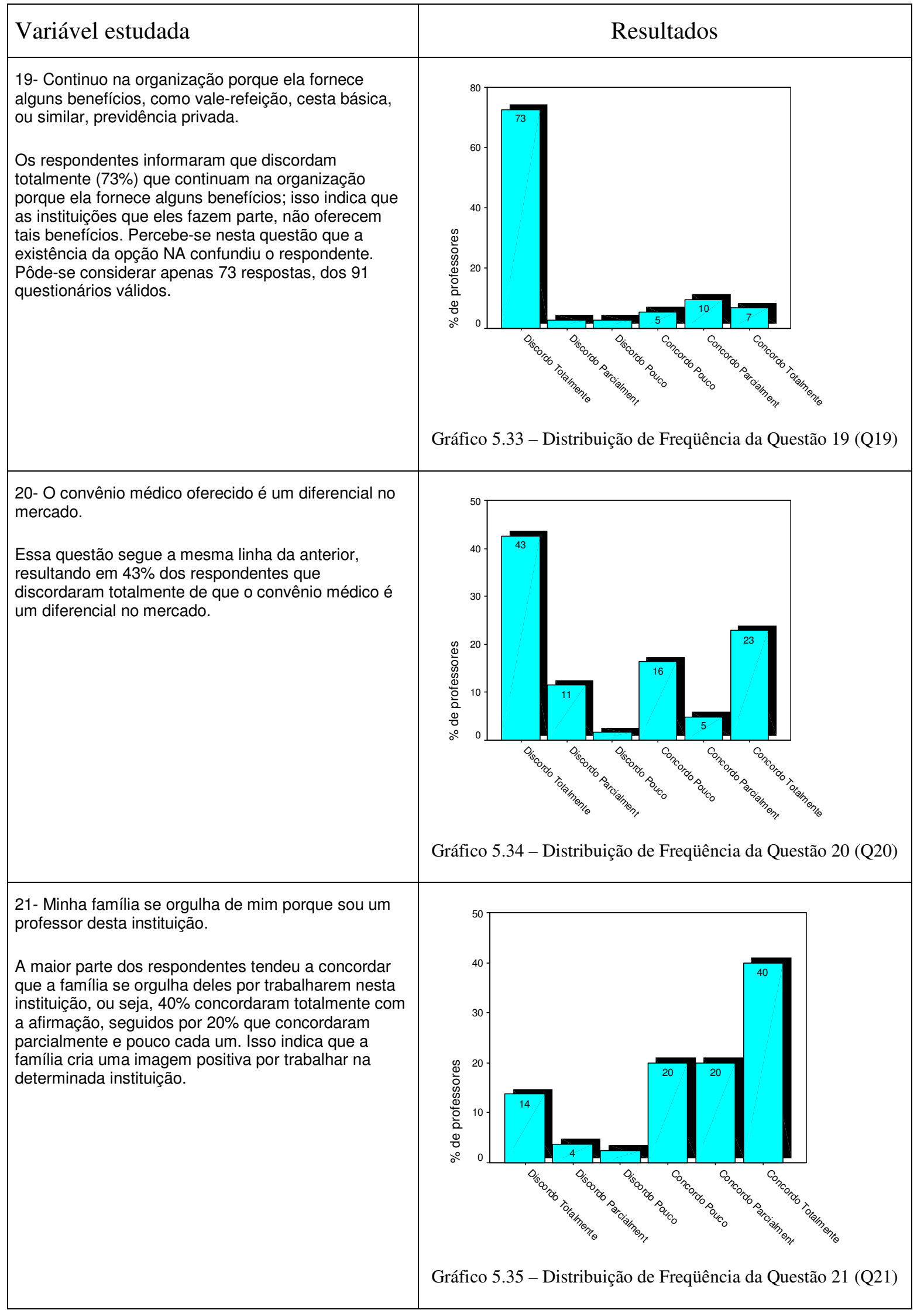




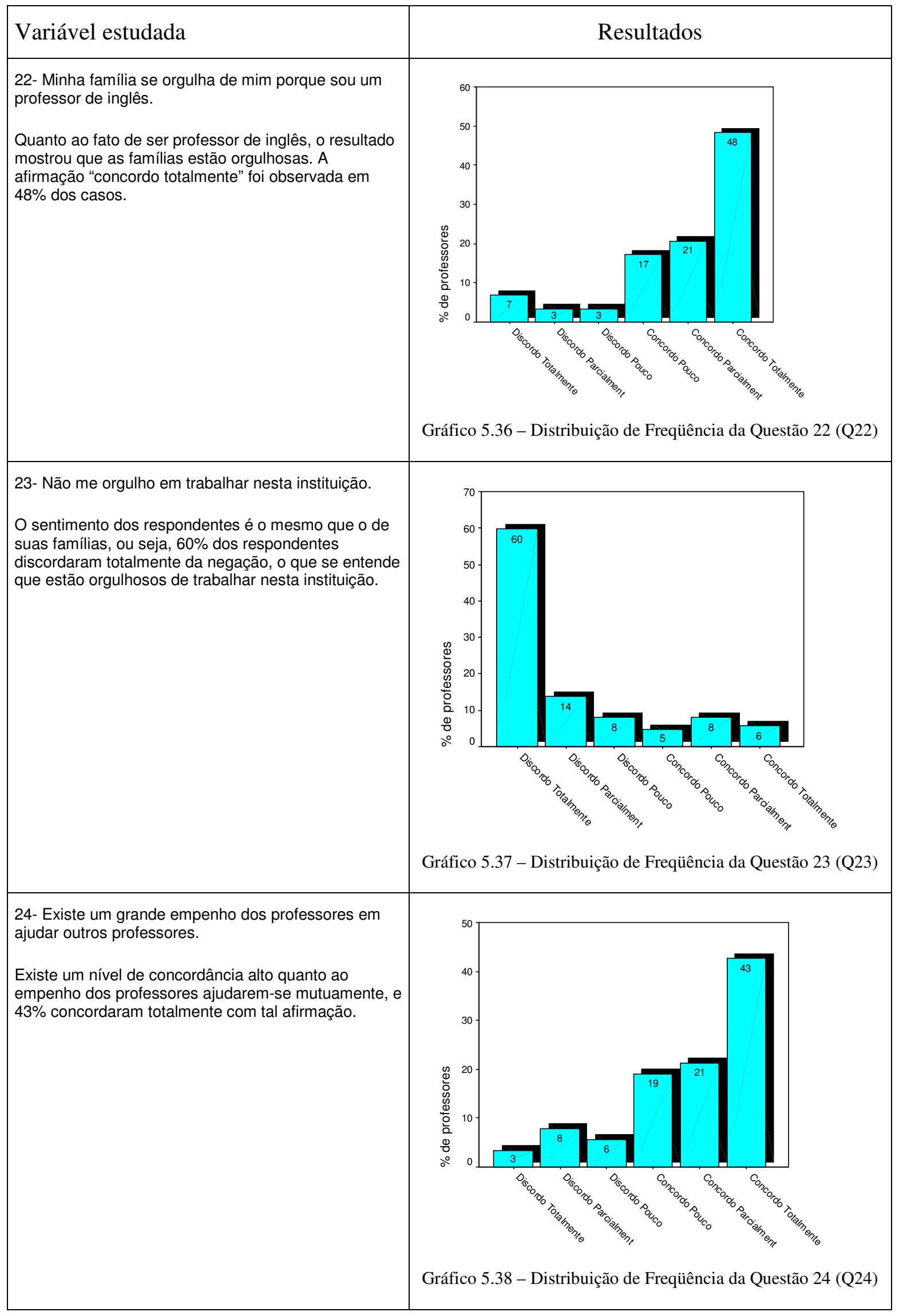




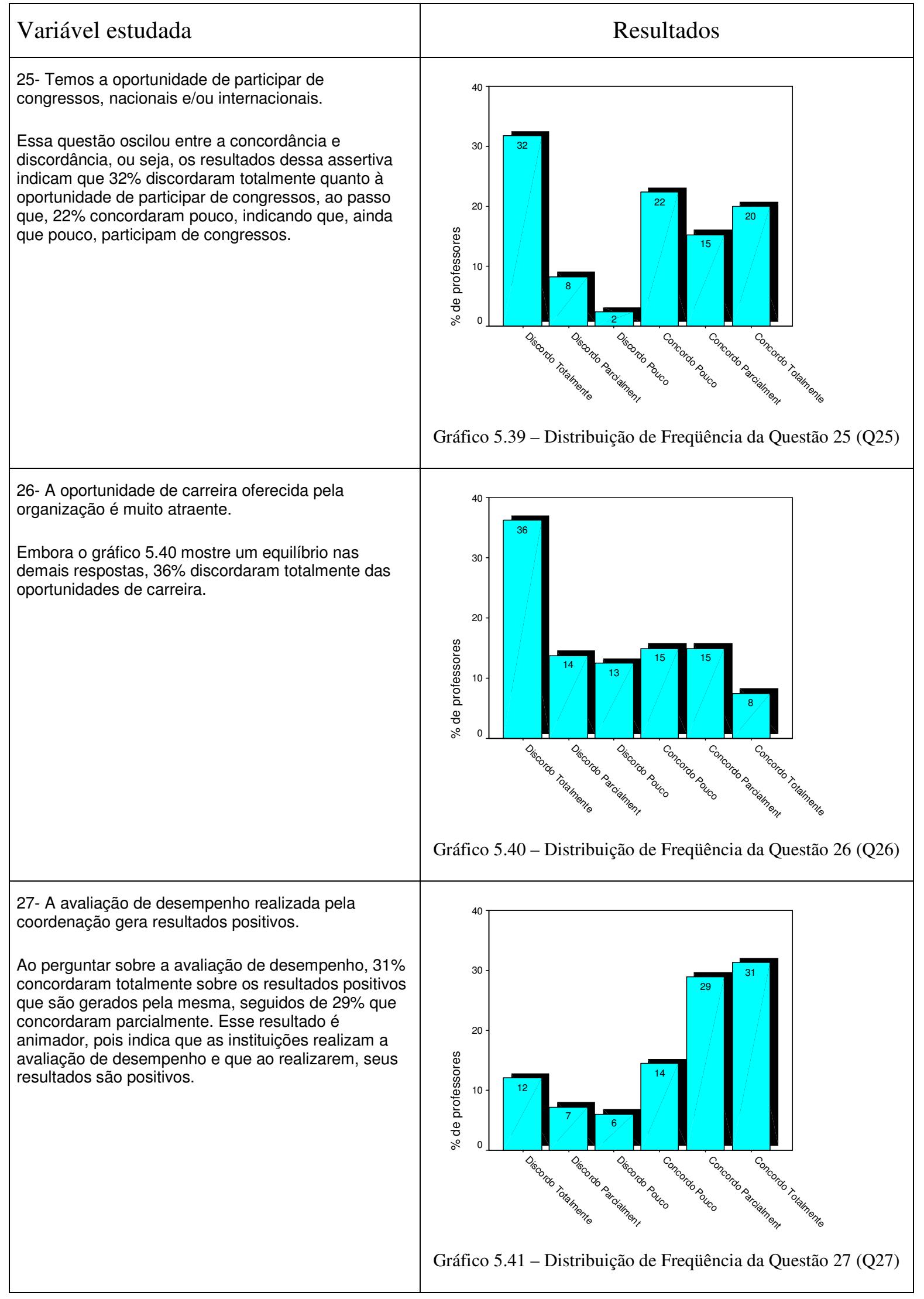




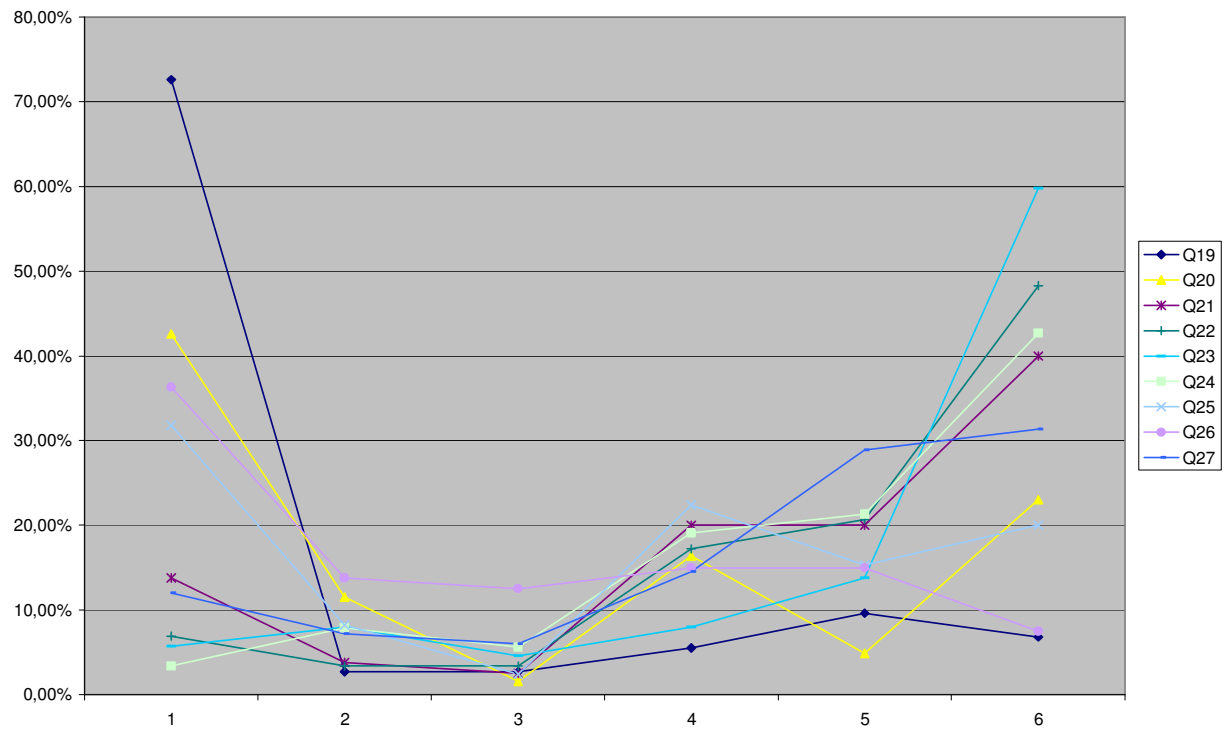

Gráfico 5.42 - Distribuição de Frequiência do Fator Crítico - Legitimidade

Ao se analisar de forma consolidada este fator crítico (Gráfico 5.42), a Legitimidade, observa-se que para que as ações sejam legítimas, é preciso que os professores reconheçam, não só o que lhes é oferecido e como lhes é oferecido, mas também sua própria imagem dentro da sociedade. Percebe-se com esse resultado, que as questões de saúde e carreira têm sido negligenciadas por parte das instituições (Q19, Q20 e Q26). 
Tabela 5.11 - Medidas de posição e dispersão das variáveis integrantes do fator crítico Legitimidade

\begin{tabular}{|c|c|r|r|r|r|r|r|r|r|r|}
\hline & & $\mathbf{1}$ & $\mathbf{3}$ & $\mathbf{4}$ & $\mathbf{5}$ & $\mathbf{6}$ & Total & Média & Desvio-padrão \\
\hline Q19 & $\mathrm{N}$ & 53 & 2 & 2 & 4 & 7 & 5 & 73 & 1,9726 & 1,7238 \\
& $\%$ & $72,6 \%$ & $2,7 \%$ & $2,7 \%$ & $5,5 \%$ & $9,6 \%$ & $6,8 \%$ & $100,0 \%$ & & \\
\hline Q20 & $\mathrm{N}$ & 26 & 7 & 1 & 10 & 3 & 14 & 61 & 2,9836 & 2,0776 \\
& $\%$ & $42,6 \%$ & $11,5 \%$ & $1,6 \%$ & $16,4 \%$ & $4,9 \%$ & $23,0 \%$ & $100,0 \%$ & & \\
\hline Q21 & $\mathrm{N}$ & 11 & 3 & 2 & 16 & 16 & 32 & 80 & 4,4875 & 1,7357 \\
& $\%$ & $13,8 \%$ & $3,8 \%$ & $2,5 \%$ & $20,0 \%$ & $20,0 \%$ & $40,0 \%$ & $100,0 \%$ & & \\
\hline Q22 & $\mathrm{N}$ & 6 & 3 & 3 & 15 & 18 & 42 & 87 & 4,8621 & 1,4877 \\
& $\%$ & $6,9 \%$ & $3,4 \%$ & $3,4 \%$ & $17,2 \%$ & $20,7 \%$ & $48,3 \%$ & $100,0 \%$ & & \\
\hline Q23 & $\mathrm{N}$ & 5 & 7 & 4 & 7 & 12 & 52 & 87 & 4,9540 & 1,5915 \\
\hline \% & $\%$ & $5,7 \%$ & $8,0 \%$ & $4,6 \%$ & $8,0 \%$ & $13,8 \%$ & $59,8 \%$ & $100,0 \%$ & & \\
\hline Q24 & $\mathrm{N}$ & 3 & 7 & 5 & 17 & 19 & 38 & 89 & 4,7528 & 1,4324 \\
\hline & $\%$ & $3,4 \%$ & $7,9 \%$ & $5,6 \%$ & $19,1 \%$ & $21,3 \%$ & $42,7 \%$ & $100,0 \%$ & & \\
\hline Q25 & $\mathrm{N}$ & 27 & 7 & 2 & 19 & 13 & 17 & 85 & 3,4118 & 1,9657 \\
\hline & $\%$ & $31,8 \%$ & $8,2 \%$ & $2,4 \%$ & $22,4 \%$ & $15,3 \%$ & $20,0 \%$ & $100,0 \%$ & & \\
\hline Q26 & $\mathrm{N}$ & 29 & 11 & 10 & 12 & 12 & 6 & 80 & 2,8125 & 1,7364 \\
\hline
\end{tabular}

Com a definição do Perfil do Gestor, pôde-se encontrar alguns resultados, a saber:

\begin{tabular}{|c|c|}
\hline Variável estudada & Resultados \\
\hline $\begin{array}{l}\text { 28- O pessoal da coordenação entende que uma } \\
\text { boa saúde é fundamental para o bom } \\
\text { desempenho em sala de aula. } \\
\text { Embora não exista incentivo à prática de esportes } \\
\text { por parte das instituições, nem proteção à saúde } \\
\text { pela ausência de um bom convênio médico, fato } \\
\text { observado nas questões } 11 \text { e } 20 \text { (Gráficos } 5.24 \text { e } \\
5.34 \text { ), 39\% dos respondentes informaram que } \\
\text { concordam totalmente com a afirmação sobre o } \\
\text { reconhecimento da coordenação quanto à boa } \\
\text { saúde ser fundamental para o desempenho em } \\
\text { sala de aula. }\end{array}$ & Gráfico 5.43 - Distribuição de Frequiência da Questão $28(\mathrm{Q} 28)$ \\
\hline
\end{tabular}




\begin{tabular}{|c|c|}
\hline Variável estudada & Resultados \\
\hline $\begin{array}{l}\text { 29- O pessoal da coordenação sabe ouvir sempre } \\
\text { as sugestões dos professores. } \\
\text { O nível de concordância com essa questão foi } \\
\text { alto, representado por } 43 \% \text { dos respondentes que } \\
\text { concordaram totalmente, seguidos por } 31 \% \text { que } \\
\text { concordaram parcialmente que o pessoal da } \\
\text { coordenação sabe ouvir sugestões dos } \\
\text { professores. }\end{array}$ & Gráfico 5.44 - Distribuição de Frequiência da Questão 29 (Q29) \\
\hline $\begin{array}{l}\text { 30- Tenho um relacionamento satisfatório com } \\
\text { minha coordenação. } \\
\text { A grande maioria possui um relacionamento } \\
\text { satisfatório com a coordenação, representado por } \\
63 \% \text { do total que concordaram totalmente com tal } \\
\text { afirmação. }\end{array}$ & Gráfico 5.45 - Distribuição de Frequência da Questão 30 (Q30) \\
\hline $\begin{array}{l}\text { 31- Recebo apoio para realizar trabalhos junto à } \\
\text { comunidade. } \\
\text { Essa questão foi prejudicada com a opção do NA, } \\
\text { pois foram computados apenas } 65 \text { respostas, dos } \\
91 \text { questionários válidos. Trinta e oito por cento } \\
\text { responderam que discordam totalmente que existe } \\
\text { apoio para a realização de trabalhos junto à } \\
\text { comunidade. A existência da opção NA e o } \\
\text { elevado percentual de respostas pode ser } \\
\text { explicado justamente por essa falta de apoio. As } \\
\text { instituiçõos podem nunca ter mencionado tais } \\
\text { questōes, o que faz com que os professores } \\
\text { acreditem que esse posicionamento não se } \\
\text { aplique às suas realidades organizacionais, ou } \\
\text { seja, não cabe à empresa tratar das questôes da } \\
\text { comunidade. }\end{array}$ & 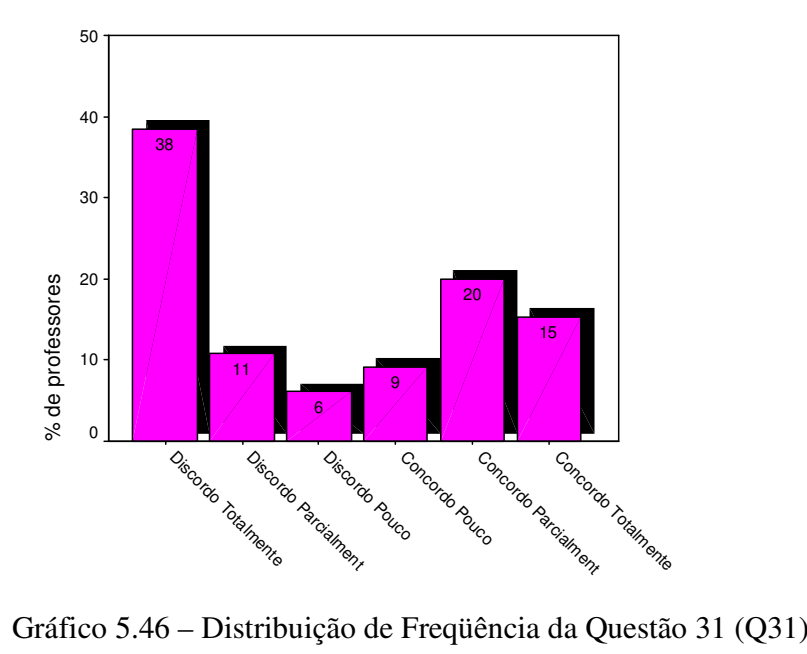 \\
\hline
\end{tabular}




\begin{tabular}{|c|c|}
\hline Variável estudada & Resultados \\
\hline $\begin{array}{l}\text { 32- A organização fornece financiamento de } \\
\text { cursos externos, que complementem a formação } \\
\text { do professor. } \\
\text { Há um nível de discordância alto nesta questão, } \\
\text { ou seja, } 59 \% \text { dos professores discordaram } \\
\text { totalmente quando lhes foi perguntado sobre o } \\
\text { financiamento de cursos externos que } \\
\text { complementam a formação do professor. Essa } \\
\text { questão corrobora com a questão } 26 \text { (Gráfico } \\
5.40 \text { ) sobre as oportunidades de carreira oferecida } \\
\text { pela organização. }\end{array}$ & Gráfico 5.47 - Distribuição de Frequiência da Questão 32 (Q32) \\
\hline $\begin{array}{l}\text { 33- Tenho a oportunidade de realizar outros } \\
\text { cursos de idiomas. } \\
\text { É interessante observar que } 48 \% \text { dos } \\
\text { respondentes concordaram totalmente que têm a } \\
\text { oportunidade de realizar outros cursos de idiomas, } \\
\text { embora, no outro extremo, ainda que um } \\
\text { percentual não tão alto quanto a concordância, } \\
29 \% \text { discordaram totalmente desta afirmação. }\end{array}$ & Gráfico $5.48-100$ \\
\hline
\end{tabular}

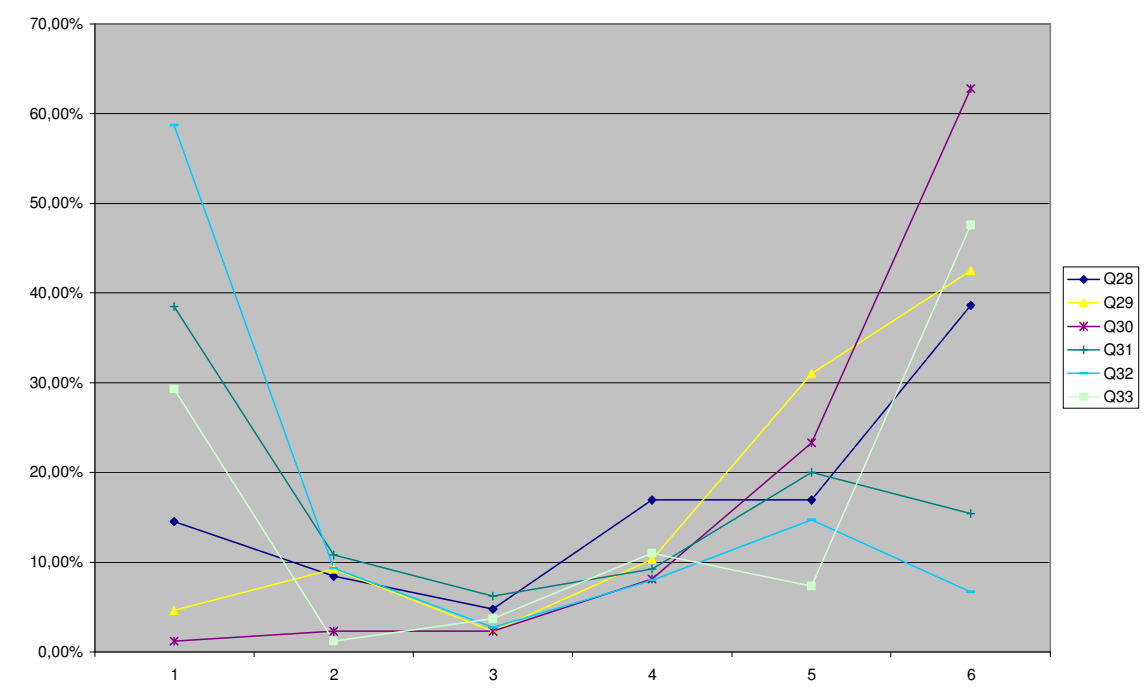

Gráfico 5.49 - Distribuição de Frequiência do Fator Crítico - Perfil do Gestor 
Quanto ao perfil do gestor, observou-se, através das questões $28,29,30$ e 33 , que as instituições possuem coordenadores com perfil de gestor nos aspectos mencionados; porém, a questão 31 , que se refere às questões de responsabilidade social, estão fora do perfil desses coordenadores. A questão 32 também foi respondida negativamente, passando a idéia da inexistência de preocupação dos coordenadores pelo desenvolvimento da pessoa. Dessa forma, o coordenador não é capaz de olhar de forma integrada ao processo de gestão, apresentando o perfil desejado em apenas alguns aspectos.

Tabela 5.12 - Medidas de posição e dispersão das variáveis integrantes do fator crítico Perfil do Gestor

\begin{tabular}{|c|c|c|c|c|c|c|c|c|c|c|}
\hline & & 1 & 2 & 3 & 4 & 5 & 6 & Total & Média & $\begin{array}{l}\text { Desvio- } \\
\text { padrão }\end{array}$ \\
\hline \multirow[t]{2}{*}{ Q28 } & $\mathrm{N}$ & 12 & 7 & 4 & 14 & 14 & 32 & 83 & 4,2892 & 1,8315 \\
\hline & $\%$ & $14,5 \%$ & $8,4 \%$ & $4,8 \%$ & $16,9 \%$ & $16,9 \%$ & $38,6 \%$ & $100,0 \%$ & & \\
\hline \multirow[t]{2}{*}{ Q29 } & $\mathrm{N}$ & 4 & 8 & 2 & 9 & 27 & 37 & 87 & 4,8161 & 1,4748 \\
\hline & $\%$ & $4,6 \%$ & $9,2 \%$ & $2,3 \%$ & $10,3 \%$ & $31,0 \%$ & $42,5 \%$ & $100,0 \%$ & & \\
\hline \multirow[t]{2}{*}{ Q30 } & $\mathrm{N}$ & 1 & 2 & 2 & 7 & 20 & 54 & 86 & 5,3837 & 1,0309 \\
\hline & $\%$ & $1,2 \%$ & $2,3 \%$ & $2,3 \%$ & $8,1 \%$ & $23,3 \%$ & $62,8 \%$ & $100,0 \%$ & & \\
\hline \multirow[t]{2}{*}{ Q31 } & $\mathrm{N}$ & 25 & 7 & 4 & 6 & 13 & 10 & 65 & 3,0769 & 1,9946 \\
\hline & $\%$ & $38,5 \%$ & $10,8 \%$ & $6,2 \%$ & $9,2 \%$ & $20,0 \%$ & $15,4 \%$ & $100,0 \%$ & & \\
\hline \multirow[t]{2}{*}{ Q32 } & $\mathrm{N}$ & 44 & 7 & 2 & 6 & 11 & 5 & 75 & 2,3067 & 1,8082 \\
\hline & $\%$ & $58,7 \%$ & $9,3 \%$ & $2,7 \%$ & $8,0 \%$ & $14,7 \%$ & $6,7 \%$ & $100,0 \%$ & & \\
\hline \multirow[t]{2}{*}{ Q33 } & $\mathrm{N}$ & 24 & 1 & 3 & 9 & 6 & 39 & 82 & 4,0854 & 2,1785 \\
\hline & $\%$ & $29,3 \%$ & $1,2 \%$ & $3,7 \%$ & $11,0 \%$ & $7,3 \%$ & $47,6 \%$ & $100,0 \%$ & & \\
\hline
\end{tabular}


Visando identificar as Práticas e Valores que a empresa realiza, obteve-se o resultado abaixo:

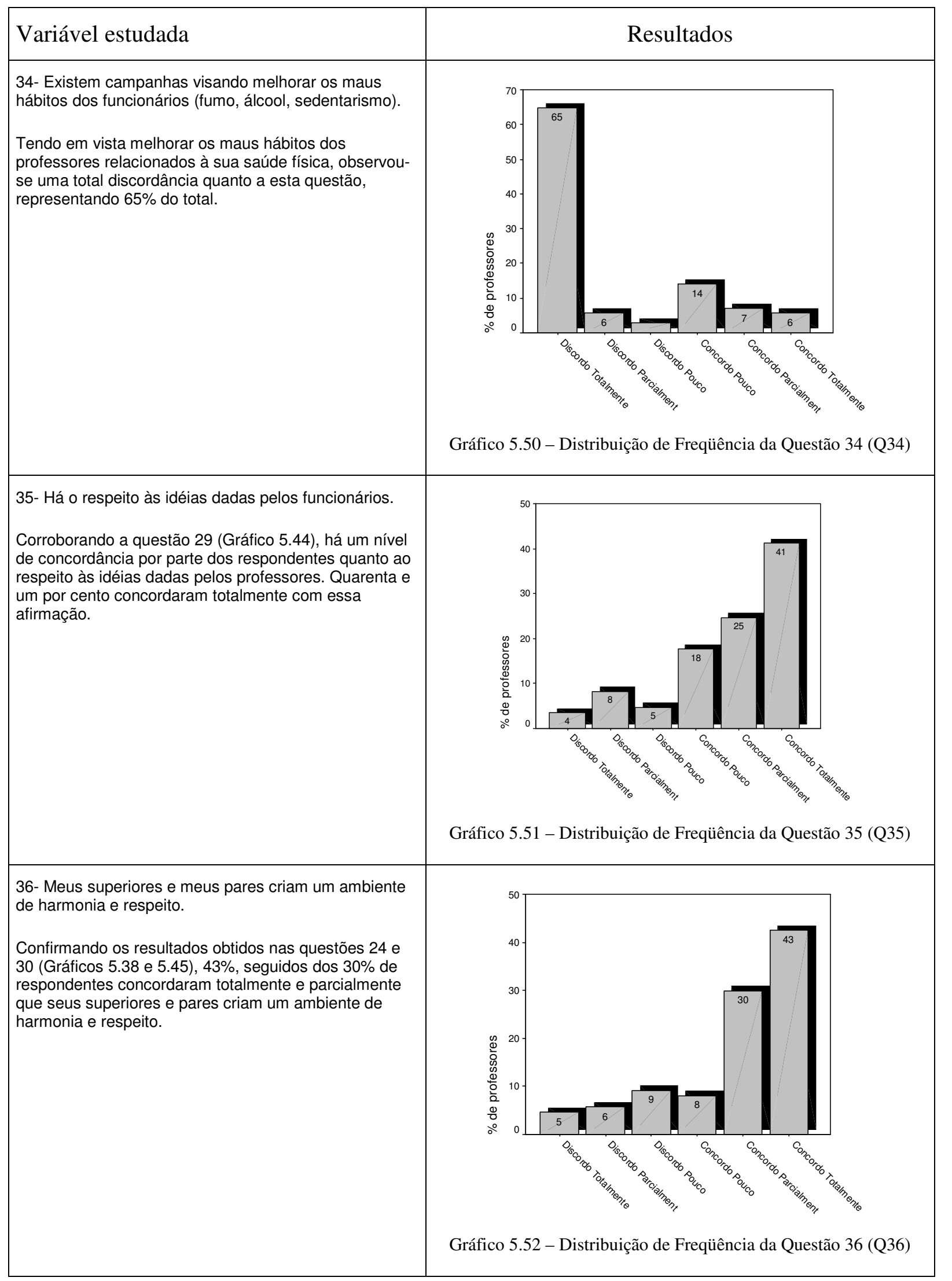




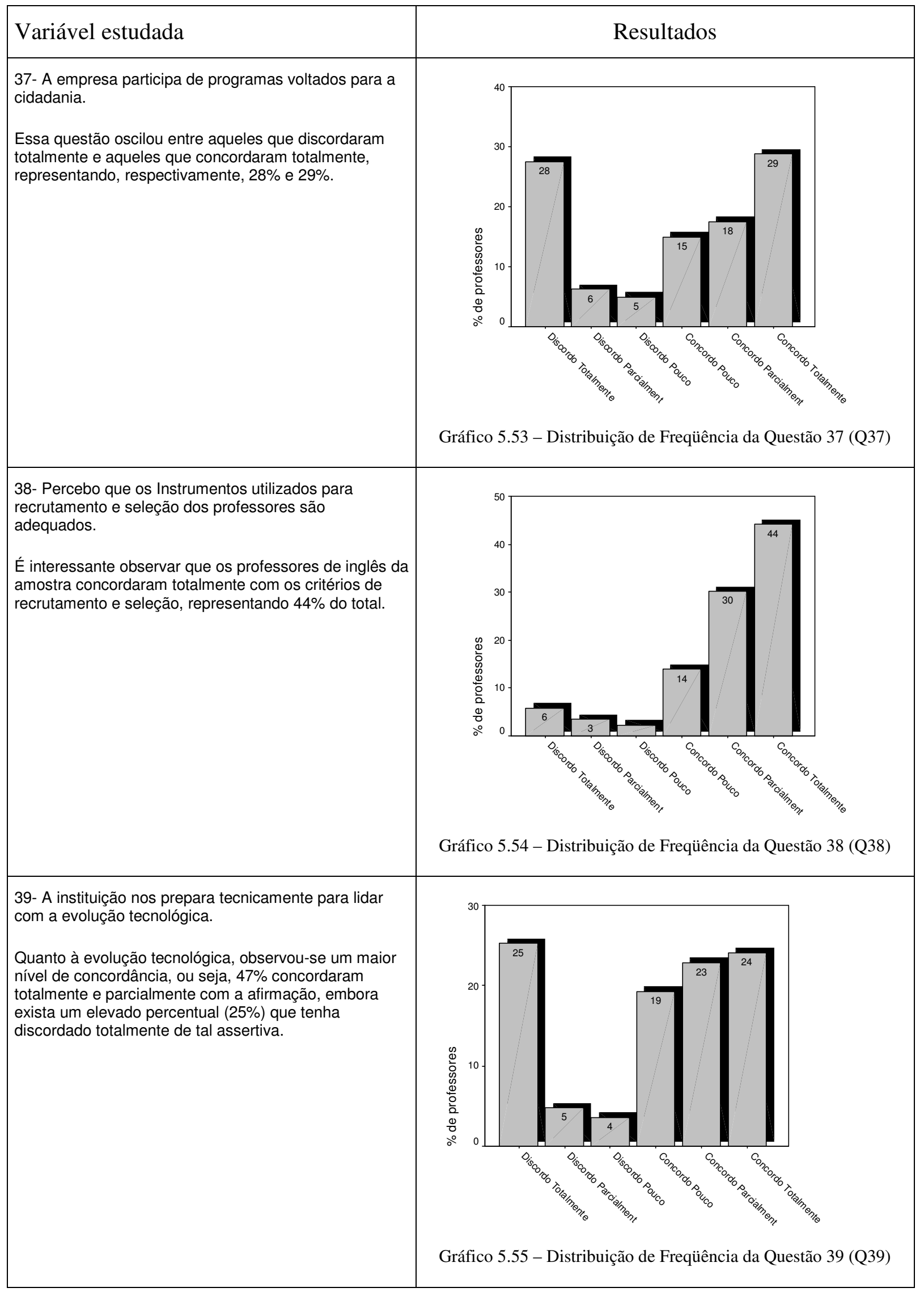




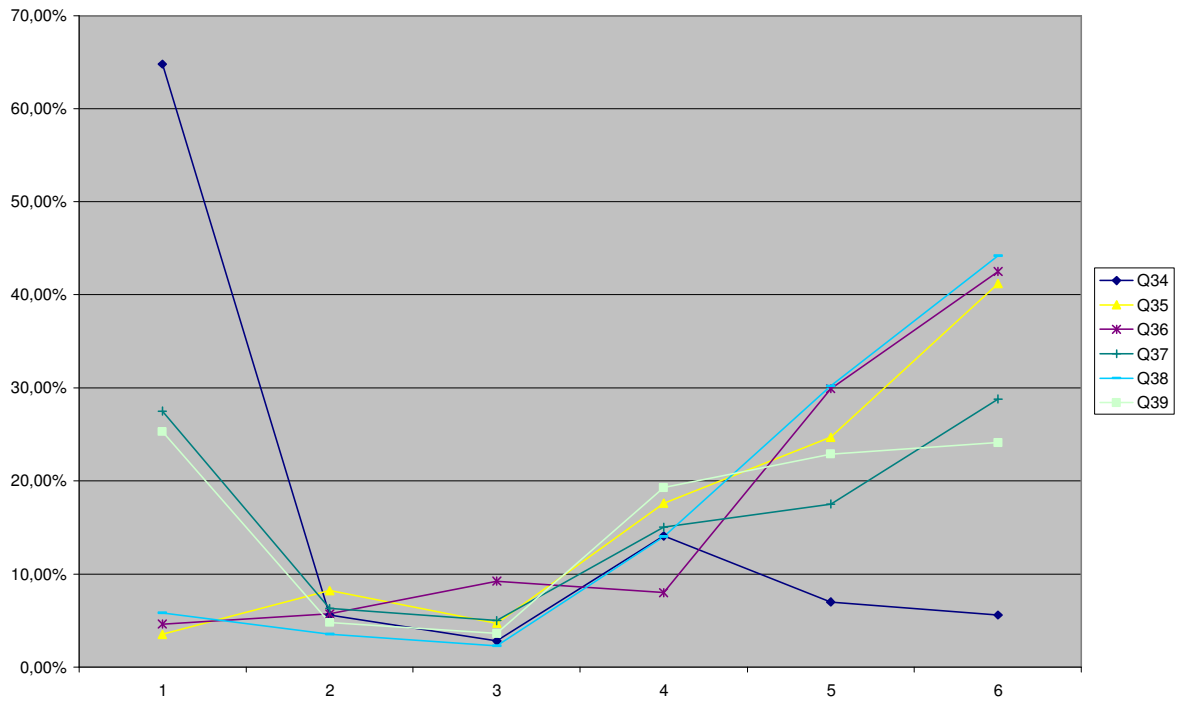

Gráfico 5.56 - Distribuição de Freqüência do Fator Crítico - Práticas e Valores

Olhando o fator crítico (Gráfico 5.56), Práticas e Valores, percebe-se, com os resultados, que as ações são vistas de forma positiva pelos professores, tendo sido observada a negligência apenas nas questões de saúde.

Tabela 5.13 - Medidas de posição e dispersão das variáveis integrantes do fator crítico Práticas e Valores

\begin{tabular}{|c|c|c|c|c|c|c|c|c|c|c|}
\hline & & 1 & 2 & 3 & 4 & 5 & 6 & Total & Média & $\begin{array}{l}\text { Desvio- } \\
\text { padrão }\end{array}$ \\
\hline \multirow[t]{2}{*}{ Q34 } & $\mathrm{N}$ & 46 & 4 & 2 & 10 & 5 & 4 & 71 & 2,0986 & 1,6746 \\
\hline & $\%$ & $64,8 \%$ & $5,6 \%$ & $2,8 \%$ & $14,1 \%$ & $7,0 \%$ & $5,6 \%$ & $100,0 \%$ & & \\
\hline \multirow[t]{2}{*}{ Q35 } & $\mathrm{N}$ & 3 & 7 & 4 & 15 & 21 & 35 & 85 & 4,7529 & 1,4302 \\
\hline & $\%$ & $3,5 \%$ & $8,2 \%$ & $4,7 \%$ & $17,6 \%$ & $24,7 \%$ & $41,2 \%$ & $100,0 \%$ & & \\
\hline \multirow[t]{2}{*}{ Q36 } & $\mathrm{N}$ & 4 & 5 & 8 & 7 & 26 & 37 & 87 & 4,8046 & 1,4535 \\
\hline & $\%$ & $4,6 \%$ & $5,7 \%$ & $9,2 \%$ & $8,0 \%$ & $29,9 \%$ & $42,5 \%$ & $100,0 \%$ & & \\
\hline \multirow[t]{2}{*}{ Q37 } & $\mathrm{N}$ & 22 & 5 & 4 & 12 & 14 & 23 & 80 & 3,7500 & 2,0220 \\
\hline & $\%$ & $27,5 \%$ & $6,3 \%$ & $5,0 \%$ & $15,0 \%$ & $17,5 \%$ & $28,8 \%$ & $100,0 \%$ & & \\
\hline \multirow[t]{2}{*}{ Q38 } & $\mathrm{N}$ & 5 & 3 & 2 & 12 & 26 & 38 & 86 & 4,9186 & 1,3909 \\
\hline & $\%$ & $5,8 \%$ & $3,5 \%$ & $2,3 \%$ & $14,0 \%$ & $30,2 \%$ & $44,2 \%$ & $100,0 \%$ & & \\
\hline \multirow[t]{2}{*}{ Q39 } & $\mathrm{N}$ & 21 & 4 & 3 & 16 & 19 & 20 & 83 & $\mid 3,8193$ & 1,9264 \\
\hline & $\%$ & $25,3 \%$ & $4,8 \%$ & $3,6 \%$ & $19,3 \%$ & $22,9 \%$ & $24,1 \%$ & $100,0 \%$ & & \\
\hline
\end{tabular}


Para desvendar se a instituição possui espaço para o desenvolvimento de uma Nova Competência, ou até mesmo se já possui, observa-se o resultado:

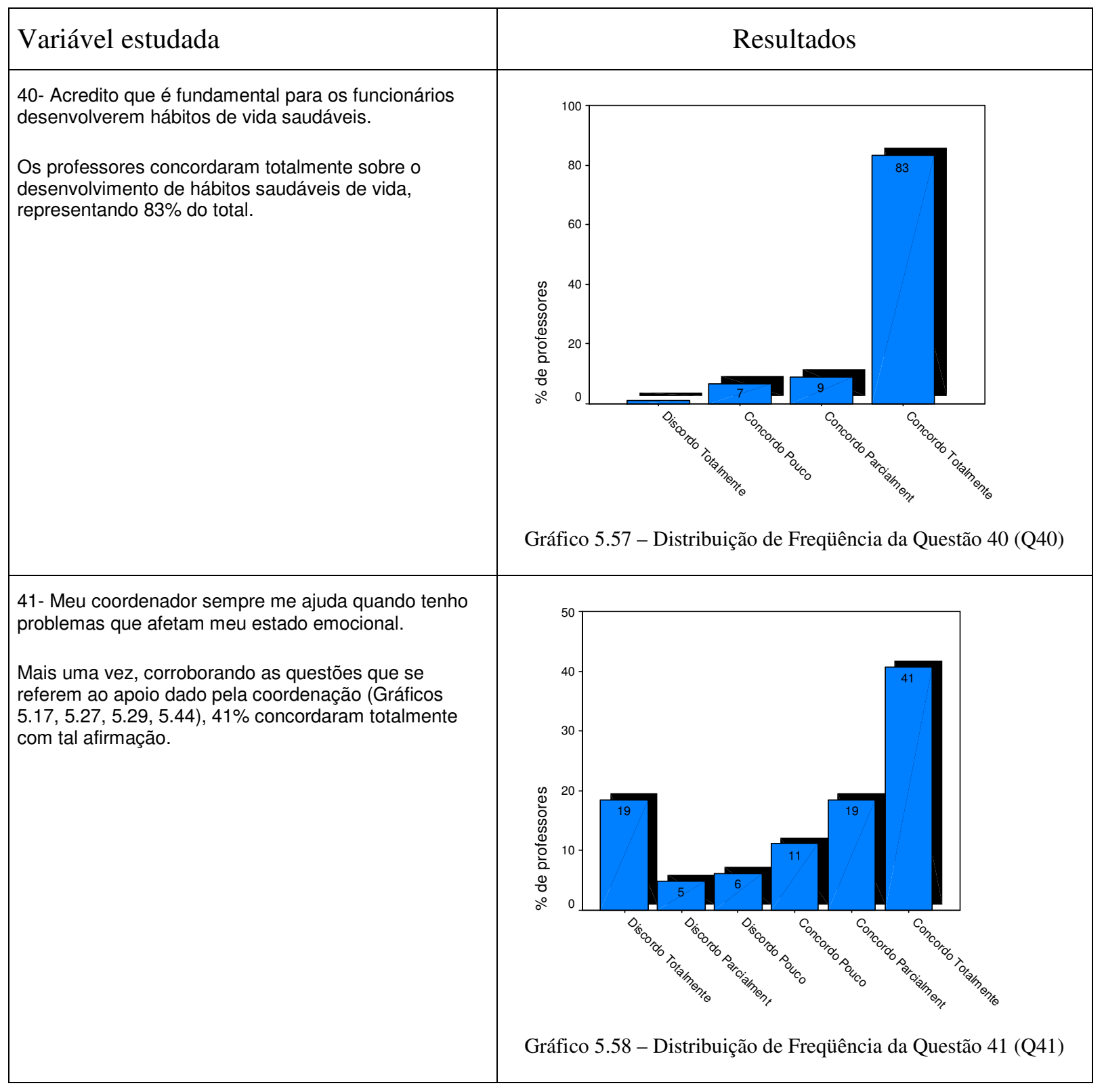




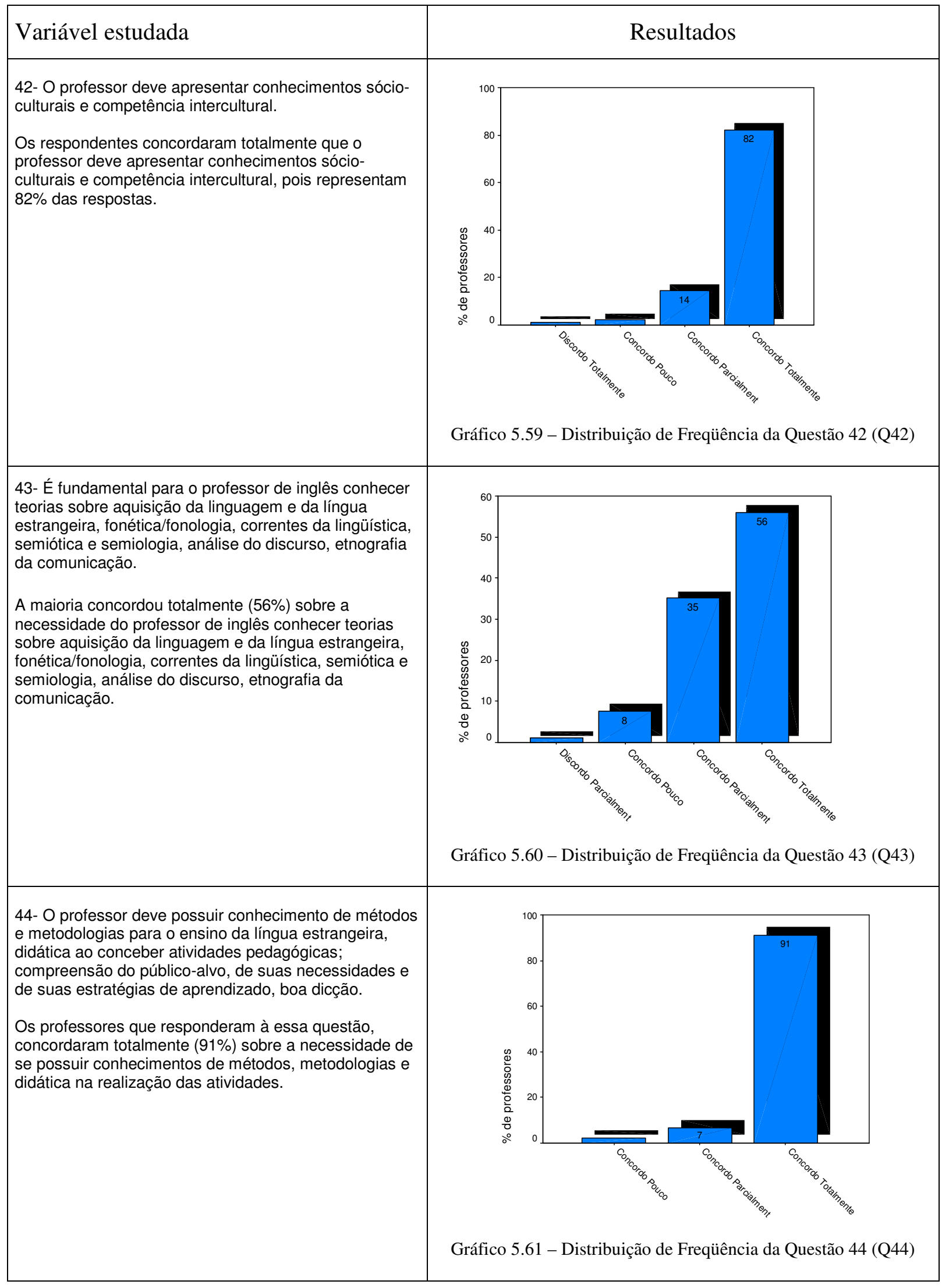



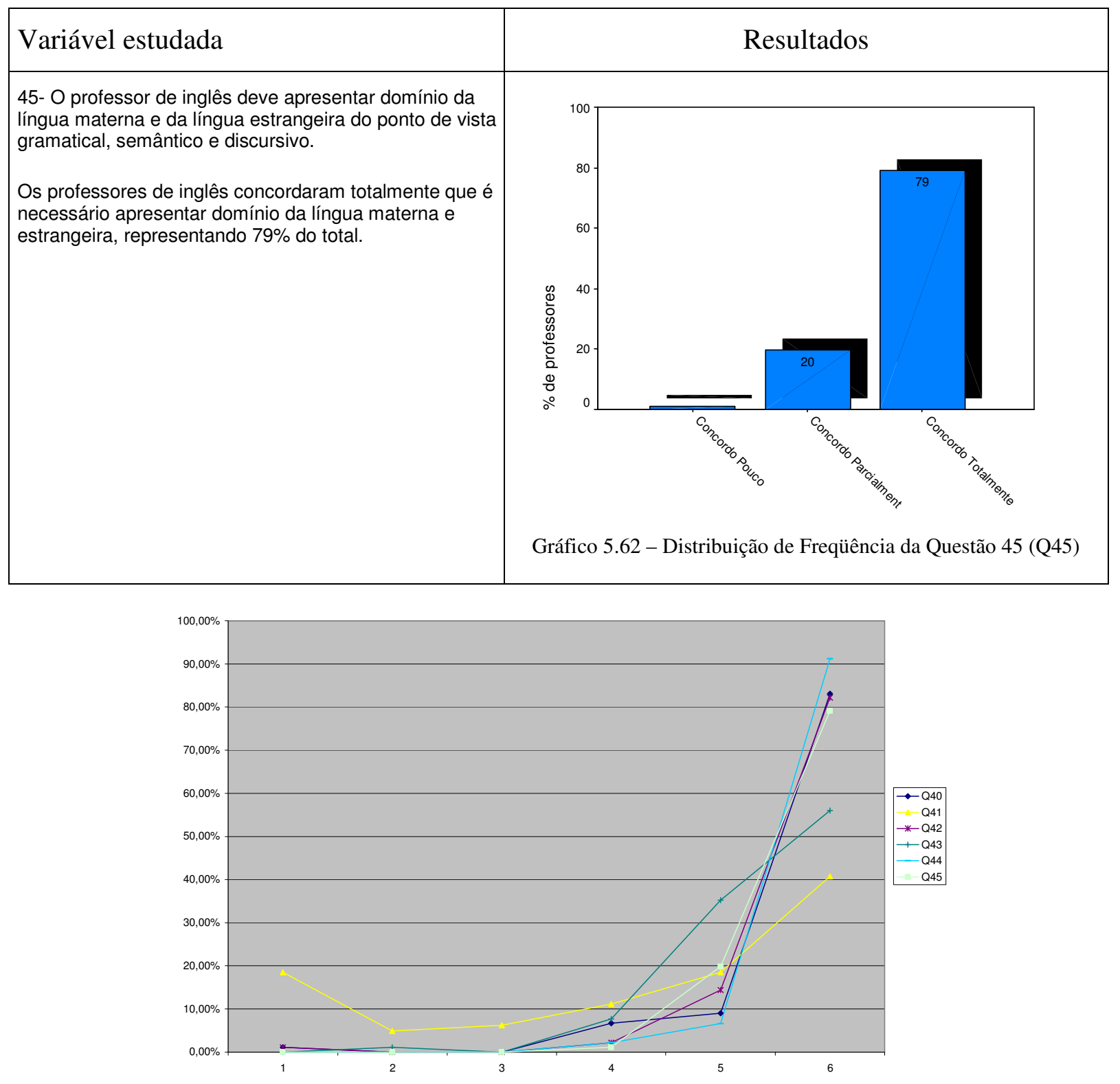

Gráfico 5.63 - Distribuição de Freqüência do Fator Crítico - Nova Competência

Com este resultado, nota-se que existe um grande espaço para o desenvolvimento de uma nova competência, pois todas as questões foram respondidas positivamente (Gráfico 5.63). 
Tabela 5.14 - Medidas de posição e dispersão das variáveis integrantes do fator crítico Nova Competência

\begin{tabular}{|l|l|r|c|c|r|r|r|r|r|r|}
\hline & & $\mathbf{1}$ & $\mathbf{2}$ & $\mathbf{4}$ & $\mathbf{5}$ & $\mathbf{6}$ & Total & Média & $\begin{array}{c}\text { Desvio- } \\
\text { padrão }\end{array}$ \\
\hline & & & & & & & & & & \\
\hline $\mathbf{Q 4 0}$ & $\mathrm{N}$ & 1 & & & 6 & 8 & 74 & 89 & 5,7191 & 0,7536 \\
\hline & $\%$ & $1,1 \%$ & & & $6,7 \%$ & $9,0 \%$ & $83,1 \%$ & $100,0 \%$ & & \\
\hline $\mathbf{Q 4 1}$ & $\mathrm{N}$ & 15 & 4 & 5 & 9 & 15 & 33 & 81 & 4,2840 & 1,9251 \\
\hline & $\%$ & $18,5 \%$ & $4,9 \%$ & $6,2 \%$ & $11,1 \%$ & $18,5 \%$ & $40,7 \%$ & $100,0 \%$ & & \\
\hline $\mathbf{Q 4 2}$ & $\mathrm{N}$ & 1 & & & 2 & 13 & 74 & 90 & 5,7556 & 0,6756 \\
\hline & $\%$ & $1,1 \%$ & & & $2,2 \%$ & $14,4 \%$ & $82,2 \%$ & $100,0 \%$ & & \\
\hline $\mathbf{Q 4 3}$ & $\mathrm{N}$ & & 1 & & 7 & 32 & 51 & 91 & 5,4505 & 0,7343 \\
\hline & $\%$ & & $1,1 \%$ & & $7,7 \%$ & $35,2 \%$ & $56,0 \%$ & $100,0 \%$ & & \\
\hline Q44 & $\mathrm{N}$ & & & & 2 & 6 & 83 & 91 & 5,8901 & 0,3786 \\
\hline & $\%$ & & & & $2,2 \%$ & $6,6 \%$ & $91,2 \%$ & $100,0 \%$ & & \\
\hline Q45 & $\mathrm{N}$ & & & & 1 & 18 & 72 & 91 & 5,7802 & 0,4423 \\
\hline & $\%$ & & & & $1,1 \%$ & $19,8 \%$ & $79,1 \%$ & $100,0 \%$ & & \\
\hline
\end{tabular}

Para a construção das tabelas 5.9 a 5.14 e os gráficos 5.21, 5.32, 5.42, 5.49, 5.56, 5.63, consolidados, as assertivas que possuíam conotação negativa, foram transformadas em afirmativas, de modo que fosse possível ilustrar os aspectos vistos com maior ou menor concordância.

Foram efetuados alguns testes para se tentar explicar as questões que resultaram em um desvio-padrão maior que 1,9 (Tabelas 5.9 a 5.14). Utilizando-se o coeficiente de Spearman, observou-se que (Quadros 5.3 e 5.4):

Q1 está associada ao tempo de profissão, idade, faixa salarial e horas trabalhadas, isto é:

1) quanto maior o tempo de profissão, mais se acredita que a quantidade de horas trabalhadas prejudica o estado geral de saúde (efeito cumulativo); 
2) à medida que vão adquirindo mais anos de vida, mais se acredita que a quantidade de horas trabalhadas prejudica o estado geral de saúde;

3) quanto maior o salário, mais se acredita que a quantidade de horas trabalhadas prejudica o estado geral de saúde;

4) quanto mais horas trabalhadas, mais se acredita que a quantidade de horas trabalhadas prejudica o estado geral de saúde.

Q3 está associada à idade, estado civil, faixa salarial e horas trabalhadas, isto é:

1) à medida que vão adquirindo mais anos, mais se concorda que as horas trabalhadas afetam as atividades dentro e fora da aula;

2) aqueles que são casados concordam mais que as horas trabalhadas afetam as atividades dentro e fora da aula;

3) quanto maior o salário, mais se concorda que as horas trabalhadas afetam as atividades dentro e fora de sala;

4) quanto mais horas trabalhadas, mais se concorda que as horas trabalhadas afetam as atividades dentro e fora de sala.

Q25 está associada ao tempo de profissão e à faixa salarial, isto é:

1) quanto mais tempo se trabalha na organização, mais chance de se participar de congressos, nacionais e/ou internacionais; 
2) quanto maior o salário, mais chance de se participar de congressos, nacionais e/ou internacionais.

Q31 está relacionada à faixa salarial, isto é:

1) quanto maior o salário, mais se concorda que recebem apoio para realizar trabalhos junto à comunidade.

Q33 está relacionada ao tempo de profissão e à idade, isto é:

1) quanto mais tempo na carreira, menos se concorda que se tem oportunidade de realizar outros cursos de idiomas;

2) à medida que vão adquirindo mais anos, menos se concorda que se tem a oportunidade de realizar outros cursos de idiomas.

Q37 está relacionada ao tempo de profissão e à faixa salarial, isto é:

1) quanto mais tempo na carreira, mais se acredita que a empresa participa de programas voltados à cidadania;

2) quanto maior o salário, mais se acredita que a empresa participa de programas voltados à cidadania.

Q39 está relacionada ao número de dependentes e à faixa salarial, isto é:

1) quanto mais dependentes, mais se acredita que a instituição prepara para lidar com a evolução tecnológica; 
2) quanto maior o salário, mais se acredita que a instituição prepara para lidar com a evolução tecnológica.

Q5, Q10, Q12, Q15 Q20 e Q41 não estiveram associadas a nenhuma variável.

Para a construção dos quadros 5.3, 5.4, 5.5 e 5.6 utilizou-se a função Analyse, Correlate, Bivariate Correlations, Spearman do SPSS.

Quadro 5.3 - Análise das associações e correlação de postos, utilizando o coeficiente Spearman

\begin{tabular}{|c|c|c|c|c|c|c|c|c|c|}
\hline & $\begin{array}{c}\text { 46- } \\
\text { Tempo } \\
\text { de } \\
\text { profissão }\end{array}$ & $\begin{array}{l}\text { 47- } \\
\text { Idade }\end{array}$ & $\begin{array}{l}\text { 48- } \\
\text { Sexo }\end{array}$ & $\begin{array}{c}\text { 49- } \\
\text { No.depen- } \\
\text { dentes }\end{array}$ & $\begin{array}{l}50- \\
\text { Estad } \\
\text { o civil }\end{array}$ & $\begin{array}{c}\text { 51-Faixa } \\
\text { salarial }\end{array}$ & $\begin{array}{c}\text { 57- } \\
\text { Regime } \\
\text { de } \\
\text { trabalho }\end{array}$ & $\begin{array}{c}58- \\
\text { Escolari- } \\
\text { dade }\end{array}$ & Hs Trab. \\
\hline Q1 & $0,286^{\star *}$ & $0,266^{*}$ & $-0,062$ & 0,176 & $-0,097$ & $0,286^{\star \star}$ & $-0,132$ & 0,209 & $0,441^{\star *}$ \\
\hline Q3 & 0,190 & $0,239^{\star}$ & $-0,127$ & 0,192 & $-0,231^{*}$ & $0,214^{\star}$ & $-0,018$ & 0,168 & $0,286^{* *}$ \\
\hline Q5 & 0,162 & 0,178 & $-0,147$ & 0,153 & 0,021 & $-0,004$ & $-0,049$ & 0,209 & $-0,035$ \\
\hline Q10 & $-0,013$ & $-0,009$ & $-0,053$ & 0,113 & $-0,083$ & $-0,174$ & $-0,015$ & $-0,046$ & $-0,140$ \\
\hline Q12 & 0,099 & 0,139 & $-0,011$ & $-0,003$ & $-0,047$ & 0,064 & 0,147 & 0,168 & 0,079 \\
\hline Q15 & $-0,123$ & $-0,067$ & 0,116 & $-0,111$ & 0,048 & $-0,119$ & $-0,024$ & $-0,086$ & 0,014 \\
\hline Q20 & $-0,020$ & $-0,023$ & $-0,176$ & 0,096 & 0,007 & $-0,040$ & $-0,067$ & $-0,073$ & $-0,055$ \\
\hline Q25 & $0,320^{* *}$ & 0,199 & 0,017 & 0,191 & $-0,153$ & $0,325^{\star \star}$ & 0,032 & 0,055 & 0,189 \\
\hline Q31 & 0,126 & 0,103 & 0,075 & 0,166 & $-0,059$ & $0,297^{\star}$ & 0,009 & $-0,072$ & 0,159 \\
\hline Q33 & $-0,238^{\star}$ & $-0,236^{*}$ & 0,044 & $-0,082$ & $-0,003$ & $-0,040$ & $-0,146$ & $-0,165$ & $-0,223$ \\
\hline Q37 & $0,323^{\star \star}$ & 0,209 & $-0,038$ & 0,190 & $-0,089$ & $0,300^{\star \star}$ & 0,066 & 0,105 & 0,136 \\
\hline Q39 & 0,173 & 0,166 & 0,062 & $0,268^{\star}$ & $-0,187$ & $0,260^{*}$ & $-0,197$ & 0,055 & 0,165 \\
\hline Q41 & $-0,046$ & 0,016 & 0,025 & 0,011 & $-0,004$ & 0,041 & $-0,029$ & $-0,037$ & 0,023 \\
\hline
\end{tabular}

**Correlação é significante no nível de .01

*Correlação é significante no nível de .05 
Quadro 5.4 - Nível descritivo do coeficiente de Spearman entre as questões

\begin{tabular}{|l|c|c|c|c|c|c|c|c|c|}
\hline & $\begin{array}{c}\text { 46-Tempo } \\
\text { de } \\
\text { profissão }\end{array}$ & 47-Idade & $\begin{array}{c}\text { 48- } \\
\text { Sexo }\end{array}$ & $\begin{array}{c}\text { 49- } \\
\text { No.depen- } \\
\text { dentes }\end{array}$ & $\begin{array}{c}\text { 50- } \\
\text { Estado } \\
\text { civil }\end{array}$ & $\begin{array}{c}\text { 51-Faixa } \\
\text { salarial }\end{array}$ & $\begin{array}{c}\text { 57- } \\
\text { Regime } \\
\text { de } \\
\text { trabalho }\end{array}$ & $\begin{array}{c}\text { 58- } \\
\text { Escolari } \\
\text { dade }\end{array}$ & Hs.Trab. \\
\hline Q1 & 0,007 & 0,013 & 0,569 & 0,103 & 0,369 & 0,007 & 0,241 & 0,052 & 0,000 \\
\hline Q3 & 0,076 & 0,024 & 0,235 & 0,71 & 0,030 & 0,044 & 0,871 & 0,117 & 0,009 \\
\hline Q5 & 0,135 & 0,099 & 0,174 & 0,158 & 0,847 & 0,971 & 0,667 & 0,052 & 0,752 \\
\hline Q10 & 0,901 & 0,930 & 0,623 & 0,293 & 0,440 & 0,104 & 0,890 & 0,669 & 0,208 \\
\hline Q12 & 0,408 & 0,241 & 0,924 & 0,980 & 0,691 & 0,591 & 0,232 & 0,156 & 0,519 \\
\hline Q15 & 0,255 & 0,533 & 0,283 & 0,303 & 0,660 & 0,271 & 0,830 & 0,424 & 0,903 \\
\hline Q20 & 0,877 & 0,859 & 0,174 & 0,461 & 0,956 & 0,762 & 0,622 & 0,575 & 0,686 \\
\hline Q25 & 0,003 & 0,068 & 0,878 & 0,079 & 0,163 & 0,002 & 0,781 & 0,616 & 0,093 \\
\hline Q31 & 0,320 & 0,416 & 0,555 & 0,187 & 0,641 & 0,016 & 0,948 & 0,569 & 0,218 \\
\hline Q33 & 0,032 & 0,033 & 0,696 & 0,466 & 0,978 & 0,719 & 0,208 & 0,139 & 0,053 \\
\hline Q37 & 0,004 & 0,062 & 0,738 & 0,092 & 0,434 & 0,007 & 0,574 & 0,353 & 0,246 \\
\hline Q39 & 0,120 & 0,133 & 0,580 & 0,014 & 0,090 & 0,018 & 0,086 & 0,619 & 0,151 \\
\hline Q41 & 0,684 & 0,890 & 0,825 & 0,920 & 0,975 & 0,716 & 0,803 & 0,742 & 0,843 \\
\hline
\end{tabular}

Encontrou-se associação da faixa salarial com as seguintes variáveis (Quadro 5.5 e 5.6):

1) Tempo de profissão: quanto maior o tempo na carreira, maior o salário;

2) Quantidade de horas trabalhadas: quanto mais horas trabalhadas, maior o salário;

3) Escolaridade: quanto maior a escolaridade, maior o salário.

Quadro 5.5 - Análise das associações e correlação de postos, utilizando o coeficiente Spearman

\begin{tabular}{|l|l|}
\hline \multicolumn{1}{|c|}{ Variáveis } & Faixa Salarial \\
\hline Tempo de profissão & $0,707^{* *}$ \\
\hline Quantidade de horas trabalhadas & $0,477^{\star *}$ \\
\hline Escolaridade & $0,501^{* *}$ \\
\hline Outra ocupação além de professor & 0,045 \\
\hline
\end{tabular}


Quadro 5.6 - Nível descritivo do coeficiente de Spearman entre as questões

\begin{tabular}{|l|l|}
\hline \multicolumn{1}{|c|}{ Variáveis } & Faixa Salarial \\
\hline Tempo de profissão & 0,000 \\
\hline Quantidade de horas trabalhadas & 0,000 \\
\hline Escolaridade & 0,000 \\
\hline Outra ocupação além de professor & 0,679 \\
\hline
\end{tabular}




\section{Capítulo 6 - Conclusões}

A partir da análise dos resultados apresentados, é possível tecer algumas considerações sobre este estudo. Tendo em vista o objetivo exposto inicialmente, o de identificar as percepções de QVT dos professores de inglês utilizando-se o modelo de competências para a GQVT e a abordagem BPSO-96, concluiu-se que:

a) Fator crítico - conceito de QVT: é negligenciado nos aspectos da saúde e carreira. Dentro dos conceitos apresentados por Lippitt e Camacho (apud Limongi-França, 1996) vê-se que a QVT precisa ser pensada no contexto do crescimento no trabalho de modo que exista uma perspectiva de futuro, sendo tudo isso apoiado pela sobrevivência com dignidade. Os professores pesquisados se preocupam bastante com a questão salarial, e há indícios de que quanto mais se trabalha, maiores são os ganhos financeiros, ao passo que as horas trabalhadas afetam a saúde. Dantas (apud Limongi-França, 1996) dá destaque para as questões de promoção da saúde, enfatizando que se a empresa olhar para este aspecto, caminha em direção à QVT.

Percebe-se que todos os aspectos estão relacionados quando não existe a gestão de carreira (Dutra, 2001), todo o processo é afetado, trazendo maiores conseqüências para a saúde. Sem o planejamento de carreira, os professores trabalham o máximo de horas que podem para aumentar seus ganhos no final do mês, que por sua vez, trazem danos à saúde por excesso de trabalho. As horas em excesso podem provocar os problemas vocais mencionados por Roy et al. (2004), as lesões por esforços repetitivos (LER) devido à realização de movimentos repetitivos na execução das tarefas, com a utilização de quadro negro, giz e apagador. Além disso, o uso de agentes químicos, como exemplo o giz, pode acarretar em uma doença profissional (Mendes, 1995). 
b) Fator crítico - Produtividade: para Drucker (2000), além de conhecer a tarefa que será realizada, um dos determinantes da relação de produtividade do trabalhador do conhecimento, está no aprendizado e ensino contínuos e na importância do professor querer trabalhar para a organização. Nesse ponto, percebe-se que os professores de inglês desse estudo se identificam muito com a organização, gostam de trabalhar nela, estão integrados a ela, porém, dá-se pouca ênfase à gestão da carreira, pois não são apoiados a participar de eventos culturais, congressos e cursos externos. Os resultados da pesquisa mostraram que as instituições têm contratado professores que são ex-alunos, reforçando a idéia da identidade.

A própria questão da saúde mencionada anteriormente é um aspecto também identificado como falho nas questões de produtividade. Com todos os problemas que podem ocorrer, o índice de absenteísmo pode crescer, comprometendo a produtividade e conseqüentemente, a organização como um todo.

c) Fator crítico - Legitimidade: sendo a legitimidade entendida como algo que é aceito pela maioria (Houaiss et al., 2004), cabe destacar a questão do orgulho que os professores e seus familiares sentem por atuarem nesta profissão em tais instituições. De acordo com Berger \& Luckman (1978), a legitimidade traz o conceito de uma tradição teórica, ou seja, a atividade do professor ainda é vista como uma atividade de caráter aristocrático (Sady, 1996), embora não o apresente mais.

Além do orgulho dos professores e familiares, pode-se dizer que os alunos também legitimam tais instituições, pois de acordo com o Gráfico 5.7 e a Tabela 5.4, são essas instituições que têm formado os professores de inglês. 
Conforme encontrado nas questões anteriores, a saúde e carreira não são percebidas como legítimas pelos pesquisados.

É pertinente mencionar a metáfora de Morgan (1996), que neste estudo não se percebe claramente, pois ao atuarem como professores de inglês, tais respondentes não parecem ser prisioneiros do sucesso nem tampouco da acomodação organizacional. Os resultados indicam que os professores da amostra gostam do que fazem, estando nessa ocupação por uma questão de valores e princípios.

d) Fator crítico - Perfil do Gestor: considerando o papel dos coordenadores e/ou diretores, na qualidade de gestores mencionada pelo MEC apud Limongi-França (2003), as organizações pesquisadas promovem a comunicação interpessoal, atendendo aos interesses interpessoais e institucionais, porém não atuam de modo integrado, sistêmico e estratégico, nem são capazes de lidar com modelos de gestão inovadores, que privilegiam, por exemplo, a relação com o ambiente externo, pois em se tratando das questões relacionadas à comunidade, bem como as ações de cidadania, percebe-se uma lacuna, que na visão de Drucker (1991) é papel dos gestores dirigirem suas instituições olhando para a sociedade, pois os problemas sociais são disfunções da sociedade e não impactos da organização e de suas atividades. O professor, sendo um facilitador no processo de aprendizagem, acaba por conseguir aquilo que Rosa Fischer (2002) destaca sobre o desafio da gestão de pessoas quanto a favorecer as condições e os recursos para que se desenvolva uma cultura de cidadania organizacional.

Além da questão social, o estudo mostrou que os coordenadores e diretores de unidade são falhos ao atentar para a gestão de carreira dos seus subordinados, pois é função daqueles 
selecionar estratégias adequadas de ação, visando atender interesses interpessoais e institucionais, através de procedimentos que busquem formas de atuação em direção aos objetivos comuns (MEC apud Limongi-França, 2003). Vê-se, neste caso, a necessidade de se pensar a organização de forma estratégica, conforme Albuquerque (2002) lista resultados que podem ser obtidos a longo prazo quando as estratégias são adotadas e seguidas.

e) Fator crítico - Práticas e Valores: embora não se tenha percebido um programa formal de GQVT, fato este que ocorre em muitas empresas (Limongi-França, 1996), os professores de inglês percebem que algumas práticas organizacionais geram resultados positivos, como a avaliação de desempenho, que mostra resultados positivos quando as escolas a realizam. Outra prática positiva é o recrutamento e seleção, pois os professores pesquisados percebem que os instrumentos utilizados são adequados. Tais práticas deveriam fazer parte de um plano estratégico, pois ao defini-las, as organizações podem focar o resultado desejado dos empregados (Wright et al., 2001).

Mais uma vez, foi mencionada a questão da saúde, que não é uma prática adotada nas instituições onde os pesquisados atuam.

f) Fator crítico - Nova competência: os resultados mostram que é claro o espaço existente para o desenvolvimento de uma nova competência, pois os respondentes da pesquisa concordaram que o professor de inglês precisa apresentar as competências propostas por Ferreira (1998): conhecimentos teóricos, competências lingüísticas, conhecimentos e competências pedagógico-didáticos, conhecimentos técnicos, conhecimentos sócio-culturais e competência intercultural. É através delas que se consegue o que Fleury (2001) define sobre competências individuais, e mais que isso, quando existe a formulação da estratégia e a 
formação de competências, cria-se um círculo que se retro-alimenta (Fleury \& Lacombe, 2003).

Essa pesquisa também procurou encontrar alguns objetivos mais específicos: identificar se os indicadores de QVT guardam alguma relação com a condição sócioeconômica; as possíveis explicações para as semelhanças ou diferenças nas percepções; e os aspectos mais evidentes na abordagem BPSO-96.

Salientando que os indicadores de QVT referem-se às questões que compõem a pesquisa, onde apenas algumas delas foram estudadas isoladamente. Com isso, pode-se concluir, a respeito dessas questões, que:

a) As condições físicas estão associadas ao tempo de profissão, idade, faixa salarial e horas trabalhadas. Com o tempo, os professores percebem que o excesso de trabalho impacta negativamente em sua saúde, embora mais trabalho represente também uma maior remuneração. Esse resultado demonstra que a ausência de um plano de gestão de carreira impacta em danos à saúde.

b) As condições psicológicas estão associadas à idade, estado civil, faixa salarial e horas trabalhadas. Com o tempo, os professores percebem que o excesso de trabalho impacta negativamente em sua condição psicológica, assim como destacou o SINPROSP (2004), ao descrever que um dos principais problemas dos professores era ter que levar trabalho para casa, afetando as questões pessoais. Na mesma linha do que foi mencionado no item a, mais trabalho é necessário, pois eleva-se a fonte de renda. Mais uma vez, a ausência de um plano de gestão de carreira impacta na saúde psicológica. 
c) As condições sociais, que neste estudo enfatizam a oportunidade de participar de congressos nacionais e/ou internacionais, estão associadas ao tempo de profissão e à faixa salarial. Evidencia que o profissional que desenvolve uma carreira nessa profissão tem maiores chances de se aperfeiçoar através desses congressos, além de receber uma maior remuneração.

Outro aspecto social é o apoio recebido para a realização de trabalhos junto à comunidade, que está relacionado ao salário. Levanta-se a hipótese de que os professores que possuem uma remuneração mais elevada fazem parte de organizações mais bem estruturadas, possuidoras de políticas de gestão definidas dentro de um modelo que leva em consideração fatores como tecnologia, estratégia de organização do trabalho, cultura organizacional, estrutura organizacional e os fatores externos (Fischer, A., 2002).

d) As condições da organização estão relacionadas ao tempo de profissão, à idade e à remuneração. Essa associação corrobora todos os itens anteriores que se referiram à ausência de gestão de carreira, pois os resultados obtidos sinalizam que quanto mais tempo na carreira, menos se concorda que se tem oportunidade de realizar outros cursos de idiomas, e à medida que vão adquirindo mais anos de trabalho na escola, menos se concorda que se tem a oportunidade de realizar outros cursos de idiomas. O tempo de atuação na profissão gera a certeza ao professor de inglês de que as instituições não deverão investir em seu desenvolvimento pessoal, pois de acordo com o que foi visto na literatura, qualquer tipo de desenvolvimento proporcionado ao professor visa melhorar seu desempenho em sala de aula (Leffa, 2001; Guimarães, 2004). Contrário ao que foi salientado por Gorz (2004), as instituições de ensino são vistas como empresas e os alunos tratados como clientes, situação 
esta que reforça o discurso publicitário proferido pelas escolas de idiomas (Carmagnani, 2001).

Quanto ao salário, nota-se que, da mesma forma que a questão da cidadania, ele influencia na percepção dos respondentes quanto ao apoio dado à inovação tecnológica. Imagina-se que os respondentes, com uma remuneração relativamente mais alta em relação à média, trabalhem em instituições com políticas de gestão mais estruturadas, o que por sua vez possibilitaria o pagamento de melhores salários.

As possíveis explicações para as semelhanças ou diferenças nas percepções, residem no tempo de profissão, na quantidade de horas trabalhadas e na escolaridade. Já havia sido mencionado que o tempo de profissão aumenta a remuneração, assim como as horas trabalhadas. Mas não havia sido abordada a questão da escolaridade. Encontrou-se uma associação entre a escolaridade e o salário recebido, ou seja, quanto maior a escolaridade, maior a remuneração, embora os resultados da pesquisa descrevam uma amostra cuja escolaridade é em grande parte composta de pessoas que informaram possuir superior incompleto (Gráfico 5.3).

As considerações deste capítulo refletem a necessidade que as organizações têm em possuir estratégias bem definidas, pois a gestão de pessoas é prejudicada quando isso não ocorre, trazendo conseqüências no longo prazo por ações que são tomadas no curto prazo. 


\subsection{Contribuições do Estudo}

O estudo pretendia levantar alguns insights sobre a QVT dos professores de inglês, trazendo algumas contribuições que merecem ser destacadas. Observou-se duas formas de contribuição:

a) acadêmicas:

Criar o espaço para a discussão do tema neste ambiente organizacional;

Maior conhecimento do profissional em estudo.

b) aos beneficiários da pesquisa, que serão listadas em forma de sugestões:

1) os professores: beneficiários diretos, pois participaram ativamente do resultado obtido.

O próprio SINPROSP (2004) sugere que o professor previna-se, buscando orientações junto aos profissionais relacionados à área (fonoaudiólogo e médico otorrinolaringologista), e verifiquem as condições de sua voz;

A busca de maior escolaridade se quiser trilhar uma carreira nessa área, pois a pesquisa indicou que o salário guarda uma relação direta com o nível educacional;

Qualificar-se em áreas relacionadas ao ensino de inglês e gestão de empresas, dentro das competências definidas por Ferreira (1998) e do perfil do gestor (MEC apud Limongi-França, 2003), pois isso pode amenizar os resultados evidenciados nessa pesquisa sobre o despreparo dos professores de inglês em gerir uma organização quando passam às posições de coordenadores ou diretores de unidades. 
2) os coordenadores:

Qualificar-se em áreas relacionadas à gestão de empresas dentro do perfil do gestor (MEC apud Limongi-França, 2003), pois isso pode amenizar os resultados evidenciados nessa pesquisa sobre o despreparo dos coordenadores para gerir uma empresa. De acordo com Limongi-França (1996), o conceito de GQVT só é integralmente compreendido se o conjunto das ações de uma empresa envolver a implantação de melhorias e inovações gerenciais, tecnológicas e estruturais do ambiente de trabalho, questões como saúde e carreira que neste estudo mostraramse falhas, e são de responsabilidade dos gestores;

Atentar para a necessidade de se estabelecer um plano de carreira para os professores, envolvendo mais as questões de seu desenvolvimento pessoal e intelectual, ainda que tudo isso não represente a mudança de cargo.

3) as instituições:

Voltar-se para sua missão e criar políticas que estejam direcionadas ao cumprimento desta missão, ou seja, pensar na organização de forma estratégica (Albuquerque, 2002);

Contribuir para o aprimoramento na formação dos professores e coordenadores, como cidadãos e profissionais, para que colaborem na elevação das condições de vida em sociedade (MEC apud Limongi-França, 2003);

Entender as questões de saúde como fundamentais para garantir a competitividade da instituição; 
Primar pela qualidade no ensino através de um corpo de professores e coordenadores preparados técnica e culturalmente;

Valorizar os professores que estejam cursando áreas afins ou já sejam formados nessas áreas, pois acredita-se que com o desenvolvimento dessa nova competência, as questões de QVT podem se elevar;

Tentar pensar a longo prazo, de modo a apoiar programas de desenvolvimento e carreira dos profissionais em questão. Os professores dessa amostra encontram-se no estágio da estabilização, concentrando sua idade na faixa dos 25 aos 44 anos (Gráfico 5.1), representando um momento em que há a concentração de esforços para permanecer na área, tida como a desejada (Super \& Bohn, 1972). Isto mostra coerência para que a organização estabeleça um plano de carreira.

4) os alunos:

Privilegiar as escolas que valorizam seus funcionários nos aspectos BPSO-96;

Primar pelo ensino de qualidade, entendendo que o aluno não pode ser visto como cliente (Gorz, 2004).

\subsection{Limitações do Estudo}

Por se tratar de um estudo exploratório, com a investigação de idéias e intuições, que para serem alcançadas foram submetidas a uma revisão bibliográfica e pesquisa que podem não ter contemplado todos os aspectos relacionados ao objeto de pesquisa. Dessa forma, as limitações do estudo são listadas a seguir: 
Poucos estudos sobre os profissionais em questão;

Falta de visão de negócios das escolas de inglês, dificultando o acesso à pesquisa;

Dificuldade na obtenção de dados estatísticos que pudessem comprovar fatos da realidade (ex.: rotatividade, número total de professores no Brasil);

Informações estão dispersas.

\subsection{Proposição para novos estudos}

Quando se chega ao final de um estudo, percebe-se quantas respostas ainda estão por ser desvendadas. Mais que isso, o próprio resultado estimula novas descobertas, por isso, cabe destacar algumas delas:

Aprofundar mais o estudo sobre as Relações de Trabalho existentes entre as escolas de inglês e os professores, visando sustentar o que foi mencionado pelo SINPROSP (2004) quanto aos critérios de remuneração pertinentes à profissão e o que Sady (1996) define sobre a contratação de professores como profissionais autônomos;

> Identificar o sentido do trabalho para esses profissionais;

Identificar aspectos que poderiam tornar a carreira mais valorizada;

Investigar por onde passam os valores e princípios dos professores de inglês, ou seja, qual é a âncora de carreira descrita por Schein (1993) que move suas vidas: Competência Técnica/Funcional, Competência para Gerência Geral, Autonomia/Independência, Segurança/Estabilidade, Criatividade Empreendedora, Serviço/Dedicação a uma Causa, Desafio Puro ou Estilo de Vida; 
Testar o modelo conceitual utilizado como referência, visto que o mesmo é complexo e uma vez testado, poderia trazer contribuições e avanços neste campo organizacional quanto à GQVT;

> Pesquisar o lado da empresa, através de estudos em instituições isoladas;

Confrontar as respostas obtidas à análise das coordenações, de modo que elas possam afirmar as percepções dos professores ou negá-las;

Conhecer as razões porque os alunos escolhem um determinado curso e não outro;

Realizar um estudo cujo foco seja a gestão de carreira desses profissionais;

Identificar como são tomadas as decisões no nível gerencial, visando identificar a existência de uma formulação estratégica. 
Bibliografia Consultada

ALBERTO, L. C. F. R. Os determinantes da felicidade no trabalho: um estudo sobre a diversidade nas trajetórias profissionais de engenheiros. São Paulo, 2000. 123 p. Dissertação (Mestrado em Psicologia) - IP/USP, São Paulo.

ALBUQUERQUE, L. G. A gestão estratégica de pessoas. In: FLEURY, M.T.L. (Org.) As pessoas na organização. São Paulo: Gente, 2002.

ALVES, M.B.M.A.; ARRUDA, S. M. Como fazer referências (bibliográficas, eletrônicas e demais formas de documentos). Disponível em: $<$ http://bu.ufsc.br/framerefer.html $>$. Acesso em: 26 nov. 2004.

ANDRADE, L. M. V. Qualidade de vida no trabalho: um estudo descritivo entre os servidores da Universidade Federal de Lavras (UFLA). Lavras, 1997. 130 p. Dissertação (Mestrado em Administração) - UFLA, Minas Gerais.

ANDRADE, M. M. T. Inovação em uma rede de franchising: estudo do caso Yázigi. São Paulo, 1993. 198 p. Dissertação (Mestrado em Administração) FEA/USP, São Paulo.

ARELLANO, E. B. Qualidade de vida no trabalho: como a nutrição está inserida nos programas de QVT. São Paulo, 2003. 145 p. Dissertação (Mestrado em Administração) - FEA/USP, São Paulo.

ASSÉDIO MORAL. Disponível em: <www.assediomoral.org>. Acesso em: 22 out. 2004.

ASSOCIAÇÃO BRASILEIRA DE FRANCHISING (ABF). Disponível em: <http://www.portaldofranchising.com.br>. Acesso em: 12 mai. 2005.

ASTLEY, W.G., VAN DE VEN, A. H. Central perspectives and debates in organization theory. Administrative Science Quarterly, 28: 245-273, 1983.

BARNEY, J. Looking inside for competitive advantage. Academy of Management Executive, 9(4): 49-61, 1995.

BARRETO, M. Uma Jornada de Humilhações. São Paulo, 2000. 266 p. Dissertação (Mestrado em Psicologia) - Psicologia Social/PUC, São Paulo.

BENAVIDES, S. S. Qualidade de vida no trabalho e a gestão estratégica de recursos humanos: o projeto "vivendo bem" da Van Den Bergh. São Paulo, 2000. 121 p. Dissertação (Mestrado em Administração) - FEA/USP, São Paulo. 
BERGER, P.I.; LUCKMANN, T. A Construção Social da Realidade. Petrópolis: Editora Vozes, 1978.

BERLITZ International, Inc. Disponível em: $<$ http://www.berlitz.com.br/Employment/default.htm?ISO=pt $>$. Acesso em: 11 mai. 2005.

BORGES, R. S. G. Investigando as relações entre políticas de recursos humanos e os construtos comprometimento e qualidade de vida no trabalho. Belo Horizonte, 2005. 146 p. Dissertação (Mestrado em Administração) CEPEAD/UFMG, Minas Gerais.

BRIGHENTI, G. C.; SILVA, A. B.; FERNANDES, C. B. Qualidade de vida no trabalho: um estudo dos fatores e dimensões presentes e percebidas na central de relacionamento com os clientes da TIM celular de Santa Catarina. In: ENANPAD, 26. Anais...Bahia: ANPAD, 2002.

BUSSAB, W. O.; MORETTIN, P. A. Estatística básica. São Paulo: Atual, 1987.

CANÇADO, V. L.; LOPES, D. M. Trabalho e Saúde: um Estudo sobre Ginástica Laboral na Unilever. In: ENANPAD, 27. Anais...Atibaia/SP: ANPAD, 2003.

CAPES. Programas Reconhecidos. Disponível em http://www.capes.gov.br/capes/portal/. Acesso em: 10 abr. 05.

CARANDINA, D. M. Qualidade de vida no trabalho: construção e validação de um instrumento de medida para enfermeiras. São Paulo, 2003. 263 p.Tese (Doutorado em Enfermagem) - EE/USP.

CARICARI, A. M. As condições de vida e de trabalho dos trabalhadores da indústria da construção civil, na perspectiva da promoção da saúde: o caso de Bertioga. São Paulo, 2004. 147 p. Dissertação (Mestrado) - Saúde Pública/USP, São Paulo.

CARMAGNANI, A. M. G. As escolas de línguas e o discurso publicitário: construindo o desejo da língua estrangeira. In: CARMAGNANI, A. M. G. (org.) Inglês como língua estrangeira: identidade, práticas e textualidade. São Paulo: Humanitas, 2001.

CARVALHO, M. B. O trabalho de enfermagem psiquiátrica e os problemas de saúde dos trabalhadores. São Paulo, 2004. 215 p. Dissertação (Mestrado) EE/USP, São Paulo.

CCAA. Disponível em < www.ccaa.com.br> . Acesso em: 12 mai. 2005. 
CEL-LEP. Disponível em <www.cellep.com>. Acesso em 11 mai. 2005.

CHAUÍ, M. Convite à Filosofia. Editora Ática: São Paulo, 2004.

CNA Metodologia. Disponível em <http://www.cna.com.br $>$. Acesso em: 04 jan. 2003.

COELHO, J. A. Organizações e carreiras sem fronteiras: a percepção dos formandos sobre a tendência nas exigências profissionais. São Paulo, 2000. 98 p. Dissertação (Mestrado) - IP/USP.

COLIINS, J.C., PORRAS, J.I. Feitas para durar: práticas bem-sucedidas de empresas visionárias. Trad. Silvia Schiros. Rio de Janeiro: Rocco, 1995.

COSTA, I. F.; LIMONGI-FRANÇA, A. C. Qualidade de vida no trabalho: o estudo qualitativo na empresa Natura. In: SEMEAD, 5. Anais...São Paulo, 2001.

CUNHA, K. C. Gestão da qualidade de vida no trabalho em hospitais da cidade de São Paulo. São Paulo, 2004. 247 p. Tese (Pós-doutorado) - FEA/USP.

DETONI, D. J. Estratégias de avaliação da qualidade de vida no trabalho: um estudo de caso em agroindústrias. Florianópolis, 2001. 138p. Dissertação (Mestrado em Engenharia de Produção) - PPEP/UFSC, Florianópolis.

DIEESE. Salário Mínimo Nominal e Necessário. Disponível em http://www.dieese.org.br/rel/rac/salminjul05.xml. Acesso em: 09 jul. 2005.

DINIZ, M. G. Fatores Ergonômicos das Condições de Trabalho e a Qualidade de Vida no Trabalho no Setor de Transportes Urbanos Rodoviários: estudo dos casos de Campina Grande e Lisboa. In: ENANPAD, 25. Anais...Campinas: ANPAD, 2001.

DRUCKER, P. Desafios gerenciais para o século XXI. São Paulo: Pioneira, 2000.

Fator Humano e Desempenho. São Paulo: Pioneira, 1991.

DUTRA, J. S. (org). Gestão por competências: um modelo avançado para o gerenciamento de pessoas. São Paulo: Gente, 2001.

A gestão de carreira. In: FLEURY, M.T.L. (org.) As pessoas na organização. São Paulo: Editora Gente, 2002a.

ESCOLA FISK. Disponível em < www.fisk.com.br $>$. Acesso em: 12 mai. 2005. 
FERNANDES, E. C. Tecnologia é essencial. O Jornal de Recursos Humanos. SãoPaulo : Staff Consultores Associados, ano 2, nº 17, 1992

FERREIRA, L.F. A formação em idiomas na Renault: necessidades e novos paradigmas. Artigo baseado na comunicação apresentada no Colóquio Internacional «Pesquisa, ensino de línguas estrangeiras e mercado: encontros e espaços», Universidade de São Paulo, 3-5 novembro. Curitiba, 1998

FISCHER, A. Um resgate conceitual e histórico dos modelos de gestão de pessoas. In: FLEURY, M. T. L. (org.) As pessoas na organização. São Paulo: Editora Gente, 2002.

FISCHER, R. A responsabilidade da cidadania organizacional. In: FLEURY, M. T. L. (org.) As pessoas na organização. São Paulo: Editora Gente, 2002.

FLEURY, A.; FLEURY, M.T. Estratégias Empresariais e Formação de Competências. São Paulo: Editora Atlas, 2001.

FLEURY, M T. A gestão por competências e a estratégia organizacional. In: FLEURY, M. T. L. (org.) As pessoas na organização. São Paulo: Editora Gente, 2002.

, M.T., LACOMBE, B. A Gestão por Competências e a Gestão de Pessoas: um balanço preliminar de resultados de pesquisa no contexto brasileiro. In: Iberoamerican Academy of Management, 2003.

FREITAS H., OLIVEIRA M., SACCOL A.Z., MOSCAROLA. J. O método de pesquisa Survey. Revista de Administração, São Paulo: v. 35 n3, p. 105-112, julho/setembro 2000.

GELVES PEÑA, J. S. O âmago de um espinho adormecido análise da gestão de qualidade de vida no trabalho em um hospital psiquiátrico público. São Paulo, 2000. 165 p. Dissertação (Mestrado em Administração) - FEA/USP.

GOODE, W.J.; HATT, P.K. Métodos em Pesquisa Social. Trad. BORI, C. M. São Paulo: Editora Nacional, 1972.

GORZ, A. Misérias do presente, riqueza do possível. Trad. MONTOIA, A. São Paulo: Annablume, 2004.

GOULART, I.B.; SAMPAIO, J.R. Qualidade de Vida no Trabalho: uma análise da experiência de empresas brasileiras. In.: SAMPAIO, J. R. Qualidade de Vida, Saúde Mental e Psicologia Social: estudos contemporâneos II. São Paulo: Casa do Psicológo, 1999. 
GRABARSCHI, I. V. S. S. Qualidade de Vida no Trabalho e sua Influência na Percepção da Qualidade dos Serviços: Estudo de Caso em Instituição de Nível Superior. Florianópolis, 2001. 115 p. Dissertação (Mestrado em Engenharia de Produção) - PPGEP/UFSC, Florianópolis.

GUEIROS, M. G.; OLIVEIRA, L. M. B. Qualidade de vida no trabalho: um estudo no setor de hotelaria na Região Metropolitana do Recife. In: ENANPAD, 26. Anais...Bahia: ANPAD, 2002.

GUÉRIN, F.; LAVILLE, A.; DANIELlOU, J.; KERGUELEN, A. Compreender o trabalho para transformá-lo: a prática da ergonomia. Trad. INGRATTA, G.M.J.; MAFFEI, M. São Paulo: Edgard Blücher, 2001.

GUIMARÃES, L. Educação Continuada para Professores de Língua Estrangeira (EDUCONLE). In: Congresso Brasileiro de Extensão Universitária, 2. Anais...Minas Gerais: UFMG, 2004.

HACKMAN, R.; OLDHAM, G.R. Development of the Job Diagnostic Survey. Journal of Applied Psychology. Vol. 60, no. 2, 159-170, 1975.

HAIR, J. F.; ANDERSON, R. E.; TATHAM, R. L.; BLACK, W. B. Multivariate Data Analysis. New Jersey: Prentice Hall, 1998.

HIRIGOYEN, M. F. Mal-estar no trabalho: redefinindo o assédio moral. Trad. JANOWITZER, R. Rio de Janeiro: Bertrand Brasil, 2002.

HONORIO, D. E. A Qualidade de vida do operário da construção civil e sua importância na qualidade e produtividades em obras. Florianópolis, 2002. 130 p. Dissertação (Mestrado em Engenharia de Produção) - PPGEP/UFSC, Florianópolis.

HONÓRIO, L. C.; BRAGA, J. O.; MARQUES, A. L. Qualidade de Vida e estresse no trabalho: o caso de uma instituição religiosa. In: ENANPAD, 24. Anais...Florianópolis: ANPAD, 2000.

; MARQUES, A. L.; MELO, M. S. Qualidade de Vida no Trabalho em uma empresa do comércio varejista. In: ENANPAD, 25. Anais...Campinas: ANPAD, 2001.

HOUAISS, A.; VILLAR, M.S.; FRANCO, F.M.M. Dicionário Houaiss da língua portuguesa. Rio de Janeiro: Objetiva, 2004.

HURTADO, L.B.; WUO, L.L.; WAITMAN, M.C. Jornal do Sindicato dos Professores de São Paulo. N.126, out/02. 
HUSE, E.; CUMMINGS, T. Organization development and change. St. Paul: West Publishing Company, 1985.

IBGE. Indicadores IBGE - Pesquisa Mensal de Emprego - Maio/2005. Disponível em <http://www.ibge.gov.br/> Acesso em: 09 jul. 2005.

IIDA, I. Ergonomia: Projeto e Produção. Ed. Edgard Blucher, 1993.

INEP - Instituto Nacional de Estudos e Pesquisas Educacionais Anísio Teixeira. Censo da Educação Superior 2003. Disponível em <http://www.inep.gov.br $>$. Acesso em: 18 nov. 2004.

Instituto Franchising - Disponível em http://www.guiadefranquias.com.br. Acesso em: 19 mai. 2005.

ISKANDAR, J. I. Normas da ABNT comentadas para trabalhos científicos. Curitiba: Juruá, 2004.

KANIKADAN, A. Y. S.; LIMONGI-FRANCA, A. C. Quality of Working Life through the TESOL's Perspectives. In: Peru Tesol Convention-Towards Reflective Teaching, 12, 2004. Anais...Cajamarca: Peru-Tesol, 2004.

KERLINGER, F. N. Metodologia da pesquisa em ciencias sociais: um tratamento conceitual. São Paulo: Epu, 1980.

KILIMNIK, Z. M.; CASTILHO, I. V. Trajetórias e transições de carreira: um estudo longitudinal sobre a qualidade de vida de profissionais assalariados de recursos humanos que experimentaram a passagem para o trabalho autônomo. In: ENANPAD, 26. Anais...Bahia: ANPAD, 2002

LEFFA, V. J. (org) O Professor de Línguas Estrangeiras: Construindo a Profissão. Pelotas: Educat, 2001.

LIMONGI FRANÇA, A. C. Indicadores empresariais de Qualidade de Vida no Trabalho. São Paulo, 1996. 246 p. Tese (Doutorado em Administração) - FEA/USP, São Paulo.

Qualidade de vida no trabalho: conceitos e práticas nas empresas da sociedade pós-industrial. São Paulo: Atlas, 2003.

; RODRIGUES, A.L. Stress e Trabalho: uma abordagem psicossomática. São Paulo: Atlas, 2002. 
LINO, M. M. Qualidade de vida e satisfação profissional de enfermeiras de unidades de terapia intensiva. São Paulo, 2004. 223 p. Tese (Doutorado em Enfermangem) - EE/USP, São Paulo.

LISONDO, H. R. Qualidade dialética: motivação, mudança e resistências. São Paulo, 2000. 363 p. Tese (Doutorado em Engenharia da Produção) - EP/USP.

MAGALHÃES, M. N.; LIMA, A. C. P. Noções de probabilidade e estatística. São Paulo: IME-USP, 2000.

MARASSIA, D. C. C. Liderança e qualidade de vida dentro do trabalho. Ribeiraão Preto, 2000. 135p. Tese (Doutorado em Administração) - FEARP/USP, Ribeirão Preto.

MARCONI, M. A.; LAKATOS, E. M. Fundamentos de Metodologia Científica. São Paulo: Editora Atlas, 2003. Técnicas de Pesquisa. São Paulo: Editora Atlas, 1982.

MARTINS, G. A. Estatística geral e aplicada. São Paulo: Editora Atlas, 2001.

Manual para elaboração de monografias e dissertações. São Paulo: Atlas, 2000.

MATTAR, F. N. Pesquisa de marketing. Edição Compacta. São Paulo: Atlas, 1996.

MEDEIROS, E. G. Análise de Qualidade de Vida no Trabalho: um estudo de caso na área da construção civil. Porto Alegre, 2002. 138p. Dissertação (Mestrado em Administração) - PPGA/UFRGS, Porto Alegre.

MENDES, R. Patologia do Trabalho. Rio de Janeiro: Editora Atheneu, 1995.

Ministério do Meio Ambiente. Disponível em <http://www.mma.gov.br>. Acesso em: 07 nov. 2004.

MinTZBERG, H., AHLSTRAND, B., LAMPEL, G. Safári de Estratégia: um roteiro pela selva do planejamento estratégico. Porto Alegre: Bookman, 2000.

MIRAMONTES, A. Maior impecilho não está na língua, mas no próprio bolso. Folha de São Paulo, São Paulo, 12 dez. 2004. Idiomas, Edição 1. 
MÔNACO, F. F.; GUIMARÃES, V. N. Gestão da Qualidade Total e Qualidade de Vida no Trabalho: o Caso da Gerência de Administração dos Correios. Revista de Administração Contemporânea, v. 4, n. 3, Set./Dez. 2000: 67-88.

MORAES, L. F. R.; PEREIRA, L.Z.; LOPES, H.E.G.; ROCHA, D.B.; FERREIRA, S.A.A.; PORTES, P.C.P. Estresse e Qualidade de Vida no Trabalho na Polícia Militar no Estado de Minas Gerais. In: ENANPAD, 25. Anais...Campinas: ANPAD, 2001.

MOREIRA, D. A. Medida da Produtividade na Empresa Moderna. São Paulo: Pioneira, 1991.

MORGAN, G. As Imagens da Organização. São Paulo: Editora Atlas, 1996.

NOGUEIRA, A. J. F. Gestão estratégica das relações de trabalho. In: FLEURY, M. T. L. (org) As pessoas na organização. São Paulo: Editora Gente, 2002.

NUNES, S. C. Impactos da privatização na qualidade de vida no trabalho uma avaliação sob o ponto de vista do trabalhador. Belo Horizonte, 1999. 286p. Dissertação (Mestrado em Administração) - UFMG, Belo Horizonte.

OLIVEIRA, N. Mudanças Organizacionais e Qualidade de Vida no Trabalho: um estudo comparativo-temporal em unidades do Banco do Brasil S.A. In: ENANPAD, 26. Anais...Bahia: ANPAD, 2002.

OLIVEIRA, R. C. M.; MORAES, L. F. R. Qualidade de Vida no Trabalho: uma análise no contexto de trabalho dos detetives da Polícia Civil Metropolitana de Belo Horizonte. In: ENANPAD, 25. Anais...Campinas: ANPAD, 2001.

PAIVA, K. C. M.; DEUSDEDIT JR, M.; SILVA, M. A. L.; VALENÇA, M. C. A. Situação de Trabalho, Qualidade de Vida e Estresse no Ambiente Acadêmico: comparando professores de instituições pública, privada e confessional. In: ENANPAD, 26. Anais...Bahia: ANPAD, 2002.

PARDINAS, F. Metodología y técnicas de investigación em ciências sociales. México: Siglo XXI Editores, 1969.

PENTEADO, R. Z. Aspectos de qualidade de vida e de subjetividade na promoção da saúde vocal do professor. São Paulo, 2003. 227p. Tese (Doutorado em Saúde Pública) - FSP/USP, São Paulo.

PEREIRA, J. C. R. Análise de dados Qualitativos: Estratégias Metodológicas para as Ciências da Saúde, Humanas e Sociais. São Paulo: Edusp, 2004. 
PEREIRA, M. E. R. O lazer como aspecto alternativo de alívio de tensão, para a equipe de enfermagem. 168 p. Dissertação (Mestrado em Enfermagem) - EERP, Ribeirão Preto, 1997.

PESTANA, M. H.; GAGEIRO, J. N. Análise de dados para ciências sociais: a complementaridade do SPSS. Lisboa: Sílabo, 2003.

PHEASANT, S. Ergonomics, work and health. London: Macmillan Press, 1991.

PICCININI, V. C.; OLIVEIRA, S. R. Flexibilização, Qualidade de Vida e Empregabilidade: $O$ Caso das Cooperativas de Trabalho de Porto Alegre. In: ENANPAD, 26. Anais...Bahia: ANPAD, 2002

PLATERO, L. G. Is the book still on the table? Considerações sobre o ensinoaprendizagem de línguas estrangeiras no ensino médio: uma experiência pedagógica em língua inglesa. São Paulo, 2000. 115p. Dissertação (Mestrado em Educação) FE/USP, São Paulo.

POCHMANN, M. A Destruição Gradual do Estatuto do Trabalho. O Estado de São Paulo, São Paulo em 12/06/97

PORTER, M.E. What's strategy? Harvard Business Review, v.74, nº 6, Nov./Dez, 1996.

PRAHALAD, C.K., HAMEL, G. A Competência Essencial da Organização in MONTGOMERY,C., PORTER, M. Estratégia - a Busca da Vantagem Competitiva. Rio de Janeiro: Campus, 1998.

. Competindo pelo futuro. Rio de Janeiro: Campus, 1995.

ROCHA, S. S. L. Qualidade de vida no trabalho em enfermagem percepção de enfermeiros docentes de uma universidade privada. São Paulo, 2002. 146p. Tese (Doutorado em Enfermagem) - EE/USP, São Paulo.

ROMANZINI, C. D. Qualidade de Vida no Trabalho em Duas Empresas Prestadoras de Serviço de Acesso à Internet na Região de Caxias do Sul. Dissertação (Mestrado Interinstitucional) - PPGA/UCS, Caxias do Sul, 2002.

ROUSSEAU, J. J. Discurso sobre a origem e os fundamentos da desigualdade entre os homens. Trad. Lourdes Santos Machado. São Paulo: Editora Nova Cultural, 2000.

ROY, N.; MERRILL, R.M.; THIBEAULT, S.; PARSA, R.A.; GRAY, S.D.; SMITH, E.M. Prevalence of voice disorders in teachers and the general population. J Speech Lang Hear Res.; 47 (2), p. 285-293, Apr 2004. 
SADY, J. J. Direito do Trabalho do Professor. São Paulo: LTr, 1996.

SANT'ANNA, A. S.; COSTA, R. C. M. M.;MORAES, L. F. R. Qualidade de Vida no Trabalho: uma análise em unidades de ensino básico. In: ENANPAD, 24. Anais...Florianópolis: ANPAD, 2000.

SAUAIA, A. C. A. S. Satisfação e Aprendizagem em Jogos de Empresas: Contribuições para a Educação Gerencial. São Paulo, 1995. 272p. Tese (Doutorado em Administração) - FEA/USP, São Paulo.

SCHEIN, E. H. Career Anchors: discovering your real values. Amsterdam: Pfeiffer, 1993.

SCHMIDT, D. R. C. Qualidade de vida e qualidade de vida no trabalho de profissionais de enfermagem atuantes em unidades do bloco cirúrgico. Ribeirão Preto, 2004. 185p. Dissertação (Mestrado em Enfermagem) - EERP/USP, Ribeirão Preto.

SCHÜTZ, R. A Evolução do Aprendizado de Línguas ao longo de um Século. Disponível em: <http://www.sk.com.br/sk-apren.html>. Acesso em: 03 jan. 2003.

SEBRAE. Disponível em http://www.sebraesp.br. Acesso em: 18 out. 04.

SELTTIZ, C. Métodos de Pesquisa nas Relações Sociais. Trad. LEITE, D. M. São Paulo: Editora Pedagógica e Universitária, 1974.

SENNETT, R. Street and Office: Two Sources of Identity. In: HUTTON W.; GIDDENS, A. On the Edge: Living with Global Capitalism. London: Jonathan Cape, 2000.

SíCOLI, C. R. Qualidade de Vida e fontes de pressão no trabalho do consultor organizacional em BH. Belo Horizonte, 2003. 118p. Dissertação (Mestrado em Administração) - CEPEAD/UFMG, Belo Horizonte.

SILVA, L. V.; ANTUNES, E. D. Influência das Relações Flexíveis de Trabalho na Qualidade de Vida do Trabalhador: a visão de seus atores sociais. In: ENANPAD, 26. Anais...Bahia: ANPAD, 2002.

SILVA, R. T. O teletrabalho e suas influências na qualidade de vida no trabalho. São Paulo, 2004. 185p. Dissertação (Mestrado em Administração) - FEA/USP.

SINPROSP - Sindicato dos Professores de São Paulo. Disponível em <http://www.sinprosp.org.br>. Acesso em: 12 nov. 2004. 
SOUZA, T. M. O gerenciamento no cotidiano de uma unidade de terapia intensiva pediátrica e neonatal e a qualidade de vida no trabalho da equipe de enfermagem. São Paulo, 2003. 126p. Dissertação (Mestrado em Enfermagem) EE/USP.

SPENDER, J.C. Making knowledge the basis of a dynamic theory of the firm. Strategic Management Journal, v.17 (Winter Special issue) 45-62, 1996.

SPSS base 8.0: Applications Guide. Chicago: SPSS Inc., 1998.

STIGLITZ, J. E. Os exuberantes anos 90. São Paulo: Cia. Das Letras, 2003.

SUPER, D. E.; BOHN JR, M.J. Psicologia Ocupacional. Trad. NASCIMENTO, E.; SANTOS, J.F. São Paulo: Atlas, 1972.

TAYLOR, C. R. Qualidade de Vida no Trabalho: resultados a partir da implantação de um modelo de qualidade total, In: In: ENANPAD, 24. Anais...Florianópolis: ANPAD, 2000.

TIPPEE, B. Guarding the language. Oil \& Gas Journal, Tulsa; 28 Out 2002; Vol. 100, Iss. 44; pg. 15, 1 pgs.

TOLFO, S. R.; PICCININI, V. C. As Melhores Empresas para Trabalhar no Brasil e a Qualidade de Vida no Trabalho: Disjunções entre a Teoria e a Prática. Revista de Administração Contemporânea. V. 5 (1), Jan, Fev, Mar e Abr 2001.

VALDEJÃO, R. G. Maioria precisa correr contra o tempo para estudar línguas. Folha de São Paulo, São Paulo, 12 dez. 2004. Idiomas, Edição 1.

WALTON, R. E. Quality of working life: what is it? Sloan Management Review, v.15, n.1, 1973.

WERTHER, W. B.; DAVIS, K. Administração de pessoal e recursos humanos. São Paulo: Mcgraw-Hill do Brasil, 1983.

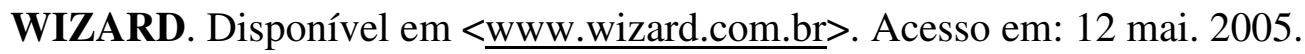

WRIGHT, P.M., DUNFORD, B.B., SNELL, S.A. Human Resources and the resource based view of the firm. Journal of Management. v. 27 (6): 701-721, 2001.

ZAVATtARO, H. A. A qualidade de vida no trabalho de profissionais da área de informática: um estudo exploratório. São Paulo, 1999. 106p. Dissertação (Mestrado em Psicologia) - IP/USP, São Paulo. 
Apêndice A - Carta aos Professores

\section{CARTA PARA OS PROFESSORES}

São Paulo, abril de 2005

Aos

Professores de Inglês

\section{Ref: INFORMAÇÕES SOBRE A PESQUISA DE QUALIDADE DE VIDA NO TRABALHO DOS PROFESSORES DE INGLÊS}

Prezado senhor (a)

Vimos solicitar sua colaboração no levantamento de dados para a pesquisa acadêmica que estamos realizando com o objetivo de identificar as percepções de qualidade de vida no trabalho dos professores de inglês, visando a elaboração da Dissertação de Mestrado a ser apresentada à FEA/USP.

\section{CARACTERÍSTICAS DO ESTUDO:}

O questionário e quem responderá:

O levantamento de campo é composto de um questionário a ser preenchido pelos professores de inglês.

Os professores foram escolhidos através de contatos informais, associações e instituições ligadas aos mesmos.

A análise dos dados:

Os dados e conclusões serão apresentados aos participantes e após defendida a dissertação, será preparada uma síntese dos resultados da pesquisa e enviada a cada respondente.

Confidencialidade:

Todas as informações de identidade serão preservadas. Os dados totais serão apresentados de forma agregada.

Estamos à disposição para esclarecimentos e informações no telefone (011) 9631-7053.

Cordialmente

Profa. Dra. Ana Cristina Limongi-França

(Orientadora)
Andréa Yumi Sugishita Kanikadan

(pesquisadora) 
Apêndice B - Questionário

\section{QUALIDADE DE VIDA NO TRABALHO DOS PROFESSORES DE INGLÊS}

Esta pesquisa tem por objetivo identificar as percepções de qualidade de vida no trabalho dos professores de inglês e está sendo realizada por aluna da pós-graduação da Faculdade de Economia, Administração e Contabilidade da Universidade de São Paulo - FEA/USP. Os resultados desta pesquisa compõem o trabalho que resultará em defesa de dissertação para obtenção de título de mestre da pesquisadora.

É muito importante que você responda todas as questões. Apenas a pesquisadora terá acesso aos dados, garantindo assim a confidencialidade das respostas. Se você tiver interesse em receber os resultados, deixe o seu e-mail ao final.

Desde já agradecemos a sua participação.

Andréa Kanikadan (Pesquisadora) e Ana Cristina Limongi-França (Orientadora)

\section{Como preencher o questionário:}

$1^{\circ}$.) Leia cuidadosamente, responda francamente, mas não demore muito em um item.

$2^{\circ}$.) Não pule item, mesmo que ache difícil responder, assinale apenas a alternativa que se adapte melhor à sua percepção, ou seja, responda o que você ACHA.

$3^{\text {o. }}$ ) Caso dê aulas em mais de um estabelecimento, pense naquele que você dedica a maior parte de seu tempo.

$4^{\circ}$.) Utilize a legenda abaixo:

I_1_I Discordo totalmente.

I_2_I Discordo parcialmente.

I_z_I Discordo pouco.
I_L__I Concordo pouco.

I_5_I Concordo parcialmente.

I_6_I Concordo totalmente.

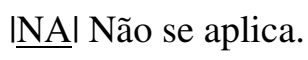

1- A quantidade de horas trabalhadas prejudica meu estado geral de saúde.

2- Os espaços em que trabalho estão adaptados à condição física dos professores.

3- As horas trabalhadas têm afetado minhas atividades dentro e fora da aula.

4- O salário recebido no final do mês é algo que me preocupa.

5- Sinto uma falta de interação com os superiores imediatos.

6- Seria interessante termos mais eventos culturais envolvendo os professores.

7- Considero a flexibilidade de horário como algo positivo, pois posso trabalhar em horários que me permitam realizar outras atividades paralelamente.

8- Realizo muitas atividades ao mesmo tempo.

I_ I 9- Com a segurança de um convênio médico, posso dar melhores aulas.

I_ 10- Se eu tivesse um salário melhor, daria melhores aulas.

I_ I 11- A instituição incentiva à prática de esportes.

I_ 12- Costumo me locomover (fisicamente) de uma instituição a outra, várias vezes ao dia.

I_ I 13- Tenho facilidade de encontrar trabalho nesta área.

I_ 14- O apoio fornecido pela coordenação é fundamental para a minha boa performance em sala de aula.

I_ 1 15- Durante um ano, fico pelo menos, 2 meses sem dar aulas devido às férias dos alunos.

I_ I 16- A coordenação tem pouco tempo para dialogar com os professores, afetando os resultados em sala de aula.

17- Tenho a oportunidade de participar de decisões de planejamento.

18- Não consigo me identificar com a organização. 
I_1_I Discordo totalmente.

I_2_I Discordo parcialmente.

I_z__ Discordo pouco.
I_4__ Concordo pouco.

I_5_I Concordo parcialmente.

I_6_I Concordo totalmente.

INAI Não se aplica.

19- Continuo na organização porque ela fornece alguns benefícios, como vale refeição, cesta básica, ou similar, previdência privada.

L_ 20- O convênio médico oferecido é um diferencial no mercado.

I_ 21- Minha família se orgulha de mim porque sou um professor desta instituição.

I_ 22- Minha família se orgulha de mim porque sou um professor de inglês.

L_ 23- Não me orgulho em trabalhar nesta instituição.

I_ I 24- Existe um grande empenho dos professores em ajudar outros professores.

I_ 25- Temos a oportunidade de participar de congressos, nacionais e/ou internacionais.

I_ I 26- A oportunidade de carreira oferecida pela organização é muito atraente.

I_ 27- A avaliação de desempenho realizada pela coordenação gera resultados positivos.

I_ 28- O pessoal da coordenação entende que uma boa saúde é fundamental para o bom desempenho em sala de aula.

__ 29- O pessoal da coordenação sabe ouvir sempre as sugestões dos professores.

I_ I 30- Tenho um relacionamento satisfatório com minha coordenação.

I_ 31- Recebo apoio para realizar trabalhos junto à comunidade.

I_ 32- A organização fornece financiamento a cursos externos, que complementem a formação do professor.

I_ I3- Tenho a oportunidade de realizar outros cursos de idiomas.

I_ I 34- Existem campanhas visando melhorar os maus hábitos dos funcionários (fumo, álcool, sedentarismo).

I_ 35- Há o respeito às idéias dadas pelos funcionários.

I_ 36- Meus superiores e meus pares criam um ambiente de harmonia e respeito.

I_ 37- A empresa participa de programas voltados para a cidadania.

38- Percebo que os instrumentos utilizados para recrutamento e seleção dos professores satisfazem às exigências dos alunos.

I_ I 39- A instituição nos prepara tecnicamente para lidar com a evolução tecnológica.

I_ 40- Acredito que é fundamental para os funcionários desenvolverem hábitos de vida saudáveis.

I_ I 41- Meu coordenador sempre me ajuda quando tenho problemas que afetam meu estado emocional.

I_ 42- O professor deve apresentar conhecimentos sócio-culturais e competência intercultural.

I_ 43-É fundamental para o professor de inglês conhecer teorias sobre aquisição da linguagem e da língua estrangeira, fonética/fonologia, correntes da lingüística, semiótica e semiologia, análise do discurso, etnografia da comunicação.

44- O professor deve possuir conhecimento de métodos e metodologias para o ensino da língua estrangeira, didática ao conceber atividades pedagógicas; compreensão do público-alvo, de suas necessidades e de suas estratégias de aprendizado, boa dicção.

I_ I 45- O professor de inglês deve apresentar domínio da língua materna e da língua estrangeira do ponto de vista gramatical, semântico e discursivo.

46. Há quanto tempo leciona? (Informe o número de anos):

47. Idade:

48. Sexo: ( )Fem. ( )Masc

anos.

49. Número de dependentes: 
50. Estado Civil:

( ) Casado(a)

( ) Solteiro(a)

( ) Separado(a)

( ) Divorciado(a)

( ) Viúvo(a)

( ) Outro:
51. Faixa salarial:

( ) até $\mathrm{R} \$ 1.000$

( ) $\mathrm{R} \$ 1.001$ a $\mathrm{R} \$ 1.500$

( ) $\mathrm{R} \$ 1.501$ a $\mathrm{R} \$ 2.000$

( ) $\mathrm{R} \$ 2.001$ a $\mathrm{R} \$ 2.500$

( ) $\mathrm{R} \$ 2.501$ a $\mathrm{R} \$ 3.000$

( ) acima de $\mathrm{R} \$ 3.001$

52. Possui outra ocupação além de professor de inglês? Qual?

53. Onde aprendeu o idioma? (Nome da instituição e país)

54. Cidade onde leciona:

55. Faz parte de algum Sindicato ou Associação? Qual?

56. Cursos e Graus em que Leciona (informe o percentual aproximado de tempo dedicado a cada curso, se houver mais de um)

( ) Educação Infantil

( ) $1^{\mathrm{a}}$. a $4^{\mathrm{a}}$. séries - Ensino Fundamental

( ) $5^{\mathrm{a}}$ e $8^{\mathrm{a}}$ séries - Ensino Fundamental

( ) $2^{\circ}$. Grau - Ensino Médio

( ) $3^{\circ}$. Grau - Superior

( ) Cursos Livres (inclui aulas particulares)

( ) Ensino Supletivo

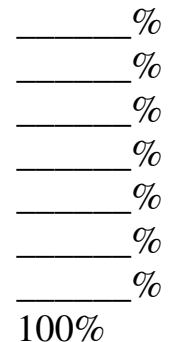

57. Considerando as instituições em que leciona, informe o Regime de Trabalho e quantidade total de horas que leciona por semana:

\begin{tabular}{|l|l|}
\hline \multicolumn{1}{|c|}{ Regime de Trabalho } & Total de horas/semana \\
\hline CLT & \\
\hline Autônomo & \\
\hline Pessoa Jurídica & \\
\hline Trabalho por conta própria & \\
\hline Outro vínculo: & \\
\hline
\end{tabular}

58. Escolaridade:

( ) até segundo grau

( ) superior incompleto

( ) superior completo. Curso:

( ) pós-graduação. Curso:

( ) mestrado. Curso:

( ) doutorado. Curso:

( ) Outras (identifique):

59. Caso queira fazer algum comentário:

60. Poderia indicar o e-mail de mais 2 (dois) professores de inglês?

Obrigada pela sua contribuição, caso queira receber os resultados da pesquisa, deixe seu e-mail: 
Apêndice C - Resultados dos demais questionários que não compuseram a amostra

Professores que dedicam mais de 50\% de seu tempo no Ensino Infantil e Fundamental

Tabela 7.1 - Perfil da amostra de professores do Ensino Infantil e Fundamental

\begin{tabular}{|c|c|c|c|c|c|c|c|c|c|c|c|c|}
\hline & & $\begin{array}{c}\text { Há quanto } \\
\text { tempo } \\
\text { leciona? }\end{array}$ & $\begin{array}{l}\text { Estágio da } \\
\text { vida } \\
\text { vocacional }\end{array}$ & $\begin{array}{l}\text { Qual o } \\
\text { sexo? }\end{array}$ & $\begin{array}{c}\text { No.depen } \\
\text { dentes }\end{array}$ & $\begin{array}{c}\text { Estado } \\
\text { Civil }\end{array}$ & $\begin{array}{c}\text { Faixa } \\
\text { Salarial }\end{array}$ & $\begin{array}{c}\text { Possui } \\
\text { outra } \\
\text { ocupação } \\
?\end{array}$ & $\begin{array}{c}\text { Onde } \\
\text { aprendeu } \\
\text { o idioma? }\end{array}$ & $\begin{array}{l}\text { Cidade } \\
\text { onde } \\
\text { leciona }\end{array}$ & $\begin{array}{c}\text { Faz parte } \\
\text { de algum } \\
\text { sindicato } \\
?\end{array}$ & $\begin{array}{c}\text { Escolarida } \\
\text { de }\end{array}$ \\
\hline & Válidos & 16 & 16 & 16 & 16 & 16 & 16 & 15 & 16 & 16 & 15 & 16 \\
\hline \multicolumn{2}{|c|}{ Não respondidos } & 0 & 0 & 0 & 0 & 0 & 0 & 1 & 0 & 0 & 1 & 0 \\
\hline Média & & 3,62 & 4,87 & 1,12 & 1,06 & 1,31 & 2,87 & 1,60 & 1,87 & 1,43 & 1,33 & 3,62 \\
\hline Mediana & & 3,00 & 5,00 & 1,00 &, 50 & 1,00 & 2,50 & 2,00 & 1,00 & 1,00 & 1,00 & 4,00 \\
\hline Moda & & 2,00 & 5,00 & 1,00 &, 00 & 1,00 & 1,00 & 2,00 & 1,00 & 1,00 & 1,00 & 4,00 \\
\hline $\begin{array}{c}\text { Desvio- } \\
\text { padrão }\end{array}$ & & 1,78 & ,95 & ,34 & 1,23 & ,47 & 1,78 & ,50 & 1,20 & ,51 & ,48 & ,80 \\
\hline Variância & & 3,18 & ,91 & ,11 & 1,52 & ,22 & 3,18 & ,25 & 1,45 & ,26 & ,23 & ,65 \\
\hline Mínimo & & 2,00 & 2,00 & 1,00 &, 00 & 1,00 & 1,00 & 1,00 & 1,00 & 1,00 & 1,00 & 2,00 \\
\hline Máximo & & 7,00 & 6,00 & 2,00 & 3,00 & 2,00 & 6,00 & 2,00 & 5,00 & 2,00 & 2,00 & 5,00 \\
\hline
\end{tabular}

Tabela 7.2 - Classificação por tempo de profissão dos professores do Ensino Infantil e Fundamental

\begin{tabular}{|r|r|r|r|}
\hline $\begin{array}{c}\text { Há quanto } \\
\text { tempo leciona? }\end{array}$ & Freqüência & Percentuall & $\begin{array}{r}\text { Percentual } \\
\text { Acumulado }\end{array}$ \\
\hline de 1 a 5 anos & 6 & 37,5 & 37,5 \\
\hline de 6 a 10 anos & 3 & 18,8 & 56,3 \\
\hline de 11 a 15 anos & 3 & 18,8 & 75,0 \\
\hline de 16 a 20 anos & 1 & 6,3 & 81,3 \\
\hline de 21 a 25 anos & 1 & 6,3 & 87,5 \\
\hline mais de 25 anos & 2 & 12,5 & 100,0 \\
\hline Total & 16 & 100,0 & \\
\hline
\end{tabular}


Tabela 7.3 - Classificação por Idade dos professores do Ensino Infantil e Fundamental

\begin{tabular}{|r|r|r|r|}
\hline \multicolumn{1}{|l|}{ Idade } & Freqüência & Percentual & $\begin{array}{r}\text { Percentual } \\
\text { Acumulado }\end{array}$ \\
\hline $18-21$ & 1 & 6,3 & 6,3 \\
\hline $25-30$ & 2 & 12,5 & 18,8 \\
\hline $31-44$ & 10 & 62,5 & 81,3 \\
\hline $45-64$ & 3 & 18,8 & 100,0 \\
\hline Total & 16 & 100,0 & \\
\hline
\end{tabular}

Tabela 7.4 - Classificação por Sexo dos professores do Ensino Infantil e Fundamental

\begin{tabular}{|r|r|r|r|}
\hline \multicolumn{1}{|l|}{ Sexo } & Freqüência & Percentual & $\begin{array}{r}\text { Percentual } \\
\text { Acumulado }\end{array}$ \\
\hline Feminino & 14 & 87,5 & 87,5 \\
\hline Masculino & 2 & 12,5 & 100,0 \\
\hline Total & 16 & 100,0 & \\
\hline
\end{tabular}

Tabela 7.5 - Classificação por Número de Dependentes dos professores do Ensino Infantil e Fundamental

\begin{tabular}{|r|r|r|r|}
\hline $\begin{array}{r}\text { Número de } \\
\text { dependentes }\end{array}$ & Freqüência & Percentual & $\begin{array}{r}\text { Percentual } \\
\text { Acumulado }\end{array}$ \\
\hline, 00 & 8 & 50,0 & 50,0 \\
\hline 1,00 & 2 & 12,5 & 62,5 \\
\hline 2,00 & 3 & 18,8 & 81,3 \\
\hline 3,00 & 3 & 18,8 & 100,0 \\
\hline Total & 16 & 100,0 & \\
\hline
\end{tabular}


Tabela 7.6 - Classificação por Estado Civil dos professores do Ensino Infantil e Fundamental

\begin{tabular}{|r|r|r|r|}
\hline Estado Civil & Freqüência & Percentual & $\begin{array}{r}\text { Percentual } \\
\text { Acumulado }\end{array}$ \\
\hline Casado(a) & 11 & 68,8 & 68,8 \\
\hline Solteiro(a) & 5 & 31,3 & 100,0 \\
\hline Total & 16 & 100,0 & \\
\hline
\end{tabular}

Tabela 7.7 - Classificação por Faixa Salarial dos professores do Ensino Infantil e Fundamental

\begin{tabular}{|r|r|r|r|}
\hline Faixa Salarial & Freqüência & Percentual & $\begin{array}{r}\text { Percentual } \\
\text { Acumulado }\end{array}$ \\
\hline$<=R \$ 1000$ & 5 & 31,3 & 31,3 \\
\hline$>R \$ 1000$ and $<=R \$ 1500$ & 3 & 18,8 & 50,0 \\
\hline$>R \$ 1500$ and $<=R \$ 2000$ & 2 & 12,5 & 62,5 \\
\hline$>R \$ 2000$ and $<=R \$ 2500$ & 3 & 18,8 & 81,3 \\
\hline$>R \$ 2500$ and $<=3000$ & 1 & 6,3 & 87,5 \\
\hline$>3000$ & 2 & 12,5 & 100,0 \\
\hline Total & 16 & 100,0 & \\
\hline
\end{tabular}

Tabela 7.8 - Percentual de professores do Ensino Infantil e Fundamental que possuem outra ocupação

\begin{tabular}{|r|r|r|r|r|}
\hline $\begin{array}{c}\text { Possui outra } \\
\text { ocupação? }\end{array}$ & Freqüência & Percentual & $\begin{array}{c}\text { Percentual } \\
\text { Válido }\end{array}$ & $\begin{array}{r}\text { Percentual } \\
\text { Acumulado }\end{array}$ \\
\hline sim & 6 & 37,5 & 40,0 & 40,0 \\
\hline não & 9 & 56,3 & 60,0 & 100,0 \\
\hline Total & 15 & 93,8 & 100,0 & \\
\hline $\begin{array}{r}\text { Não } \\
\text { respondidos }\end{array}$ & 1 & 6,3 & & \\
\hline & 16 & 100,0 & & \\
\hline
\end{tabular}


Tabela 7.9 - Classificação por Local de aprendizado do idioma dos professores do Ensino Infantil e Fundamental

\begin{tabular}{|r|r|r|r|}
\hline $\begin{array}{c}\text { Onde aprendeu o } \\
\text { idioma? }\end{array}$ & Freqüência & Percentual & $\begin{array}{r}\text { Percentual } \\
\text { Acumulado }\end{array}$ \\
\hline Brasil & 9 & 56,3 & 56,3 \\
\hline Exterior & 2 & 12,5 & 68,8 \\
\hline Brasil e Exterior & 4 & 25,0 & 93,8 \\
\hline Outros & 1 & 6,3 & 100,0 \\
\hline Total & 16 & 100,0 & \\
\hline
\end{tabular}

Tabela 7.10 - Classificação por cidade onde os professores do Ensino Infantil e Fundamental lecionam

\begin{tabular}{|r|r|r|r|}
\hline $\begin{array}{c}\text { Cidade onde } \\
\text { leciona }\end{array}$ & Freqüência & Percentual & $\begin{array}{r}\text { Percentual } \\
\text { Acumulado }\end{array}$ \\
\hline São Paulo & 9 & 56,3 & 56,3 \\
\hline Outras & 7 & 43,8 & 100,0 \\
\hline Total & 16 & 100,0 & \\
\hline
\end{tabular}

Tabela 7.11 - Distribuição de Frequiência dos professores de Ensino Infantil e Fundamental que fazem parte de sindicato ou associação

\begin{tabular}{|r|r|r|r|r|}
\hline $\begin{array}{c}\text { Faz parte de algum sindicato } \\
\text { ou associação? }\end{array}$ & Freqüência & Percentual & $\begin{array}{c}\text { Percentual } \\
\text { Válido }\end{array}$ & $\begin{array}{r}\text { Percentual } \\
\text { Acumulado }\end{array}$ \\
\hline Sim & 10 & 62,5 & 66,7 & 66,7 \\
\hline Nõo & 5 & 31,3 & 33,3 & 100,0 \\
\hline Não respondidos & 15 & 93,8 & 100,0 & \\
\hline & 1 & 6,3 & & \\
\hline & 16 & 100,0 & & \\
\hline
\end{tabular}


Tabela 7.12 - Classificação por Escolaridade dos Professores do Ensino Infantil e Fundamental

\begin{tabular}{|r|r|r|r|}
\hline Escolaridade & Freqüência & Percentual & $\begin{array}{r}\text { Percentual } \\
\text { Acumulado }\end{array}$ \\
\hline superior incompleto & 1 & 6,3 & 6,3 \\
\hline superior completo & 6 & 37,5 & 43,8 \\
\hline Pós-graduação & 7 & 43,8 & 87,5 \\
\hline Mestrado & 2 & 12,5 & 100,0 \\
\hline Total & 16 & 100,0 & \\
\hline
\end{tabular}


Tabela 7.13 - Medidas de Posição e dispersão das questões 1 a 22 dos professores do Ensino Infantil e Fundamental

\begin{tabular}{|c|c|c|c|c|c|c|c|c|c|c|c|c|c|c|c|c|c|c|c|c|c|c|c|}
\hline & & Q1 & Q2 & Q3 & Q4 & Q5 & Q6 & Q7 & Q8 & Q9 & Q10 & Q11 & Q12 & Q13 & Q14 & Q15 & Q16 & Q17 & Q18 & Q19 & Q20 & Q21 & Q22 \\
\hline $\mathbf{N}$ & Válidos & 16 & 16 & 16 & 16 & 16 & 16 & 13 & 14 & 13 & 15 & 15 & 12 & 16 & 16 & 13 & 15 & 15 & 13 & 12 & 11 & 12 & 16 \\
\hline \multicolumn{2}{|c|}{ Não respondidos } & 0 & 0 & 0 & 0 & 0 & 0 & 3 & 2 & 3 & 1 & 1 & 4 & 0 & 0 & 3 & 1 & 1 & 3 & 4 & 5 & 4 & 0 \\
\hline Média & & 4,43 & 3,68 & 3,75 & 4,81 & 3,37 & 4,81 & 4,84 & 4,50 & 5,46 & 3,20 & 1,60 & 3,16 & 4,75 & 4,62 & 5,07 & 3,46 & 4,73 & 2,69 & 2,08 & 2,81 & 3,41 & 4,25 \\
\hline Mediana & & 5,00 & 4,00 & 4,50 & 5,00 & 4,00 & 5,00 & 5,00 & 5,00 & 6,00 & 4,00 & 1,00 & 3,50 & 5,00 & 5,00 & 6,00 & 4,00 & 5,00 & 2,00 & 1,00 & 1,00 & 4,00 & 4,50 \\
\hline Moda & & 6,00 & 5,00 & 5,00 & 6,00 & 4,00 & 6,00 & 5,00 & 6,00 & 6,00 & 1,00 & 1,00 & 1,00 & 4,00 & 6,00 & 6,00 & 1,00 & 6,00 & 1,00 & 1,00 & 1,00 & 4,00 & 6,00 \\
\hline $\begin{array}{l}\text { Desvio- } \\
\text { padrão }\end{array}$ & & 1,63 & 1,44 & 1,94 & 1,55 & 1,58 & 1,42 & 1,06 & 1,50 & ,87 & 2,11 & 1,40 & 1,94 & ,93 & 1,62 & 1,55 & 1,92 & 1,66 & 1,54 & 1,50 & 2,18 & 1,83 & 1,91 \\
\hline Variânica & & 2,66 & 2,09 & 3,80 & 2,42 & 2,51 & 2,02 & 1,14 & 2,26 & ,76 & 4,45 & 1,97 & 3,78 & ,86 & 2,65 & 2,41 & 3,69 & 2,78 & 2,39 & 2,26 & 4,76 & 3,35 & 3,66 \\
\hline Amplitude & & 5,00 & 4,00 & 5,00 & 5,00 & 4,00 & 5,00 & 3,00 & 4,00 & 2,00 & 5,00 & 4,00 & 5,00 & 3,00 & 5,00 & 5,00 & 5,00 & 5,00 & 4,00 & 4,00 & 5,00 & 5,00 & 5,00 \\
\hline Mínimo & & 1,00 & 1,00 & 1,00 & 1,00 & 1,00 & 1,00 & 3,00 & 2,00 & 4,00 & 1,00 & 1,00 & 1,00 & 3,00 & 1,00 & 1,00 & 1,00 & 1,00 & 1,00 & 1,00 & 1,00 & 1,00 & 1,00 \\
\hline Máximo & & 6,00 & 5,00 & 6,00 & 6,00 & 5,00 & 6,00 & 6,00 & 6,00 & 6,00 & 6,00 & 5,00 & 6,00 & 6,00 & 6,00 & 6,00 & 6,00 & 6,00 & 5,00 & 5,00 & 6,00 & 6,00 & 6,00 \\
\hline \multirow[t]{3}{*}{ Quartis } & 25 & 4,00 & 2,00 & 1,25 & 4,25 & 1,25 & 4,00 & 4,00 & 3,00 & 4,50 & 1,00 & 1,00 & 1,00 & 4,00 & 4,00 & 4,50 & 1,00 & 4,00 & 1,00 & 1,00 & 1,00 & 1,25 & 2,25 \\
\hline & 50 & 5,00 & 4,00 & 4,50 & 5,00 & 4,00 & 5,00 & 5,00 & 5,00 & 6,00 & 4,00 & 1,00 & 3,50 & 5,00 & 5,00 & 6,00 & 4,00 & 5,00 & 2,00 & 1,00 & 1,00 & 4,00 & 4,50 \\
\hline & 75 & 6,00 & 5,00 & 5,00 & 6,00 & 4,75 & 6,00 & 6,00 & 6,00 & 6,00 & 5,00 & 1,00 & 4,75 & 5,75 & 6,00 & 6,00 & 5,00 & 6,00 & 4,00 & 3,75 & 5,00 & 4,75 & 6,00 \\
\hline
\end{tabular}


Tabela 7.14 - Medidas de Posição e dispersão das questões 23 a 45 dos professores do Ensino Infantil e Fundamental

\begin{tabular}{|c|c|c|c|c|c|c|c|c|c|c|c|c|c|c|c|c|c|c|c|c|c|c|c|c|}
\hline & & Q23 & Q24 & Q25 & Q26 & Q27 & Q28 & Q29 & Q30 & Q31 & Q32 & Q33 & Q34 & Q35 & Q36 & Q37 & Q38 & Q39 & Q40 & Q41 & Q42 & Q43 & Q44 & Q45 \\
\hline $\mathbf{N}$ & Válidos & 14 & 16 & 16 & 15 & 15 & 15 & 16 & 16 & 14 & 14 & 14 & 13 & 16 & 16 & 16 & 14 & 16 & 16 & 14 & 16 & 16 & 16 & 16 \\
\hline \multicolumn{2}{|c|}{ Não respondidos } & 2 & 0 & 0 & 1 & 1 & 1 & 0 & 0 & 2 & 2 & 2 & 3 & 0 & 0 & 0 & 2 & 0 & 0 & 2 & 0 & 0 & 0 & 0 \\
\hline Média & & 2,00 & 4,31 & 2,68 & 2,26 & 3,40 & 3,73 & 4,00 & 5,00 & 3,00 & 2,42 & 2,21 & 2,00 & 4,00 & 4,81 & 3,75 & 3,64 & 2,68 & 5,50 & 3,85 & 5,50 & 5,18 & 5,81 & 5,43 \\
\hline Mediana & & 1,00 & 4,50 & 2,00 & 2,00 & 4,00 & 4,00 & 4,00 & 5,00 & 2,00 & 1,00 & 1,00 & 1,00 & 5,00 & 5,00 & 5,00 & 4,00 & 2,00 & 6,00 & 4,00 & 6,00 & 5,50 & 6,00 & 6,00 \\
\hline Moda & & 1,00 & 4,00 & 1,00 & 1,00 & 5,00 & 4,00 & 4,00 & 6,00 & 1,00 & 1,00 & 1,00 & 1,00 & 5,00 & 5,00 & 5,00 & 5,00 & 1,00 & 6,00 & 4,00 & 6,00 & 6,00 & 6,00 & 6,00 \\
\hline $\begin{array}{l}\text { Desvio- } \\
\text { padrão }\end{array}$ & & 1,35 & 1,70 & 1,66 & 1,62 & 1,99 & 1,43 & 1,50 & 1,15 & 2,18 & 2,13 & 2,04 & 1,41 & 1,67 & 1,10 & 1,98 & 1,86 & 1,77 & 1,26 & 1,87 & 1,26 & 1,10 & ,40 & 1,26 \\
\hline Variânica & & 1,84 & 2,89 & 2,76 & 2,63 & 3,97 & 2,06 & 2,26 & 1,33 & 4,76 & 4,57 & 4,18 & 2,00 & 2,80 & 1,22 & 3,93 & 3,47 & 3,16 & 1,60 & 3,51 & 1,60 & 1,22 & ,16 & 1,59 \\
\hline Amplitude & & 4,00 & 5,00 & 4,00 & 4,00 & 5,00 & 5,00 & 5,00 & 3,00 & 5,00 & 5,00 & 5,00 & 3,00 & 5,00 & 3,00 & 5,00 & 5,00 & 5,00 & 5,00 & 5,00 & 5,00 & 4,00 & 1,00 & 5,00 \\
\hline Mínimo & & 1,00 & 1,00 & 1,00 & 1,00 & 1,00 & 1,00 & 1,00 & 3,00 & 1,00 & 1,00 & 1,00 & 1,00 & 1,00 & 3,00 & 1,00 & 1,00 & 1,00 & 1,00 & 1,00 & 1,00 & 2,00 & 5,00 & 1,00 \\
\hline Máximo & & 5,00 & 6,00 & 5,00 & 5,00 & 6,00 & 6,00 & 6,00 & 6,00 & 6,00 & 6,00 & 6,00 & 4,00 & 6,00 & 6,00 & 6,00 & 6,00 & 6,00 & 6,00 & 6,00 & 6,00 & 6,00 & 6,00 & 6,00 \\
\hline \multirow[t]{3}{*}{ Quartis } & 25 & 1,00 & 4,00 & 1,00 & 1,00 & 1,00 & 2,00 & 3,00 & 4,25 & 1,00 & 1,00 & 1,00 & 1,00 & 2,25 & 4,00 & 1,25 & 1,75 & 1,00 & 5,25 & 1,75 & 5,25 & 5,00 & 6,00 & 5,00 \\
\hline & 50 & 1,00 & 4,50 & 2,00 & 2,00 & 4,00 & 4,00 & 4,00 & 5,00 & 2,00 & 1,00 & 1,00 & 1,00 & 5,00 & 5,00 & 5,00 & 4,00 & 2,00 & 6,00 & 4,00 & 6,00 & 5,50 & 6,00 & 6,00 \\
\hline & 75 & 3,00 & 6,00 & 4,00 & 4,00 & 5,00 & 5,00 & 5,00 & 6,00 & 5,25 & 4,50 & 4,25 & 4,00 & 5,00 & 6,00 & 5,00 & 5,00 & 4,75 & 6,00 & 5,25 & 6,00 & 6,00 & 6,00 & 6,00 \\
\hline
\end{tabular}


Professores que dedicam mais de 50\% de seu tempo no Ensino Médio

Tabela 7.15 - Perfil da amostra de professores do Ensino Médio

\begin{tabular}{|c|c|c|c|c|c|c|c|c|c|c|c|c|}
\hline & & $\begin{array}{c}\text { Há } \\
\text { quanto } \\
\text { tempo } \\
\text { leciona? }\end{array}$ & $\begin{array}{c}\text { Estágio da } \\
\text { vida } \\
\text { vocacional }\end{array}$ & $\begin{array}{c}\text { Qual } \\
0 \\
\text { sexo? }\end{array}$ & $\begin{array}{c}\text { Número de } \\
\text { dependentes }\end{array}$ & $\begin{array}{c}\text { Estado } \\
\text { Civil }\end{array}$ & $\begin{array}{c}\text { Faixa } \\
\text { Salarial }\end{array}$ & $\begin{array}{c}\text { Possui } \\
\text { outra } \\
\text { ocupação? }\end{array}$ & $\begin{array}{c}\text { Onde } \\
\text { aprendeu } \\
0 \\
\text { idioma? }\end{array}$ & $\begin{array}{l}\text { Cidade } \\
\text { onde } \\
\text { leciona }\end{array}$ & $\begin{array}{c}\text { Faz parte de } \\
\text { algum } \\
\text { sindicato ou } \\
\text { associação? }\end{array}$ & Escolaridade \\
\hline $\mathbf{N}$ & Válidos & 4 & 4 & 4 & 4 & 4 & 4 & 4 & 4 & 4 & 4 & 4 \\
\hline $\begin{array}{c}\text { Não } \\
\text { respondidos }\end{array}$ & 0 & 0 & 0 & 0 & 0 & 0 & 0 & 0 & 0 & 0 & 0 & 0 \\
\hline Média & & 5,25 & 5,25 & 1,00 & 1,50 & 1,50 & 4,00 & 1,75 & 1,50 & 1,50 & 1,50 & 3,00 \\
\hline Mediana & & 6,00 & 5,50 & 1,00 & 1,50 & 1,50 & 4,00 & 2,00 & 1,00 & 1,50 & 1,50 & 3,00 \\
\hline Moda & & 7,00 & 6,00 & 1,00 &, 00 & 1,00 & 2,00 & 2,00 & 1,00 & 1,00 & 1,00 & 3,00 \\
\hline $\begin{array}{l}\text { Desvio- } \\
\text { padrão }\end{array}$ & & 2,36 & ,95 & , 00 & 1,73 &, 57 & 2,30 &, 50 & 1,00 &, 57 &, 57 & ,81 \\
\hline Variância & & 5,58 & ,91 &, 00 & 3,00 & ,33 & 5,33 & ,25 & 1,00 & ,33 & ,33 & ,66 \\
\hline Mínimo & & 2,00 & 4,00 & 1,00 & , 00 & 1,00 & 2,00 & 1,00 & 1,00 & 1,00 & 1,00 & 2,00 \\
\hline Máximo & & 7,00 & 6,00 & 1,00 & 3,00 & 2,00 & 6,00 & 2,00 & 3,00 & 2,00 & 2,00 & 4,00 \\
\hline
\end{tabular}

Tabela 7.16 - Classificação por tempo de profissão dos professores do Ensino Médio

\begin{tabular}{|r|r|r|r|}
\hline $\begin{array}{c}\text { Quanto tempo } \\
\text { leciona }\end{array}$ & Freqüência & Percentual & $\begin{array}{r}\text { Percentual } \\
\text { Acumulado }\end{array}$ \\
\hline de 1 a 5 anos & 1 & 25,0 & 25,0 \\
\hline de 16 a 20 anos & 1 & 25,0 & 50,0 \\
\hline Mais de 25 anos & 2 & 50,0 & 100,0 \\
\hline Total & 4 & 100,0 & \\
\hline
\end{tabular}


Tabela 7.17 - Classificação por Idade dos professores do Ensino Médio

\begin{tabular}{|r|r|r|r|}
\hline \multicolumn{1}{|l|}{ Idade } & Freqüência & Percentual & $\begin{array}{r}\text { Percentual } \\
\text { Acumulado }\end{array}$ \\
\hline $25-30$ & 1 & 25,0 & 25,0 \\
\hline $31-44$ & 1 & 25,0 & 50,0 \\
\hline $45-64$ & 2 & 50,0 & 100,0 \\
\hline Total & 4 & 100,0 & \\
\hline
\end{tabular}

Tabela 7.18 - Classificação por Sexo dos professores do Ensino Médio

\begin{tabular}{|c|r|r|r|}
\hline $\begin{array}{l}\text { Qual o } \\
\text { sexo? }\end{array}$ & Freqüência & Percentual & $\begin{array}{r}\text { Percentual } \\
\text { Acumulado }\end{array}$ \\
\hline Feminino & 4 & 100,0 & 100,0 \\
\hline
\end{tabular}

Tabela 7.19 - Classificação por Número de Dependentes dos professores do Ensino Médio

\begin{tabular}{|r|r|r|r|}
\hline $\begin{array}{c}\text { Número de } \\
\text { dependentes }\end{array}$ & Freqüência & Percentual & $\begin{array}{r}\text { Percentual } \\
\text { Acumulado }\end{array}$ \\
\hline, 00 & 2 & 50,0 & 50,0 \\
\hline 3,00 & 2 & 50,0 & 100,0 \\
\hline Total & 4 & 100,0 & \\
\hline
\end{tabular}

Tabela 7.20 - Classificação por Estado Civil dos professores do Ensino Médio

\begin{tabular}{|r|r|r|r|}
\hline Estado Civil & Freqüência & Percentual & $\begin{array}{r}\text { Percentual } \\
\text { Acumulado }\end{array}$ \\
\hline Casado(a) & 2 & 50,0 & 50,0 \\
\hline Solteiro(a) & 2 & 50,0 & 100,0 \\
\hline Total & 4 & 100,0 & \\
\hline
\end{tabular}


Tabela 7.21- Classificação por Faixa Salarial dos professores do Ensino Médio

\begin{tabular}{|r|r|r|r|}
\hline \multicolumn{1}{|c|}{ Faixa Salarial } & Freqüência & Percentual & $\begin{array}{r}\text { Percentual } \\
\text { Acumulado }\end{array}$ \\
\hline$>\mathrm{R} \$ 1000$ and $<=R \$ 1500$ & 2 & 50,0 & 50,0 \\
\hline$>3000$ & 2 & 50,0 & 100,0 \\
\hline Total & 4 & 100,0 & \\
\hline
\end{tabular}

Tabela 7.22 - Percentual de professores do Ensino Médio que possuem outra ocupação

\begin{tabular}{|r|r|r|r|}
\hline $\begin{array}{c}\text { Possui outra } \\
\text { ocupação? }\end{array}$ & Freqüência & Percentual & $\begin{array}{r}\text { Percentual } \\
\text { Acumulado }\end{array}$ \\
\hline sim & 1 & 25,0 & 25,0 \\
\hline não & 3 & 75,0 & 100,0 \\
\hline Total & 4 & 100,0 & \\
\hline
\end{tabular}

Tabela 7.23 - Classificação por Local de aprendizado do idioma dos professores do Ensino Médio

\begin{tabular}{|r|r|r|r|}
\hline $\begin{array}{c}\text { Onde aprendeu o } \\
\text { idioma? }\end{array}$ & Freqüência & Percentual & $\begin{array}{r}\text { Percentual } \\
\text { Acumulado }\end{array}$ \\
\hline Brasil & 3 & 75,0 & 75,0 \\
\hline Brasil e Exterior & 1 & 25,0 & 100,0 \\
\hline Total & 4 & 100,0 & \\
\hline
\end{tabular}


Tabela 7.24 - Classificação por cidade onde os professores do Ensino Médio lecionam

\begin{tabular}{|r|r|r|r|}
\hline $\begin{array}{c}\text { Cidade onde } \\
\text { leciona }\end{array}$ & Freqüência & Percentual & $\begin{array}{r}\text { Percentual } \\
\text { Acumulado }\end{array}$ \\
\hline São Paulo & 2 & 50,0 & 50,0 \\
\hline Outras & 2 & 50,0 & 100,0 \\
\hline Total & 4 & 100,0 & \\
\hline
\end{tabular}

Tabela 7.25 - Distribuição de Frequiência dos professores de Ensino Médio que fazem parte de sindicato ou associação

\begin{tabular}{|r|r|r|r|}
\hline $\begin{array}{l}\text { Faz parte de algum sindicato ou } \\
\text { associação? }\end{array}$ & Freqüência & Percentual & $\begin{array}{r}\text { Percentual } \\
\text { Acumulado }\end{array}$ \\
\hline Sim & 2 & 50,0 & 50,0 \\
\hline Não & 2 & 50,0 & 100,0 \\
\hline Total & 4 & 100,0 & \\
\hline
\end{tabular}

Tabela 7.26 - Classificação por Escolaridade dos Professores do Ensino Médio

\begin{tabular}{|r|r|r|r|}
\hline \multicolumn{1}{|c|}{ Escolaridade } & Freqüência & Percentual & $\begin{array}{r}\text { Percentual } \\
\text { Acumulado }\end{array}$ \\
\hline superior incompleto & 1 & 25,0 & 25,0 \\
\hline superior completo & 2 & 50,0 & 75,0 \\
\hline Pós-graduação & 1 & 25,0 & 100,0 \\
\hline Total & 4 & 100,0 & \\
\hline
\end{tabular}


Tabela 7.27 - Medidas de posição e dispersão das questões 1 a 22 dos professores do Ensino Médio

\begin{tabular}{|c|c|c|c|c|c|c|c|c|c|c|c|c|c|c|c|c|c|c|c|c|c|c|c|}
\hline & & Q1 & Q2 & Q3 & Q4 & Q5 & Q6 & Q7 & Q8 & Q9 & Q10 & Q11 & Q12 & Q13 & Q14 & Q15 & Q16 & Q17 & Q18 & Q19 & Q20 & Q21 & Q22 \\
\hline \multicolumn{2}{|c|}{ N Válidos } & 4 & 4 & 4 & 4 & 3 & 4 & 3 & 4 & 3 & 4 & 4 & 2 & 4 & 4 & 4 & 4 & 4 & 4 & 3 & 4 & 3 & 4 \\
\hline \multicolumn{2}{|c|}{ Não respondidos } & 0 & 0 & 0 & 0 & 1 & 0 & 1 & 0 & 1 & 0 & 0 & 2 & 0 & 0 & 0 & 0 & 0 & 0 & 1 & 0 & 1 & 0 \\
\hline Média & & 4,25 & 3,50 & 4,50 & 4,50 & 4,00 & 5,00 & 4,00 & 4,00 & 5,33 & 4,75 & 1,75 & 1,00 & 4,00 & 4,75 & 4,75 & 4,50 & 4,50 & 2,75 & 4,00 & 3,50 & 4,00 & 4,75 \\
\hline Mediana & & 4,50 & 3,50 & 4,50 & 5,00 & 4,00 & 5,00 & 4,00 & 4,00 & 6,00 & 4,50 & 1,00 & 1,00 & 4,00 & 4,50 & 5,00 & 4,50 & 4,50 & 3,00 & 4,00 & 4,00 & 4,00 & 4,50 \\
\hline Moda & & 5,00 & 2,00 & 3,00 & 6,00 & 4,00 & 4,00 & 3,00 & 4,00 & 6,00 & 4,00 & 1,00 & 1,00 & 4,00 & 4,00 & 6,00 & 3,00 & 4,00 & 4,00 & 4,00 & 4,00 & 4,00 & 4,00 \\
\hline $\begin{array}{l}\text { Desvio- } \\
\text { padrão }\end{array}$ & & ,95 & 1,29 & 1,29 & 1,91 &, 00 & 1,15 & 1,00 & 1,63 & 1,15 & ,95 & 1,50 & , 00 & ,81 & ,95 & 1,50 & 1,73 & ,57 & 1,50 &, 00 & 1,73 &, 00 & ,95 \\
\hline Variânica & & ,91 & 1,66 & 1,66 & 3,66 &, 00 & 1,33 & 1,00 & 2,66 & 1,33 & ,91 & 2,25 & , 00 & ,66 & ,91 & 2,25 & 3,00 & ,33 & 2,25 & , 00 & 3,00 & ,00 & ,91 \\
\hline $\begin{array}{c}\text { Amplitud } \\
\mathrm{e}\end{array}$ & & 2,00 & 3,00 & 3,00 & 4,00 & ,00 & 2,00 & 2,00 & 4,00 & 2,00 & 2,00 & 3,00 & ,00 & 2,00 & 2,00 & 3,00 & 3,00 & 1,00 & 3,00 & , 00 & 4,00 & ,00 & 2,00 \\
\hline Mínimo & & 3,00 & 2,00 & 3,00 & 2,00 & 4,00 & 4,00 & 3,00 & 2,00 & 4,00 & 4,00 & 1,00 & 1,00 & 3,00 & 4,00 & 3,00 & 3,00 & 4,00 & 1,00 & 4,00 & 1,00 & 4,00 & 4,00 \\
\hline Máximo & & 5,00 & 5,00 & 6,00 & 6,00 & 4,00 & 6,00 & 5,00 & 6,00 & 6,00 & 6,00 & 4,00 & 1,00 & 5,00 & 6,00 & 6,00 & 6,00 & 5,00 & 4,00 & 4,00 & 5,00 & 4,00 & 6,00 \\
\hline \multirow[t]{3}{*}{ Quartis } & 25 & 3,25 & 2,25 & 3,25 & 2,50 & 4,00 & 4,00 & 3,00 & 2,50 & 4,00 & 4,00 & 1,00 & 1,00 & 3,25 & 4,00 & 3,25 & 3,00 & 4,00 & 1,25 & 4,00 & 1,75 & 4,00 & 4,00 \\
\hline & 50 & 4,50 & 3,50 & 4,50 & 5,00 & 4,00 & 5,00 & 4,00 & 4,00 & 6,00 & 4,50 & 1,00 & 1,00 & 4,00 & 4,50 & 5,00 & 4,50 & 4,50 & 3,00 & 4,00 & 4,00 & 4,00 & 4,50 \\
\hline & 75 & 5,00 & 4,75 & 5,75 & 6,00 & 4,00 & 6,00 & 5,00 & 5,50 & 6,00 & 5,75 & 3,25 & 1,00 & 4,75 & 5,75 & 6,00 & 6,00 & 5,00 & 4,00 & 4,00 & 4,75 & 4,00 & 5,75 \\
\hline
\end{tabular}


Tabela 7.28 - Medidas de posição e dispersão das questões 23 a 45 dos professores do Ensino Médio

\begin{tabular}{|c|c|c|c|c|c|c|c|c|c|c|c|c|c|c|c|c|c|c|c|c|c|c|c|c|}
\hline & & Q23 & Q24 & Q25 & Q26 & Q27 & Q28 & Q29 & Q30 & Q31 & Q32 & Q33 & Q34 & Q35 & Q36 & Q37 & Q38 & Q39 & Q40 & Q41 & Q42 & Q43 & Q44 & Q45 \\
\hline $\mathrm{N}$ & Válidos & 4 & 4 & 3 & 3 & 4 & 4 & 4 & 4 & 4 & 3 & 3 & 4 & 4 & 4 & 4 & 4 & 3 & 4 & 4 & 4 & 4 & 4 & 4 \\
\hline \multicolumn{2}{|c|}{ Não respondidos } & 0 & 0 & 1 & 1 & 0 & 0 & 0 & 0 & 0 & 1 & 1 & 0 & 0 & 0 & 0 & 0 & 1 & 0 & 0 & 0 & 0 & 0 & 0 \\
\hline Média & & 3,00 & 3,25 & 1,33 & 1,00 & 1,25 & 3,25 & 3,50 & 4,25 & 2,50 & 1,00 & 1,00 & 2,00 & 3,50 & 4,00 & 3,25 & 1,75 & 1,00 & 5,75 & 3,00 & 5,75 & 5,25 & 5,75 & 5,75 \\
\hline Mediana & & 3,00 & 4,00 & 1,00 & 1,00 & 1,00 & 3,00 & 3,50 & 4,00 & 2,00 & 1,00 & 1,00 & 1,00 & 3,00 & 4,00 & 3,00 & 1,50 & 1,00 & 6,00 & 2,50 & 6,00 & 5,50 & 6,00 & 6,00 \\
\hline Moda & & 3,00 & 4,00 & 1,00 & 1,00 & 1,00 & 1,00 & 2,00 & 3,00 & 2,00 & 1,00 & 1,00 & 1,00 & 3,00 & 3,00 & 1,00 & 1,00 & 1,00 & 6,00 & 1,00 & 6,00 & 6,00 & 6,00 & 6,00 \\
\hline $\begin{array}{l}\text { Desvio- } \\
\text { padrão }\end{array}$ & & ,81 & 1,50 &, 57 & ,00 &, 50 & 2,21 & 1,29 & 1,50 & 1,73 &, 00 & ,00 & 2,00 & 1,73 & 1,15 & 2,63 & ,95 & , 00 &, 50 & 2,44 &, 50 & ,95 &, 50 &, 50 \\
\hline Variânica & & ,66 & 2,25 & ,33 & ,00 & ,25 & 4,91 & 1,66 & 2,25 & 3,00 & ,00 &, 00 & 4,00 & 3,00 & 1,33 & 6,91 & ,91 &, 00 & ,25 & 6,00 & ,25 & ,91 & ,25 & ,25 \\
\hline Amplitude & & 2,00 & 3,00 & 1,00 & ,00 & 1,00 & 5,00 & 3,00 & 3,00 & 4,00 &, 00 &, 00 & 4,00 & 4,00 & 2,00 & 5,00 & 2,00 &, 00 & 1,00 & 5,00 & 1,00 & 2,00 & 1,00 & 1,00 \\
\hline Mínimo & & 2,00 & 1,00 & 1,00 & 1,00 & 1,00 & 1,00 & 2,00 & 3,00 & 1,00 & 1,00 & 1,00 & 1,00 & 2,00 & 3,00 & 1,00 & 1,00 & 1,00 & 5,00 & 1,00 & 5,00 & 4,00 & 5,00 & 5,00 \\
\hline Máximo & & 4,00 & 4,00 & 2,00 & 1,00 & 2,00 & 6,00 & 5,00 & 6,00 & 5,00 & 1,00 & 1,00 & 5,00 & 6,00 & 5,00 & 6,00 & 3,00 & 1,00 & 6,00 & 6,00 & 6,00 & 6,00 & 6,00 & 6,00 \\
\hline \multirow[t]{3}{*}{ Quartis } & 25 & 2,25 & 1,75 & 1,00 & 1,00 & 1,00 & 1,25 & 2,25 & 3,00 & 1,25 & 1,00 & 1,00 & 1,00 & 2,25 & 3,00 & 1,00 & 1,00 & 1,00 & 5,25 & 1,00 & 5,25 & 4,25 & 5,25 & 5,25 \\
\hline & 50 & 3,00 & 4,00 & 1,00 & 1,00 & 1,00 & 3,00 & 3,50 & 4,00 & 2,00 & 1,00 & 1,00 & 1,00 & 3,00 & 4,00 & 3,00 & 1,50 & 1,00 & 6,00 & 2,50 & 6,00 & 5,50 & 6,00 & 6,00 \\
\hline & 75 & 3,75 & 4,00 & 2,00 & 1,00 & 1,75 & 5,50 & 4,75 & 5,75 & 4,25 & 1,00 & 1,00 & 4,00 & 5,25 & 5,00 & 5,75 & 2,75 & 1,00 & 6,00 & 5,50 & 6,00 & 6,00 & 6,00 & 6,00 \\
\hline
\end{tabular}


Professores que dedicam mais de 50\% de seu tempo no Ensino Superior

Tabela 7.29 - Perfil da amostra de professores do Ensino Superior

\begin{tabular}{|c|c|c|c|c|c|c|c|c|c|c|c|c|}
\hline & & $\begin{array}{c}\text { Há } \\
\text { quanto } \\
\text { tempo } \\
\text { leciona? }\end{array}$ & $\begin{array}{c}\text { Estágio da } \\
\text { vida } \\
\text { vocacional }\end{array}$ & $\begin{array}{c}\text { Qual } \\
\text { o } \\
\text { sexo? }\end{array}$ & $\begin{array}{l}\text { Número de } \\
\text { dependentes }\end{array}$ & $\begin{array}{c}\text { Estado } \\
\text { Civil }\end{array}$ & $\begin{array}{c}\text { Faixa } \\
\text { Salarial }\end{array}$ & $\begin{array}{c}\text { Possui } \\
\text { outra } \\
\text { ocupação? }\end{array}$ & $\begin{array}{c}\text { Onde } \\
\text { aprendeu } \\
\text { o } \\
\text { idioma? }\end{array}$ & $\begin{array}{c}\text { Cidade } \\
\text { onde } \\
\text { lecionas }\end{array}$ & $\begin{array}{c}\text { Faz parte de } \\
\text { algum } \\
\text { sindicato ou } \\
\text { associação? }\end{array}$ & Escolaridade \\
\hline \multicolumn{2}{|c|}{ NVálidos } & 13 & 13 & 13 & 13 & 13 & 12 & 12 & 13 & 13 & 13 & 13 \\
\hline \multicolumn{2}{|c|}{$\begin{array}{r}\text { Não } \\
\text { respondidos }\end{array}$} & 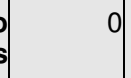 & 0 & 0 & 0 & 0 & 1 & 1 & 0 & 0 & 0 & 0 \\
\hline Média & & 5,00 & 5,30 & 1,15 & 1,15 & 2,07 & 4,83 & 1,58 & 2,15 & 1,92 & 1,30 & 5,46 \\
\hline Mediana & & 5,00 & 5,00 & 1,00 &, 00 & 1,00 & 5,00 & 2,00 & 1,00 & 2,00 & 1,00 & 6,00 \\
\hline Moda & & 5,00 & 5,00 & 1,00 & ,00 & 1,00 & 6,00 & 2,00 & 1,00 & 2,00 & 1,00 & 6,00 \\
\hline $\begin{array}{l}\text { Desvio- } \\
\text { padrão }\end{array}$ & & 1,29 & 63 & ,37 & 1,46 & 1,38 & 1,46 & ,51 & 1,67 & ,27 & ,48 & ,77 \\
\hline Variância & & 1,66 & ,39 & ,14 & 2,14 & 1,91 & 2,15 & ,26 & 2,80 & $\begin{array}{r}7,692 \mathrm{E}- \\
02\end{array}$ & ,23 & ,60 \\
\hline Mínimo & & 3,00 & 4,00 & 1,00 &, 00 & 1,00 & 1,00 & 1,00 & 1,00 & 1,00 & 1,00 & 4,00 \\
\hline Máximo & & 7,00 & 6,00 & 2,00 & 4,00 & 4,00 & 6,00 & 2,00 & 6,00 & 2,00 & 2,00 & 6,00 \\
\hline
\end{tabular}

Tabela 7.30 - Classificação por tempo de profissão dos professores do Ensino Superior

\begin{tabular}{|r|r|r|r|}
\hline $\begin{array}{l}\text { Há quanto tempo } \\
\text { leciona? }\end{array}$ & Freqüência & Percentual & $\begin{array}{r}\text { Percentual } \\
\text { Acumulado }\end{array}$ \\
\hline de 6 a 10 anos & 1 & 7,7 & 7,7 \\
\hline de 11 a 15 anos & 4 & 30,8 & 38,5 \\
\hline de 16 a 20 anos & 5 & 38,5 & 76,9 \\
\hline mais de 25 anos & 3 & 23,1 & 100,0 \\
\hline Total & 13 & 100,0 & \\
\hline
\end{tabular}


Tabela 7.31 - Classificação por Idade dos professores do Ensino Superior

\begin{tabular}{|r|r|r|r|}
\hline \multicolumn{1}{|l|}{ Idade } & Freqüência & Percentual & $\begin{array}{r}\text { Percentual } \\
\text { Acumulado }\end{array}$ \\
\hline $25-30$ & 1 & 7,7 & 7,7 \\
\hline $31-44$ & 7 & 53,8 & 61,5 \\
\hline $45-64$ & 5 & 38,5 & 100,0 \\
\hline Total & 13 & 100,0 & \\
\hline
\end{tabular}

Tabela 7.32 - Classificação por Sexo dos professores do Ensino Superior

\begin{tabular}{|r|r|r|r|}
\hline $\begin{array}{l}\text { Qual o } \\
\text { sexo? }\end{array}$ & Freqüência & Percentual & $\begin{array}{r}\text { Percentual } \\
\text { Acumulado }\end{array}$ \\
\hline Feminino & 11 & 84,6 & 84,6 \\
\hline Masculino & 2 & 15,4 & 100,0 \\
\hline Total & 13 & 100,0 & \\
\hline
\end{tabular}

Tabela 7.33 - Classificação por Número de Dependentes dos professores do Ensino Superior

\begin{tabular}{|r|r|r|r|}
\hline $\begin{array}{c}\text { Número de } \\
\text { dependentes }\end{array}$ & Freqüência & Percentual & $\begin{array}{r}\text { Percentual } \\
\text { Acumulado }\end{array}$ \\
\hline 00 & 7 & 53,8 & 53,8 \\
\hline 1,00 & 1 & 7,7 & 61,5 \\
\hline 2,00 & 2 & 15,4 & 76,9 \\
\hline 3,00 & 2 & 15,4 & 92,3 \\
\hline 4,00 & 1 & 7,7 & 100,0 \\
\hline Total & 13 & 100,0 & \\
\hline
\end{tabular}


Tabela 7.34 - Classificação por Estado Civil dos professores do Ensino Superior

\begin{tabular}{|r|r|r|r|}
\hline Estado Civil & Freqüência & Percentual & $\begin{array}{r}\text { Percentual } \\
\text { Acumulado }\end{array}$ \\
\hline Casado(a) & 7 & 53,8 & 53,8 \\
\hline Solteiro(a) & 2 & 15,4 & 69,2 \\
\hline Divorciado(a) & 4 & 30,8 & 100,0 \\
\hline Total & 13 & 100,0 & \\
\hline
\end{tabular}

Tabela 7.35 - Classificação por Faixa Salarial dos professores do Ensino Superior

\begin{tabular}{|r|r|r|r|r|}
\hline \multicolumn{1}{|c|}{ Faixa Salarial } & Freqüência & Percentual & $\begin{array}{c}\text { Percentual } \\
\text { Válido }\end{array}$ & $\begin{array}{r}\text { Percentual } \\
\text { Acumulado }\end{array}$ \\
\hline$<=R \$ 1000$ & 1 & 7,7 & 8,3 & 8,3 \\
\hline$>\mathrm{R} \$ 2000$ and $<=\mathrm{R} \$ 2500$ & 3 & 23,1 & 25,0 & 33,3 \\
\hline$>\mathrm{R} \$ 2500$ and $<=3000$ & 3 & 23,1 & 25,0 & 58,3 \\
\hline$>3000$ & 5 & 38,5 & 41,7 & 100,0 \\
\hline Total & 12 & 92,3 & 100,0 & \\
\hline Não respondida & 1 & 7,7 & & \\
\hline & 13 & 100,0 & & \\
\hline
\end{tabular}

Tabela 7.36 - Percentual de professores do Ensino Superior que possuem outra ocupação

\begin{tabular}{|r|r|r|r|r|}
\hline Possui outra ocupação? & Freqüência & Percentual & $\begin{array}{c}\text { Percentual } \\
\text { Válido }\end{array}$ & $\begin{array}{c}\text { Percentual } \\
\text { Acumulado }\end{array}$ \\
\hline sim & 5 & 38,5 & 41,7 & 41,7 \\
\hline não & 7 & 53,8 & 58,3 & 100,0 \\
\hline Total & 12 & 92,3 & 100,0 & \\
\hline Não respondida & 1 & 7,7 & & \\
\hline & 13 & 100,0 & & \\
\hline
\end{tabular}


Tabela 7.37 - Classificação por Local de aprendizado do idioma dos professores do Ensino Superior

\begin{tabular}{|r|r|r|r|}
\hline Onde aprendeu o idioma? & Freqüência & Percentual & $\begin{array}{r}\text { Percentual } \\
\text { Acumulado }\end{array}$ \\
\hline Brasil & 7 & 53,8 & 53,8 \\
\hline Exterior & 2 & 15,4 & 69,2 \\
\hline Brasil e Exterior & 2 & 15,4 & 84,6 \\
\hline Outros & 1 & 7,7 & 92,3 \\
\hline Não informou & 1 & 7,7 & 100,0 \\
\hline Total & 13 & 100,0 & \\
\hline
\end{tabular}

Tabela 7.38 - Classificação por cidade onde os professores do Ensino Superior lecionam

\begin{tabular}{|r|r|r|r|}
\hline $\begin{array}{c}\text { Cidade onde } \\
\text { leciona }\end{array}$ & Freqüência & Percentual & $\begin{array}{r}\text { Percentual } \\
\text { Acumulado }\end{array}$ \\
\hline São Paulo & 1 & 7,7 & 7,7 \\
\hline Outras & 12 & 92,3 & 100,0 \\
\hline Total & 13 & 100,0 & \\
\hline
\end{tabular}

Tabela 7.39 - Distribuição de Freqüência dos professores de Ensino Superior que fazem parte de sindicato ou associação

\begin{tabular}{|r|r|r|r|}
\hline $\begin{array}{c}\text { Faz parte de algum sindicato } \\
\text { ou associação? }\end{array}$ & Freqüência & Percentual & $\begin{array}{r}\text { Percentual } \\
\text { Acumulado }\end{array}$ \\
\hline Sim & 9 & 69,2 & 69,2 \\
\hline Não & 4 & 30,8 & 100,0 \\
\hline Total & 13 & 100,0 & \\
\hline
\end{tabular}


Tabela 7.40 - Classificação por Escolaridade dos Professores do Ensino Superior

\begin{tabular}{|r|r|r|r|}
\hline Escolaridade & Freqüência & Percentual & $\begin{array}{r}\text { Percentual } \\
\text { Acumulado }\end{array}$ \\
\hline Pós-graduação & 2 & 15,4 & 15,4 \\
\hline Mestrado & 3 & 23,1 & 38,5 \\
\hline Doutorado & 8 & 61,5 & 100,0 \\
\hline Total & 13 & 100,0 & \\
\hline
\end{tabular}


Tabela 7.41 - Medidas de posição e dispersão das questões 1 a 22 dos professores do Ensino Superior

\begin{tabular}{|c|c|c|c|c|c|c|c|c|c|c|c|c|c|c|c|c|c|c|c|c|c|c|c|}
\hline & & Q1 & Q2 & Q3 & Q4 & Q5 & Q6 & Q7 & Q8 & Q9 & Q10 & Q11 & Q12 & Q13 & Q14 & Q15 & Q16 & Q17 & Q18 & Q19 & Q20 & Q21 & Q22 \\
\hline $\mathrm{N}$ & Válidos & 13 & 12 & 13 & 12 & 13 & 13 & 13 & 13 & 13 & 13 & 12 & 11 & 13 & 12 & 13 & 12 & 13 & 13 & 8 & 8 & 12 & 12 \\
\hline \multicolumn{2}{|c|}{ Não respondidos } & 0 & 1 & 0 & 1 & 0 & 0 & 0 & 0 & 0 & 0 & 1 & 2 & 0 & 1 & 0 & 1 & 0 & 0 & 5 & 5 & 1 & 1 \\
\hline Média & & 3,61 & 4,08 & 4,53 & 4,08 & 2,84 & 4,15 & 5,61 & 5,38 & 4,61 & 3,23 & 1,83 & 3,81 & 4,76 & 4,66 & 5,46 & 3,41 & 4,84 & 1,69 & 1,12 & 2,50 & 4,33 & 5,08 \\
\hline Mediana & & 3,00 & 5,00 & 5,00 & 5,00 & 1,00 & 4,00 & 6,00 & 6,00 & 5,00 & 2,00 & 1,00 & 5,00 & 5,00 & 5,00 & 6,00 & 4,00 & 5,00 & 1,00 & 1,00 & 1,00 & 4,50 & 5,50 \\
\hline Moda & & 2,00 & 5,00 & 6,00 & 6,00 & 1,00 & 6,00 & 6,00 & 6,00 & 6,00 & 1,00 & 1,00 & 1,00 & 6,00 & 6,00 & 6,00 & 4,00 & 5,00 & 1,00 & 1,00 & 1,00 & 4,00 & 6,00 \\
\hline $\begin{array}{l}\text { Desvio- } \\
\text { padrão }\end{array}$ & & 2,06 & 1,78 & 1,80 & 2,02 & 2,19 & 1,81 & ,76 & ,86 & 1,93 & 2,12 & 1,94 & 2,31 & 1,53 & 1,55 & 1,39 & 1,72 & 1,57 & 1,31 & ,35 & 2,13 & 1,77 & 1,08 \\
\hline Variânica & & 4,25 & 3,17 & 3,26 & 4,08 & 4,80 & 3,30 & ,58 & ,75 & 3,75 & 4,52 & 3,78 & 5,36 & 2,35 & 2,42 & 1,93 & 2,99 & 2,47 & 1,73 & , 12 & 4,57 & 3,15 & 1,17 \\
\hline Amplitude & & 5,00 & 5,00 & 4,00 & 5,00 & 5,00 & 5,00 & 2,00 & 3,00 & 5,00 & 5,00 & 5,00 & 5,00 & 4,00 & 5,00 & 5,00 & 5,00 & 5,00 & 4,00 & 1,00 & 5,00 & 5,00 & 3,00 \\
\hline Mínimo & & 1,00 & 1,00 & 2,00 & 1,00 & 1,00 & 1,00 & 4,00 & 3,00 & 1,00 & 1,00 & 1,00 & 1,00 & 2,00 & 1,00 & 1,00 & 1,00 & 1,00 & 1,00 & 1,00 & 1,00 & 1,00 & 3,00 \\
\hline Máximo & & 6,00 & 6,00 & 6,00 & 6,00 & 6,00 & 6,00 & 6,00 & 6,00 & 6,00 & 6,00 & 6,00 & 6,00 & 6,00 & 6,00 & 6,00 & 6,00 & 6,00 & 5,00 & 2,00 & 6,00 & 6,00 & 6,00 \\
\hline \multirow[t]{3}{*}{ Quartis } & 25 & 2,00 & 2,50 & 2,00 & 2,00 & 1,00 & 3,00 & 5,50 & 5,00 & 3,50 & 1,00 & 1,00 & 1,00 & 3,50 & 4,00 & 5,50 & 1,25 & 5,00 & 1,00 & 1,00 & 1,00 & 4,00 & 4,00 \\
\hline & 50 & 3,00 & 5,00 & 5,00 & 5,00 & 1,00 & 4,00 & 6,00 & 6,00 & 5,00 & 2,00 & 1,00 & 5,00 & 5,00 & 5,00 & 6,00 & 4,00 & 5,00 & 1,00 & 1,00 & 1,00 & 4,50 & 5,50 \\
\hline & 75 & 6,00 & 5,00 & 6,00 & 6,00 & 5,00 & 6,00 & 6,00 & 6,00 & 6,00 & 5,50 & 1,00 & 6,00 & 6,00 & 6,00 & 6,00 & 4,75 & 6,00 & 2,00 & 1,00 & 4,75 & 6,00 & 6,00 \\
\hline
\end{tabular}


Tabela 7.42 - Medidas de posição e dispersão das questões 1 a 22 dos professores do Ensino Superior

\begin{tabular}{|c|c|c|c|c|c|c|c|c|c|c|c|c|c|c|c|c|c|c|c|c|c|c|c|c|}
\hline & & Q23 & Q24 & Q25 & Q26 & Q27 & Q28 & Q29 & Q30 & Q31 & Q32 & Q33 & Q34 & Q35 & Q36 & Q37 & Q38 & Q39 & Q40 & Q41 & Q42 & Q43 & Q44 & Q45 \\
\hline $\mathrm{N}$ & Válidos & 13 & 13 & 13 & 12 & 8 & 12 & 13 & 13 & 10 & 12 & 10 & 11 & 12 & 13 & 12 & 11 & 12 & 13 & 10 & 13 & 13 & 13 & 13 \\
\hline \multicolumn{2}{|c|}{ Não respondidos } & 0 & 0 & 0 & 1 & 5 & 1 & 0 & 0 & 3 & 1 & 3 & 2 & 1 & 0 & 1 & 2 & 1 & 0 & 3 & 0 & 0 & 0 & 0 \\
\hline Média & & 1,53 & 3,46 & 3,92 & 2,91 & 4,12 & 4,00 & 4,61 & 5,46 & 3,70 & 2,66 & 2,70 & 1,27 & 4,00 & 4,76 & 4,00 & 3,90 & 3,08 & 5,84 & 4,20 & 5,84 & 5,76 & 6,00 & 5,76 \\
\hline Mediana & & 1,00 & 4,00 & 4,00 & 3,00 & 4,50 & 4,50 & 5,00 & 6,00 & 4,50 & 2,00 & 2,50 & 1,00 & 4,00 & 5,00 & 5,00 & 5,00 & 3,50 & 6,00 & 5,00 & 6,00 & 6,00 & 6,00 & 6,00 \\
\hline Moda & & 1,00 & 4,00 & 4,00 & 1,00 & 5,00 & 1,00 & 5,00 & 6,00 & 1,00 & 1,00 & 1,00 & 1,00 & 4,00 & 5,00 & 5,00 & 5,00 & 1,00 & 6,00 & 5,00 & 6,00 & 6,00 & 6,00 & 6,00 \\
\hline $\begin{array}{l}\text { Desvio- } \\
\text { padrão }\end{array}$ & & 1,12 & 1,56 & 1,38 & 1,88 & 1,55 & 1,95 & 1,60 & ,96 & 2,05 & 1,87 & 1,88 & 90 & 1,34 & 1,23 & 2,00 & 1,86 & 1,83 & 37 & 1,87 & ,55 & ,59 & ,00 & 43 \\
\hline Variânica & & 1,26 & 2,43 & 1,91 & 3,53 & 2,41 & 3,81 & 2,58 & ,93 & 4,23 & 3,51 & 3,56 & ,81 & 1,81 & 1,52 & 4,00 & 3,49 & 3,35 & 14 & 3,51 & ,30 & ,35 & ,00 & 19 \\
\hline Amplitude & & 3,00 & 5,00 & 5,00 & 5,00 & 5,00 & 5,00 & 5,00 & 3,00 & 5,00 & 5,00 & 5,00 & 3,00 & 5,00 & 4,00 & 5,00 & 5,00 & 5,00 & 1,00 & 5,00 & 2,00 & 2,00 & ,00 & 1,00 \\
\hline Mínimo & & 1,00 & 1,00 & 1,00 & 1,00 & 1,00 & 1,00 & 1,00 & 3,00 & 1,00 & 1,00 & 1,00 & 1,00 & 1,00 & 2,00 & 1,00 & 1,00 & 1,00 & 5,00 & 1,00 & 4,00 & 4,00 & 6,00 & 5,00 \\
\hline Máximo & & 4,00 & 6,00 & 6,00 & 6,00 & 6,00 & 6,00 & 6,00 & 6,00 & 6,00 & 6,00 & 6,00 & 4,00 & 6,00 & 6,00 & 6,00 & 6,00 & 6,00 & 6,00 & 6,00 & 6,00 & 6,00 & 6,00 & 6,00 \\
\hline \multirow[t]{3}{*}{ Quartis } & 25 & 1,00 & 2,00 & 3,50 & 1,00 & 3,25 & 1,75 & 4,00 & 5,00 & 1,00 & 1,00 & 1,00 & 1,00 & 4,00 & 4,00 & 1,50 & 2,00 & 1,00 & 6,00 & 2,00 & 6,00 & 6,00 & 6,00 & 5,50 \\
\hline & 50 & 1,00 & 4,00 & 4,00 & 3,00 & 4,50 & 4,50 & 5,00 & 6,00 & 4,50 & 2,00 & 2,50 & 1,00 & 4,00 & 5,00 & 5,00 & 5,00 & 3,50 & 6,00 & 5,00 & 6,00 & 6,00 & 6,00 & 6,00 \\
\hline & 75 & 1,50 & 4,50 & 4,50 & 4,75 & 5,00 & 5,75 & 6,00 & 6,00 & 5,25 & 4,00 & 4,00 & 1,00 & 5,00 & 6,00 & 5,75 & 5,00 & 4,75 & 6,00 & 6,00 & 6,00 & 6,00 & 6,00 & 6,00 \\
\hline
\end{tabular}


Anexo A - Cursos de Graduação por número de matrícula e concluintes

\section{Tabela 9 - Cursos de Graduação Presencial por ordem decrescente do número de matrícula e concluintes - Brasil - 2003}

\begin{tabular}{|c|c|c|c|c|c|c|}
\hline \multirow{2}{*}{ Cursos } & \multicolumn{3}{|c|}{ Matrícula } & \multicolumn{3}{|c|}{ Concluinte } \\
\hline & Número & Percentual & $\begin{array}{l}\text { Percentual } \\
\text { acumulado }\end{array}$ & Número & Percentual & $\begin{array}{l}\text { Percentual } \\
\text { acumulado }\end{array}$ \\
\hline Administração & 564.681 & 14,5 & 14,5 & 63.688 & 12,1 & 12,1 \\
\hline Direito & 508.424 & 13,1 & 27,6 & 64.413 & 12,2 & 24,3 \\
\hline Pedagogia & 373.945 & 9,6 & 37,2 & 65.475 & 12,4 & 36,7 \\
\hline Engenharia & 234.641 & 6,0 & 43,3 & 21.849 & 4,1 & 40,8 \\
\hline Letras & 189.187 & 4,9 & 48,1 & 33.213 & 6.3 & 47,1 \\
\hline Comunicação Social & 174.856 & 4.5 & 52.6 & 21.491 & 4,1 & 51,2 \\
\hline Ciências Contábeis & 157.991 & 4,1 & 56,7 & 21.800 & 4,1 & 55,3 \\
\hline Educação Física & 116.621 & 3,0 & 59,7 & 14.560 & 2.8 & 58,0 \\
\hline Ciência da Computação & 93.167 & 2.4 & 62,1 & 10.435 & 2,0 & 60,0 \\
\hline Enfermagem & 92.134 & 2,4 & 64,4 & 11.252 & 2,1 & 62,1 \\
\hline Psicologia & 90.332 & 2,3 & 66,8 & 14.581 & 2,8 & 64,9 \\
\hline Ciências Biológicas & 89.213 & 2,3 & 69,1 & 13.045 & 2,5 & 67,4 \\
\hline Fisioterapia & 88.508 & 2.3 & 71,3 & 12.615 & 2,4 & 69,8 \\
\hline Turismo & 76.635 & 2,0 & 73,3 & 10.232 & 1,9 & 71,7 \\
\hline Matemática & 70.370 & 1,8 & 75,1 & 11.312 & 2.1 & 73.8 \\
\hline História & 70.336 & 1.8 & 76,9 & 11.708 & 2.2 & 76.1 \\
\hline Economia & 61.584 & 1,6 & 78,5 & 7.761 & 1,5 & 77,5 \\
\hline Medicina & 60.912 & 1,6 & 80,1 & 9.113 & 1,7 & 79,3 \\
\hline Farmácia & 54.297 & 1,4 & 81,5 & 9.703 & 1,8 & 81,1 \\
\hline Sistemas de informação & 52.717 & 1,4 & 82,8 & 2.870 & 0,5 & 81,6 \\
\hline Geografia & 51.656 & 1,3 & 84,2 & 9.124 & 1,7 & 83,4 \\
\hline Odontologia & 46.915 & 1,2 & 85,4 & 9.848 & 1,9 & 85,2 \\
\hline Arquitetura e Urbanismo & 46.206 & 1,2 & 86,6 & 5.590 & 1,1 & 86,3 \\
\hline Ciências & 40.185 & 1,0 & 87.6 & 7.998 & 1.5 & 87,8 \\
\hline Veterinária & 33.424 & 0,9 & 88,5 & 4.303 & 0,8 & 88,6 \\
\hline Nutrição & 32.556 & 0,8 & 89.3 & 4.418 & 0.8 & 89,5 \\
\hline Serviço Social e orientação & 31.986 & 0,8 & 90,1 & 4.679 & 0,9 & 90,3 \\
\hline Design & 29.517 & 0,8 & 90,9 & 2.979 & 0,6 & 90,9 \\
\hline Agronomia & 29.228 & 0,8 & 91,6 & 3.786 & 0,7 & 91,6 \\
\hline Química & 29.052 & 0,7 & 92,4 & 3.626 & 0,7 & 92,3 \\
\hline Processamento de dados & 20.758 & 0,5 & 92,9 & 4.709 & 0,9 & 93,2 \\
\hline Ciências Sociais & 20.401 & 0,5 & 93,4 & 2.653 & 0,5 & 93,7 \\
\hline Fisica e Astronomia & 19.650 & 0.5 & 93,9 & 1.606 & 0,3 & 94,0 \\
\hline Análise de sistemas & 17.155 & 0,4 & 94,4 & 1.821 & 0,3 & 94,3 \\
\hline Secretariado & 16.937 & 0,4 & 94,8 & 2.521 & 0,5 & 94,8 \\
\hline
\end{tabular}




\begin{tabular}{|c|c|c|c|c|c|c|}
\hline \multirow{2}{*}{ Cursos } & \multicolumn{3}{|c|}{ Matrícula } & \multicolumn{3}{|c|}{ Concluinte } \\
\hline & Número & Percentual & $\begin{array}{l}\text { Percentual } \\
\text { acumulado }\end{array}$ & Número & Percentual & $\begin{array}{l}\text { Percentual } \\
\text { acumulado }\end{array}$ \\
\hline Filosofia & 16.814 & 0,4 & 95,2 & 2.326 & 0,4 & 95,3 \\
\hline Artes (Geral) & 15.899 & 0,4 & 95,7 & 3.076 & 0,6 & 95,8 \\
\hline Fonoaudiologia & 13.963 & 0,4 & 96,0 & 2.372 & 0,4 & 96,3 \\
\hline Gereciamento, Comércio e Vendas & 13.667 & 0,4 & 96,4 & 1.258 & 0,2 & 96,5 \\
\hline Relaçöes Internacionais & 10.225 & 0,3 & 96,6 & 945 & 0,2 & 96,7 \\
\hline Produção agrícola e pecuária & 9.324 & 0,2 & 96,9 & 984 & 0,2 & 96,9 \\
\hline Eletrônica & 9.214 & 0,2 & 97,1 & 906 & 0,2 & 97,1 \\
\hline Mecânica & 9.172 & 0,2 & 97,3 & 1.490 & 0,3 & 97,4 \\
\hline Biblioteconomia, documentação e arquivos & 9.078 & 0,2 & 97,6 & 1.418 & 0,3 & 97,6 \\
\hline Belas Artes & 7.723 & 0,2 & 97,8 & 1.015 & 0,2 & 97,8 \\
\hline Hotelaria & 7.281 & 0,2 & 98,0 & 1.271 & 0,2 & 98,1 \\
\hline Terapia e Reabilitação & 7.225 & 0,2 & 98,1 & 1.157 & 0,2 & 98,3 \\
\hline Música & 6.337 & 0,2 & 98,3 & 810 & 0,2 & 98,4 \\
\hline Construção Civil & 5.587 & 0,1 & 98.5 & 721 & 0,1 & 98,6 \\
\hline Estudos Sociais & 5.027 & 0,1 & 98,6 & 1.396 & 0,3 & 98.8 \\
\hline Demais Cursos & 55.058 & 1,4 & 100,0 & 6.180 & 1,2 & 100,0 \\
\hline Total & 3.887 .771 & & & 528.102 & & \\
\hline
\end{tabular}

Fonte : MECINEP/DEAES - CENSO 2003 